\title{
Dynamic Material Flow Analysis of PET, PE, and PP Flows in Europe: Evaluation of the Potentials for Circular Economy
}

\author{
Supporting Information
}

Marie Kampmann Eriksen (postdoc) ${ }^{1 *}$, Kostyantyn Pivnenko (postdoc) ${ }^{1}$, Giorgia Faraca (scientific officer) ${ }^{2}$, Alessio Boldrin (associate professor) ${ }^{1}$, Thomas Fruergaard Astrup (professor) ${ }^{1}$

${ }^{1}$ Department of Environmental Engineering, Technical University of Denmark, Bygningstorvet 115, 2800 Kgs. Lyngby, Denmark

2 European Commission, Joint Research Centre, Edificio EXPO, C/Inca Garcilaso 3, E-41092 Sevilla, Spain

* Address: Bygningstorvet 115, 2800 Kgs. Lyngby, E-mail: maker@env.dtu.dk

- Number of pages: 96

- Number of figures: 12

- Number of tables: 96 


\section{Contents}

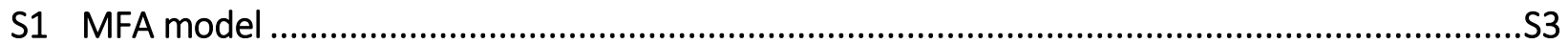

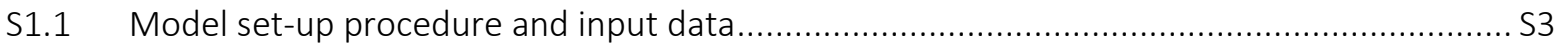

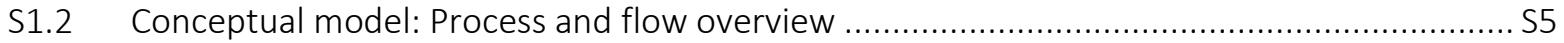

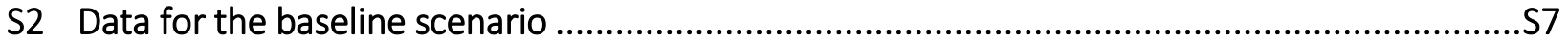

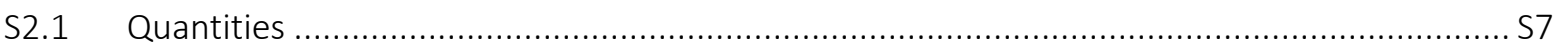

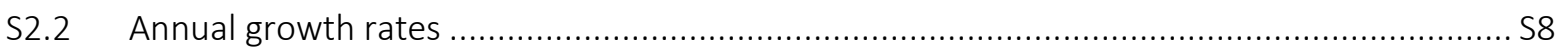

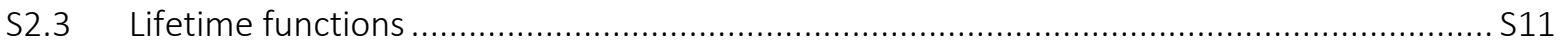

S2.4 Release of plastic from stock from before the modelling period ........................................ S11

S2.5 Modelling the influence of reduced quality/functionality ........................................... 18

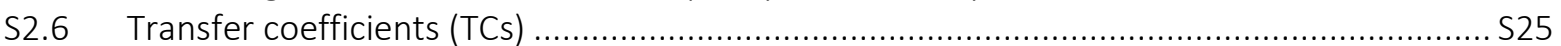

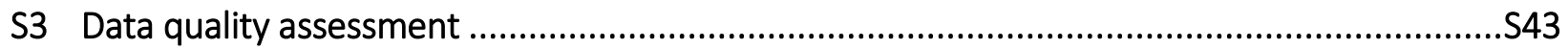

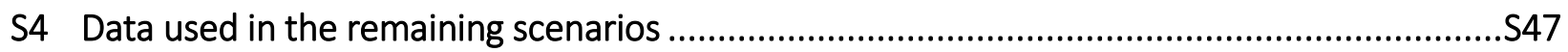

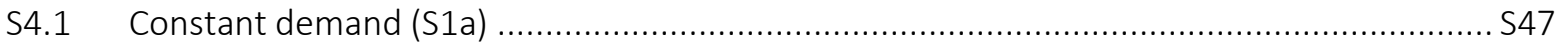

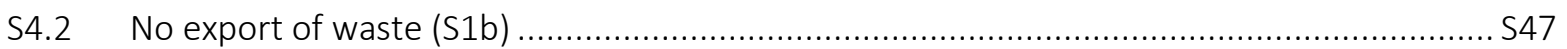

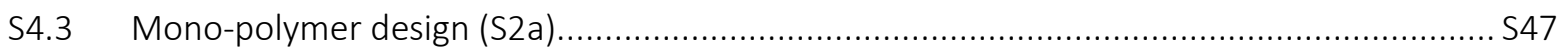

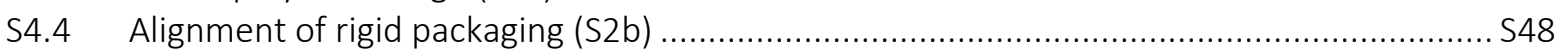

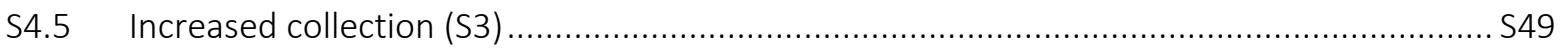

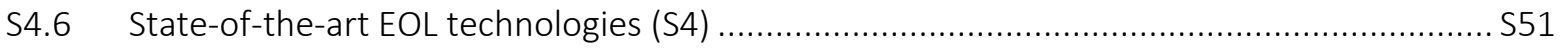

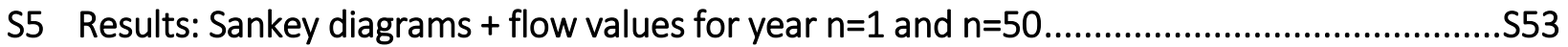

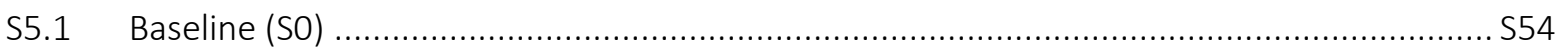

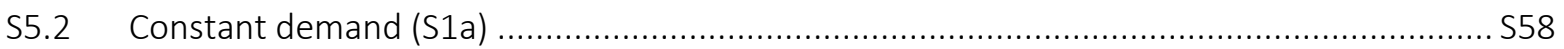

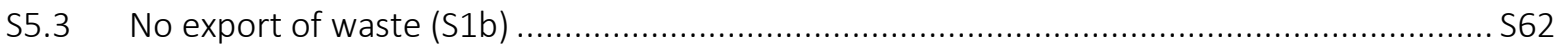

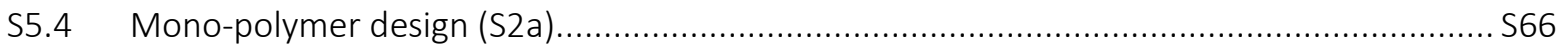

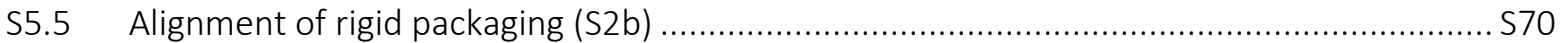

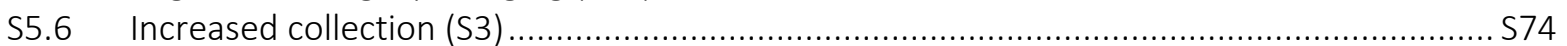

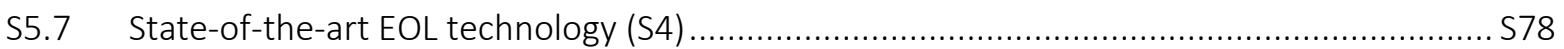

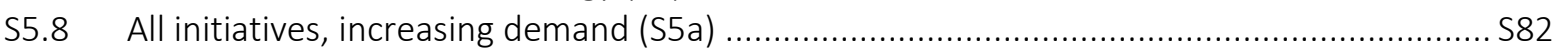

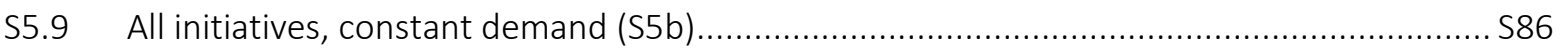

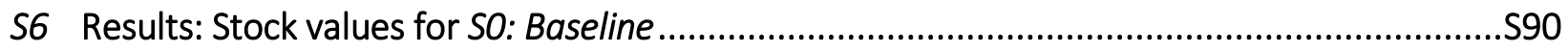

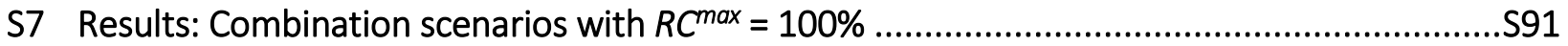

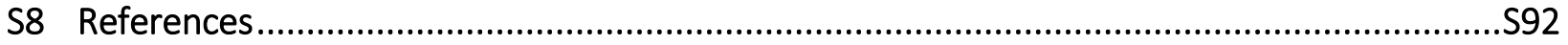




\section{S1 MFA model}

\section{S1.1 Model set-up procedure and input data}

As described in the main manuscript (section 2.1 and 2.2), the system modelling was done, following the below presented procedure:

1. Establish and reconcile a static material flow and stock model, for PET, PE and PP in Europe;

2. Develop a dynamic material flow and stocks model for PET, PE and PP in Europe, by using the transfer coefficients derived from the static model and literature;

3. Adjust the dynamic model to represent realistic scenarios for waste plastic management and assess the potential development of the plastic flows and stocks in Europe.

Figure S1.1 presents an illustration of step 1 and 2, as well as how the static and dynamic system models are linked. On the figure, the input data needed to set-up the static as well as the dynamic model is moreover presented in grey.

As the figure shows, data on European production and import quantities, lifetime functions for all product flows (see list in Table S1.1), as well as transfer coefficients in all processes were used to set-up the static MFA. All of these data represented conditions in 2016.

The static model was extended to a dynamic model by applying growth rates to the overall demand of plastic. The different years were linked, as recycled material from year $n$ was transferred as input material to year $n+1$. The transfer coefficients in all processes were similar to those in the static model and does therefore not change over time. The waste quantities and stock in the use phase where estimated by assigning a given lifetime function to all process flows. Thus, during the start of the dynamic model, nothing is in the stock yet. The stock is built up and the change in stock reaches more stable levels, as the model is run for several years. 
STEP 1:

Static material flow and stock model

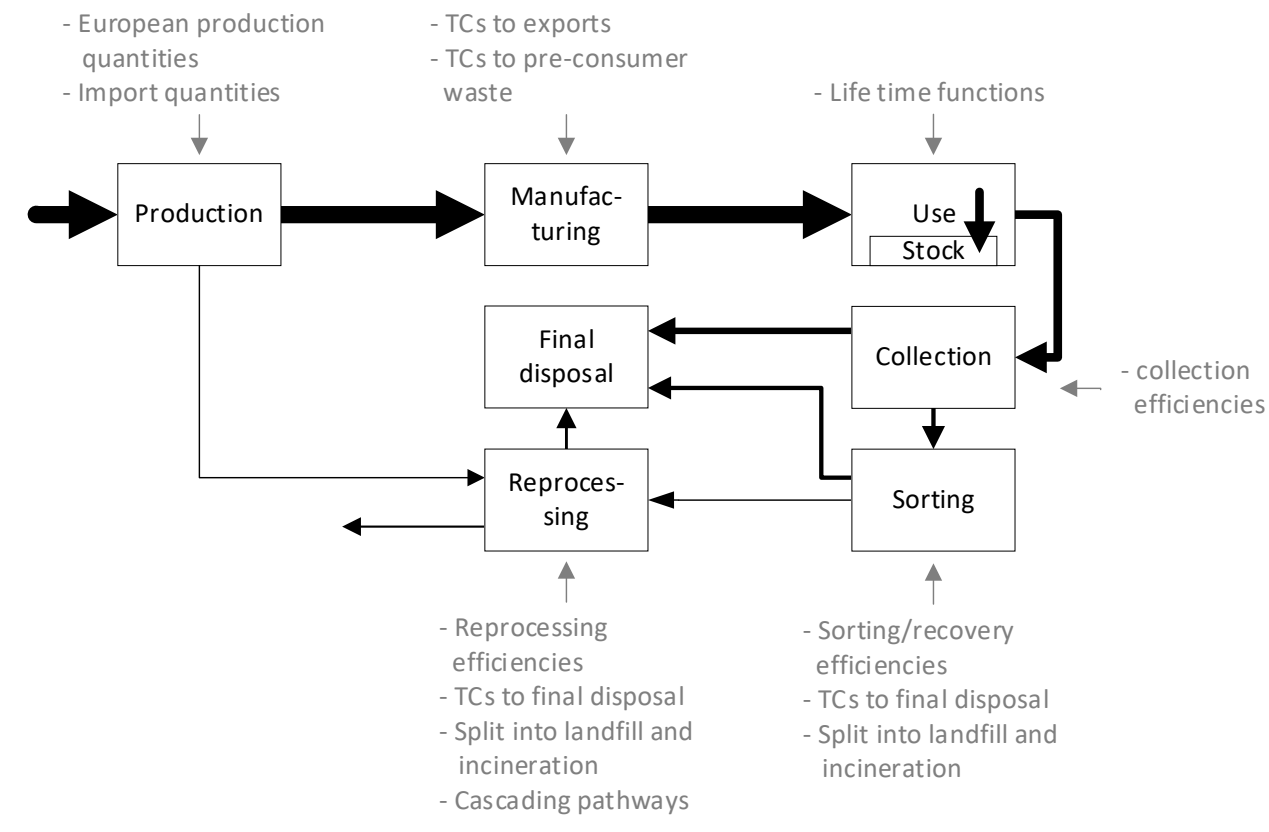

STEP 2:

Dynamic material flow and stocks model

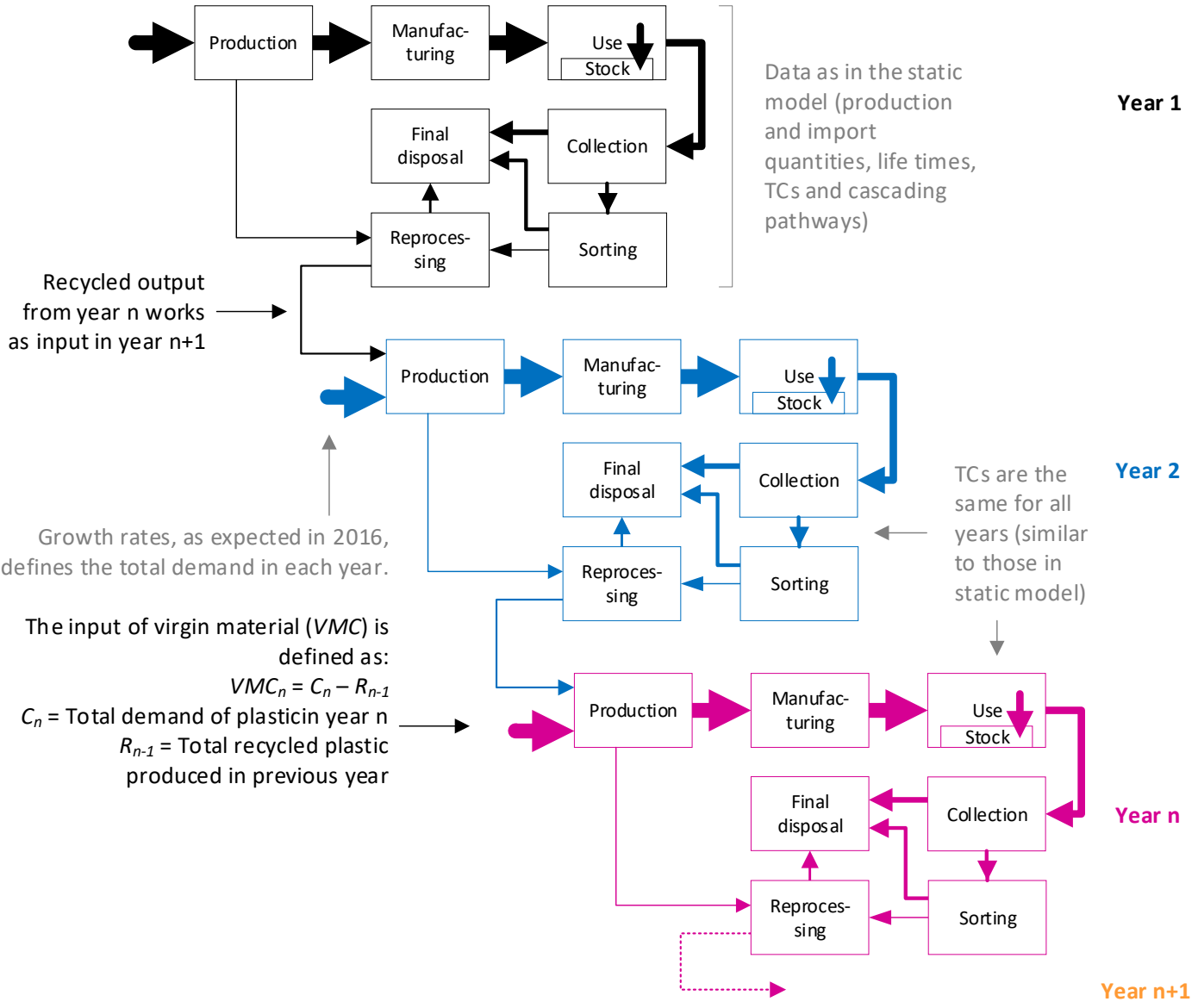

Figure S1.1 Illustration of the modelling set-up procedure of step 1 and 2, with simplified processes and flows (the detailed conceptual model is given in the main manuscript). Input data is presented in grey. TC: transfer coefficient 


\section{S1.2 Conceptual model: Process and flow overview}

The recycled material produced in year $n$ is used as an input material for the production of plastic in year $n+1$, and is assumed to substitute virgin plastic, i.e. reduce the quantities of virgin plastic needed. The only exception is recycled plastic (usually of low quality) assumed not to substitute plastic, but instead other materials, such as wood or metal. This plastic is still modelled as part of the European plastic loop, but is not expected to reduce the amount of virgin plastic used.

In order to sufficiently keep track of differences in chemical requirements for products used in different sectors, as well as differences in mechanical properties of different product types within the same sector, three product flows (bottles, 2D and other rigid products) were defined in each sector, when relevant. The bottle flows include all products that have been produced by blow or rotation molding, including pipes, the 2D flows cover all film, foils and other flat, soft plastic products, whereas other rigids cover the rest, mainly including injection molded products. Additionally, the sector "Others" included the product group "Furniture". Consequently, 20 flows were defined and tracked in the model. These are presented in Table S1.1 and the respective flow names will be used throughout this document. 
Table S1.1 Overview of flows included in the model. The chemical quality of products used in a specific sector, as defined by Eriksen et al. ${ }^{1}$, is indicated.

\begin{tabular}{llll}
\hline Flow name & Sector & Product type & $\begin{array}{l}\text { Legal requirements } \\
\text { to chemical content }\end{array}$ \\
\hline Pac_F_2D & Food packaging & Soft, two-dimensional products & High \\
Pac_F_B & Food packaging & Bottles & High \\
Pac_F_OR & Food packaging & Other rigid products & High \\
Pac_nF_2D & Non-food packaging & Soft, two-dimensional products & Low \\
Pac_nF_B & Non-food packaging & Bottles & Low \\
Pac_nF_OR & Non-food packaging & Other rigid products & Low \\
Electro_2D & Electrical and electronics & Soft, two-dimensional products & Medium \\
Electro_OR & Electrical and electronics & Other rigid products & Medium \\
Agro_2D & Agriculture & Soft, two-dimensional products & Low \\
Agro_P & Agriculture & Pipes & Low \\
Agro_OR & Agriculture & Other rigid products & Low \\
Auto_2D & Automotive & Soft, two-dimensional products & Low \\
Auto_OR & Automotive & Other rigid products \\
BC_2D & Building and construction & Soft, two-dimensional products & Low \\
BC_P & Building and construction & Pipes & Low \\
BC_OR & Building and construction & Other rigid products & Low \\
Fibers & Fibers & Fibers & Low \\
Other_2D & Others & Soft, two-dimensional products & Low* \\
Other_Fu & Others & Low \\
Other_OR & Others & Furniture & Low* \\
\hline *A small share of pharmaceuticals and toys are expected in this category, which according to Eriksen et al. ${ }^{1}$ has a \\
medium chemical quality. However, the amounts are assumed to be minor. & \\
& & &
\end{tabular}




\section{S2 Data for the baseline scenario}

The flows and TC's in the static MFA was estimated by using production data obtained mainly from Kawecki et al. ${ }^{2}$ and PlasticsEurope ${ }^{3}$ and data on waste management pathways and EOL technology performances, based predominantly on Eriksen et al. ${ }^{1}$, Van Eygen et al. ${ }^{4}$, PlasticsEurope ${ }^{5}$, Faraca et al. ${ }^{6}$ and Briassoulis et al. ${ }^{7}$.

This chapter presents all the raw data, applied in SO: Baseline, as well as the sources, from which the data is gathered. The chapter is divided into quantities of specific flows, annual growth rates, lifetime functions, release of plastic from stock produced before the modelling period, modelling of quality related aspects and all applied transfer coefficients (TCS).

\section{S2.1 Quantities}

The production quantities applied in the static model for PET, PE and PP, as well as the distribution into specific product types, are presented in Table S2.1 and Table S2.2.

Table S2.1 Plastic demand in Europe [Kt].

\begin{tabular}{l|c|c|c|l}
\hline Sector & PET & PE & PP & Reference \\
\hline Packaging (food and non-food) & 3666 & 9623 & 4349 & 3 \\
\hline Electronics & 10 & 421 & 483 & 3 \\
\hline Agriculture & 7 & 496 & 608 & 3 \\
\hline Automotive & 2 & 518 & 1299 & 3 \\
\hline Building and construction & 0 & 1749 & 793 & 3 \\
\hline Fibers & 1800 & 0 & 2000 & 2 \\
\hline Others & 17 & 2055 & 2088 & 3 \\
\hline
\end{tabular}


Table S2.2 Plastic demand distribution in the product types. Detailed flow names are provided in Table S1.1.

\begin{tabular}{l|ccc|l}
\hline Flow & PET & PE $^{\mathrm{a}}$ & PP & References \\
\hline Pac_F_2D & 5 & 47 & 18 & 1,2 \\
Pac_F_B & 17 & 4 & 0 & $1,2,8$ \\
Pac_F_OR & 34 & 2 & 29 & $1,2,8$ \\
Pac_nF_2D & 4 & 25 & 20 & $1,2^{2}$ \\
Pac_nF_B & 26 & 18 & 21 & $1,2,8$ \\
Pac_nF_OR & 13 & 1 & 11 & $1,2,8$ \\
Sum & $99^{b}$ & $97^{b}$ & $99^{b}$ & \\
\hline Electro_2D & 0 & 0 & 0 & 9 \\
Electro_OR & 100 & 100 & 100 & 9 \\
Sum & 100 & 100 & 100 & \\
\hline Agro_2D & 0 & 74 & 0 & $7 c, 2 d$ \\
Agro_P & 100 & 16 & 0 & $7 c, 2 d$ \\
Agro_OR & 0 & 12 & 100 & $7 c, 2 d$ \\
Sum & 100 & $102^{b}$ & 100 & \\
\hline BC_2D & 0 & 31 & 0 & 2 \\
BC_P & 0 & 69 & 100 & 2 \\
BC_OR & 100 & 0 & 0 & 2 \\
Sum & 0 & 100 & 100 & \\
\hline Auto_2D & 0 & 0 & 0 & 9 \\
Auto_OR & 100 & 100 & 100 & 9 \\
Sum & 100 & 100 & 100 & \\
\hline Other_2D & 0 & 0 & 0 & 2 \\
Other_Fu & 0 & 12 & 9 & 2 \\
Other_OR & 100 & 85 & 90 & 2 \\
Sum & 100 & $97^{b}$ & $99^{b}$ & \\
\hline
\end{tabular}

a) An estimation of LDPE and HDPE were made and a weighted average, based on production quantities from PlasticsEurope ${ }^{3}$, were made between the two, to estimate total PE.

b) Average data values from Kawecki et al. ${ }^{2}$ do not always sum to 100 , potentially due to number rounding.

c) For PET

d) For PE and PP

\section{S2.2 Annual growth rates}

The annual growth rates (similar to the compound annual growth rate, CAGR) applied for the different flows in SO - Baseline are presented in Table S2.3. The specific growth rates for the individual flows or sectors were based on available literature, as presented in the following sections. Applying annual growth rates will inevitably result in exponential growth over the modelling period. As the individual growth rates are often assumed based on empirical data or predictions on shorter periods than the modelling period of 50 years, it is crucial to compare it to predictions or empirical growth within similar timeframes. 
PlasticsEurope has recorded annual plastic production between 1991 and 2018. In this period the total European plastic production has grown from 24.6 to $61.8 \mathrm{Mt}^{10,11}$, corresponding to an annual growth rate of 3.5\% over 27 years. Moreover, the European Commission expects the European plastic production to double over the next 20 years ${ }^{12}$, similarly corresponding to an annual growth rate of 3.5\%. Finally, Ellen MacArthur Foundation predicts that the global plastic production will grow from $311 \mathrm{Mt}$ in 2014 to 1,124 Mt in $2015^{13}$ - corresponding to an annual growth rate of $3.6 \%$ over 36 years. Thus, agreements exists related to expected annual growth of plastic around 3.5-3.6\%, even over large time periods. As the growth rates assumed for the individual products and sectors lies well around these percentages, they are expected to reasonable predict future growth, in scenario SO: Baseline, representing a business as usual situation.

Table S2.3 Annual growth rates [\%] applied in the model for SO: Baseline.

\begin{tabular}{|c|c|c|c|c|c|c|c|}
\hline \multirow[t]{2}{*}{ Sector } & \multicolumn{3}{|c|}{ Bottles } & \multicolumn{2}{|c|}{$2 \mathrm{D}$} & \multicolumn{2}{|c|}{ Other rigid } \\
\hline & PET & PE & PP & PET & PE \& PP & PET & PE \& PP \\
\hline $\begin{array}{l}\text { Packaging } \\
\text { (food and non-food) } 10,11,14,15,16,17,18\end{array}$ & 2.4 & 4.0 & 3.2 & 2.5 & 3.2 & 3.6 & 3.1 \\
\hline Electrical and electronics ${ }^{10,11,14}$ & \multicolumn{7}{|c|}{2.2} \\
\hline Agriculture ${ }^{10,11,14}$ & \multicolumn{7}{|c|}{3.8} \\
\hline Automotive ${ }^{10,11,19,20,21}$ & \multicolumn{7}{|c|}{4.9} \\
\hline Building and construction $10,11,14$ & \multicolumn{7}{|c|}{2.8} \\
\hline Fibers $^{22}$ & \multicolumn{7}{|c|}{4.8} \\
\hline Others $10,11,13$ & \multicolumn{7}{|c|}{3.55} \\
\hline
\end{tabular}

\section{S2.2.1 Packaging}

Downey predicted growth rates for flexible packaging, PET bottles, thin-walled plastic containers and HDPE bottles, all for food-purposes, of 3.2\%, 4.2\%, 3.1\% and 4\%, respectively, between 2015-2019 in $\mathrm{EU}^{15}$. Moreover, the demand for PET bottles was predicted to grow by $1.9 \%$ per year in Western Europe ${ }^{16}$. The market for PET strapping (modelled as non-food other rigid PET packaging) was forecasted to have an annual growth rate in the period of $2017-2027^{18}$. The European plastic packaging consumption has grown annually with $3.5 \%$ between 2003 and $2018^{10,11}$. Annual growth of $2.4 \%$ was predicted for all plastic packaging between 2014-2025 ${ }^{17}$, whereas Hestin et al. ${ }^{14}$ assumed the annual growth of plastic packaging waste to be $1 \%$ from $2009-2013^{14}$. Based on these numbers, the annual growth rates in Table S2.3 were assumed and applied in the model.

\section{S2.2.2 Electrical and electronics}

According to PlasticsEurope, the production of plastic within Electrical and electronics grew with $0.85 \%$ per year, between 2003 and 2018 ${ }^{10,11}$. However, the annual growth rate for waste electrical and electronic equipment (WEEE) was assumed to be 3.5\% between 2009 and 2013 in a study by Henstin et al. ${ }^{14}$. The data from PlasticsEurope represent actual growth of plastic production, and not waste generation, which data from Hestin et al. represents, which fits the purpose of this study better. On the other hand, where the data from PlasticsEurope represent development in all plastic types, which within Electrical and electronics are dominantly engineered plastic types (not included in this study), the data from Hestins et al. represents growth of only PET, PE-HD, PE-LD, PP, PS and PVC (most of them included in our study), which favors the data from Hestins et al. Thus, an average of $2.2 \%$ was applied in the study. 


\section{S2.2.3 Agriculture}

According to PlasticsEurope, the production of plastic within Agriculture grew with $7.07 \%$ per year, between 2003 and $2018^{10,11}$. However, agricultural plastic waste was assumed to growth annually in EU with $0.5 \%$ between 2009 and 2013, according to Hestin et al. ${ }^{14}$. The data from PlasticsEurope represent actual growth of plastic production, and not waste generation, as data from Hestin et al. represents, which fits the purpose of this study better. On the other hand, where the data from PlasticsEurope represent development in all plastic types, where "other plastics", not included in this study, represent a significant share, the data from Hestins et al. represents growth of only PET, PE-HD, PE-LD, PP, PS and PVC (most of them included in our study), which favors the data from Hestins et al. Thus, an average of 3.8\% was applied in the study.

\section{S2.2.4 Automotive}

Related to the Automotive sector, Plastics Recyclers Europe ${ }^{19}$ report that the use of technical plastic in automotive has double during the last 25 years, resulting in an annual growth rate of $2.8 \%$. On the other hand, according to an analyst in IHS Chemical, the average car will go from containing $200 \mathrm{~kg}$ plastic in 2014 to $350 \mathrm{~kg}$ plastic in $2020^{20}$, corresponding to an annual growth rate of $9.8 \%$ - not accounting for a potential growth in number of cars. Regarding plastic waste available from end-of-life-vehicles, Wrap estimated a growth from $196 \mathrm{kt}$ in 2005 to $252 \mathrm{kt}$ in 2015 in UK ${ }^{21}$, corresponding to an annual growth rate of $2.5 \%$. Finally, according to PlasticsEurope, the production of plastic within Automotive grew with $4.5 \%$ per year, between 2003 and $2018^{10,11}$. The growth rate applied in this study was of $4.9 \%$, found from an average between these values.

\section{S2.2.5 Building and construction}

According to PlasticsEurope, the production of plastic within Building and construction grew with 3.5\% per year, between 2003 and 2018 10,11 . Plastic waste from the Building and construction sector was assumed to growth annually in EU with 2.0\% between 2009 and 2013, according to Hestin et al. ${ }^{14}$. The data from PlasticsEurope represent actual growth of plastic production, and not waste generation, as data from Hestin et al. represents, which fits the purpose of this study better. On the other hand, where the data from PlasticsEurope represent development in all plastic types, where engineered plastic types and "other plastics", not included in this study, represent a considerable share, the data from Hestins et al. represents growth of only PET, PE-HD, PE-LD, PP, PS and PVC (most of them included in our study), which favors the data from Hestins et al. Thus, an average of $2.8 \%$ was applied in the study.

\section{S2.2.6 Fibers}

Statistia reports that the global production of synthetic fibers have grown from $28.4 \mathrm{Mt}$ in 2000 to 66.6 Mt in 2018, corresponding to an annual growth of $4.8 \%^{22}$. Thus, a growth of $4.8 \%$ was applied for the Fiber sector in this study.

\section{S2.2.7 Others}

According to PlasticsEurope, the production of plastic within all Others sectors grew with $1.5 \%$ per year, between 2003 and $2018^{10,11}$. Moreover, Hestins et al. assumed that plastic waste, generated within sectors other than Packaging, Automotive, Electrical \& electronics, Agriculture and Building \& construction, were assumed to growth with $2 \%$ per year in EU, between 2009 and $2013^{14}$. Both studies report a moderate growth. However, both references refer to historical data and does not account for the fact that the Others sector works as a zinc for low quality recycled plastic. Thus, as more and more plastic will get recycled, the authors expect the growth of this sector to increase as well. Thus, a growth rate of 3.55\% was assumed for the Others sector, according to the average prediction from the European Commission and Ellen MacArthur Foundation 


\section{S2.3 Lifetime functions}

As plastic products have lifetimes ranging from weeks (e.g., packaging) to decades (e.g. building materials), normal distributions were assumed to represent the variability of lifetimes for individual plastic products within each sector, as presented in Table S2.4.

Table S2.4 Mean and standard deviation (SD) values in years, used to derive the normal lifetime distributions for plastic products.

\begin{tabular}{l|c|c|l}
\hline Sector & Mean & SD & Reference \\
\hline Packaging (food and non-food) & 0.5 & 0.1 & 23 \\
\hline Electronics & 8 & 2 & 23 \\
\hline Agriculture* & 3 & 1 & 7 \\
\hline Automotive** & 13 & 3 & 23 \\
\hline Building and construction & 35 & 7 & 23 \\
\hline Fibers & 5 & 1.5 & 23 \\
\hline Others & 7 & 3 & Estimate \\
\hline
\end{tabular}

* Weighted average of plastic products used in agriculture. Assuming single use and plastic products used for one season to have the mean of 0.5 years and SD of 0.1 years;

**Assumed to be the same as "Transportation".

\section{S2.4 Release of plastic from stock from before the modelling period}

As presented in Table S2.4, the mean lifetime of products in all sectors other than packaging, was set to be more than 1 year. Consequently, plastic waste from previous years, not within the temporal scope of this study, will still be released from the stock as waste during the modelling period. To account for this, publically available data from PlasticsEurope was used to estimate quantities of plastic waste produced from 1991 to 2015 (a period of 24 years), which is as long back as data is readily available ${ }^{24}$.

The partitioning of European PET, PE and PP into individual sectors was only available from 2009 to 2015. From 1991-2008, the partitioning of each polymer within each sector was assumed equal to that in 2009. Moreover, from 1991 to 2001, the partitioning of the total plastic production into each polymer type, was assumed equal to that in 2003. The partitioning of product types within each sector was assumed equal to that of 2016, used in year 1 of SO: Baseline.

PlasticsEurope does not provide data for synthetic fibers, and thus, the growth rate assumed for fibers, given in Table S2.3, was used to back-calculate until 1991.

In Table S2.5 to Table S2.7, the estimated production from 1991 to 2015 is presented for PET, PE and PP, respectively. Using the lifetime functions presented in section S2.3 and the production data from 1991 to 2015 , release of waste from the stock was calculated for each of the modelling years, as presented in Table S2.8 to Table S2.10, for PET, PE and PP, respectively. The amounts of waste plastic reported in Tables S2.7-2.10 derive from plastic products consumed between 1991 and 2015, before the start of the modelling period $(n=1)$. 
Table S2.5 Estimated production in kt of PET in Europe from 1991 to $2015{ }^{24}$ - used to estimate release from stock within the modelling period. $2 \mathrm{D}$ : two-dimensional soft

\begin{tabular}{|c|c|c|c|c|c|c|c|c|c|c|c|c|c|c|c|c|c|c|c|c|c|c|c|c|c|}
\hline$[\mathrm{kt}]$ & 1991 & 1992 & 1993 & 1994 & 1995 & 1996 & 1997 & 1998 & 1999 & 2000 & 2001 & 2002 & 2003 & 2004 & 2005 & 2006 & 2007 & 2008 & 2009 & 2010 & 2011 & 2012 & 2013 & 2014 & 2015 \\
\hline \multicolumn{26}{|c|}{ 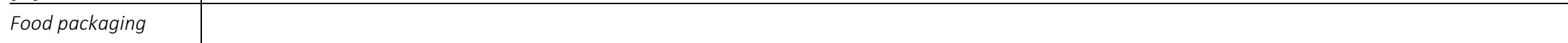 } \\
\hline 2D products & 86 & 88 & 86 & 93 & 92 & 96 & 103 & 108 & 114 & 121 & 127 & 88 & 100 & 105 & 113 & 126 & 173 & 170 & 180 & 139 & 153 & 149 & 160 & 167 & 174 \\
\hline Bottles & 293 & 299 & 293 & 315 & 313 & 325 & 350 & 367 & 387 & 413 & 431 & 299 & 342 & 357 & 384 & 430 & 589 & 577 & 612 & 473 & 519 & 507 & 543 & 569 & 591 \\
\hline Other rigid products & 585 & 597 & 585 & 631 & 626 & 650 & 700 & 733 & 773 & 826 & 862 & 598 & 683 & 714 & 768 & 860 & 1178 & 1154 & 1224 & 947 & 1039 & 1014 & 1086 & 1138 & 1183 \\
\hline \multicolumn{26}{|l|}{ Non-food packaging } \\
\hline 2D products & 69 & 70 & 69 & 74 & 74 & 76 & 82 & 86 & 91 & 97 & 101 & 70 & 80 & 84 & 90 & 101 & 139 & 136 & 144 & 111 & 122 & 119 & 128 & 134 & 139 \\
\hline Bottles & 448 & 457 & 448 & 482 & 479 & 497 & 535 & 561 & 591 & 632 & 659 & 458 & 523 & 546 & 588 & 658 & 901 & 883 & 936 & 724 & 794 & 776 & 831 & 870 & 905 \\
\hline Other rigid products & 224 & 228 & 224 & 241 & 239 & 248 & 268 & 280 & 296 & 316 & 329 & 229 & 261 & 273 & 294 & 329 & 450 & 441 & 468 & 362 & 397 & 388 & 415 & 435 & 452 \\
\hline Electrical\&electronics & 0 & 0 & 0 & 0 & 0 & 0 & 0 & 0 & 0 & 0 & 0 & 0 & 0 & 0 & 0 & 0 & 0 & 0 & 0 & 0 & 0 & 0 & 0 & 0 & 0 \\
\hline \multicolumn{26}{|l|}{ Building\&construction } \\
\hline 2D products & 0 & 0 & 0 & 0 & 0 & 0 & 0 & 0 & 0 & 0 & 0 & 0 & 0 & 0 & 0 & 0 & 0 & 0 & 0 & 0 & 0 & 0 & 0 & 0 & 0 \\
\hline Pipes & 0 & 0 & 0 & 0 & 0 & 0 & 0 & 0 & 0 & 0 & 0 & 0 & 0 & 0 & 0 & 0 & 0 & 0 & 0 & 0 & 0 & 0 & 0 & 0 & 0 \\
\hline Other rigid products & 0 & 0 & 0 & 0 & 0 & 0 & 0 & 0 & 0 & 0 & 0 & 0 & 0 & 0 & 0 & 0 & 0 & 0 & 0 & 0 & 0 & 0 & 0 & 0 & 0 \\
\hline \multicolumn{26}{|l|}{ Agriculture } \\
\hline 2D products & 0 & 0 & 0 & 0 & 0 & 0 & 0 & 0 & 0 & 0 & 0 & 0 & 0 & 0 & 0 & 0 & 0 & 0 & 0 & 0 & 0 & 0 & 0 & 0 & 0 \\
\hline Pipes & 0 & 0 & 0 & 0 & 0 & 0 & 0 & 0 & 0 & 0 & 0 & 0 & 0 & 0 & 0 & 0 & 0 & 0 & 0 & 0 & 0 & 0 & 0 & 0 & 0 \\
\hline Other rigid products & 0 & 0 & 0 & 0 & 0 & 0 & 0 & 0 & 0 & 0 & 0 & 0 & 0 & 0 & 0 & 0 & 0 & 0 & 0 & 0 & 0 & 0 & 0 & 0 & 0 \\
\hline Fibers & 839 & 879 & 922 & 966 & 1012 & 1061 & 1112 & 1165 & 1221 & 1280 & 1341 & 1405 & 1473 & 1543 & 1618 & 1695 & 1777 & 1862 & 1951 & 2045 & 2143 & 2246 & 2354 & 2467 & 2585 \\
\hline \multicolumn{26}{|l|}{ Other } \\
\hline 2D products & 0 & 0 & 0 & 0 & 0 & 0 & 0 & 0 & 0 & 0 & 0 & 0 & 0 & 0 & 0 & 0 & 0 & 0 & 0 & 0 & 0 & 0 & 0 & 0 & 0 \\
\hline Furniture & 0 & 0 & 0 & 0 & 0 & 0 & 0 & 0 & 0 & 0 & 0 & 0 & 0 & 0 & 0 & 0 & 0 & 0 & 0 & 0 & 0 & 0 & 0 & 0 & 0 \\
\hline Other rigid products & 526 & 553 & 581 & 610 & 641 & 673 & 707 & 743 & 780 & 819 & 861 & 904 & 950 & 998 & 1048 & 1101 & 1156 & 1214 & 1276 & 1340 & 1408 & 1478 & 1553 & 1631 & 1714 \\
\hline
\end{tabular}


Table S2.6 Estimated production in kt of PE in Europe from 1991 to $2015^{24}$ - used to estimate release from stock within the modelling period. 2D: two-dimensional soft

\begin{tabular}{|c|c|c|c|c|c|c|c|c|c|c|c|c|c|c|c|c|c|c|c|c|c|c|c|c|c|}
\hline [kt] & 1991 & 1992 & 1993 & 1994 & 1995 & 1996 & 1997 & 1998 & 1999 & 2000 & 2001 & 2002 & 2003 & 2004 & 2005 & 2006 & 2007 & 2008 & 2009 & 2010 & 2011 & 2012 & 2013 & 2014 & 2015 \\
\hline \multicolumn{26}{|c|}{$e_{1}$} \\
\hline 2D products & 2279 & 2326 & 2279 & 2455 & 2437 & 2529 & 2724 & 2854 & 3011 & 3215 & 3354 & 3706 & 3804 & 3906 & 3907 & 3891 & 4586 & 4339 & 4169 & 3939 & 4470 & 4345 & 4425 & 4523 & 4316 \\
\hline Bottles & 194 & 198 & 194 & 209 & 207 & 215 & 232 & 243 & 256 & 274 & 285 & 315 & 324 & 332 & 333 & 331 & 390 & 369 & 355 & 335 & 380 & 370 & 377 & 385 & 367 \\
\hline Other rigid products & 97 & 99 & 97 & 104 & 104 & 108 & 116 & 121 & 128 & 137 & 143 & 158 & 162 & 166 & 166 & 166 & 195 & 185 & 177 & 168 & 190 & 185 & 188 & 192 & 184 \\
\hline \multicolumn{26}{|l|}{ Non-food packaging } \\
\hline 2D products & 1212 & 1237 & 1212 & 1306 & 1296 & 1345 & 1449 & 1518 & 1602 & 1710 & 1784 & 1971 & 2023 & 2078 & 2078 & 2070 & 2440 & 2308 & 2218 & 2095 & 2378 & 2311 & 2354 & 2406 & 2296 \\
\hline Bottles & 873 & 891 & 873 & 940 & 933 & 969 & 1043 & 1093 & 1153 & 1231 & 1285 & 1419 & 1457 & 1496 & 1496 & 1490 & 1756 & 1662 & 1597 & 1509 & 1712 & 1664 & 1695 & 1732 & 1653 \\
\hline Other rigid products & 48 & 49 & 48 & 52 & 52 & 54 & 58 & 61 & 64 & 68 & 71 & 79 & 81 & 83 & 83 & 83 & 98 & 92 & 89 & 84 & 95 & 92 & 94 & 96 & 92 \\
\hline Electrical\&electronics & 158 & 161 & 158 & 170 & 169 & 175 & 188 & 197 & 208 & 222 & 232 & 256 & 263 & 270 & 270 & 269 & 317 & 300 & 289 & 364 & 285 & 311 & 316 & 323 & 397 \\
\hline \multicolumn{26}{|l|}{ Building\&construction } \\
\hline $2 D$ products & 189 & 192 & 189 & 203 & 202 & 209 & 225 & 236 & 249 & 266 & 277 & 307 & 315 & 323 & 323 & 322 & 379 & 359 & 345 & 481 & 426 & 477 & 486 & 496 & 536 \\
\hline Pipes & 420 & 428 & 420 & 452 & 449 & 466 & 502 & 525 & 554 & 592 & 618 & 682 & 700 & 719 & 719 & 716 & 844 & 799 & 768 & 1072 & 949 & 1061 & 1081 & 1105 & 1193 \\
\hline Other rigid products & 0 & 0 & 0 & 0 & 0 & 0 & 0 & 0 & 0 & 0 & 0 & 0 & 0 & 0 & 0 & 0 & 0 & 0 & 0 & 0 & 0 & 0 & 0 & 0 & 0 \\
\hline \multicolumn{26}{|l|}{ Agriculture } \\
\hline 2D products & 203 & 208 & 203 & 219 & 217 & 226 & 243 & 255 & 269 & 287 & 299 & 331 & 339 & 349 & 349 & 347 & 409 & 387 & 372 & 409 & 296 & 288 & 287 & 293 & 378 \\
\hline Pipes & 44 & 45 & 44 & 47 & 47 & 49 & 53 & 55 & 58 & 62 & 65 & 72 & 73 & 75 & 75 & 75 & 89 & 84 & 80 & 88 & 64 & 62 & 62 & 63 & 82 \\
\hline Other rigid products & 33 & 34 & 33 & 36 & 35 & 37 & 39 & 41 & 44 & 47 & 49 & 54 & 55 & 57 & 57 & 56 & 66 & 63 & 60 & 66 & 48 & 47 & 46 & 48 & 61 \\
\hline Fibers & 321 & 336 & 352 & 369 & 387 & 405 & 425 & 445 & 466 & 489 & 512 & 537 & 563 & 590 & 618 & 648 & 679 & 711 & 746 & 781 & 819 & 858 & 899 & 942 & 988 \\
\hline \multicolumn{26}{|l|}{ Other } \\
\hline 2D products & 137 & 139 & 137 & 147 & 146 & 152 & 163 & 171 & 180 & 193 & 201 & 222 & 228 & 234 & 234 & 233 & 275 & 260 & 250 & 274 & 199 & 194 & 192 & 197 & 254 \\
\hline Furniture & 968 & 987 & 968 & 1042 & 1034 & 1074 & 1156 & 1211 & 1278 & 1365 & 1424 & 1573 & 1615 & 1658 & 1659 & 1652 & 1947 & 1842 & 1770 & 1943 & 1406 & 1372 & 1363 & 1393 & 1799 \\
\hline Other rigid products & 0 & 0 & 0 & 0 & 0 & 0 & 0 & 0 & 0 & 0 & 0 & 0 & 0 & 0 & 0 & 0 & 0 & 0 & 0 & 0 & 0 & 0 & 0 & 0 & 0 \\
\hline
\end{tabular}


Table S2.7 Estimated production in kt of PP in Europe from 1991 to $2015^{24}$ - used to estimate release from stock within the modelling period. 2D: two-dimensional soft

\begin{tabular}{|c|c|c|c|c|c|c|c|c|c|c|c|c|c|c|c|c|c|c|c|c|c|c|c|c|c|}
\hline$[k t]$ & 991 & 1992 & 1993 & 1994 & 1995 & 1996 & 1997 & 1998 & 1999 & 2000 & 2001 & 2002 & 2003 & 2004 & 2005 & 2006 & 2007 & 2008 & 2009 & 2010 & 2011 & 2012 & 2013 & 2014 & 2015 \\
\hline \multicolumn{26}{|l|}{ Food packaging } \\
\hline $2 \mathrm{D}$ products & 412 & 420 & 412 & 444 & 440 & 457 & 492 & 516 & 544 & 581 & 606 & 751 & 804 & 831 & 842 & 861 & 875 & 812 & 795 & 610 & 617 & 627 & 625 & 643 & 600 \\
\hline Bottles & 0 & 0 & 0 & 0 & 0 & 0 & 0 & 0 & 0 & 0 & 0 & 0 & 0 & 0 & 0 & 0 & 0 & 0 & 0 & 0 & 0 & 0 & 0 & 0 & 0 \\
\hline Other rigid products & 663 & 677 & 663 & 715 & 709 & 736 & 793 & 831 & 877 & 936 & 976 & 1211 & 1295 & 1340 & 1356 & 1387 & 1409 & 1308 & 1281 & 982 & 995 & 1010 & 1006 & 1036 & 967 \\
\hline \multicolumn{26}{|l|}{ Non-food packaging } \\
\hline $2 \mathrm{D}$ products & 458 & 467 & 458 & 493 & 489 & 508 & 547 & 573 & 605 & 645 & 673 & 835 & 893 & 924 & 935 & 957 & 972 & 902 & 884 & 677 & 686 & 696 & 694 & 714 & 667 \\
\hline Bottles & 480 & 490 & 480 & 518 & 514 & 533 & 574 & 602 & 635 & 678 & 707 & 877 & 937 & 970 & 982 & 1005 & 1020 & 947 & 928 & 711 & 720 & 731 & 729 & 750 & 700 \\
\hline Other rigid products & 252 & 257 & 252 & 271 & 269 & 279 & 301 & 315 & 332 & 355 & 370 & 459 & 491 & 508 & 514 & 526 & 535 & 496 & 486 & 373 & 377 & 383 & 382 & 393 & 367 \\
\hline Electrical\&electronics & 166 & 169 & 166 & 178 & 177 & 184 & 198 & 207 & 219 & 234 & 244 & 302 & 323 & 334 & 339 & 346 & 352 & 327 & 320 & 712 & 568 & 446 & 472 & 486 & 601 \\
\hline \multicolumn{26}{|l|}{ Building\&construction } \\
\hline $2 D$ products & 0 & 0 & 0 & 0 & 0 & 0 & 0 & 0 & 0 & 0 & 0 & 0 & 0 & 0 & 0 & 0 & 0 & 0 & 0 & 0 & 0 & 0 & 0 & 0 & 0 \\
\hline Pipes & 267 & 272 & 267 & 287 & 285 & 296 & 319 & 334 & 352 & 376 & 392 & 486 & 520 & 538 & 545 & 558 & 566 & 526 & 515 & 700 & 760 & 619 & 655 & 674 & 776 \\
\hline Other rigid $p$ & 0 & 0 & 0 & 0 & 0 & 0 & 0 & 0 & 0 & 0 & 0 & 0 & 0 & 0 & 0 & 0 & 0 & 0 & 0 & 0 & 0 & 0 & 0 & 0 & 0 \\
\hline \multicolumn{26}{|l|}{ Agriculture } \\
\hline 2D products & 0 & 0 & 0 & 0 & 0 & 0 & 0 & 0 & 0 & 0 & 0 & 0 & 0 & 0 & 0 & 0 & 0 & 0 & 0 & 0 & 0 & 0 & 0 & 0 & 0 \\
\hline Pipes & 0 & 0 & 0 & 0 & 0 & 0 & 0 & 0 & 0 & 0 & 0 & 0 & 0 & 0 & 0 & 0 & 0 & 0 & 0 & 0 & 0 & 0 & 0 & 0 & 0 \\
\hline Other rigid products & 313 & 320 & 313 & 337 & 335 & 348 & 374 & 392 & 414 & 442 & 461 & 572 & 611 & 632 & 640 & 655 & 665 & 617 & 605 & 716 & 700 & 667 & 668 & 726 & 778 \\
\hline Fibers & 897 & 940 & 985 & 1032 & 1082 & 1134 & 1188 & 1245 & 1305 & 1367 & 1433 & 1502 & 1574 & 1649 & 1729 & 1812 & 1899 & 1990 & 2085 & 2185 & 2290 & 2400 & 2515 & 2636 & 2763 \\
\hline \multicolumn{26}{|l|}{ Other } \\
\hline 2D products & 97 & 99 & 97 & 104 & 103 & 107 & 116 & 121 & 128 & 137 & 142 & 177 & 189 & 195 & 198 & 202 & 206 & 191 & 187 & 221 & 216 & 206 & 207 & 224 & 241 \\
\hline Furniture & 968 & 988 & 968 & 1043 & 1035 & 1074 & 1157 & 1212 & 1279 & 1365 & 1424 & 1766 & 1889 & 1954 & 1978 & 2024 & 2056 & 1908 & 1869 & 2214 & 2162 & 2061 & 2066 & 2245 & 2406 \\
\hline Other rigid products & 585 & 614 & 645 & 678 & 712 & 748 & 785 & 825 & 867 & 910 & 956 & 1004 & 1055 & 1108 & 1164 & 1223 & 1285 & 1349 & 1417 & 1489 & 1564 & 1643 & 1726 & 1813 & 1904 \\
\hline
\end{tabular}


Table S2.8 Release of PET waste in kt from stock in modelling year 1-25, after which nothing more is released. 2D: two-dimensional soft.

\begin{tabular}{|c|c|c|c|c|c|c|c|c|c|c|c|c|c|c|c|c|c|c|c|c|c|c|c|c|c|}
\hline modelling year & 1 & 2 & 3 & 4 & 5 & 6 & 7 & 8 & 9 & 10 & 11 & 12 & 13 & 14 & 15 & 16 & 17 & 18 & 19 & 20 & 21 & 22 & 23 & 24 & 25 \\
\hline Electrical and electronics & 2 & 2 & 2 & 2 & 2 & 1 & 1 & 1 & 1 & 0 & 0 & 0 & 0 & 0 & 0 & 0 & 0 & 0 & 0 & 0 & 0 & 0 & 0 & 0 & 0 \\
\hline \multicolumn{26}{|l|}{ Building and construction } \\
\hline $2 D$ products & 0 & 0 & 0 & 0 & 0 & 0 & 0 & 0 & 0 & 0 & 0 & 0 & 0 & 0 & 0 & 0 & 0 & 0 & 0 & 0 & 0 & 0 & 0 & 0 & 0 \\
\hline Pipes & 0 & 0 & 0 & 0 & 0 & 0 & 0 & 0 & 0 & 0 & 0 & 0 & 0 & 0 & 0 & 0 & 0 & 0 & 0 & 0 & 0 & 0 & 0 & 0 & 0 \\
\hline Other rigid products & 0 & 0 & 0 & 0 & 0 & 0 & 0 & 0 & 0 & 0 & 0 & 0 & 0 & 0 & 0 & 0 & 0 & 0 & 0 & 0 & 0 & 0 & 0 & 0 & 0 \\
\hline \multicolumn{26}{|l|}{ Agriculture } \\
\hline 2D products & 0 & 0 & 0 & 0 & 0 & 0 & 0 & 0 & 0 & 0 & 0 & 0 & 0 & 0 & 0 & 0 & 0 & 0 & 0 & 0 & 0 & 0 & 0 & 0 & 0 \\
\hline Pipes & 0 & 0 & 0 & 0 & 0 & 0 & 0 & 0 & 0 & 0 & 0 & 0 & 0 & 0 & 0 & 0 & 0 & 0 & 0 & 0 & 0 & 0 & 0 & 0 & 0 \\
\hline Other rigid products & 0 & 0 & 0 & 0 & 0 & 0 & 0 & 0 & 0 & 0 & 0 & 0 & 0 & 0 & 0 & 0 & 0 & 0 & 0 & 0 & 0 & 0 & 0 & 0 & 0 \\
\hline Fibers & 2189 & 2243 & 2165 & 1832 & 1249 & 639 & 233 & 58 & 10 & 1 & 0 & 0 & 0 & 0 & 0 & 0 & 0 & 0 & 0 & 0 & 0 & 0 & 0 & 0 & 0 \\
\hline \multicolumn{26}{|l|}{ Other } \\
\hline 2D products & 0 & 0 & 0 & 0 & 0 & 0 & 0 & 0 & 0 & 0 & 0 & 0 & 0 & 0 & 0 & 0 & 0 & 0 & 0 & 0 & 0 & 0 & 0 & 0 & 0 \\
\hline Furniture & 0 & 0 & 0 & 0 & 0 & 0 & 0 & 0 & 0 & 0 & 0 & 0 & 0 & 0 & 0 & 0 & 0 & 0 & 0 & 0 & 0 & 0 & 0 & 0 & 0 \\
\hline Other rigid products & 14 & 14 & 13 & 12 & 11 & 9 & 7 & 6 & 4 & 2 & 1 & 1 & 14 & 0 & 0 & 0 & 0 & 0 & 0 & 0 & 0 & 0 & 0 & 0 & 0 \\
\hline
\end{tabular}


Table S2.9 Release of PE waste in kt from stock in modelling year 1-50. 2D: two-dimensional soft.

\begin{tabular}{|c|c|c|c|c|c|c|c|c|c|c|c|c|c|c|c|c|c|c|c|c|c|c|c|c|c|}
\hline modelling year & 1 & 2 & 3 & 4 & 5 & 6 & 7 & 8 & 9 & 10 & 11 & 12 & 13 & 14 & 15 & 16 & 17 & 18 & 19 & 20 & 21 & 22 & 23 & 24 & 25 \\
\hline Electrical and electronics & 305 & 309 & 312 & 310 & 301 & 277 & 234 & 174 & 110 & 58 & 25 & 9 & 2 & 1 & 0 & 0 & 0 & 0 & 0 & 0 & 0 & 0 & 0 & 0 & 0 \\
\hline \multicolumn{26}{|l|}{ Building and construction } \\
\hline $2 D$ products & 20 & 26 & 33 & 41 & 50 & 61 & 72 & 85 & 98 & 113 & 128 & 143 & 159 & 175 & 191 & 206 & 222 & 236 & 250 & 263 & 275 & 285 & 295 & 302 & 307 \\
\hline Pipes & 45 & 58 & 73 & 91 & 111 & 135 & 161 & 189 & 219 & 251 & 285 & 319 & 354 & 390 & 425 & 459 & 493 & 526 & 556 & 585 & 612 & 635 & 656 & 672 & 684 \\
\hline Other rigid products & 0 & 0 & 0 & 0 & 0 & 0 & 0 & 0 & 0 & 0 & 0 & 0 & 0 & 0 & 0 & 0 & 0 & 0 & 0 & 0 & 0 & 0 & 0 & 0 & 0 \\
\hline \multicolumn{26}{|l|}{ Agriculture } \\
\hline $2 \mathrm{D}$ products & 295 & 275 & 175 & 58 & 8 & 1 & 0 & 0 & 0 & 0 & 0 & 0 & 0 & 0 & 0 & 0 & 0 & 0 & 0 & 0 & 0 & 0 & 0 & 0 & 0 \\
\hline Pipes & 64 & 59 & 38 & 13 & 2 & 0 & 0 & 0 & 0 & 0 & 0 & 0 & 0 & 0 & 0 & 0 & 0 & 0 & 0 & 0 & 0 & 0 & 0 & 0 & 0 \\
\hline Other rigid products & 48 & 45 & 28 & 9 & 1 & 0 & 0 & 0 & 0 & 0 & 0 & 0 & 0 & 0 & 0 & 0 & 0 & 0 & 0 & 0 & 0 & 0 & 0 & 0 & 0 \\
\hline Fibers & 836 & 857 & 827 & 700 & 477 & 244 & 89 & 22 & 4 & 0 & 0 & 0 & 0 & 0 & 0 & 0 & 0 & 0 & 0 & 0 & 0 & 0 & 0 & 0 & 0 \\
\hline \multicolumn{26}{|l|}{ Other } \\
\hline $2 \mathrm{D}$ products & 0 & 0 & 0 & 0 & 0 & 0 & 0 & 0 & 0 & 0 & 0 & 0 & 0 & 0 & 0 & 0 & 0 & 0 & 0 & 0 & 0 & 0 & 0 & 0 & 0 \\
\hline Furniture & 231 & 220 & 205 & 187 & 164 & 137 & 109 & 81 & 55 & 35 & 20 & 11 & 5 & 2 & 1 & 0 & 0 & 0 & 0 & 0 & 0 & 0 & 0 & 0 & 0 \\
\hline Other rigid products & 1634 & 1559 & 1455 & 1321 & 1158 & 970 & 769 & 571 & 393 & 249 & 145 & 77 & 37 & 16 & 6 & 2 & 1 & 0 & 0 & 0 & 0 & 0 & 0 & 0 & 0 \\
\hline modelling year & 26 & 27 & 28 & 29 & 30 & 31 & 32 & 33 & 34 & 35 & 36 & 37 & 38 & 39 & 40 & 41 & 42 & 43 & 44 & 45 & 46 & 47 & 48 & 49 & 50 \\
\hline Electrical and electronics & 0 & 0 & 0 & 0 & 0 & 0 & 0 & 0 & 0 & 0 & 0 & 0 & 0 & 0 & 0 & 0 & 0 & 0 & 0 & 0 & 0 & 0 & 0 & 0 & 0 \\
\hline \multicolumn{26}{|l|}{ Building and construction } \\
\hline $2 D$ products & 310 & 310 & 308 & 302 & 294 & 282 & 268 & 252 & 233 & 213 & 191 & 170 & 148 & 127 & 108 & 90 & 73 & 59 & 47 & 36 & 28 & 21 & 15 & 11 & 8 \\
\hline Pipes & 690 & 691 & 685 & 673 & 654 & 629 & 597 & 560 & 518 & 473 & 426 & 378 & 330 & 283 & 240 & 199 & 163 & 131 & 104 & 81 & 61 & 46 & 34 & 25 & 17 \\
\hline Other rigid products & 0 & 0 & 0 & 0 & 0 & 0 & 0 & 0 & 0 & 0 & 0 & 0 & 0 & 0 & 0 & 0 & 0 & 0 & 0 & 0 & 0 & 0 & 0 & 0 & 0 \\
\hline \multicolumn{26}{|l|}{ Agriculture } \\
\hline $2 \mathrm{D}$ products & 0 & 0 & 0 & 0 & 0 & 0 & 0 & 0 & 0 & 0 & 0 & 0 & 0 & 0 & 0 & 0 & 0 & 0 & 0 & 0 & 0 & 0 & 0 & 0 & 0 \\
\hline Pipes & 0 & 0 & 0 & 0 & 0 & 0 & 0 & 0 & 0 & 0 & 0 & 0 & 0 & 0 & 0 & 0 & 0 & 0 & 0 & 0 & 0 & 0 & 0 & 0 & 0 \\
\hline Other rigid products & 0 & 0 & 0 & 0 & 0 & 0 & 0 & 0 & 0 & 0 & 0 & 0 & 0 & 0 & 0 & 0 & 0 & 0 & 0 & 0 & 0 & 0 & 0 & 0 & 0 \\
\hline Fibers & 0 & 0 & 0 & 0 & 0 & 0 & 0 & 0 & 0 & 0 & 0 & 0 & 0 & 0 & 0 & 0 & 0 & 0 & 0 & 0 & 0 & 0 & 0 & 0 & 0 \\
\hline \multicolumn{26}{|l|}{ Other } \\
\hline $2 \mathrm{D}$ products & 0 & 0 & 0 & 0 & 0 & 0 & 0 & 0 & 0 & 0 & 0 & 0 & 0 & 0 & 0 & 0 & 0 & 0 & 0 & 0 & 0 & 0 & 0 & 0 & 0 \\
\hline Furniture & 0 & 0 & 0 & 0 & 0 & 0 & 0 & 0 & 0 & 0 & 0 & 0 & 0 & 0 & 0 & 0 & 0 & 0 & 0 & 0 & 0 & 0 & 0 & 0 & 0 \\
\hline Other rigid products & 0 & 0 & 0 & 0 & 0 & 0 & 0 & 0 & 0 & 0 & 0 & 0 & 0 & 0 & 0 & 0 & 0 & 0 & 0 & 0 & 0 & 0 & 0 & 0 & 0 \\
\hline
\end{tabular}


Table S2.10 Release of PP waste in kt from stock in modelling year 1-50. 2D: two-dimensional soft.

\begin{tabular}{|c|c|c|c|c|c|c|c|c|c|c|c|c|c|c|c|c|c|c|c|c|c|c|c|c|c|}
\hline modelling year & 1 & 2 & 3 & 4 & 5 & 6 & 7 & 8 & 9 & 10 & 11 & 12 & 13 & 14 & 15 & 16 & 17 & 18 & 19 & 20 & 21 & 22 & 23 & 24 & 25 \\
\hline Electrical and electronics & 305 & 309 & 312 & 310 & 301 & 277 & 234 & 174 & 110 & 58 & 25 & 9 & 2 & 1 & 0 & 0 & 0 & 0 & 0 & 0 & 0 & 0 & 0 & 0 & 0 \\
\hline \multicolumn{26}{|l|}{ Building and construction } \\
\hline $2 D$ products & 0 & 0 & 0 & 0 & 0 & 0 & 0 & 0 & 0 & 0 & 0 & 0 & 0 & 0 & 0 & 0 & 0 & 0 & 0 & 0 & 0 & 0 & 0 & 0 & 0 \\
\hline Pipes & 29 & 37 & 47 & 58 & 72 & 87 & 103 & 122 & 142 & 163 & 186 & 209 & 233 & 257 & 282 & 306 & 330 & 353 & 375 & 396 & 415 & 431 & 445 & 457 & 464 \\
\hline Other rigid products & 0 & 0 & 0 & 0 & 0 & 0 & 0 & 0 & 0 & 0 & 0 & 0 & 0 & 0 & 0 & 0 & 0 & 0 & 0 & 0 & 0 & 0 & 0 & 0 & 0 \\
\hline \multicolumn{26}{|l|}{ Agriculture } \\
\hline 2D products & 295 & 275 & 175 & 58 & 8 & 1 & 0 & 0 & 0 & 0 & 0 & 0 & 0 & 0 & 0 & 0 & 0 & 0 & 0 & 0 & 0 & 0 & 0 & 0 & 0 \\
\hline Pipes & 64 & 59 & 38 & 13 & 2 & 0 & 0 & 0 & 0 & 0 & 0 & 0 & 0 & 0 & 0 & 0 & 0 & 0 & 0 & 0 & 0 & 0 & 0 & 0 & 0 \\
\hline Other rigid products & 48 & 45 & 28 & 9 & 1 & 0 & 0 & 0 & 0 & 0 & 0 & 0 & 0 & 0 & 0 & 0 & 0 & 0 & 0 & 0 & 0 & 0 & 0 & 0 & 0 \\
\hline Fibers & 2339 & 2397 & 2314 & 1958 & 1335 & 683 & 249 & 62 & 11 & 1 & 0 & 0 & 0 & 0 & 0 & 0 & 0 & 0 & 0 & 0 & 0 & 0 & 0 & 0 & 0 \\
\hline \multicolumn{26}{|l|}{ Other } \\
\hline 2D products & 0 & 0 & 0 & 0 & 0 & 0 & 0 & 0 & 0 & 0 & 0 & 0 & 0 & 0 & 0 & 0 & 0 & 0 & 0 & 0 & 0 & 0 & 0 & 0 & 0 \\
\hline Furniture & 231 & 220 & 205 & 187 & 164 & 137 & 109 & 81 & 55 & 35 & 20 & 11 & 5 & 2 & 1 & 0 & 0 & 0 & 0 & 0 & 0 & 0 & 0 & 0 & 0 \\
\hline Other rigid products & 1634 & 1559 & 1455 & 1321 & 1158 & 970 & 769 & 571 & 393 & 249 & 145 & 77 & 37 & 16 & 6 & 2 & 1 & 0 & 0 & 0 & 0 & 0 & 0 & 0 & 0 \\
\hline modelling year & 26 & 27 & 28 & 29 & 30 & 31 & 32 & 33 & 34 & 35 & 36 & 37 & 38 & 39 & 40 & 41 & 42 & 43 & 44 & 45 & 46 & 47 & 48 & 49 & 50 \\
\hline Electrical and electronics & 0 & 0 & 0 & 0 & 0 & 0 & 0 & 0 & 0 & 0 & 0 & 0 & 0 & 0 & 0 & 0 & 0 & 0 & 0 & 0 & 0 & 0 & 0 & 0 & 0 \\
\hline \multicolumn{26}{|l|}{ Building and construction } \\
\hline $2 D$ products & 0 & 0 & 0 & 0 & 0 & 0 & 0 & 0 & 0 & 0 & 0 & 0 & 0 & 0 & 0 & 0 & 0 & 0 & 0 & 0 & 0 & 0 & 0 & 0 & 0 \\
\hline Pipes & 468 & 468 & 463 & 454 & 440 & 421 & 399 & 373 & 344 & 313 & 280 & 248 & 216 & 185 & 156 & 129 & 106 & 85 & 67 & 52 & 40 & 30 & 22 & 16 & 11 \\
\hline Other rigid products & 0 & 0 & 0 & 0 & 0 & 0 & 0 & 0 & 0 & 0 & 0 & 0 & 0 & 0 & 0 & 0 & 0 & 0 & 0 & 0 & 0 & 0 & 0 & 0 & 0 \\
\hline \multicolumn{26}{|l|}{ Agriculture } \\
\hline $2 \mathrm{D}$ products & 0 & 0 & 0 & 0 & 0 & 0 & 0 & 0 & 0 & 0 & 0 & 0 & 0 & 0 & 0 & 0 & 0 & 0 & 0 & 0 & 0 & 0 & 0 & 0 & 0 \\
\hline Pipes & 0 & 0 & 0 & 0 & 0 & 0 & 0 & 0 & 0 & 0 & 0 & 0 & 0 & 0 & 0 & 0 & 0 & 0 & 0 & 0 & 0 & 0 & 0 & 0 & 0 \\
\hline Other rigid products & 0 & 0 & 0 & 0 & 0 & 0 & 0 & 0 & 0 & 0 & 0 & 0 & 0 & 0 & 0 & 0 & 0 & 0 & 0 & 0 & 0 & 0 & 0 & 0 & 0 \\
\hline Fibers & 0 & 0 & 0 & 0 & 0 & 0 & 0 & 0 & 0 & 0 & 0 & 0 & 0 & 0 & 0 & 0 & 0 & 0 & 0 & 0 & 0 & 0 & 0 & 0 & 0 \\
\hline \multicolumn{26}{|l|}{ Other } \\
\hline 2D products & 0 & 0 & 0 & 0 & 0 & 0 & 0 & 0 & 0 & 0 & 0 & 0 & 0 & 0 & 0 & 0 & 0 & 0 & 0 & 0 & 0 & 0 & 0 & 0 & 0 \\
\hline Furniture & 0 & 0 & 0 & 0 & 0 & 0 & 0 & 0 & 0 & 0 & 0 & 0 & 0 & 0 & 0 & 0 & 0 & 0 & 0 & 0 & 0 & 0 & 0 & 0 & 0 \\
\hline Other rigid products & 0 & 0 & 0 & 0 & 0 & 0 & 0 & 0 & 0 & 0 & 0 & 0 & 0 & 0 & 0 & 0 & 0 & 0 & 0 & 0 & 0 & 0 & 0 & 0 & 0 \\
\hline
\end{tabular}




\section{S2.5 Modelling the influence of reduced quality/functionality}

As presented in section S1.1, the recycled plastic produced in one year, $n$, works as input to the plastic production in the following year, $n+1$. However, the quality and functionality of recycled plastic is often

reduced, compared to virgin plastic. To account for this, different aspects were included in the model, as described in the following sections.

\section{S2.5.1 Cascading pathways and downcycling issues}

First, as the recycled plastic might lose quality during recycling (e.g. due to contamination, degradation, etc.), the recycled plastic might not be applicable in the same product group and/or the same sector as it came from originally. Thus closed-loop recycling is often not possible and the recycled plastic is cascaded to another product group and/or sector (often termed downcycling).

Regarding estimation of cascading pathways, scant information is available in the literature, except for a few examples for packaging plastic ${ }^{25,26}$. On this basis, parts of the PET food packaging was assumed recycled into new food packaging ${ }^{4,27}$, while all PE and PP food packaging was assumed recycled into the Non-food packaging or Others sectors. Moreover, a considerable share of PET food packaging was assumed to be recycled into fibers ${ }^{26}$. Due to lack of data, all flows from non-packaging sectors were assumed to be recycled within the same sector and product group, i.e. in a closed-loop (with few exceptions). Reflecting material homogeneity, lack of contamination, and known origin ${ }^{28}$, all preconsumer plastic waste (i.e. plastic manufacturing and processing residues) was assumed also to be recycled in a closed-loop. Specific values for PET, PE and PP flows, as well as explanation of assumptions, is provided in the following sections.

\section{S.2.5.1.1 PET flows}

Table S2.11 illustrates how the cascading pathways were modelled for PET flows in the baseline scenario. The table presents transfer coefficients [\%] from one product group in one sector (left column), to one or more product groups and sectors (the remaining table). Thus, all transfer coefficients on the same row sums to $100 \%$. As an example, $25 \%$ of the Other rigid products in the Food packaging sector that is assumed recycled, was assumed recycled in a closed-loop to Other rigid products in the Food packaging sector, whereas the remaining $75 \%$ of what was recycled, was assumed recycled in an open loop to Other rigid products in the Non-food packaging sector.

In 2017 PET bottles were reported to be recycled into 40\% sheets, 29.5\% blow molded applications, $15.5 \%$ fibers and $15 \%$ others, such as strapping ${ }^{26}$, where sheets was assumed to be trays (modelled as other rigid products), blow molded applications to be bottles and others to be other rigid non-food packaging products. Where PET trays are assumed to predominately be used for food, $66 \%$ of PET bottles were assumed to be for food and $33 \%$ for non-food applications ${ }^{8}$. Thus, bottles for food were assumed to be recycled into food bottles, other rigid food packaging products, non-food bottles, other rigid non-food products and fibers, whereas non-food bottles were assumed to be recycled into non-food bottles, other rigid non-food products and fibers. Other rigid packaging products were assumed to be recycled to new other rigid packaging products. As it is possible to recycle PET food trays to new food-grade trays, Other rigid food packaging were assumed to be recycled into $90 \%$ in a closed-loop and $10 \%$ to Other rigid nonfood packaging, based on the division provided for source-separated rigid plastic waste in ${ }^{8}$. Other rigid non-food packaging were assumed recycled exclusively in a close-loop. As no information was available for two dimension PET packaging, all were assumed to be recycled exclusively into other rigid non-food packaging.

All products in the Electrical and electronics, as well as the Fibers sectors, were assumed to be recycled in a closed-loop, as no other data were available. 
Regarding agricultural film, one share is used in new agricultural film and pipes, and another in production of black garbage bags ${ }^{29}$. Thus, of the recycled agricultural soft two-dimensional products, $1 / 3$ was assumed recycled into soft, two-dimensional non-food packaging, 1/3 to agricultural pipes and 1/3 to agricultural soft, two-dimensional products. Agricultural pipes and other rigid products were assumed recycled in a closed-loop.

Only a limited share of the PET flows appear in the Others sector. As no data were available regarding the recycling pathways for these, all product groups within the Others sector were assumed to be recycled into other rigid products in the Other sector, a product group expected to work as a sink for low quality material.

\section{S.2.5.1.2 PE flows}

Only few cases exist, where postconsumer PE packaging has been recycled into food-grade $P E$. This requires separate collection of a homogeneous PE waste stream, e.g. milk bottles, which is not common practice in Europe. Thus, none of the PE packaging were assumed recycled into food-grade PE. If soft and rigid plastic is source-separated separately, the rigid part will likely contain a large share of bottles (> $80 \%)^{8}$, which makes the waste suitable for recycling into new non-food bottles ${ }^{25}$. Soft plastic, mainly containing plastic bags, can be recycled into new plastic bags ${ }^{30,31}$. However, if PE waste is collected as a mixture of soft and rigid plastic, especially if it is not effectively separated from PP, recycled PE or PO (polyolefin) is produced, which is not suitable for new packaging production ${ }^{25}$. In such cases, the recycled plastic can be used for applications such as park benches, plant trays ${ }^{32}$, outdoor fences, floor boards, etc. ${ }^{33}$, applications within the Furniture or Other rigid products in the Others sector. On this basis, the partitioning presented in Table S2.12, was assumed for recycled PE packaging.

As no other data was available, electrical and electronics were assumed recycled in a closed loop.

The partitioning of agricultural products groups were based on Briassoulis et al. ${ }^{29}$, as described for PET.

PE products with the Building and construction sector were assumed to be recycled partly to recycled PE in a closed loop and partly to recycled PO as other rigid products in the Others sector, as this sector works as a sink for low quality material.

All products in the Others sector were assumed to be recycled to PO as other rigid products in the Others sector.

\section{S.2.5.1.3 PP flows}

The partitioning of recycled PP was based on the same assumptions as for PE, with the exception of flows in the Packaging sector. As mixed PP packaging does not have the properties to be recycled into new packaging ${ }^{25}$ and since the polymers in the PP degrades significantly, each time it is recycled, thereby reducing the quality compared to virgin plastic ${ }^{28,34}$, all packaging was assumed to be recycled into the Others sector, working as sinks for low quality material.

The cascading pathways for all recycled PP flows is presented in Table S2.13. 
Table S2.11: Partitioning [\%] of recycled PET from each product group, into product groups and sectors. To obtain the final transfer coefficients for the reprocessing module, used in the model, these values needs to be multiplied with the reprocessing efficiencies given in Table S2.20. 2D: Soft, two-dimensional products, Bot.: Bottles, OR: Other rigid products, Fur.: Furniture

\begin{tabular}{|c|c|c|c|c|c|c|c|c|c|c|c|c|c|c|}
\hline \multirow{2}{*}{$\begin{array}{lr}\text { Percent [\%] } & \text { Recycled } \\
\text { of waste } 7 & \text { Into } \rightarrow \\
\end{array}$} & \multicolumn{3}{|c|}{ Food packaging } & \multicolumn{3}{|c|}{ Non-food packaging } & \multirow{2}{*}{$\begin{array}{l}\text { Electrical \& } \\
\text { electronics }\end{array}$} & \multicolumn{3}{|c|}{ Agriculture } & \multicolumn{3}{|c|}{ Other } & \multirow{2}{*}{ Fibers } \\
\hline & $2 D$ & Bot. & OR & $2 D$ & Bot. & OR & & $2 D$ & Pipes & OR & $2 D$ & Fur. & OR & \\
\hline \multicolumn{15}{|l|}{ Food packaging } \\
\hline 2D products* & - & - & - & - & - & 100 & - & - & - & - & - & - & - & - \\
\hline Bottles 26,8 & - & 19.7 & 40 & - & 9.8 & 15 & - & - & - & - & - & - & - & 15.5 \\
\hline Other rigid products ${ }^{8}$ & - & & 90 & - & - & 10 & - & - & - & - & - & - & - & - \\
\hline \multicolumn{15}{|l|}{ Non-food packaging } \\
\hline 2D products* & - & - & - & - & - & 100 & - & - & - & - & - & - & - & - \\
\hline Bottles 26 & - & - & - & - & 29.5 & 55 & - & - & - & - & - & - & - & 15.5 \\
\hline Other rigid products* & - & - & - & - & - & 100 & - & - & - & - & - & - & - & \\
\hline Electrical and electronics* & - & - & - & - & - & - & 100 & - & - & - & - & - & - & - \\
\hline \multicolumn{15}{|l|}{ Agriculture } \\
\hline 2D products 29 & - & - & - & 50 & - & - & - & 50 & - & - & - & - & - & - \\
\hline Pipes* & - & - & - & - & - & - & - & - & 100 & - & - & - & - & - \\
\hline Other rigid products* & - & - & - & - & - & - & - & - & - & 100 & - & - & - & - \\
\hline Fibers* & - & - & - & - & - & - & - & - & - & - & - & - & - & 100 \\
\hline \multicolumn{15}{|l|}{ Other } \\
\hline 2D products* & - & - & - & - & - & - & - & - & - & - & - & - & 100 & - \\
\hline Furniture* & - & - & - & - & - & - & - & - & - & - & - & - & 100 & - \\
\hline Other rigid products* & - & - & - & - & - & - & - & - & - & - & - & - & 100 & - \\
\hline
\end{tabular}


Table S2.12: Partitioning [\%] of recycled PE from each product group, into product groups and sectors. To obtain the final transfer coefficients for the reprocessing module, used in the model, these values needs to be multiplied with the reprocessing efficiencies given in Table S2.25. 2D: Soft, two-dimensional products, Bot.: Bottles, OR: Other rigid products, Fur.: Furniture. B\&C: Building and Construction

\begin{tabular}{|c|c|c|c|c|c|c|c|c|c|c|c|c|c|c|c|c|}
\hline \multirow{2}{*}{$\begin{array}{l}\text { Percent [\%] } \\
\text { of waste } 7 \\
\end{array}$} & \multicolumn{3}{|c|}{ Food packaging } & \multicolumn{3}{|c|}{ Non-food packaging } & \multirow{2}{*}{$\begin{array}{l}\text { Electrical \& } \\
\text { electronics }\end{array}$} & \multicolumn{3}{|c|}{$B \& C$} & \multicolumn{3}{|c|}{ Agriculture } & \multicolumn{3}{|c|}{ Other } \\
\hline & $2 \mathrm{D}$ & Bot. & OR & $2 \mathrm{D}$ & Bot. & OR & & $2 \mathrm{D}$ & Pipes & OR & $2 \mathrm{D}$ & Pipes & OR & $2 \mathrm{D}$ & Fur. & OR \\
\hline \multicolumn{17}{|l|}{ Food packaging } \\
\hline 2D products $32,33,31$ & - & - & - & - & - & 50 & - & - & - & - & - & - & - & - & 12.5 & 37.5 \\
\hline Bottles $^{32,33,25}$ & - & - & - & - & 50 & - & - & - & - & - & - & - & - & - & 12.5 & 37.5 \\
\hline Other rigid products ${ }^{32}, 33$ & - & - & - & - & - & - & - & - & - & - & - & - & - & - & 25 & 75 \\
\hline \multicolumn{17}{|l|}{ Non-food packaging } \\
\hline 2D products $32,33,31$ & - & - & - & - & - & 50 & - & - & - & - & - & - & - & - & 12.5 & 37.5 \\
\hline Bottles $^{32,33,25}$ & - & - & - & - & 50 & - & - & - & - & - & - & - & - & - & 12.5 & 37.5 \\
\hline Other rigid products 32,33 & - & - & - & - & - & - & - & - & - & - & - & - & - & - & 25 & 75 \\
\hline Electrical and electronics* & - & - & - & - & - & - & 100 & - & - & - & - & - & - & - & - & - \\
\hline \multicolumn{17}{|l|}{ Building and construction } \\
\hline 2D products & - & - & - & - & - & - & - & 50 & - & - & - & - & - & - & - & 50 \\
\hline Pipes & - & - & - & - & - & - & - & - & 50 & - & - & - & - & - & - & 50 \\
\hline Other rigid products & - & - & - & - & - & - & - & - & - & 50 & - & - & - & - & - & 50 \\
\hline \multicolumn{17}{|l|}{ Agriculture } \\
\hline 2D products 29 & - & - & - & 33.3 & - & - & - & - & - & - & 33.3 & 33.3 & - & - & - & - \\
\hline Pipes* & - & - & - & - & - & - & - & - & - & - & - & 100 & - & - & - & - \\
\hline Other rigid products* & - & - & - & - & - & - & - & - & - & - & - & - & 100 & - & - & - \\
\hline \multicolumn{17}{|l|}{ Other } \\
\hline 2D products* & - & - & - & - & - & - & - & - & - & - & - & - & - & - & - & 100 \\
\hline Furniture* & - & - & - & - & - & - & - & - & - & - & - & - & - & - & - & 100 \\
\hline Other rigid products* & - & - & - & - & - & - & - & - & - & - & - & - & - & - & - & 100 \\
\hline
\end{tabular}

* Expert assumption 
Table S2.13: Partitioning [\%] of recycled PP from each product group, into product groups and sectors. To obtain the final transfer coefficients for the reprocessing module, used in the model, these values needs to be multiplied with the reprocessing efficiencies given in Table S2.32. 2D: Soft, two-dimensional products, Bot.: Bottles, OR: Other rigid products, Fur.: Furniture. B\&C: Building and Construction.

\begin{tabular}{|c|c|c|c|c|c|c|c|c|c|c|c|c|c|c|c|c|c|}
\hline \multirow{2}{*}{$\begin{array}{lr}\text { Percent [\%] } & \text { Recycled } \\
\text { of waste } \downarrow & \text { Into } \rightarrow \\
\end{array}$} & \multicolumn{3}{|c|}{ Food packaging } & \multicolumn{3}{|c|}{ Non-food packaging } & \multirow{2}{*}{$\begin{array}{l}\text { Electrical \& } \\
\text { electronics }\end{array}$} & \multicolumn{3}{|c|}{$B \& C$} & \multicolumn{3}{|c|}{ Agriculture } & \multicolumn{3}{|c|}{ Other } & \multirow{2}{*}{ Fibers } \\
\hline & $2 \mathrm{D}$ & Bot. & OR & $2 \mathrm{D}$ & Bot. & OR & & $2 \mathrm{D}$ & Pipes & OR & $2 \mathrm{D}$ & Pipes & OR & $2 \mathrm{D}$ & Fur. & OR & \\
\hline \multicolumn{18}{|l|}{ Food packaging } \\
\hline 2D products $32,33,25,28$ & - & - & - & - & - & - & - & - & - & - & - & - & - & - & 25 & 75 & - \\
\hline Bottles $32,33,25,28$ & - & - & - & - & - & - & - & - & - & - & - & - & - & - & 25 & 75 & - \\
\hline Other rigid products $32,33,25,28$ & - & - & - & - & - & - & - & - & - & - & - & - & - & - & 25 & 75 & - \\
\hline \multicolumn{18}{|l|}{ Non-food packaging } \\
\hline 2D products $32,33,25,28$ & - & - & - & - & - & - & - & - & - & - & - & - & - & - & 25 & 75 & - \\
\hline Bottles $^{32}, 33,25,28$ & - & - & - & - & - & - & - & - & - & - & - & - & - & - & 25 & 75 & - \\
\hline Other rigid products $32,33,25,28$ & - & - & - & - & - & - & - & - & - & - & - & - & - & - & 25 & 75 & - \\
\hline Electrical and electronics* & - & - & - & - & - & - & 100 & - & - & - & - & - & - & - & - & - & - \\
\hline \multicolumn{18}{|l|}{ Building and construction } \\
\hline 2D products* & - & - & - & - & - & - & - & 50 & - & - & - & - & - & - & - & 50 & - \\
\hline Pipes* & - & - & - & - & - & - & - & - & 50 & - & - & - & - & - & - & 50 & - \\
\hline Other rigid products* & - & - & - & - & - & - & - & - & - & 50 & - & - & - & - & - & 50 & - \\
\hline \multicolumn{18}{|l|}{ Agriculture } \\
\hline 2D products 29 & - & - & - & 33.3 & - & - & - & - & - & - & 33.3 & 33.3 & - & - & - & - & - \\
\hline Pipes* & - & - & - & - & - & - & - & - & - & - & - & 100 & - & - & - & - & - \\
\hline Other rigid products* & - & - & - & - & - & - & - & - & - & - & - & - & 100 & - & - & - & - \\
\hline \multicolumn{18}{|l|}{ Other } \\
\hline 2D products* & - & - & - & - & - & - & - & - & - & - & - & - & - & - & - & 100 & - \\
\hline Furniture* & - & - & - & - & - & - & - & - & - & - & - & - & - & - & - & 100 & - \\
\hline Other rigid products* & - & - & - & - & - & - & - & - & - & - & - & - & - & - & - & 100 & - \\
\hline Fibers* & - & - & - & - & - & - & - & - & - & - & - & - & - & - & - & - & 100 \\
\hline
\end{tabular}

* Expert assumption 


\section{S2.5.2 Maximum recycled content, $R C^{\max }$}

Second, even though the recycled plastic is used within a specific product group and sector, the functionality might still be reduced compared to that of the virgin plastic. Consequently, the product group and sector using the recycled material, cannot use 100\% recycled plastic, i.e. some degree of virgin intake is necessary in order to meet the required functionality for that specific product group and sector.

An overview of $R C^{\max }$ values applied in this study is presented in Table S2.14. As PET polymers can be rebuild during recycling and decontamination ${ }^{35-37}$, values for $R C^{\max }$ were high, generally between $75 \%$ $100 \%$. For PE and especially PP, the functionality of the plastic is known to reduce significantly during recycling 25,28 and thus, $R C^{\max }$ were assumed lower for these, between 30\%-98.5\% for PE and 30\%-50\% for PP. The only exception was furniture and other rigid products within the Others sector, the sinks for lowquality plastic, assumed to be able to absorb 100\% recycled plastic. Specific details for each polymer type is described in the following sections.

Table S2.14 Overview of maximum recycled content, $R C^{\max }$, [\%] in each product group and sector of the model

\begin{tabular}{llccc}
\hline Sector & Product group & PET & PE & PP \\
\hline Food packaging & Bottles, other rigid products & $95 \%$ & $45 \%$ & $50 \%$ \\
& Soft, two-dimensional products & $95 \%$ & $60 \%$ & $50 \%$ \\
Non-food packaging & Bottles, other rigid products & $100 \%$ & $98.5 \%$ & $50 \%$ \\
& Soft, two-dimensional products & $100 \%$ & $60 \%$ & $50 \%$ \\
Building and construction & All product groups & - & $80 \%$ & $50 \%$ \\
Automotive & All product groups & - & $80 \%$ & $50 \%$ \\
Agriculture & Soft, two-dimensional products & $30 \%$ & $30 \%$ & $30 \%$ \\
& Pipes and other rigid products & $100 \%$ & $80 \%$ & $50 \%$ \\
Fibers & Fibers & $75 \%$ & $80 \%$ & $50 \%$ \\
Electrical and electronics & All product groups & $100 \%$ & $80 \%$ & $50 \%$ \\
Other & Soft, two-dimensional products & $100 \%$ & $80 \%$ & $50 \%$ \\
Other & Furniture and other rigid products & $100 \%$ & $100 \%$ & $100 \%$ \\
\hline
\end{tabular}

\section{S.2.5.2.1 PET}

For PET, both Welle ${ }^{38}$ and Lyngaard ${ }^{39}$ states that it is technically possible to use $100 \%$ recycled food-grade PET in bottles as well as trays. However, Welle and the British Plastic Federation ${ }^{38,40}$ states that bottles made of $100 \%$ recycled PET will often have a slight discoloration, and Lynggard ${ }^{39}$ prefers $95 \%$ recycled PET to produce food trays (to have an outer layer of $5 \%$ of virgin PET). Thus, the maximum limit of recycled PET possible to produce PET packaging without loss of functionality was assumed to be $95 \%$. However, for non-food packaging the share was assumed to by 100 , as this is technically feasible and several companies use $100 \%$ recycled PET in their production (e.g. MOSCA ${ }^{41}$ ).

According to PETcore Europe ${ }^{42}$ polyester fibers of both larger diameter (e.g. used to stuff soft toys) and softer diameter (e.g. woven into sweatshirts and fleece) can contain op to $100 \%$ recycled PET from bottles, whereas items like polar fleece jackets can take up to $25 \%$ recycled PET. Thus, assuming that polar fleece jackets accounts for only a smaller part of PET fibers, the PET fiber market were assumed to be able to absorb $75 \%$ recycled PET. 
As the quality of PET can be restored during recycling ${ }^{43}$, it was assumed that it is technically feasible to use $100 \%$ recycled PET in the remaining sectors, expect for Others, furniture and other rigid products.

\section{S.2.5.2.2 PE}

Regarding HDPE, the British Plastic Federation ${ }^{40}$ states that recycled HDPE in food packaging application can be to a maximum of $45 \%$. On the other hand, Dove claims to use $97-100 \%$ recycled material in their bottles for non-food purposes ${ }^{44,45}$, many of them of HDPE. Thus non-food PE bottles were assumed to be able to contain an average of $98.5 \%$ recycled PE. The same is assumed for bottles and other rigid products. Regarding LDPE, representing the majority of the two dimensional PE products, information in more scares. However, California requires a minimum of $40 \%$ recycled content in the reusable shopping bags $^{46}$, and one company advertises that they use up to $60 \%$ recycled plastic in their plastic bags ${ }^{47}$. Based on this, a maximum recycled content of $60 \%$ was assumed for both food and non-food packaging two dimensional PE.

Agricultural plastic film was reported to use up to $30 \%$ recycled plastic ${ }^{29}$, thus, the market for soft twodimensional PE agricultural products were assumed to be able to absorb $30 \%$ recycled PE.

No information was available for the possible amounts of recycled PE in the remaining sectors, thus an average between the $100 \%$ for packaging and the $60 \%$ for bags, i.e. $80 \%$ recycled PE, was assumed technical feasible in the remaining sectors, expect for Others, furniture and other rigid products.

\section{S.2.5.2.3 PP}

For PP the information is particularly scarce. However, LeBlanck ${ }^{48}$ reports that a UK based plastic design and recycling consultancy has developed a process for decontamination of PP for recycling into foodgrade, with a possibility to use up to $50 \%$ recycled materials. As no other information was available for PP, and since it is well known that PP degrades considerably during recycling ${ }^{25,28}$, thereby loosing functionality, 50\% was assumed for all sectors, expect Others, furniture and other rigid products.

As the product groups furniture and other rigid products in the Others sector work as a sink for low quality material, these product groups were assumed to be made of $100 \%$ recycled plastic for all polymers. 


\section{S2.6 Transfer coefficients (TCs)}

All transfer coefficients applied in each process on the model, for all PET, PE and PP flows, as well as the reference on which they are based, are given in the following sections in Table S2.15 to Table S2.32.

For all polymers, the imported quantities were assumed constant over time, independent on the applied growth rates.

\section{S2.6.1 PET}

Table S2.15 Transfer coefficients [\%] for the manufacturing process for PET

\begin{tabular}{|c|c|c|c|c|}
\hline \multirow{2}{*}{$\begin{array}{l}\text { Sector } \\
\text { Product group }\end{array}$} & \multicolumn{3}{|c|}{ Manufactured products to } & \multirow{2}{*}{ Total } \\
\hline & Use $^{a}$ & Exports $^{b}$ & Pre-consumer waste $^{c}$ & \\
\hline \multicolumn{5}{|l|}{ Food packaging } \\
\hline Soft, two-dimensional products & 0.84 & 0.08 & 0.081 & 1.00 \\
\hline Bottles & 0.84 & 0.08 & 0.081 & 1.00 \\
\hline Other rigid products & 0.84 & 0.08 & 0.081 & 1.00 \\
\hline \multicolumn{5}{|l|}{ Non-food packaging } \\
\hline Soft, two-dimensional products & 0.84 & 0.08 & 0.081 & 1.00 \\
\hline Bottles & 0.84 & 0.08 & 0.081 & 1.00 \\
\hline Other rigid products & 0.84 & 0.08 & 0.081 & 1.00 \\
\hline \multicolumn{5}{|l|}{ Electrical and electronics } \\
\hline Soft, two-dimensional products & 0.94 & & 0.059 & 1.00 \\
\hline Other rigid products & 0.94 & & 0.059 & 1.00 \\
\hline \multicolumn{5}{|l|}{ Agriculture } \\
\hline Soft, two-dimensional products & 0.93 & & 0.068 & 1.00 \\
\hline Pipes & 0.93 & & 0.068 & 1.00 \\
\hline Other rigid products & 0.93 & & 0.068 & 1.00 \\
\hline \multicolumn{5}{|l|}{ Automotive } \\
\hline Soft, two-dimensional products & 0.94 & & 0.057 & 1.00 \\
\hline Other rigid products & 0.80 & 0.15 & 0.057 & 1.00 \\
\hline \multicolumn{5}{|l|}{ Building and construction } \\
\hline Soft, two-dimensional products & 0.93 & & 0.069 & 1.00 \\
\hline Pipes & 0.93 & & 0.069 & 1.00 \\
\hline Other rigid products & 0.93 & & 0.069 & 1.00 \\
\hline Fibers & 0.93 & & 0.07 & 1.00 \\
\hline \multicolumn{5}{|l|}{ Others } \\
\hline Soft, two-dimensional products & 0.93 & & 0.07 & 1.00 \\
\hline Furniture & 0.93 & & 0.07 & 1.00 \\
\hline Other rigid products & 0.93 & & 0.07 & 1.00 \\
\hline Net import & 1.00 & & & 1.00 \\
\hline $\begin{array}{l}\text { a) Difference between plastic der } \\
\text { b) Packaging: difference between } \\
\text { products in the use stock and } \\
\text { the European market); Automo } \\
\text { plastic used in a vehicle }{ }^{50} \text { and } \\
\text { c) Data on plastic processing resi }\end{array}$ & $\begin{array}{l}\text { pre-cc } \\
\text { and wc } \\
\text { ipositi } \\
\text { the ne } \\
\text { lastic } \\
\text { rial se }\end{array}$ & $\begin{array}{l}\text { r waste an } \\
\text { heration (a } \\
\text { aded pack } \\
\text { er of vehic } \\
\text { he Europe }\end{array}$ & $\begin{array}{l}\text { ade; } \\
\text { ning negligible retention } \\
g \text { the same as the packag } \\
\text { raded } 49 \text {, an average ma } \\
\text { utomotive sector; }\end{array}$ & $\begin{array}{l}\text { tic packaging } \\
\text { isumed on } \\
0 \mathrm{~kg} \text { of }\end{array}$ \\
\hline
\end{tabular}


Table S2.16 Transfer coefficients [\%] for the use and source-separation process for PET

\begin{tabular}{|c|c|c|c|c|}
\hline & $\begin{array}{r}\text { Po } \\
\text { Residual } \\
\text { waste }\end{array}$ & $\begin{array}{l}\text {-consumer waste tc } \\
\text { To source- } \\
\text { separated waste }\end{array}$ & Total & References \\
\hline \multicolumn{5}{|l|}{ Food packaging } \\
\hline Soft, two-dimensional products & 0.31 & 0.70 & 1.00 & 4 \\
\hline Bottles & 0.42 & 0.58 & 1.00 & 26 \\
\hline Other rigid products & 0.45 & 0.55 & 1.00 & 4 \\
\hline \multicolumn{5}{|l|}{ Non-food packaging } \\
\hline Soft, two-dimensional products & 0.31 & 0.70 & 1.00 & 4 \\
\hline Bottles & 0.42 & 0.58 & 1.00 & 26 \\
\hline Other rigid products & 0.45 & 0.55 & 1.00 & 4 \\
\hline \multicolumn{5}{|l|}{ Electrical and electronics } \\
\hline Soft, two-dimensional products & 1.00 & & 1.00 & No PET from these sectors \\
\hline Other rigid products & 0.66 & 0.35 & 1.00 & 52 \\
\hline \multicolumn{5}{|l|}{ Agriculture } \\
\hline Soft, two-dimensional products & 0.40 & 0.60 & 1.00 & 53 \\
\hline Pipes & 0.40 & 0.60 & 1.00 & 53 \\
\hline Other rigid products & 0.40 & 0.60 & 1.00 & 53 \\
\hline \multicolumn{5}{|l|}{ Automotive } \\
\hline Soft, two-dimensional products & 1.00 & & 1.00 & No PET from these sectors \\
\hline Other rigid products & 1.00 & & 1.00 & No PET from these sectors \\
\hline \multicolumn{5}{|l|}{ Building and construction } \\
\hline Soft, two-dimensional products & 1.00 & & 1.00 & No PET from these sectors \\
\hline Pipes & 1.00 & & 1.00 & No PET from these sectors \\
\hline Other rigid products & 1.00 & & 1.00 & No PET from these sectors \\
\hline Fibers & 0.50 & 0.50 & 1.00 & 54 \\
\hline \multicolumn{5}{|l|}{ Others } \\
\hline Soft, two-dimensional products & 0.69 & 0.31 & 1.00 & 3 \\
\hline Furniture & 0.69 & 0.31 & 1.00 & 3 \\
\hline Other rigid products & 0.69 & 0.31 & 1.00 & 3 \\
\hline
\end{tabular}


Table S2.17 Transfer coefficients [\%] for the source-separated waste collection process for PET

\begin{tabular}{|c|c|c|c|}
\hline & \multicolumn{3}{|c|}{ Source-separated postconsumer waste to } \\
\hline & Exports $^{\mathrm{a}}$ & Sorting ${ }^{\mathbf{b}}$ & Total \\
\hline \multicolumn{4}{|l|}{ Food packaging } \\
\hline Soft, two-dimensional products & 0.29 & 0.71 & 1.00 \\
\hline Bottles & 0.29 & 0.71 & 1.00 \\
\hline Other rigid products & 0.29 & 0.71 & 1.00 \\
\hline \multicolumn{4}{|l|}{ Non-food packaging } \\
\hline Soft, two-dimensional products & 0.29 & 0.71 & 1.00 \\
\hline Bottles & 0.29 & 0.71 & 1.00 \\
\hline Other rigid products & 0.29 & 0.71 & 1.00 \\
\hline \multicolumn{4}{|l|}{ Electrical and electronics } \\
\hline Soft, two-dimensional products & 0.00 & 1.00 & 1.00 \\
\hline Other rigid products & 0.00 & 1.00 & 1.00 \\
\hline \multicolumn{4}{|l|}{ Agriculture } \\
\hline Soft, two-dimensional products & 0.00 & 1.00 & 1.00 \\
\hline Pipes & 0.01 & 0.99 & 1.00 \\
\hline Other rigid products & 0.00 & 1.00 & 1.00 \\
\hline \multicolumn{4}{|l|}{ Automotive } \\
\hline Soft, two-dimensional products & 0.00 & 1.00 & 1.00 \\
\hline Other rigid products & 0.00 & 1.00 & 1.00 \\
\hline \multicolumn{4}{|l|}{ Building and construction } \\
\hline Soft, two-dimensional products & 0.00 & 1.00 & 1.00 \\
\hline Pipes & 0.00 & 1.00 & 1.00 \\
\hline Other rigid products & 0.00 & 1.00 & 1.00 \\
\hline Fibers & 0.09 & 0.91 & 1.00 \\
\hline \multicolumn{4}{|l|}{ Others } \\
\hline Soft, two-dimensional products & 0.00 & 1.00 & 1.00 \\
\hline Furniture & 0.00 & 1.00 & 1.00 \\
\hline Other rigid products & 0.01 & 0.99 & 1.00 \\
\hline \multicolumn{4}{|c|}{$\begin{array}{l}\text { a) Based on the European net trade of plastic waste }{ }^{55} \text {. Separation into polymers for non-PE } \\
\text { plastic and separation into the different product categories is based on the composition } \\
\text { of the waste plastic collected in the EU. Data for waste plastic fiber (PET and PP) exports } \\
\text { in provided in 2; }\end{array}$} \\
\hline b) Difference between the waste & ed in the EU & waste $p$ & ted. \\
\hline
\end{tabular}


Table S2.18 Transfer coefficients [\%] for the residual waste collection process for PET

\begin{tabular}{|c|c|c|c|c|}
\hline & \multicolumn{3}{|c|}{ Residual post-consumer waste to } & \multirow[b]{2}{*}{ References } \\
\hline & Landfill & Incineration & Total & \\
\hline \multicolumn{5}{|l|}{ Food packaging } \\
\hline Soft, two-dimensional products & 0.40 & 0.60 & 1.00 & 3 \\
\hline Bottles & 0.40 & 0.60 & 1.00 & 3 \\
\hline Other rigid products & 0.40 & 0.60 & 1.00 & 3 \\
\hline \multicolumn{5}{|l|}{ Non-food packaging } \\
\hline Soft, two-dimensional products & 0.40 & 0.60 & 1.00 & 3 \\
\hline Bottles & 0.40 & 0.60 & 1.00 & 3 \\
\hline Other rigid products & 0.40 & 0.60 & 1.00 & 3 \\
\hline \multicolumn{5}{|l|}{ Electrical and electronics } \\
\hline Soft, two-dimensional products & 0.40 & 0.60 & 1.00 & 3 \\
\hline Other rigid products & 0.40 & 0.60 & 1.00 & 3 \\
\hline \multicolumn{5}{|l|}{ Agriculture } \\
\hline Soft, two-dimensional products & 0.40 & 0.60 & 1.00 & 3 \\
\hline Pipes & 0.40 & 0.60 & 1.00 & 3 \\
\hline Other rigid products & 0.40 & 0.60 & 1.00 & 3 \\
\hline \multicolumn{5}{|l|}{ Automotive } \\
\hline Soft, two-dimensional products & - & - & - & No PET from these sectors \\
\hline Other rigid products & - & - & - & No PET from these sectors \\
\hline \multicolumn{5}{|l|}{ Building and construction } \\
\hline Soft, two-dimensional products & - & - & - & No PET from these sectors \\
\hline Pipes & - & - & - & No PET from these sectors \\
\hline Other rigid products & - & - & - & No PET from these sectors \\
\hline Fibers & 0.40 & 0.60 & 1.00 & 3 \\
\hline \multicolumn{5}{|l|}{ Others } \\
\hline Soft, two-dimensional products & 0.40 & 0.60 & 1.00 & 3 \\
\hline Furniture & 0.40 & 0.60 & 1.00 & 3 \\
\hline Other rigid products & 0.40 & 0.60 & 1.00 & 3 \\
\hline
\end{tabular}


Table S2.19 Transfer coefficients [\%] for the sorting process for PE. 2D: Two-dimensional.

\begin{tabular}{|c|c|c|c|c|c|}
\hline & \multicolumn{4}{|c|}{ Residual post-consumer waste to } & \multirow[b]{2}{*}{ References } \\
\hline & Reprocessing & Landfill & Incineration & Total & \\
\hline \multicolumn{6}{|l|}{ Food packaging } \\
\hline Soft, 2D products & 0.58 & 0.17 & 0.25 & 1.00 & 3,4 \\
\hline Bottles & 0.83 & 0.07 & 0.10 & 1.00 & 3,4 \\
\hline Other rigid products & 0.24 & 0.30 & 0.46 & 1.00 & 3,4 \\
\hline \multicolumn{6}{|l|}{ Non-food packaging } \\
\hline Soft, 2D products & 0.58 & 0.17 & 0.25 & 1.00 & 3,4 \\
\hline Bottles & 0.83 & 0.07 & 0.10 & 1.00 & 3,4 \\
\hline Other rigid products & 0.24 & 0.30 & 0.46 & 1.00 & 3,4 \\
\hline \multicolumn{6}{|l|}{ Electrical and electronics } \\
\hline Soft, 2D products & 0.00 & 0.00 & 1.00 & 1.00 & 3,6 \\
\hline Other rigid products & 0.76 & 0.10 & 0.14 & 1.00 & 3,6 \\
\hline \multicolumn{6}{|l|}{ Agriculture } \\
\hline Soft, 2D products & 0.50 & 0.20 & 0.30 & 1.00 & 3,29 \\
\hline Pipes & 0.50 & 0.20 & 0.30 & 1.00 & 3,29 \\
\hline Other rigid products & 0.50 & 0.20 & 0.30 & 1.00 & 3,29 \\
\hline \multicolumn{6}{|l|}{ Automotive } \\
\hline Soft, 2D products & - & - & - & & No PET from these sectors \\
\hline Other rigid products & - & - & - & & No PET from these sectors \\
\hline \multicolumn{6}{|l|}{ Building and construction } \\
\hline Soft, 2D products & - & - & - & & No PET from these sectors \\
\hline Pipes & - & - & - & & No PET from these sectors \\
\hline Other rigid products & - & - & - & & No PET from these sectors \\
\hline Fibers & 0.00 & 0.40 & 0.60 & 1.00 & Expert estimate \\
\hline \multicolumn{6}{|l|}{ Others } \\
\hline Soft, 2D products & 0.53 & 0.19 & 0.28 & 1.00 & 1,3 \\
\hline Furniture & 0.55 & 0.18 & 0.27 & 1.00 & 1,3 \\
\hline Other rigid products & 0.55 & 0.18 & 0.27 & 1.00 & 1,3 \\
\hline
\end{tabular}


Table S2.20 presents the transfer coefficients applied in the model for reprocessing of PET. The reprocessing efficiencies for the product groups within the Packaging sectors, were assumed based on ${ }^{4}$. The reprocessing efficiencies for electrical and electronics were based on ${ }^{56}$, for products in the Agriculture sector on ${ }^{29}$ and for products in the Others sector on ${ }^{6}$. The division of the loss going to incineration and landfill was based on ${ }^{5}$ in all sectors.

Table S2.20 Transfer coefficients [\%] for the reprocessing of PET waste. The partitioning of finished products into sectors and product groups (cascading pathways) is provided in Table S2.11.

\begin{tabular}{|c|c|c|c|c|c|}
\hline \multirow{2}{*}{$\begin{array}{l}\text { Sector } \\
\text { Waste product group }\end{array}$} & \multicolumn{3}{|c|}{ Sorted plastic to [\%] } & \multirow{2}{*}{$\begin{array}{c}\text { Total } \\
{[\%]}\end{array}$} & \multirow{2}{*}{ References } \\
\hline & Finished products & Incineration & Landfill & & \\
\hline \multicolumn{6}{|l|}{ Food packaging } \\
\hline Soft, two-dimensional products & 77.7 & 13.5 & 8.8 & 100 & 4,5 \\
\hline Bottles & 83.3 & 10.1 & 6.6 & 100 & 4,5 \\
\hline Other rigid products & 77.7 & 13.5 & 8.8 & 100 & 4,5 \\
\hline \multicolumn{6}{|l|}{ Non-food packaging } \\
\hline Soft, two-dimensional products & 77.7 & 13.5 & 8.8 & 100 & 4,5 \\
\hline Bottles & 83.3 & 10.1 & 6.6 & 100 & 4,5 \\
\hline Other rigid products & 77.7 & 13.5 & 8.8 & 100 & 4,5 \\
\hline \multicolumn{6}{|l|}{ Electrical and electronics } \\
\hline Soft, two-dimensional products & \multicolumn{3}{|c|}{ No PET flows } & - & \\
\hline Other rigid products & 74 & 15.7 & 10.1 & 100 & 56,5 \\
\hline \multicolumn{6}{|l|}{ Agriculture } \\
\hline Soft, two-dimensional products & 23 & 46.5 & 30.5 & 100 & 29,5 \\
\hline Pipes & 23 & 46.5 & 30.5 & 100 & 29,5 \\
\hline Other rigid products & 23 & 46.5 & 30.5 & 100 & 29,5 \\
\hline \multicolumn{6}{|l|}{ Automotive } \\
\hline $\begin{array}{l}\text { Soft, two-dimensional products } \\
\text { Other rigid products }\end{array}$ & \multicolumn{3}{|c|}{ No PET flows } & $\begin{array}{l}- \\
-\end{array}$ & \\
\hline \multicolumn{6}{|l|}{ Building and construction } \\
\hline Soft, two-dimensional products & \multirow{3}{*}{\multicolumn{3}{|c|}{ No PET flows }} & - & \\
\hline Pipes & & & & - & \\
\hline Other rigid products & & & & - & \\
\hline Fibers & No PET fibers ar & orted out for $r$ & cling & - & \\
\hline \multicolumn{6}{|l|}{ Others } \\
\hline Soft, two-dimensional products & 0 & 60 & 40 & 100 & 6,5 \\
\hline Furniture & 0 & 60 & 40 & 100 & 6,5 \\
\hline Other rigid products & 0 & 60 & 40 & 100 & 6,5 \\
\hline
\end{tabular}




\section{S2.6.2 PE}

Table S2.21 Transfer coefficients [\%] for the manufacturing process for PE

\begin{tabular}{|c|c|c|c|c|}
\hline \multirow{2}{*}{$\begin{array}{l}\text { Sector } \\
\text { Product group }\end{array}$} & \multicolumn{3}{|c|}{ Manufactured products to } & \multirow{2}{*}{ Tota } \\
\hline & Use $^{a}$ & Exports $^{b}$ & Pre-consumer waste $^{c}$ & \\
\hline \multicolumn{5}{|l|}{ Food packaging } \\
\hline Soft, two-dimensional products & 0.84 & 0.07 & 0.081 & 1.00 \\
\hline Bottles & 0.84 & 0.07 & 0.081 & 1.00 \\
\hline Other rigid products & 0.84 & 0.07 & 0.081 & 1.00 \\
\hline \multicolumn{5}{|l|}{ Non-food packaging } \\
\hline Soft, two-dimensional products & 0.84 & 0.07 & 0.081 & 1.00 \\
\hline Bottles & 0.84 & 0.07 & 0.081 & 1.00 \\
\hline Other rigid products & 0.84 & 0.07 & 0.081 & 1.00 \\
\hline \multicolumn{5}{|l|}{ Electrical and electronics } \\
\hline Soft, two-dimensional products & 0.94 & & 0.059 & 1.00 \\
\hline Other rigid products & 0.94 & & 0.059 & 1.00 \\
\hline \multicolumn{5}{|l|}{ Agriculture } \\
\hline Soft, two-dimensional products & 0.93 & & 0.068 & 1.00 \\
\hline Pipes & 0.93 & & 0.068 & 1.00 \\
\hline Other rigid products & 0.93 & & 0.068 & 1.00 \\
\hline \multicolumn{5}{|l|}{ Automotive } \\
\hline Soft, two-dimensional products & 0.94 & & 0.057 & 1.00 \\
\hline Other rigid products & 0.80 & 0.15 & 0.057 & 1.00 \\
\hline \multicolumn{5}{|l|}{ Building and construction } \\
\hline Soft, two-dimensional products & 0.93 & & 0.069 & 1.00 \\
\hline Pipes & 0.93 & & 0.069 & 1.00 \\
\hline Other rigid products & 0.93 & & 0.069 & 1.00 \\
\hline Fibers & 0.93 & & 0.07 & 1.00 \\
\hline \multicolumn{5}{|l|}{ Others } \\
\hline Soft, two-dimensional products & 0.93 & & 0.07 & 1.00 \\
\hline Furniture & 0.93 & & 0.07 & 1.00 \\
\hline Other rigid products & 0.93 & & 0.07 & 1.00 \\
\hline Net import & 1.00 & & & 1.00 \\
\hline
\end{tabular}

a) Difference between plastic demand in a sector, pre-consumer waste and trade;

b) Packaging: difference between plastic demand and waste generation (assuming negligible retention of plastic packaging products in the use stock and product type composition of traded packaging the same as the packaging consumed on the European market); Automotive: product of the net number of vehicles traded ${ }^{49}$, an average mass of $250 \mathrm{~kg}$ of plastic used in a vehicle ${ }^{50}$ and composition of plastic use in the European automotive sector;

c) Data on plastic processing residues from industrial sectors 51 . 
Table S2.22 Transfer coefficients [\%] for the use and source-separation process for PE

\begin{tabular}{|c|c|c|c|c|}
\hline & \multicolumn{3}{|c|}{ Post-consumer waste to } & \multirow[b]{2}{*}{ References } \\
\hline & $\begin{array}{c}\text { Residual } \\
\text { waste }\end{array}$ & $\begin{array}{c}\text { To source- } \\
\text { separated waste }\end{array}$ & Total & \\
\hline \multicolumn{5}{|l|}{ Food packaging } \\
\hline Soft, two-dimensional products & 0.31 & 0.56 & 1.00 & 4,57 \\
\hline Bottles & 0.55 & 0.45 & 1.00 & 4 \\
\hline Other rigid products & 0.79 & 0.21 & 1.00 & 4 \\
\hline \multicolumn{5}{|l|}{ Non-food packaging } \\
\hline Soft, two-dimensional products & 0.31 & 0.56 & 1.00 & 4 \\
\hline Bottles & 0.55 & 0.45 & 1.00 & 4 \\
\hline Other rigid products & 0.79 & 0.21 & 1.00 & 4 \\
\hline \multicolumn{5}{|l|}{ Electrical and electronics } \\
\hline Soft, two-dimensional products & 1.00 & & 1.00 & No PET from these sectors \\
\hline Other rigid products & 0.66 & 0.35 & 1.00 & 52 \\
\hline \multicolumn{5}{|l|}{ Agriculture } \\
\hline Soft, two-dimensional products & 0.40 & 0.60 & 1.00 & 53 \\
\hline Pipes & 0.40 & 0.60 & 1.00 & 53 \\
\hline Other rigid products & 0.40 & 0.60 & 1.00 & 53 \\
\hline \multicolumn{5}{|l|}{ Automotive } \\
\hline Soft, two-dimensional products & 1.00 & & 1.00 & 58,59 \\
\hline Other rigid products & 1.00 & & 1.00 & 58,59 \\
\hline \multicolumn{5}{|l|}{ Building and construction } \\
\hline Soft, two-dimensional products & 0.73 & 0.28 & 1.00 & 60 \\
\hline Pipes & 0.78 & 0.23 & 1.00 & 60 \\
\hline Other rigid products & 0.78 & 0.23 & 1.00 & 60 \\
\hline Fibers & 1.00 & 0.00 & 1.00 & 54 \\
\hline \multicolumn{5}{|l|}{ Others } \\
\hline Soft, two-dimensional products & 0.69 & 0.31 & 1.00 & 3 \\
\hline Furniture & 0.69 & 0.31 & 1.00 & 3 \\
\hline Other rigid products & 0.69 & 0.31 & 1.00 & 3 \\
\hline
\end{tabular}


Table S2.23 Transfer coefficients [\%] for the source-separated waste collection process for PE

\begin{tabular}{|c|c|c|c|}
\hline & \multicolumn{3}{|c|}{ Source-separated postconsumer waste to } \\
\hline & Exports ${ }^{a}$ & Sorting ${ }^{\mathbf{b}}$ & Total \\
\hline \multicolumn{4}{|l|}{ Food packaging } \\
\hline Soft, two-dimensional products & 0.38 & 0.62 & 1.00 \\
\hline Bottles & 0.38 & 0.62 & 1.00 \\
\hline Other rigid products & 0.38 & 0.62 & 1.00 \\
\hline \multicolumn{4}{|l|}{ Non-food packaging } \\
\hline Soft, two-dimensional products & 0.38 & 0.62 & 1.00 \\
\hline Bottles & 0.38 & 0.62 & 1.00 \\
\hline Other rigid products & 0.38 & 0.62 & 1.00 \\
\hline \multicolumn{4}{|l|}{ Electrical and electronics } \\
\hline Soft, two-dimensional products & & 1.00 & 1.00 \\
\hline Other rigid products & 0.00 & 1.00 & 1.00 \\
\hline \multicolumn{4}{|l|}{ Agriculture } \\
\hline Soft, two-dimensional products & 0.01 & 0.99 & 1.00 \\
\hline Pipes & 0.01 & 0.99 & 1.00 \\
\hline Other rigid products & 0.01 & 0.99 & 1.00 \\
\hline \multicolumn{4}{|l|}{ Automotive } \\
\hline Soft, two-dimensional products & & 1.00 & 1.00 \\
\hline Other rigid products & & 1.00 & 1.00 \\
\hline \multicolumn{4}{|l|}{ Building and construction } \\
\hline Soft, two-dimensional products & 0.00 & 1.00 & 1.00 \\
\hline Pipes & 0.00 & 1.00 & 1.00 \\
\hline Other rigid products & 0.00 & 1.00 & 1.00 \\
\hline Fibers & 0.00 & 1.00 & 1.00 \\
\hline \multicolumn{4}{|l|}{ Others } \\
\hline Soft, two-dimensional products & 0.00 & 1.00 & 1.00 \\
\hline Furniture & 0.01 & 0.99 & 1.00 \\
\hline Other rigid products & 0.01 & 0.99 & 1.00 \\
\hline \multicolumn{4}{|c|}{$\begin{array}{l}\text { a) Based on the European net trade of plastic waste }{ }^{55} \text {. Separation into polymers for non-PE } \\
\text { plastic and separation into the different product categories is based on the composition of } \\
\text { the waste plastic collected in the EU. Data for waste plastic fiber (PET and PP) exports in } \\
\text { provided in }{ }^{2} \text {; }\end{array}$} \\
\hline \multicolumn{4}{|l|}{ b) $\mathrm{c}$} \\
\hline
\end{tabular}


Table S2.24 Transfer coefficients [\%] for the residual waste collection process for PE

\begin{tabular}{|c|c|c|c|c|}
\hline & \multicolumn{3}{|c|}{ Residual post-consumer waste to } & \multirow[b]{2}{*}{ References } \\
\hline & Landfill & Incineration & Total & \\
\hline \multicolumn{5}{|l|}{ Food packaging } \\
\hline Soft, two-dimensional products & 0.40 & 0.60 & 1.00 & 3 \\
\hline Bottles & 0.40 & 0.60 & 1.00 & 3 \\
\hline Other rigid products & 0.40 & 0.60 & 1.00 & 3 \\
\hline \multicolumn{5}{|l|}{ Non-food packaging } \\
\hline Soft, two-dimensional products & 0.40 & 0.60 & 1.00 & 3 \\
\hline Bottles & 0.40 & 0.60 & 1.00 & 3 \\
\hline Other rigid products & 0.40 & 0.60 & 1.00 & 3 \\
\hline \multicolumn{5}{|l|}{ Electrical and electronics } \\
\hline Soft, two-dimensional products & 0.40 & 0.60 & 1.00 & 3 \\
\hline Other rigid products & 0.40 & 0.60 & 1.00 & 3 \\
\hline \multicolumn{5}{|l|}{ Agriculture } \\
\hline Soft, two-dimensional products & 0.40 & 0.60 & 1.00 & 3 \\
\hline Pipes & 0.40 & 0.60 & 1.00 & 3 \\
\hline Other rigid products & 0.40 & 0.60 & 1.00 & 3 \\
\hline \multicolumn{5}{|l|}{ Automotive } \\
\hline Soft, two-dimensional products & & 1.00 & 1.00 & 61 \\
\hline Other rigid products & 0.10 & 0.90 & 1.00 & 61 \\
\hline \multicolumn{5}{|l|}{ Building and construction } \\
\hline Soft, two-dimensional products & 0.28 & 0.72 & 1.00 & 60 \\
\hline Pipes & 0.35 & 0.65 & 1.00 & 60 \\
\hline Other rigid products & 0.35 & 0.65 & 1.00 & 60 \\
\hline Fibers & 0.40 & 0.60 & 1.00 & 3 \\
\hline \multicolumn{5}{|l|}{ Others } \\
\hline Soft, two-dimensional products & 0.40 & 0.60 & 1.00 & 3 \\
\hline Furniture & 0.40 & 0.60 & 1.00 & 3 \\
\hline Other rigid products & 0.40 & 0.60 & 1.00 & 3 \\
\hline
\end{tabular}


Table S2.25 Transfer coefficients [\%] for the sorting process for PE

\begin{tabular}{|c|c|c|c|c|c|}
\hline & \multicolumn{4}{|c|}{ Residual post-consumer waste to } & \multirow[b]{2}{*}{ References } \\
\hline & Reprocessing & Landfill & Incineration & Total & \\
\hline \multicolumn{6}{|l|}{ Food packaging } \\
\hline Soft, 2D products & 0.58 & 0.17 & 0.25 & 1.00 & 3,4 \\
\hline Bottles & 0.76 & 0.09 & 0.14 & 1.00 & 3,4 \\
\hline Other rigid products & 0.01 & 0.39 & 0.60 & 1.00 & 3,4 \\
\hline \multicolumn{6}{|l|}{ Non-food packaging } \\
\hline Soft, 2D products & 0.58 & 0.17 & 0.25 & 1.00 & 3,4 \\
\hline Bottles & 0.76 & 0.09 & 0.14 & 1.00 & 3,4 \\
\hline Other rigid products & 0.01 & 0.39 & 0.60 & 1.00 & 3,4 \\
\hline \multicolumn{6}{|c|}{ Electrical and electronics } \\
\hline Soft, 2D products & & & 1.00 & 1.00 & 6,62 \\
\hline Other rigid products & 0.26 & 0.29 & 0.44 & 1.00 & 6,62 \\
\hline \multicolumn{6}{|l|}{ Agriculture } \\
\hline Soft, 2D products & 0.45 & 0.22 & 0.34 & 1.00 & $3,7,29$ \\
\hline Pipes & 0.38 & 0.24 & 0.37 & 1.00 & $3,7,29$ \\
\hline Other rigid products & 0.26 & 0.29 & 0.45 & 1.00 & $3,7,29$ \\
\hline \multicolumn{6}{|l|}{ Automotive } \\
\hline Soft, 2D products & - & - & - & & No PE flows \\
\hline Other rigid products & - & - & - & & No PE flows \\
\hline \multicolumn{6}{|c|}{ Building and construction } \\
\hline Soft, 2D products & 0.80 & 0.06 & 0.14 & 1.00 & 63 \\
\hline Pipes & 0.80 & 0.07 & 0.13 & 1.00 & 63 \\
\hline Other rigid products & 0.80 & 0.07 & 0.13 & 1.00 & 63 \\
\hline Fibers & 0.00 & 0.40 & 0.60 & 1.00 & Expert estimate, ${ }^{3}$ \\
\hline \multicolumn{6}{|l|}{ Others } \\
\hline Soft, 2D products & 0.53 & 0.19 & 0.28 & 1.00 & 1,3 \\
\hline Furniture & 0.55 & 0.18 & 0.27 & 1.00 & 1,3 \\
\hline Other rigid products & 0.55 & 0.18 & 0.27 & 1.00 & 1,3 \\
\hline
\end{tabular}


Table S2.26 Transfer coefficients [\%] for the reprocessing of PE waste. The partitioning of finished products into sectors and product groups (cascading pathways) is provided in Table S2.12.

\begin{tabular}{|c|c|c|c|c|c|}
\hline \multirow{2}{*}{$\begin{array}{l}\text { Sector } \\
\quad \text { Waste product group }\end{array}$} & \multicolumn{3}{|c|}{ Sorted plastic to [\%] } & \multirow{2}{*}{$\begin{array}{c}\text { Total } \\
{[\%]}\end{array}$} & \multirow{2}{*}{ References } \\
\hline & Finished products & Incineration & Landfill & & \\
\hline $\begin{array}{l}\text { Food packaging } \\
\text { Soft, two-dimensional products } \\
\text { Bottles } \\
\text { Other rigid products } \\
\end{array}$ & $\begin{array}{c}71.5 \\
92.6 \\
80 \\
\end{array}$ & $\begin{array}{c}17.2 \\
4.5 \\
12.1 \\
\end{array}$ & $\begin{array}{c}11.3 \\
2.9 \\
7.9 \\
\end{array}$ & $\begin{array}{l}100 \\
100 \\
100 \\
\end{array}$ & $\begin{array}{l}4,5 \\
4,5 \\
4,5 \\
4\end{array}$ \\
\hline $\begin{array}{l}\text { Non-food packaging } \\
\text { Soft, two-dimensional products } \\
\text { Bottles } \\
\text { Other rigid products } \\
\end{array}$ & $\begin{array}{c}71.5 \\
92.6 \\
80 \\
\end{array}$ & $\begin{array}{c}17.2 \\
4.5 \\
12.1 \\
\end{array}$ & $\begin{array}{c}11.3 \\
2.9 \\
7.9 \\
\end{array}$ & $\begin{array}{l}100 \\
100 \\
100 \\
\end{array}$ & $\begin{array}{l}4,5 \\
4,5 \\
4,5 \\
\end{array}$ \\
\hline $\begin{array}{l}\text { Electrical and electronics } \\
\text { Soft, two-dimensional products } \\
\text { Other rigid products }\end{array}$ & 88 & $\begin{array}{r}\text { ET flows } \\
7.2 \\
\end{array}$ & 4.8 & $\begin{array}{c}- \\
100\end{array}$ & 56,5 \\
\hline $\begin{array}{l}\text { Agriculture } \\
\text { Soft, two-dimensional products } \\
\text { Pipes } \\
\text { Other rigid products } \\
\end{array}$ & $\begin{array}{l}23 \\
23 \\
23\end{array}$ & $\begin{array}{l}46.5 \\
46.5 \\
46.5 \\
\end{array}$ & $\begin{array}{l}30.5 \\
30.5 \\
30.5 \\
\end{array}$ & $\begin{array}{l}100 \\
100 \\
100 \\
\end{array}$ & $\begin{array}{l}29,5 \\
29,5 \\
29,5\end{array}$ \\
\hline $\begin{array}{l}\text { Building and Construction } \\
\text { Soft, two-dimensional products } \\
\text { Pipes } \\
\text { Other rigid products } \\
\end{array}$ & $\begin{array}{l}76 \\
76 \\
76 \\
\end{array}$ & $\begin{array}{l}17 \\
15 \\
15\end{array}$ & $\begin{array}{l}7 \\
9 \\
9\end{array}$ & $\begin{array}{l}100 \\
100 \\
100 \\
\end{array}$ & $\begin{array}{l}6,60 \\
6,60 \\
6,60 \\
\end{array}$ \\
\hline $\begin{array}{l}\text { Automotive } \\
\text { Soft, two-dimensional products } \\
\text { Other rigid products }\end{array}$ & & E flows & & - & \\
\hline Fibers & No PE fibers a & orted out for $r$ & ling & - & \\
\hline $\begin{array}{l}\text { Others } \\
\text { Soft, two-dimensional products } \\
\text { Furniture } \\
\text { Other rigid products }\end{array}$ & $\begin{array}{l}0 \\
0 \\
0\end{array}$ & $\begin{array}{l}60 \\
60 \\
60\end{array}$ & $\begin{array}{l}40 \\
40 \\
40\end{array}$ & $\begin{array}{l}100 \\
100 \\
100\end{array}$ & $\begin{array}{l}6,5 \\
6,5 \\
6,5\end{array}$ \\
\hline
\end{tabular}


S2.6.3 PP

Table S2.27 Transfer coefficients [\%] for the manufacturing process for PP

\begin{tabular}{|c|c|c|c|c|}
\hline \multirow{2}{*}{$\begin{array}{l}\text { Sector } \\
\text { Product group }\end{array}$} & \multicolumn{3}{|c|}{ Manufactured products to } & \multirow{2}{*}{ Total } \\
\hline & Use $^{a}$ & Exports $^{b}$ & Pre-consumer waste ${ }^{c}$ & \\
\hline \multicolumn{5}{|l|}{ Food packaging } \\
\hline Soft, two-dimensional products & 0.63 & 0.29 & 0.081 & 1.00 \\
\hline Bottles & 0.92 & & 0.081 & 1.00 \\
\hline Other rigid products & 0.63 & 0.29 & 0.081 & 1.00 \\
\hline \multicolumn{5}{|l|}{ Non-food packaging } \\
\hline Soft, two-dimensional products & 0.63 & 0.29 & 0.081 & 1.00 \\
\hline Bottles & 0.63 & 0.29 & 0.081 & 1.00 \\
\hline Other rigid products & 0.63 & 0.29 & 0.081 & 1.00 \\
\hline \multicolumn{5}{|l|}{ Electrical and electronics } \\
\hline Soft, two-dimensional products & 0.94 & & 0.059 & 1.00 \\
\hline Other rigid products & 0.94 & & 0.059 & 1.00 \\
\hline \multicolumn{5}{|l|}{ Agriculture } \\
\hline Soft, two-dimensional products & 0.93 & & 0.068 & 1.00 \\
\hline Pipes & 0.93 & & 0.068 & 1.00 \\
\hline Other rigid products & 0.93 & & 0.068 & 1.00 \\
\hline \multicolumn{5}{|l|}{ Automotive } \\
\hline Soft, two-dimensional products & 0.94 & & 0.057 & 1.00 \\
\hline Other rigid products & 0.80 & 0.15 & 0.057 & 1.00 \\
\hline \multicolumn{5}{|l|}{ Building and construction } \\
\hline Soft, two-dimensional products & 0.93 & & 0.069 & 1.00 \\
\hline Pipes & 0.94 & $-0.01 *$ & 0.069 & 1.00 \\
\hline Other rigid products & 0.93 & & 0.069 & 1.00 \\
\hline Fibers & 0.93 & & 0.07 & 1.00 \\
\hline \multicolumn{5}{|l|}{ Others } \\
\hline Soft, two-dimensional products & 0.93 & & 0.07 & 1.00 \\
\hline Furniture & 1.15 & $-0.22 *$ & 0.07 & 1.00 \\
\hline Other rigid products & 0.93 & & 0.07 & 1.00 \\
\hline Net import & 1.00 & & & 1.00 \\
\hline
\end{tabular}

a) Difference between plastic demand in a sector, pre-consumer waste and trade;

b) Packaging: difference between plastic demand and waste generation (assuming negligible retention of plastic packaging products in the use stock and product type composition of traded packaging the same as the packaging consumed on the European market); Automotive: product of the net number of vehicles traded ${ }^{49}$, an average mass of $250 \mathrm{~kg}$ of plastic used in a vehicle ${ }^{50}$ and composition of plastic use in the European automotive sector;

c) Data on plastic processing residues from industrial sectors 51 .

* Negative values indicate net import of plastic products. 
Table S2.28 Transfer coefficients [\%] for the use and source-separation process for PP

\begin{tabular}{|c|c|c|c|c|}
\hline & $\begin{array}{l}\text { Pc } \\
\begin{array}{c}\text { Residual } \\
\text { waste }\end{array} \\
\end{array}$ & $\begin{array}{l}\text {-consumer waste to } \\
\text { To source- } \\
\text { separated waste }\end{array}$ & Total & References \\
\hline \multicolumn{5}{|l|}{ Food packaging } \\
\hline Soft, two-dimensional products & 0.31 & 0.70 & 0.00 & 4 \\
\hline Bottles & 0.55 & 0.45 & 1.00 & 4 \\
\hline Other rigid products & 1.00 & & 1.00 & 4 \\
\hline \multicolumn{5}{|l|}{ Non-food packaging } \\
\hline Soft, two-dimensional products & 0.31 & 0.70 & 1.00 & 4 \\
\hline Bottles & 0.55 & 0.45 & 1.00 & 4 \\
\hline Other rigid products & 1.00 & & 1.00 & 4 \\
\hline \multicolumn{5}{|l|}{ Electrical and electronics } \\
\hline Soft, two-dimensional products & 1.00 & & 1.00 & No PET from these sectors \\
\hline Other rigid products & 0.66 & 0.35 & 1.00 & 52 \\
\hline \multicolumn{5}{|l|}{ Agriculture } \\
\hline Soft, two-dimensional products & 0.40 & 0.60 & 1.00 & 53 \\
\hline Pipes & 0.40 & 0.60 & 1.00 & 53 \\
\hline Other rigid products & 0.40 & 0.60 & 1.00 & 53 \\
\hline \multicolumn{5}{|l|}{ Automotive } \\
\hline Soft, two-dimensional products & 1.00 & & 1.00 & 61 \\
\hline Other rigid products & 1.00 & & 1.00 & 61 \\
\hline \multicolumn{5}{|l|}{ Building and construction } \\
\hline Soft, two-dimensional products & 0.30 & 0.70 & 1.00 & 60 \\
\hline Pipes & 0.30 & 0.70 & 1.00 & 60 \\
\hline Other rigid products & 0.30 & 0.70 & 1.00 & 60 \\
\hline Fibers & 0.57 & 0.43 & 1.00 & 54 \\
\hline \multicolumn{5}{|l|}{ Others } \\
\hline Soft, two-dimensional products & 0.69 & 0.31 & 1.00 & 3 \\
\hline Furniture & 0.69 & 0.31 & 1.00 & 3 \\
\hline Other rigid products & 0.69 & 0.31 & 1.00 & 3 \\
\hline
\end{tabular}


Table S2.29 Transfer coefficients [\%] for the source-separated waste collection process for PP

\begin{tabular}{|c|c|c|c|}
\hline & \multicolumn{3}{|c|}{ Source-separated postconsumer waste to } \\
\hline & Exports $^{a}$ & Sorting $b$ & Total \\
\hline \multicolumn{4}{|l|}{ Food packaging } \\
\hline Soft, two-dimensional products & 0.16 & 0.84 & 1.00 \\
\hline Bottles & & 1.00 & 1.00 \\
\hline Other rigid products & 0.16 & 0.84 & 1.00 \\
\hline \multicolumn{4}{|l|}{ Non-food packaging } \\
\hline Soft, two-dimensional products & 0.16 & 0.84 & 1.00 \\
\hline Bottles & 0.16 & 0.84 & 1.00 \\
\hline Other rigid products & 0.16 & 0.84 & 1.00 \\
\hline \multicolumn{4}{|l|}{ Electrical and electronics } \\
\hline Soft, two-dimensional products & & 1.00 & 1.00 \\
\hline Other rigid products & 0.00 & 1.00 & 1.00 \\
\hline \multicolumn{4}{|l|}{ Agriculture } \\
\hline Soft, two-dimensional products & & 1.00 & 1.00 \\
\hline Pipes & & 1.00 & 1.00 \\
\hline Other rigid products & 0.00 & 1.00 & 1.00 \\
\hline \multicolumn{4}{|l|}{ Automotive } \\
\hline Soft, two-dimensional products & & 1.00 & 1.00 \\
\hline Other rigid products & & 1.00 & 1.00 \\
\hline \multicolumn{4}{|l|}{ Building and construction } \\
\hline Soft, two-dimensional products & & 1.00 & 1.00 \\
\hline Pipes & 0.00 & 1.00 & 1.00 \\
\hline Other rigid products & & 1.00 & 1.00 \\
\hline Fibers & 0.02 & 0.98 & 1.00 \\
\hline \multicolumn{4}{|l|}{ Others } \\
\hline Soft, two-dimensional products & & 1.00 & 1.00 \\
\hline Furniture & 0.00 & 1.00 & 1.00 \\
\hline Other rigid products & 0.00 & 1.00 & 1.00 \\
\hline
\end{tabular}

a) Based on the European net trade of plastic waste ${ }^{55}$. Separation into polymers for non-PE plastic and separation into the different product categories is based on the composition of the waste plastic collected in the EU. Data for waste plastic fiber (PET and PP) exports in provided in 2;

b) Difference between the waste collected in the EU and the waste plastic exported. 
Table S2.30 Transfer coefficients [\%] for the residual waste collection process for PP

\begin{tabular}{|c|c|c|c|c|}
\hline & \multicolumn{3}{|c|}{ Residual post-consumer waste to } & \multirow[b]{2}{*}{ References } \\
\hline & Landfill & Incineration & Total & \\
\hline \multicolumn{5}{|l|}{ Food packaging } \\
\hline Soft, two-dimensional products & 0.40 & 0.60 & 1.00 & 3 \\
\hline Bottles & 0.40 & 0.60 & 1.00 & 3 \\
\hline Other rigid products & 0.40 & 0.60 & 1.00 & 3 \\
\hline \multicolumn{5}{|l|}{ Non-food packaging } \\
\hline Soft, two-dimensional products & 0.40 & 0.60 & 1.00 & 3 \\
\hline Bottles & 0.40 & 0.60 & 1.00 & 3 \\
\hline Other rigid products & 0.40 & 0.60 & 1.00 & 3 \\
\hline \multicolumn{5}{|l|}{ Electrical and electronics } \\
\hline Soft, two-dimensional products & 0.40 & 0.60 & 1.00 & 3 \\
\hline Other rigid products & 0.40 & 0.60 & 1.00 & 3 \\
\hline \multicolumn{5}{|l|}{ Agriculture } \\
\hline Soft, two-dimensional products & 0.40 & 0.60 & 1.00 & 3 \\
\hline Pipes & 0.40 & 0.60 & 1.00 & 3 \\
\hline Other rigid products & 0.40 & 0.60 & 1.00 & 3 \\
\hline \multicolumn{5}{|l|}{ Automotive } \\
\hline Soft, two-dimensional products & 0.10 & 0.90 & 1.00 & 61 \\
\hline Other rigid products & 0.10 & 0.90 & 1.00 & 61 \\
\hline \multicolumn{5}{|l|}{ Building and construction } \\
\hline Soft, two-dimensional products & 0.35 & 0.65 & 1.00 & 60 \\
\hline Pipes & 0.35 & 0.65 & 1.00 & 60 \\
\hline Other rigid products & 0.35 & 0.65 & 1.00 & 60 \\
\hline Fibers & 0.40 & 0.60 & 1.00 & 3 \\
\hline \multicolumn{5}{|l|}{ Others } \\
\hline Soft, two-dimensional products & 0.40 & 0.60 & 1.00 & 3 \\
\hline Furniture & 0.40 & 0.60 & 1.00 & 3 \\
\hline Other rigid products & 0.40 & 0.60 & 1.00 & 3 \\
\hline
\end{tabular}


Table S2.31 Transfer coefficients [\%] for the sorting process for PP

\begin{tabular}{|c|c|c|c|c|c|}
\hline & \multicolumn{4}{|c|}{ Residual post-consumer waste to } & \multirow[b]{2}{*}{ References } \\
\hline & Reprocessing & Landfill & Incineration & Total & \\
\hline \multicolumn{6}{|l|}{ Food packaging } \\
\hline Soft, 2D products & 0.58 & 0.17 & 0.25 & 1.00 & 3,4 \\
\hline Bottles & 0.44 & 0.22 & 0.34 & 1.00 & 3,4 \\
\hline Other rigid products & & & 1.00 & 1.00 & 3,4 \\
\hline \multicolumn{6}{|l|}{ Non-food packaging } \\
\hline Soft, 2D products & 0.58 & 0.17 & 0.25 & 1.00 & 3,4 \\
\hline Bottles & 0.44 & 0.22 & 0.34 & 1.00 & 3,4 \\
\hline Other rigid products & & & 1.00 & 1.00 & 3,4 \\
\hline \multicolumn{6}{|c|}{ Electrical and electronics } \\
\hline Soft, 2D products & & & & - & \\
\hline Other rigid products & 0.12 & 0.35 & 0.53 & 1.00 & 6,62 \\
\hline \multicolumn{6}{|l|}{ Agriculture } \\
\hline Soft, 2D products & 0.45 & 0.22 & 0.34 & 1.00 & $3,7,29$ \\
\hline Pipes & 0.38 & 0.24 & 0.37 & 1.00 & $3,7,29$ \\
\hline Other rigid products & 0.26 & 0.29 & 0.45 & 1.00 & $3,7,29$ \\
\hline \multicolumn{6}{|l|}{ Automotive } \\
\hline Soft, 2D products & - & - & - & & No PE flows \\
\hline Other rigid products & - & - & - & & No PE flows \\
\hline \multicolumn{6}{|c|}{ Building and construction } \\
\hline Soft, 2D products & 0.80 & 0.07 & 0.13 & 1.00 & 60 \\
\hline Pipes & 0.80 & 0.07 & 0.13 & 1.00 & 60 \\
\hline Other rigid products & 0.80 & 0.07 & 0.13 & 1.00 & 60 \\
\hline Fibers & 0.00 & 0.40 & 0.60 & 1.00 & Expert estimate, ${ }^{3}$ \\
\hline \multicolumn{6}{|l|}{ Others } \\
\hline Soft, 2D products & 0.53 & 0.19 & 0.28 & 1.00 & 1,3 \\
\hline Furniture & 0.55 & 0.18 & 0.27 & 1.00 & 1,3 \\
\hline Other rigid products & 0.55 & 0.18 & 0.27 & 1.00 & 1,3 \\
\hline
\end{tabular}


Table S2.32 Transfer coefficients [\%] for the reprocessing process for PP

\begin{tabular}{|c|c|c|c|c|c|}
\hline \multirow{2}{*}{$\begin{array}{l}\text { Sector } \\
\text { Waste product group }\end{array}$} & \multicolumn{3}{|c|}{ Sorted plastic to [\%] } & \multirow{2}{*}{$\begin{array}{c}\text { Total } \\
{[\%]}\end{array}$} & \multirow{2}{*}{ References } \\
\hline & Finished products & Incineration & Landfill & & \\
\hline \multicolumn{6}{|l|}{ Food packaging } \\
\hline Soft, two-dimensional products & 71.5 & 17.2 & 11.3 & 100 & 4,5 \\
\hline Bottles & 81 & 11.5 & 7.5 & 100 & 4,5 \\
\hline Other rigid products & 80 & 12.1 & 7.9 & 100 & 4,5 \\
\hline \multicolumn{6}{|l|}{ Non-food packaging } \\
\hline Soft, two-dimensional products & 71.5 & 17.2 & 11.3 & 100 & 4,5 \\
\hline Bottles & 81 & 11.5 & 7.5 & 100 & 4,5 \\
\hline Other rigid products & 80 & 12.1 & 7.9 & 100 & 4,5 \\
\hline \multicolumn{6}{|l|}{ Electrical and electronics } \\
\hline Soft, two-dimensional products & & P flows & & - & \\
\hline Other rigid products & 83 & 10.3 & 6.7 & 100 & 6,5 \\
\hline \multicolumn{6}{|l|}{ Agriculture } \\
\hline Soft, two-dimensional products & 23 & 46.5 & 30.5 & 100 & 29,5 \\
\hline Pipes & 23 & 46.5 & 30.5 & 100 & 29,5 \\
\hline Other rigid products & 23 & 46.5 & 30.5 & 100 & 29,5 \\
\hline \multicolumn{6}{|l|}{ Building and Construction } \\
\hline Soft, two-dimensional products & 69 & 20 & 11 & 100 & 6,60 \\
\hline Pipes & 69 & 20 & 11 & 100 & 6,60 \\
\hline Other rigid products & 69 & 20 & 11 & 100 & 6,60 \\
\hline \multicolumn{6}{|l|}{ Automotive } \\
\hline Soft, two-dimensional products & \multirow{2}{*}{\multicolumn{3}{|c|}{ No automotive parts sorted for recycling }} & - & \\
\hline Other rigid products & & & & - & \\
\hline Fibers & No PP fiber & sorted for rec & & - & \\
\hline \multicolumn{6}{|l|}{ Others } \\
\hline Soft, two-dimensional products & 0 & 60 & 40 & 100 & 5 \\
\hline Furniture & 0 & 60 & 40 & 100 & 5 \\
\hline Other rigid products & 0 & 60 & 40 & 100 & 5 \\
\hline
\end{tabular}




\section{S3 Data quality assessment}

Table S3.1 Quality assessment of input data for SO - business as usual, following the qualitative evaluation approach from Laner et al. (2016)

\begin{tabular}{|c|c|c|c|c|c|c|c|c|c|c|}
\hline \multirow{2}{*}{ Reference } & \multicolumn{2}{|l|}{ Reliability } & \multicolumn{2}{|l|}{ Completeness } & \multicolumn{2}{|c|}{ Temporal } & \multicolumn{2}{|c|}{ Geographical correlation } & \multicolumn{2}{|l|}{ Other correlations } \\
\hline & Argument & Score & Argument & Score & Argument & Score & Argument & Score & Argument & Score \\
\hline \multicolumn{11}{|c|}{ Quality of data used for TC estimation of packaging flows } \\
\hline $\begin{array}{l}\text { Van Eygen et al. } \\
\text { (2017) }\end{array}$ & $\begin{array}{l}\text { Peer-reviewed article where the method is } \\
\text { transperently presented }\end{array}$ & 1 & $\begin{array}{l}\text { Describes all waste flows within the } \\
\text { intended polymer and product type. }\end{array}$ & 1 & $\begin{array}{l}\text { From back } \\
\text { to } 2013\end{array}$ & 3 & Austria & 2 & $\begin{array}{l}\text { The study provides mass-related flows and } \\
\text { therefore fully represent the flows } \\
\text { modelled in this study. }\end{array}$ & 1 \\
\hline $\begin{array}{l}\text { ICIS and Petcore } \\
\text { Europe (2018) }\end{array}$ & $\begin{array}{l}\text { Annual report on PET bottles recycling in Europe. } \\
\text { The report is available for PET core members only, } \\
\text { however, the methodology is assumed consistent } \\
\text { and performed by ICIS, is the world's largest } \\
\text { petrochemical market information provider. }\end{array}$ & 2 & $\begin{array}{l}\text { Includes PET bottles managed in the } \\
\text { waste stream. It is assumes that they only } \\
\text { include beverage bottles, and not non- } \\
\text { food bottles, as is the case for this study. }\end{array}$ & 2 & 2017 & 2 & Europe & 2 & $\begin{array}{l}\text { The study provides mass-related flows and } \\
\text { therefore fully represent the flows } \\
\text { modelled in this study. }\end{array}$ & 1 \\
\hline $\begin{array}{l}\text { Plastics Europe } \\
\text { (2016) }\end{array}$ & $\begin{array}{l}\text { Data from PlasticsEurope are in general well } \\
\text { trused, and based on a consistent methodology, as } \\
\text { their statistics are given on an annual basis, even } \\
\text { though the methodology is not transperent. } \\
\text { Consequently, the data is assumed reasonable } \\
\text { reliable. }\end{array}$ & 2 & Data includes plastic flows & 1 & 2016 & 1 & Europe & 2 & $\begin{array}{l}\text { Waste management data is related to the } \\
\text { treatment of total plastic waste, rather } \\
\text { than plastic waste from specific sectors. }\end{array}$ & 2 \\
\hline $\begin{array}{l}\text { Petcore Europe } \\
\text { (2019) }\end{array}$ & $\begin{array}{l}\text { The data originates from a website with no } \\
\text { references to specific studies and thus, the data } \\
\text { collection basis is neither provided nor } \\
\text { transperent. However, PETcore Europe is a well } \\
\text { trused organisation providing much statistical } \\
\text { information and there base knowledge is therefore } \\
\text { assumed to be somewhat reliable. }\end{array}$ & 2 & Data includes all recycled PET & 1 & Unknown & 4 & Europe & 2 & $\begin{array}{l}\text { The product types mentioned to be } \\
\text { produced from a specific share of the total } \\
\text { recycled PET is not exhaustive, however, } \\
\text { based on the product mentioned, it is } \\
\text { reasonable to assume that they } \\
\text { corresponds to food-contact trays. }\end{array}$ & 2 \\
\hline \multicolumn{11}{|c|}{ Quality of data used for TC estimation of building and constriction flows } \\
\hline $\begin{array}{l}\text { Faraca et al. } \\
(2019 a)\end{array}$ & Peer-reviewed paper with transperent method & 1 & $\begin{array}{l}\text { Includes reprocessing effeciencies for the } \\
\text { polymers in question (the one used in this } \\
\text { paper is for the simple system), however, } \\
\text { not specifically for building and } \\
\text { construction plastic }\end{array}$ & 2 & 2017-2030 & 2 & Denmark & 2 & $\begin{array}{l}\text { The data provides reprocessing } \\
\text { efficiencies, as wanted. }\end{array}$ & 1 \\
\hline $\begin{array}{l}\text { Plastics Europe } \\
\text { (2017) }\end{array}$ & $\begin{array}{l}\text { Data from Plastics Europe are in general well } \\
\text { trused, and based on a consistent methodology, as } \\
\text { their statistics are given on an annual basis, even } \\
\text { though the methodology is not transperent. } \\
\text { Consequently, the data is assumed reasonable } \\
\text { reliable. }\end{array}$ & 2 & $\begin{array}{l}\text { Includes post-consumer waste from } \\
\text { bulding and construction }\end{array}$ & 1 & 2014 & 2 & Europe & 1 & $\begin{array}{l}\text { The data describes mass of waste } \\
\text { distributed in different disposal routes, } \\
\text { which is the same that we are expressing } \\
\text { in this model. }\end{array}$ & 1 \\
\hline COWI (2017) & $\begin{array}{l}\text { Report conducted by consultancy company with } \\
\text { large experience within waste management }\end{array}$ & 2 & $\begin{array}{l}\text { Includes composition of hard plastic } \\
\text { collected at the recycling centers. It is } \\
\text { unknwon how much of this is from } \\
\text { building and construction. }\end{array}$ & 4 & Unknown & 4 & Denmark & 2 & $\begin{array}{l}\text { The share of non-plastic ojects in the hard } \\
\text { plasticis assumed to represent the part } \\
\text { that will be removed during sorting. Thus, } \\
\text { these numbers might overestimate the } \\
\text { acutal sorting efficiency. }\end{array}$ & 3 \\
\hline
\end{tabular}


Table S3.1 (continued) Quality assessment of input data for SO - business as usual, following the qualitative evaluation approach from Laner et al. (2016)

\begin{tabular}{|c|c|c|c|c|c|c|c|c|c|c|}
\hline \multirow{2}{*}{ Reference } & \multicolumn{2}{|l|}{ Reliability } & \multicolumn{2}{|l|}{ Completeness } & \multicolumn{2}{|c|}{ Temporal } & \multicolumn{2}{|c|}{ Geographical correlation } & \multicolumn{2}{|l|}{ Other correlations } \\
\hline & Argument & Score & Argument & Score & Argument & Score & Argument & Score & Argument & Score \\
\hline \multicolumn{11}{|c|}{ Quality of data used for TC estimation of automotive flows } \\
\hline $\begin{array}{l}\text { Plastics Europe } \\
(2013)\end{array}$ & $\begin{array}{l}\text { Data from PlasticsEurope are in general well } \\
\text { trused, and based on a consistent methodology, as } \\
\text { their statistics are given on an annual basis, even } \\
\text { though the methodology is not transperent. } \\
\text { Consequently, the data is assumed reasonable } \\
\text { reliable. }\end{array}$ & 2 & $\begin{array}{l}\text { Includes production data but is used to } \\
\text { estimate potential waste management } \\
\text { pathways }\end{array}$ & 3 & 2013 & 3 & Europe & 1 & Refer to plastic in Automotive & 1 \\
\hline $\begin{array}{l}\text { Fiore et al. } \\
\text { (2012) }\end{array}$ & Peer-reviewed paper with transperent method & 1 & $\begin{array}{l}\text { Describes waste management options of } \\
\text { shredder waste, which is the scope. }\end{array}$ & 1 & 2012 & 3 & Europe & 1 & $\begin{array}{l}\text { Only provides a qualitative description, } \\
\text { based on which a percentage is estimated. }\end{array}$ & 3 \\
\hline $\begin{array}{l}\text { Nordin et al. } \\
(2019)\end{array}$ & Public report be Svenska MiljöEmissions Data & 2 & $\begin{array}{l}\text { Includes waste management data for car } \\
\text { treatment }\end{array}$ & 1 & 2019 & 2 & Sweden & 2 & Refers to plastic in automotive waste & 1 \\
\hline \multicolumn{11}{|c|}{ Quality of data used for TC estimation of electronic flows } \\
\hline $\begin{array}{l}\text { Faraca et al. } \\
(2019 a)\end{array}$ & Peer-reviewed paper with transperent method & 1 & $\begin{array}{l}\text { Includes reprocessing effeciencies for the } \\
\text { polymers in question (the one used in this } \\
\text { paper is for the simple system), however, } \\
\text { not specifically for building and } \\
\text { construction plastic }\end{array}$ & 2 & 2017-2030 & 2 & Denmark & 2 & $\begin{array}{l}\text { The data provides reprocessing efficiencies } \\
\text { for plastic, as wanted. }\end{array}$ & 1 \\
\hline $\begin{array}{l}\text { Plastics Europe } \\
\text { (2016) }\end{array}$ & $\begin{array}{l}\text { Data from Plastics Europe are in general well } \\
\text { trused, and based on a consistent methodology, as } \\
\text { their statistics are given on an annual basis, even } \\
\text { though the methodology is not transperent. } \\
\text { Consequently, the data is assumed reasonable } \\
\text { reliable. }\end{array}$ & 2 & $\begin{array}{l}\text { All plastic flows from all sectors in Europe } \\
\text { are included }\end{array}$ & 1 & 2016 & 1 & Europe & 1 & $\begin{array}{l}\text { Waste management data is related to the } \\
\text { treatment of total plastic waste, rather } \\
\text { than plastic waste from specific sectors. }\end{array}$ & 2 \\
\hline $\begin{array}{l}\text { Buekens and } \\
\text { Yang (2014) }\end{array}$ & Data collected from offical statistics & 2 & $\begin{array}{l}\text { Provides a mounts of total WEEE, not } \\
\text { specifically plastic in WEE }\end{array}$ & 2 & 2014 & 2 & Europe & 1 & $\begin{array}{l}\text { Only provides qualitative statements, } \\
\text { based on which quantitative data is } \\
\text { assumed }\end{array}$ & 3 \\
\hline $\begin{array}{l}\text { Clarke et al. } \\
(2019)\end{array}$ & Peer-reviewed paper with transperent method & 1 & $\begin{array}{l}\text { The data expresses collection rates for } \\
\text { WEEE and not the plastic in the WEEE }\end{array}$ & 2 & 2015 & 2 & UK & 2 & Provides collection rates as wanted & 1 \\
\hline $\begin{array}{l}\text { Faraca et al. } \\
(2019 b)\end{array}$ & Peer-reviewed paper with transperent method & 1 & $\begin{array}{l}\text { Provides sorting and reprocessing } \\
\text { efficiencies for WEEE in general, not the } \\
\text { plastic in the WEEE and no distinction into } \\
\text { polymers }\end{array}$ & 2 & $2018-2050$ & 2 & Denmark & 2 & $\begin{array}{l}\text { Provides sorting and reprocessing } \\
\text { efficiencies, as wanted. }\end{array}$ & 1 \\
\hline
\end{tabular}


Table S3.1 (continued) Quality assessment of input data for SO - business as usual, following the qualitative evaluation approach from Laner et al. (2016)

\begin{tabular}{|c|c|c|c|c|c|c|c|c|c|c|}
\hline \multirow{2}{*}{ Reference } & \multirow{2}{*}{\multicolumn{2}{|c|}{ Reliability }} & \multicolumn{2}{|l|}{ Completeness } & \multicolumn{2}{|c|}{ Temporal } & \multicolumn{2}{|c|}{ Geographical correlation } & \multicolumn{2}{|l|}{ Other correlations } \\
\hline & & & Argument & Score & Argument & Score & Argument & Score & Argument & Score \\
\hline \multicolumn{11}{|c|}{ Quality of data used for TC estimation of agricultural plastic flows } \\
\hline $\begin{array}{l}\text { PlastEurope } \\
(2017)\end{array}$ & $\begin{array}{l}\text { Plasteurope.com is a business information } \\
\text { platform for the European plastics industry. It is } \\
\text { part of KI Kunststoff Information and PIE Plastics } \\
\text { Information Europe, one of the leading content } \\
\text { providers for the European plastics industry. }\end{array}$ & 2 & $\begin{array}{l}\text { Referes to agricultural plastic film waste } \\
\text { and not all agricultural plastic waste }\end{array}$ & 2 & 2017 & 2 & Europe & 1 & Provides a collection efficiency as wanted & 1 \\
\hline $\begin{array}{l}\text { Plastics Europe } \\
\text { (2016) }\end{array}$ & $\begin{array}{l}\text { Data from Plastics Europe are in general well } \\
\text { trused, and based on a consistent methodology, as } \\
\text { their statistics are given on an annual basis, even } \\
\text { though the methodology is not transperent. } \\
\text { Consequently, the data is assumed reasonable } \\
\text { reliable. }\end{array}$ & 2 & Data includes plastic flows & 1 & 2016 & 1 & Europe & 1 & $\begin{array}{l}\text { Waste management data is related to the } \\
\text { treatment of total plastic waste, rather } \\
\text { than plastic waste from specific sectors. }\end{array}$ & 2 \\
\hline $\begin{array}{l}\text { Briassoulis et } \\
\text { al. (2013a) }\end{array}$ & $\begin{array}{l}\text { Peer-reviewed paper with data from official } \\
\text { statistics, however, not always transperent } \\
\text { sources. }\end{array}$ & 2 & Includes plastic waste from agriculture & 1 & $\begin{array}{l}\text { Back to } \\
2003\end{array}$ & 3 & Europe & 1 & Data represents the intended streams & 1 \\
\hline \begin{tabular}{|l|} 
Briassoulis et \\
al. (2013b) \\
\end{tabular} & $\begin{array}{l}\text { Peer-reviewed article, collecting data from many } \\
\text { different sources. }\end{array}$ & 2 & Refers to agricultural plastic waste & 1 & $2006-2009$ & 3 & Europe & 1 & $\begin{array}{l}\text { Refers to entire plastic flows instead of } \\
\text { individual polymers }\end{array}$ & 2 \\
\hline $\begin{array}{l}\text { Faraca et al. } \\
(2019 a)\end{array}$ & Peer-reviewed paper with transperent method & 1 & $\begin{array}{l}\text { Includes reprocessing effeciencies for the } \\
\text { polymers in question (the one used in this } \\
\text { paper is for the simple system), however, } \\
\text { not specifically for building and } \\
\text { construction plastic }\end{array}$ & 2 & $2017-2030$ & 2 & Denmark & 2 & $\begin{array}{l}\text { The data provides reprocessing } \\
\text { efficiencies, as wanted. }\end{array}$ & 1 \\
\hline \multicolumn{11}{|c|}{ Quality of data used for TC estimation of plastic flows from the Others sector } \\
\hline $\begin{array}{l}\text { Plastics Europe } \\
\text { (2016) }\end{array}$ & $\begin{array}{l}\text { Data from Plastics Europe are in general well } \\
\text { trused, and based on a consistent methodology, as } \\
\text { their statistics are given on an annual basis, even } \\
\text { though the methodology is not transperent. } \\
\text { Consequently, the data is assumed reasonable } \\
\text { reliable. }\end{array}$ & 2 & Data includes plastic flows & 1 & 2016 & 1 & Europe & 1 & $\begin{array}{l}\text { Waste management data is related to the } \\
\text { treatment of total plastic waste, rather } \\
\text { than plastic waste from specific sectors. }\end{array}$ & 2 \\
\hline $\begin{array}{l}\text { Eriksen et al. } \\
\text { (2018) }\end{array}$ & Peer-reviewed paper with transperent method & 1 & $\begin{array}{l}\text { Sorting efficiencies depending on polymer } \\
\text { and product type. Average values are } \\
\text { assumed. }\end{array}$ & 1 & 2018 & 2 & Europe & 1 & $\begin{array}{l}\text { The sorting efficiencies vary depending on } \\
\text { product type, but not sector }\end{array}$ & 2 \\
\hline $\begin{array}{l}\text { Faraca et al. } \\
(2019 a)\end{array}$ & Peer-reviewed paper with transperent method & 1 & $\begin{array}{l}\text { Includes reprocessing effeciencies for the } \\
\text { polymers in question (the one used in this } \\
\text { paper is for the simple system), however, } \\
\text { not specifically for building and } \\
\text { construction plastic }\end{array}$ & 2 & $2017-2030$ & 2 & Denmark & 2 & $\begin{array}{l}\text { The data provides reprocessing } \\
\text { efficiencies, as wanted. }\end{array}$ & 1 \\
\hline \multicolumn{11}{|c|}{ Quality of data used for TC estimation of plastic flows from the fibre sector } \\
\hline $\begin{array}{l}\text { Tojo et al. } \\
\text { (2012) }\end{array}$ & $\begin{array}{l}\text { Offical report made by Norden, Nordic Council of } \\
\text { Ministers }\end{array}$ & 2 & $\begin{array}{l}\text { Describes overall textile flows, instead of } \\
\text { the flows of individual synthetic polymers }\end{array}$ & 2 & 2011 & 2 & $\begin{array}{l}\text { Denmark, } \\
\text { Finland, } \\
\text { Sweden }\end{array}$ & 2 & $\begin{array}{l}\text { Describes quantities of textiles wasted, as } \\
\text { wanted }\end{array}$ & 1 \\
\hline $\begin{array}{l}\text { Plastics Europe } \\
(2016)\end{array}$ & $\begin{array}{l}\text { Data from Plastics Europe are in general well } \\
\text { trused, and based on a consistent methodology, as } \\
\text { their statistics are given on an annual basis, even } \\
\text { though the methodology is not transperent. } \\
\text { Consequently, the data is assumed reasonable } \\
\text { reliable. }\end{array}$ & 2 & Data includes plastic flows & 1 & 2016 & 1 & Europe & 1 & $\begin{array}{l}\text { Waste management data is related to the } \\
\text { treatment of total plastic waste, rather } \\
\text { than plastic waste from specific sectors. }\end{array}$ & 2 \\
\hline
\end{tabular}


Table S3.1 (continued) Quality assessment of input data for SO - business as usual, following the qualitative evaluation approach from Laner et al. (2016)

\begin{tabular}{|c|c|c|c|c|c|c|c|c|c|c|}
\hline \multicolumn{11}{|c|}{ Quality of data used for estimation of production quantities } \\
\hline \begin{tabular}{|l}
$\begin{array}{l}\text { Eriksen et al. } \\
(2018)\end{array}$ \\
\end{tabular} & $\begin{array}{l}\text { Peer-reviewed article where the method is } \\
\text { transperently presented }\end{array}$ & 1 & $\begin{array}{l}\text { The study includes all plastic flows from } \\
\text { all sectors in Europe }\end{array}$ & 1 & 2010-2016 & 3 & Europe & 2 & Data relates to packaging, as intended & 1 \\
\hline \begin{tabular}{|l} 
Ka wecki et al. \\
$(2018)$
\end{tabular} & $\begin{array}{l}\text { Peer-reviewed article where the method is } \\
\text { transperently presented }\end{array}$ & 1 & $\begin{array}{l}\text { The study includes all plastic flows from } \\
\text { all sectors in Europe }\end{array}$ & 1 & 2014 & 2 & Europe & 1 & Data relates to packaging, as intended & 1 \\
\hline $\begin{array}{l}\text { Eriksen and } \\
\text { Astrup (2019) }\end{array}$ & $\begin{array}{l}\text { Peer-reviewed article where the method is } \\
\text { transperently presented }\end{array}$ & 1 & $\begin{array}{l}\text { The study includes the composition of } \\
\text { plastic packaging waste from households } \\
\text { and does therefore not represent plastic } \\
\text { generation or all packaging plastic }\end{array}$ & 3 & 2017 & 2 & Denmark & 1 & Data relates to packaging, as intended & 1 \\
\hline \begin{tabular}{|l} 
Van Eygen et al. \\
$(2017)$
\end{tabular} & $\begin{array}{l}\text { Peer-reviewed article where the method is } \\
\text { transperently presented }\end{array}$ & 1 & $\begin{array}{l}\text { Represents waste composition, rather } \\
\text { than packaging produced }\end{array}$ & 3 & \begin{tabular}{|l} 
Back to \\
2013
\end{tabular} & 3 & Austria & 2 & Data relates to packaging, as intended & 1 \\
\hline $\begin{array}{l}\text { Plastics Europe } \\
\text { (2018) }\end{array}$ & $\begin{array}{l}\text { Data from Plastics Europe are in general well } \\
\text { trused, and based on a consistent methodology, as } \\
\text { their statistics are given on an annual basis, even } \\
\text { though the methodology is not transperent. } \\
\text { Consequently, the data is assumed reasonable } \\
\text { reliable. }\end{array}$ & 2 & $\begin{array}{l}\text { All plastic flows from all sectors in Europe } \\
\text { are included }\end{array}$ & 1 & 2017 & 2 & Europe & 2 & Data relates to packaging, as intended & 1 \\
\hline \begin{tabular}{|l} 
Briassoulis et \\
al (2013)
\end{tabular} & $\begin{array}{l}\text { Peer-reviewed article collecting data from different } \\
\text { sources }\end{array}$ & 2 & $\begin{array}{l}\text { Composition of agricultural plastic waste, } \\
\text { not consumption }\end{array}$ & 3 & 2006-2009 & 3 & Europe & 1 & Given for specific polymers & 1 \\
\hline $\begin{array}{l}\text { Faraca and } \\
\text { Astrup (2019) }\end{array}$ & Peer-reviewed article collecting primary data & 1 & $\begin{array}{l}\text { Composition of plastic waste from } \\
\text { collected from recycling centers, not } \\
\text { production volumes }\end{array}$ & 3 & 2016 & 1 & Denmark & 2 & Given for specific polymers & 1 \\
\hline
\end{tabular}




\section{S4 Data used in the remaining scenarios}

In this chapter, it will be described, how the data from the SO_baseline has been modified in each scenario, as well as what the modifications are based on.

\section{S4.1 Constant demand (S1a)}

Growth rates of all flows in all sectors were set to 1 (equal to no additional consumption).

\section{S4.2 No export of waste (S1b)}

All transfer coefficients to export during EOL were set to 0 .

\section{S4.3 Mono-polymer design (S2a)}

Based on a detailed composition of source-separated, rigid plastic waste from Danish households, distinguishing multi-polymer plastic products from mono-polymer products, Eriksen and Astrup ${ }^{8}$ estimated the quantities of PET, PE and PP potentially converted into recycled plastic, by assuming different sorting and reprocessing efficiencies, for mono-polymer and multi-polymer products.

Based on this study, it was possible to estimate sorting and reprocessing efficiencies, for the reference situation, where the plastic waste consisted of Danish source-separated rigid plastic waste, as well as for a hypothetical situation where all plastic products were designed of mono-polymers. Assuming that the Danish plastic waste composition sufficiently represents the composition of European plastic waste, data from this study was used. However, instead of using the specific sorting and reprocessing efficiencies from Eriksen and Astrup (2019), the increase in efficiencies were used instead, as different sorting and reprocessing efficiencies were applied to the different product groups and sectors in SO: Baseline.

A summary of the change in sorting and reprocessing efficiencies for packaging flows, applied in this scenario, is provided in Table S4.1.

Table S4.1 Change of sorting and reprocessing efficiencies for all packaging flows in S2a: Mono-polymer design, compared to SO: Baseline.

\begin{tabular}{lcc}
\hline Packaging flows & \multicolumn{2}{c}{ Change of transfer coefficients [\%] } \\
& Sorting & Reprocessing \\
\hline PET (food and non-food, bottle, other rigid and 2D) & $4,70 \%$ & $7,40 \%$ \\
PE (food and non-food, bottle, other rigid and 2D) & $1,20 \%$ & $7 \%$ \\
PP (food and non-food, bottle, other rigid and 2D) & $11,90 \%$ & $2,30 \%$ \\
\hline
\end{tabular}

For flows in the Agricultural, Automotive, Building \& Construction and Others sectors, available literature is scarce, most of all given the level of details at the product-group level that was required by the model. The increase in sorting and reprocessing efficiencies achievable thanks to mono-polymer design initiatives was calculated based on data from Faraca and Astrup 9 . The study sampled Danish plastic waste collected at municipal recycling centers and characterized it according to sector, product group, polymer and level of impurities. The data on the share of multi-polymer products in plastic waste from the relevant sectors was used to calculate the increase in sorting and reprocessing efficiency. It was assumed that such share of multi-polymer products would be converted in single polymer. The increase in efficiency was equally divided between sorting and reprocessing efficiency. 
A summary of the change in sorting and reprocessing efficiencies for flows in the Agricultural, Automotive, Building \& Construction and Others sectors, applied in this scenario, is provided in Table S4.2.

Table S4.2 Change of sorting and reprocessing transfer coefficients for all flows in the Agricultural, Automotive, Building \& Construction and Others sectors in S2a: Mono-polymer design, compared to SO: Baseline.

\begin{tabular}{lcc}
\hline Polymer and product type & \multicolumn{3}{c}{ Change of transfer coefficients [\%] } \\
\hline PET (bottles/pipes, other rigid and 2D) & Sorting & Reprocessing \\
PE (bottles/pipes, other rigid and 2D) & $4,75 \%$ & $4,75 \%$ \\
PP (bottles/pipes, other rigid and 2D) & $3,75 \%$ & $3,75 \%$ \\
\hline
\end{tabular}

No change in sorting and reprocessing efficiencies were assumed for products in the Electrical and Electronics or the Fiber sector.

\section{S4.4 Alignment of rigid packaging (S2b)}

All the rigid PP and PE food packaging, produced in SO: Baseline, were in this scenario assumed to be produced in PET. Similarly, the rigid non-food PET packaging, produced in SO: Baseline was assumed to be produced in PE (for 2D and bottles) and PP (for other rigid). An overview of the quantities assumed produced in S2b: Alignment of rigid packaging, is presented in Table S4.2, accounting for the difference in densities, and assuming similar volumes of the products.

Table S4.2 Overview of packaging production quantities in SO: Baseline and S2b: Alignment of rigid packaging

\begin{tabular}{|c|c|c|}
\hline Production [kt] & SO: Baseline & S2b: Alignment of rigid packaging \\
\hline \multicolumn{3}{|l|}{$\overline{P E T}$} \\
\hline 2D food packaging & 180 & 180 \\
\hline Food bottles & 623 & $623+398 \cdot(1.38 / 0.97)^{\mathrm{a}}=1189$ \\
\hline Other rigid food packaging & 1246 & $1246+162 \cdot(1.38 / 0.97)^{a}+1244 \cdot(1.38 / 0.92)^{a}=3342$ \\
\hline 2D non-food packaging & 132 & 132 \\
\hline Non-food bottles & 956 & 0 \\
\hline Other rigid non-food packaging & 478 & 0 \\
\hline \multicolumn{3}{|l|}{$P E$} \\
\hline 2D food packaging & 4497 & 4497 \\
\hline Food bottles & 398 & 0 \\
\hline Other rigid food packaging & 162 & 0 \\
\hline 2D non-food packaging & 2408 & 2408 \\
\hline Non-food bottles & 1761 & $1761+956 \cdot(0.97 / 1.38)^{\mathrm{a}}=2433$ \\
\hline Other rigid non-food packaging & 119 & 199 \\
\hline \multicolumn{3}{|l|}{$\overline{P P}$} \\
\hline 2D food packaging & 791 & 791 \\
\hline Food bottles & 0 & 0 \\
\hline Other rigid food packaging & 1244 & 0 \\
\hline 2D non-food packaging & 878 & 878 \\
\hline Non-food bottles & 922 & 922 \\
\hline Other rigid non-food packaging & 461 & $461+478 \cdot(0.92 / 1.38)^{a}=780$ \\
\hline
\end{tabular}


Moreover, all PET food bottles were recycled into food bottles (closed-loop), all food-related other rigid PET products were recycled into food-related other rigid products (closed loop) and all soft PET packaging were recycled into soft non-food PET packaging.

\section{S4.5 Increased collection (S3)}

Haupt et al. (2018) report current collection rates of up to $87 \%$ for PET bottles collected in Switzerland. This is an example of very high collection rates for post-consumer waste fractions. Thus, based on these numbers and assuming that it might be possible to increase the collection slightly more in the future, collection efficiencies of $90 \%$ were assumed for all plastic fractions in all sectors.

An increase in collection efficiencies might lead to larger amounts of impurities in the source-separated fractions ${ }^{64}$, as well as larger shares of plastic products, not suitable for recycling. However, data on the relationship between collection rates and potential extra loss of plastic or quality reductions are very scarce. To the knowledge of the authors, the only quantitative relationship was provided by Haupt et al. ${ }^{64}$, who estimated a relationship between collection rates for PET bottles and the purity of the collected fractions. Thus, this relationship was used to estimate the potential purity reduction, cause by increased collection rates (see Table S4.3 to Table S4.5 for PET, PE and PP flows, respectively). Assuming that sorting and reprocessing efficiencies are directly related to the purity of the plastic waste streams collected, the decrease in purity was assumed equal to the decrease in sorting and reprocessing efficiencies. Thus, the decrease was split equally onto the sorting and reprocessing efficiency (see Table S4.3 to Table S4.5 for specific values used).

Table S4.3 Collection rates and purities in SO: Baseline and S3: Increased collection for PET plastic flows. 2D: Two-dimensional, CR: Collection rate, SE: Sorting efficiency, RE: Reprocessing efficiencies.

\begin{tabular}{|c|c|c|c|c|c|c|c|c|c|}
\hline & \multicolumn{2}{|c|}{ SO: Baseline } & \multicolumn{2}{|c|}{ S3: Increased collection } & \multirow{2}{*}{$\begin{array}{c}\text { Decrease in } \\
\text { purity [\%] }\end{array}$} & \multicolumn{2}{|c|}{ SO: Baseline } & \multicolumn{2}{|c|}{ S3: Increased collection } \\
\hline & $\mathrm{CR}[\%]$ & Purity [\%] ${ }^{a}$ & CR [\%] & Purity [\%] ${ }^{a}$ & & SE [\%] & RE [\%] & SE [\%] & RE [\%] \\
\hline \multicolumn{10}{|l|}{ Food packaging } \\
\hline Soft, 2D products & 70 & 92 & 90 & 85 & 7.6 & 58 & 78 & 56 & 75 \\
\hline Bottles & 58 & 94 & 90 & 85 & 9.6 & 83 & 83 & 79 & 79 \\
\hline Other rigid products & 55 & 95 & 90 & 85 & 11 & 24 & 78 & 23 & 74 \\
\hline \multicolumn{10}{|l|}{ Non-food packaging } \\
\hline Soft, 2D products & 70 & 92 & 90 & 85 & 7.6 & 58 & 78 & 56 & 75 \\
\hline Bottles & 58 & 94 & 90 & 85 & 9.6 & 83 & 83 & 79 & 79 \\
\hline Other rigid products & 55 & 95 & 90 & 85 & 11 & 24 & 78 & 23 & 74 \\
\hline Electrical and electronics & 35 & 97 & 90 & 85 & 12 & 76 & 74 & 71 & 70 \\
\hline \multicolumn{10}{|l|}{ Agriculture } \\
\hline Soft, 2D products & 60 & 93 & 90 & 85 & 8.6 & 50 & 23 & 48 & 22 \\
\hline Pipes & 60 & 93 & 90 & 85 & 8.6 & 50 & 23 & 48 & 22 \\
\hline Other rigid products & 60 & 93 & 90 & 85 & 8.6 & 50 & 23 & 48 & 22 \\
\hline Fibers & 50 & 95 & 90 & 85 & 11 & 0 & - & $0^{\mathrm{b}}$ & - \\
\hline \multicolumn{10}{|l|}{ Others } \\
\hline Soft, 2D products & 31 & 98 & 90 & 85 & 13 & 53 & 0 & 50 & $0^{\mathrm{b}}$ \\
\hline Furniture & 31 & 98 & 90 & 85 & 13 & 55 & 0 & 51 & $0^{\mathrm{b}}$ \\
\hline Other rigid products & 31 & 98 & 90 & 85 & 13 & 55 & 0 & 51 & $0^{\mathrm{b}}$ \\
\hline
\end{tabular}

a) Assumed based on purity curve from Haupt et al. ${ }^{64}$

b) Values set to 0 in SO: Baseline, remains 0, as this describes recycling possibilities/routes, rather than efficiencies. 
Table S4.4 Collection rates and purities in SO: Baseline and S3: Increased collection for PE plastic flows. 2D: Two-dimensional, CR: Collection rate, SE: Sorting efficiency, RE: Reprocessing efficiencies.

\begin{tabular}{|c|c|c|c|c|c|c|c|c|c|}
\hline & \multicolumn{2}{|c|}{ SO: Baseline } & \multicolumn{2}{|c|}{ S3: Increased collection } & \multirow{2}{*}{$\begin{array}{c}\text { Decrease in } \\
\text { purity [\%] }\end{array}$} & \multicolumn{2}{|c|}{ SO: Baseline } & \multicolumn{2}{|c|}{ S3: Increased collection } \\
\hline & CR[\%] & Purity [\%] ${ }^{\mathrm{a}}$ & CR [\%] & Purity [\%] ${ }^{a}$ & & SE [\%] & RE [\%] & SE [\%] & $\mathrm{RE}[\%]$ \\
\hline \multicolumn{10}{|l|}{ Food packaging } \\
\hline Soft, 2D products & 70 & 92 & 90 & 85 & 7.6 & 58 & 72 & 56 & 69 \\
\hline Bottles & 45 & 96 & 90 & 85 & 12 & 76 & 93 & 71 & 87 \\
\hline Other rigid products & 21 & 99 & 90 & 85 & 14 & 1 & 80 & 1 & 74 \\
\hline \multicolumn{10}{|l|}{ Non-food packaging } \\
\hline Soft, 2D products & 70 & 92 & 90 & 85 & 7.6 & 58 & 72 & 56 & 69 \\
\hline Bottles & 45 & 96 & 90 & 85 & 12 & 76 & 93 & 71 & 87 \\
\hline Other rigid products & 21 & 99 & 90 & 85 & 14 & 1 & 80 & 1 & 74 \\
\hline Electrical and electronics & 35 & 97 & 90 & 85 & 12 & 26 & 88 & 24 & 83 \\
\hline \multicolumn{10}{|l|}{ Agriculture } \\
\hline Soft, 2D products & 60 & 93 & 90 & 85 & 8.6 & 45 & 23 & 43 & 22 \\
\hline Pipes & 60 & 93 & 90 & 85 & 8.6 & 38 & 23 & 36 & 22 \\
\hline Other rigid products & 60 & 93 & 90 & 85 & 8.6 & 26 & 23 & 25 & 22 \\
\hline Automotive & 0 & - & 90 & 85 & - & - & - & $75^{b}$ & $71^{b}$ \\
\hline \multicolumn{10}{|l|}{ Building and construction } \\
\hline Soft, 2D products & 28 & 97 & 90 & 85 & 12 & 80 & 76 & 75 & 71 \\
\hline Pipes & 23 & 97 & 90 & 85 & 12 & 80 & 76 & 75 & 71 \\
\hline Other rigid products & 23 & 97 & 90 & 85 & 12 & 80 & 76 & 75 & 71 \\
\hline Fibers & 50 & 95 & 90 & 85 & 11 & 0 & - & $0^{c}$ & - \\
\hline \multicolumn{10}{|l|}{ Others } \\
\hline Soft, 2D products & 31 & 98 & 90 & 85 & 13 & 53 & 0 & 50 & $0^{c}$ \\
\hline Furniture & 31 & 98 & 90 & 85 & 13 & 50 & 0 & 47 & $0^{c}$ \\
\hline Other rigid products & 31 & 98 & 90 & 85 & 13 & 50 & 0 & 47 & $0^{c}$ \\
\hline
\end{tabular}

a) Assumed based on purity curve from Haupt et al. ${ }^{64}$

b) Assumed based on SE and RE for products within the Building and construction sector

c) Values set to 0 in SO: Baseline, remains 0, as this describes recycling possibilities/routes, rather than efficiencies. 
Table S4.5 Collection rates and purities in SO: Baseline and S3: Increased collection for PP plastic flows. 2D: Two-dimensional, CR: Collection rate, SE: Sorting efficiency, RE: Reprocessing efficiencies.

\begin{tabular}{|c|c|c|c|c|c|c|c|c|c|}
\hline & \multicolumn{2}{|c|}{ SO: Baseline } & \multicolumn{2}{|c|}{ S3: Increased collection } & \multirow{2}{*}{$\begin{array}{c}\text { Decrease in } \\
\text { purity [\%] }\end{array}$} & \multicolumn{2}{|c|}{ SO: Baseline } & \multicolumn{2}{|c|}{ S3: Increased collection } \\
\hline & CR[\%] & Purity [\%] ${ }^{\mathrm{a}}$ & CR [\%] & Purity [\%] ${ }^{a}$ & & SE [\%] & $\operatorname{RE}[\%]$ & SE [\%] & RE [\%] \\
\hline \multicolumn{10}{|l|}{ Food packaging } \\
\hline Soft, 2D products & 70 & 92 & 90 & 85 & 7.6 & 58 & 72 & 56 & 69 \\
\hline Bottles & 45 & 96 & 90 & 85 & 12 & 44 & 81 & 41 & 76 \\
\hline Other rigid products & 0 & - & 90 & 85 & - & - & 80 & $41^{b}$ & $76^{b}$ \\
\hline \multicolumn{10}{|l|}{ Non-food packaging } \\
\hline Soft, 2D products & 70 & 92 & 90 & 85 & 7.6 & 58 & 72 & 56 & 69 \\
\hline Bottles & 45 & 96 & 90 & 85 & 12 & 44 & 81 & 41 & 76 \\
\hline Other rigid products & 0 & - & 90 & 85 & - & - & 80 & $41^{b}$ & $76^{b}$ \\
\hline Electrical and electronics & 35 & 97 & 90 & 85 & 12 & 12 & 83 & 11 & 78 \\
\hline \multicolumn{10}{|l|}{ Agriculture } \\
\hline Soft, 2D products & 60 & 93 & 90 & 85 & 8.6 & 45 & 23 & 43 & 22 \\
\hline Pipes & 60 & 93 & 90 & 85 & 8.6 & 38 & 23 & 36 & 22 \\
\hline Other rigid products & 60 & 93 & 90 & 85 & 8.6 & 26 & 23 & 25 & 22 \\
\hline Automotive & 0 & - & 90 & 85 & - & - & - & $77^{d}$ & $66^{d}$ \\
\hline \multicolumn{10}{|l|}{ Building and construction } \\
\hline Soft, 2D products & 70 & 92 & 90 & 85 & 7.6 & 80 & 69 & 77 & 66 \\
\hline Pipes & 70 & 92 & 90 & 85 & 7.6 & 80 & 69 & 77 & 66 \\
\hline Other rigid products & 70 & 92 & 90 & 85 & 7.6 & 80 & 69 & 77 & 66 \\
\hline Fibers & 50 & 95 & 90 & 85 & 11 & 0 & - & $0^{c}$ & - \\
\hline \multicolumn{10}{|l|}{ Others } \\
\hline Soft, 2D products & 31 & 98 & 90 & 85 & 13 & 53 & 0 & 50 & $0^{c}$ \\
\hline Furniture & 31 & 98 & 90 & 85 & 13 & 55 & 0 & 51 & $0^{c}$ \\
\hline Other rigid products & 31 & 98 & 90 & 85 & 13 & 55 & 0 & 51 & $0^{c}$ \\
\hline
\end{tabular}

a) Assumed based on purity curve from Haupt et al. ${ }^{64}$

b) Assumed based on SE and RE for Other rigid packaging products

c) Values set to 0 in SO: Baseline, remains 0, as this describes recycling possibilities/routes, rather than efficiencies.

d) Assumed based on SE and RE for products within the Building and construction sector

\section{S4.6 State-of-the-art EOL technologies (S4)}

In this scenarios, the efficiency of the sorting and the reprocessing step are adjusted, to represent Stateof-the-art technology performance. However, even for State-of-the-art technology, the efficiency is expected to depend on the composition of the waste, and the complexity of product design in the waste. In Eriksen and Astrup (2019), the quantities of recycled PET, PE and PP potentially recovered in Denmark was assessed, based on a detailed waste composition of source-separated rigid plastic waste from Danish households ${ }^{8}$. As the detailed waste composition, allowed the study to take the effect of product design into consideration, the sorting and reprocessing efficiencies, applied in S4: State-of-the-art EOL technology, were estimated based on this ${ }^{8}$. This was done from the results of were the sorting and was assumed to be high, and where all black plastic is recoverable (requiring new technology). The applied values are presented in Table S4.6.

Moreover, all products in the Others sector were assumed recycled into other rigid products in that sector, with the efficiencies provided in the table. 
Table S4.6 Overview of applied sorting and reprocessing efficiencies in S1.4 - State-of-the-art EOL technologies.

\begin{tabular}{lcc}
\hline Flow & Sorting efficiency [\%] & Reprocessing efficiency [\%] \\
\hline All PET flows & 83 & 83 \\
All PE flows & 88 & 85 \\
All PP flows & 70 & 84 \\
\hline
\end{tabular}




\section{S5 Results: Sankey diagrams + flow values for year $n=1$ and $n=50$}

In this section, the following information is given for all scenarios:

- A sankey diagram of the total PET, PE and PP flows in year 1 and 50

- Detailed flow values in year 1 and 50, separated into PET, PE and PP

The detailed flow values are presented in tables, where different processes in the system are assigned a specific color, as given below

Trade/manufacturing
Use
Source-separation
Separate collection
Residual collection
Reprocessing
Final disposal (incineration or landfill)


S5.1 Baseline (S0)

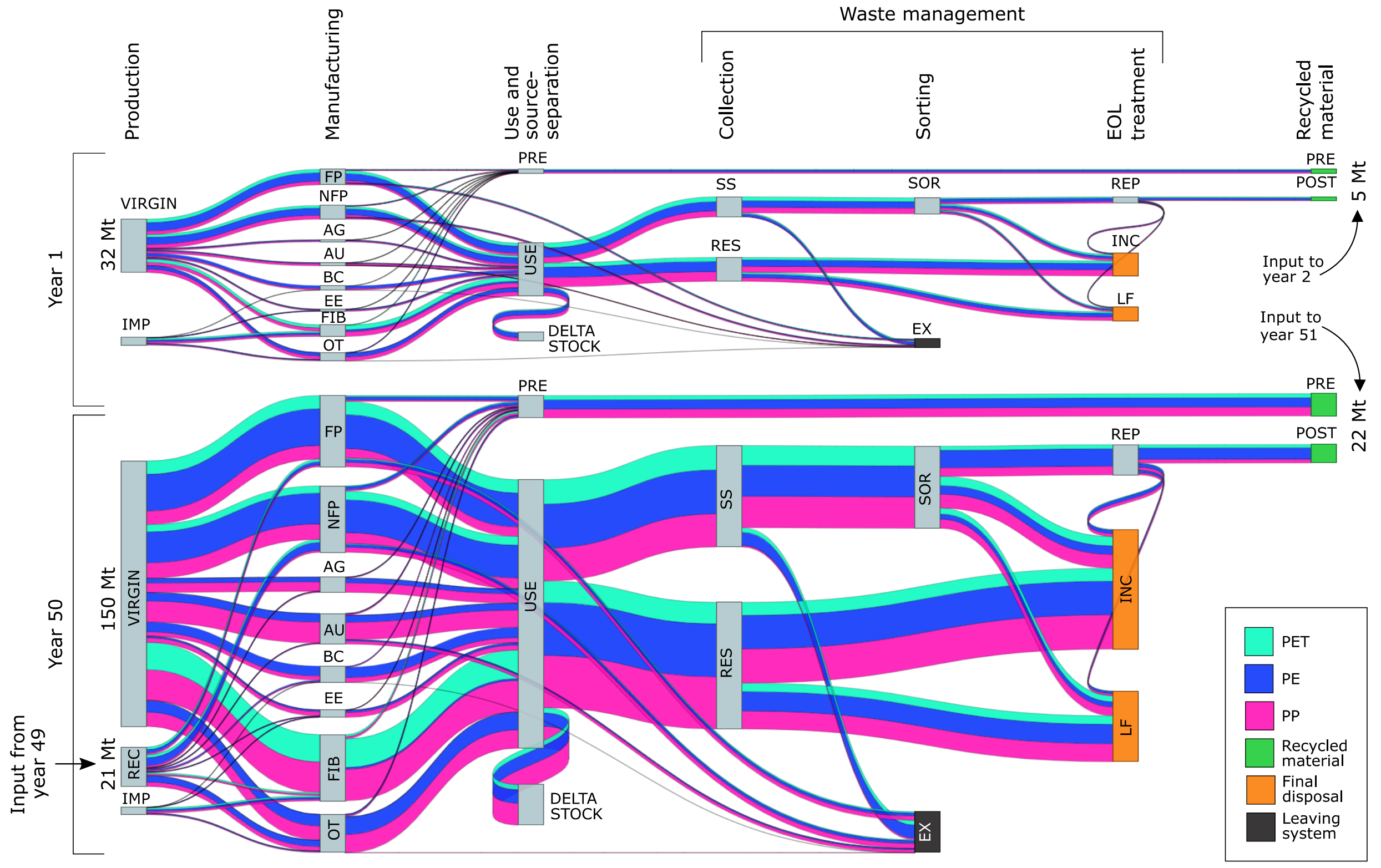

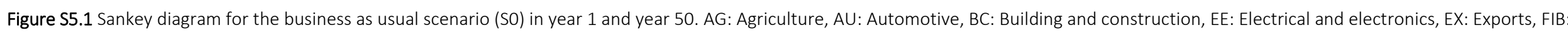

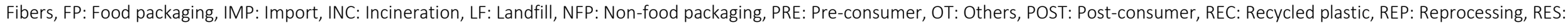
Residual waste, SOR: Sorting, SS: Source-separated waste. 


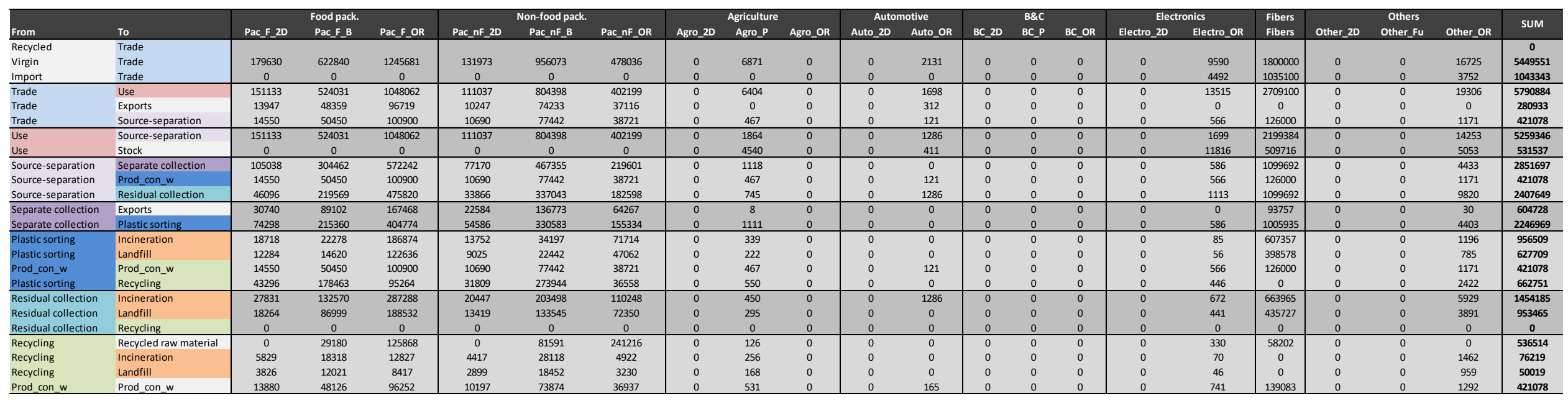

Table S5.2 Detailed PET flow values [ton] in year 50 in SO: Baseline. Prod_con_w: Pre-consumer waste. Flow abbreviations are provided in Table S1.1 and on page 53.

\begin{tabular}{|c|c|c|c|c|c|c|c|c|c|c|c|c|c|c|c|c|c|c|c|c|c|c|}
\hline & & & Food pack. & & & on-food pa & & & Agricultur & & Autor & motive & & B\&C & & Elec & tronics & Fibers & & Others & & \\
\hline From & To & Pac_F_2D & Pac_F_B & Pac_F_OR & Pac_nF_2D & Pac_nF_B & Pac_nF_OR & Agro_2t & D Agro_P & Agro_OR & R Auto_2D & Auto_OR & BC_2D & BC_P & BC_OR & Electro_2D & Electro_OR & Fibers & Other_2D & Other_Fu & Other_OR & SUIM \\
\hline Recycled & Trade & 77872 & 358970 & 1071806 & 57212 & 663210 & 1030508 & 0 & 6635 & 0 & 0 & 924 & 0 & 0 & 0 & 0 & 12689 & \begin{tabular}{|l|}
957761 \\
\end{tabular} & 0 & 0 & 7251 & 4244838 \\
\hline Virgin & Trade & 509786 & 1585382 & 5730796 & 374537 & 2321409 & 1580025 & 0 & 61638 & 0 & 0 & 20250 & 0 & 0 & 0 & 0 & 44758 & 16127203 & 0 & 0 & 81994 & 28437779 \\
\hline Import & Trade & 0 & 0 & 0 & 0 & 0 & 0 & 0 & 0 & 0 & 0 & 0 & 0 & 0 & 0 & 0 & 4492 & 1035100 & 0 & 0 & 3752 & 1043343 \\
\hline Trade & Use & 494431 & 1635893 & 5723416 & 363255 & 2511130 & 2196390 & 0 & 63630 & 0 & 0 & 16868 & 0 & 0 & 0 & 0 & 58549 & 16924117 & 0 & 0 & 86749 & 30074428 \\
\hline Trade & Exports & 45628 & 150966 & 528176 & 33522 & 231735 & 202690 & 0 & 0 & 0 & 0 & 3099 & 0 & 0 & 0 & 0 & 0 & 0 & 0 & 0 & 0 & 1195816 \\
\hline Trade & Source-separation & 47600 & 157492 & 551011 & 34972 & 241754 & 211453 & 0 & 4643 & 0 & 0 & 1207 & 0 & 0 & 0 & 0 & 3389 & 1195947 & 0 & 0 & 6247 & 2455716 \\
\hline Use & Source-separation & 494431 & 1635893 & 5723416 & 363255 & 2511130 & 2196390 & 0 & 56523 & 0 & 0 & 9373 & 0 & 0 & 0 & 0 & 45475 & 13934605 & 0 & 0 & 70231 & 27040722 \\
\hline Use & Stock & 0 & 0 & 0 & 0 & 0 & 0 & 0 & 7107 & 0 & 0 & 7495 & 0 & 0 & 0 & 0 & 13074 & 2989512 & 0 & 0 & 16519 & 3033706 \\
\hline Source-separation & Separate collection & 343629 & 950454 & 3124985 & 252462 & 1458966 & 1199229 & 0 & 33914 & 0 & 0 & 0 & 0 & 0 & 0 & 0 & 15689 & 6967303 & 0 & 0 & 21842 & 14368473 \\
\hline Source-separation & Residual collection & 150801 & 685439 & 2598431 & 110793 & 1052163 & 997161 & 0 & 22609 & 0 & 0 & 9373 & 0 & 0 & 0 & 0 & 29786 & 6967303 & 0 & 0 & 48389 & 12672249 \\
\hline Separate collection & Exports & 100564 & 278153 & 914536 & 73884 & 426971 & 350958 & 0 & 229 & 0 & 0 & 0 & 0 & 0 & 0 & 0 & 1 & 594016 & 0 & 0 & 147 & 2739458 \\
\hline Separate collection & Plastic sorting & 243065 & 672301 & 2210449 & 178578 & 1031996 & 848271 & 0 & 33685 & 0 & 0 & 0 & 0 & 0 & 0 & 0 & 15688 & 6373287 & 0 & 0 & 21694 & 11629015 \\
\hline Plastic sorting & Incineration & 61236 & 69546 & 1020508 & 44990 & 106754 & 391625 & 0 & 10271 & 0 & 0 & 0 & 0 & 0 & 0 & 0 & 2273 & 3848022 & 0 & 0 & 5894 & 5561120 \\
\hline Plastic sorting & Landfill & 40186 & 45639 & 669708 & 29525 & 70058 & 257004 & 0 & 6740 & 0 & 0 & 0 & 0 & 0 & 0 & 0 & 1492 & 2525264 & 0 & 0 & 3868 & 3649485 \\
\hline Prod_con_w & Prod_con_w & 47600 & 157492 & 551011 & 34972 & 241754 & 211453 & 0 & 4643 & 0 & 0 & 1207 & 0 & 0 & 0 & 0 & 3389 & $\mid 1195947$ & 0 & 0 & 6247 & 2455716 \\
\hline Plastic sorting & Recycling & 141642 & 557116 & 520233 & 104064 & 855184 & 199642 & 0 & 16674 & 0 & 0 & 0 & 0 & 0 & 0 & 0 & 11923 & 0 & 0 & 0 & 11932 & 2418410 \\
\hline Residual collection & Incineration & 91050 & 413850 & 1568864 & 66894 & 635268 & 602060 & 0 & 13651 & 0 & 0 & 9373 & 0 & 0 & 0 & 0 & 17984 & 4206673 & 0 & 0 & 29216 & 7654883 \\
\hline Residual collection & Landfill & 59751 & 271589 & 1029567 & 43899 & 416895 & 395102 & 0 & 8958 & 0 & 0 & 0 & 0 & 0 & 0 & 0 & 11802 & 2760629 & 0 & 0 & 19173 & 5017366 \\
\hline Residual collection & Recycling & 0 & 0 & 0 & 0 & 0 & 0 & 0 & 0 & 0 & 0 & 0 & 0 & 0 & 0 & 0 & 0 & 0 & 0 & 0 & 0 & 0 \\
\hline Recycling & Recycled raw material & 0 & 91094 & 548761 & 0 & 254708 & 845482 & 0 & 3835 & 0 & 0 & 0 & 0 & 0 & 0 & 0 & 8823 & 181692 & 0 & 0 & 0 & 1934395 \\
\hline Recycling & Landfill & 12515 & 37526 & 45967 & 9484 & 57604 & 17640 & 0 & 5087 & 0 & 0 & 0 & 0 & 0 & 0 & 0 & 1228 & 0 & 0 & 0 & 4728 & 191779 \\
\hline Prod_con_w & Prod_con_w & 80946 & 280669 & 561338 & 59471 & 430832 & 215416 & 0 & 3096 & 0 & 0 & 960 & 0 & 0 & 0 & 0 & 4321 & 811129 & 0 & 0 & 7537 & 2455716 \\
\hline
\end{tabular}




\begin{tabular}{|c|c|c|c|c|c|c|c|c|c|c|c|c|c|c|c|c|c|c|c|c|c|c|}
\hline From & To & Pac_F_2D & $\begin{array}{c}\text { Food pack. } \\
\text { Pac_F_B }\end{array}$ & Pac_F_OR & $\begin{array}{r}N \\
\text { Pac_nF_2D }\end{array}$ & $\begin{array}{l}\text { on-food pz } \\
\text { Pac_nF_B }\end{array}$ & ck. & Agro_2D & $\begin{array}{l}\text { Agricultt } \\
\text { Agro_ }\end{array}$ & Agro_or & $\begin{array}{r}\text { Aut } \\
\text { Auto_2 }\end{array}$ & $\begin{array}{l}\text { notive } \\
\text { Auto_OR }\end{array}$ & BC_2D & $\begin{array}{l}\text { B\&C } \\
\text { BC_P }\end{array}$ & BC_OR & $\begin{array}{r}\text { Elec } \\
\text { Electro_2 }\end{array}$ & $\begin{array}{l}\text { tronics } \\
\text { Electro_OR }\end{array}$ & \begin{tabular}{|l|} 
Fibers \\
Fibers
\end{tabular} & Other & $\begin{array}{c}\text { Others } \\
\text { Other_Fu }\end{array}$ & Other_OR & SUM \\
\hline Recycled & Trade & & & & & & & & & & & & & & & & & & & & & 0 \\
\hline Virgin & Trade & 4497128 & 397936 & 161611 & 2407793 & 1760749 & 118994 & 365360 & 77688 & 60790 & 0 & 517785 & 548048 & 1201236 & 0 & 0 & 421489 & 0 & 0 & 255741 & 1742712 & 14535062 \\
\hline Import & Trade & 0 & 0 & 0 & 0 & 0 & 0 & 0 & 0 & 0 & 0 & 0 & 6579 & 14421 & 0 & 0 & 197000 & 1035100 & 0 & 57378 & 390998 & 1701477 \\
\hline Trade & Use & 3797268 & 336008 & 136460 & 2033083 & 1486734 & 100476 & 340516 & 72405 & 56656 & 0 & 412484 & 516812 & 1132772 & 0 & 0 & 593621 & 1035100 & 0 & 295217 & 2011721 & 14357335 \\
\hline Trade & Exports & 335593 & 29696 & 12060 & 179679 & 131394 & 8880 & 0 & 0 & 0 & 0 & 75787 & 0 & 0 & 0 & 0 & 0 & 0 & 0 & 0 & 0 & 773088 \\
\hline Trade & Source-separation & 364267 & 32233 & 13090 & 195031 & 142621 & 9639 & 24844 & 5283 & 4134 & 0 & 29514 & 37815 & 82885 & 0 & 0 & 24868 & 0 & 0 & 17902 & 121990 & 1106116 \\
\hline Use & Source-separation & 3797267 & 336008 & 136460 & 2033083 & 1486734 & 100476 & 303062 & 65499 & 49178 & 0 & 177242 & 20233 & 45036 & 0 & 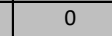 & 304765 & 840346 & 0 & 237430 & 1679990 & 11612809 \\
\hline Use & Stock & 1 & 0 & 0 & 1 & 0 & 0 & 37454 & 6906 & 7479 & 0 & 235242 & 496579 & 1087736 & 0 & 0 & 288856 & 194754 & 0 & 57787 & 331731 & 2744526 \\
\hline Source-separation & Separate collection & 2126469 & 149869 & 28873 & 1138526 & 663124 & 21259 & 181837 & 39299 & 29507 & 0 & 0 & 5564 & 10133 & 0 & 0 & 105144 & 420173 & 0 & 73841 & 522477 & 5516095 \\
\hline Source-separation & Residual collection & 1670797 & 186139 & 107587 & 894556 & 823610 & 79217 & 121225 & 26200 & 19671 & 0 & 177242 & 14669 & 34903 & 0 & 0 & 199621 & 420173 & 0 & 163589 & 1157513 & 6096714 \\
\hline Separate collection & Exports & 806511 & 56841 & 10951 & 431812 & 251504 & 8063 & 1569 & 339 & 255 & 0 & 0 & 0 & 0 & 0 & 0 & 9 & 0 & 0 & 637 & 4508 & 1572999 \\
\hline Separate collection & Plastic sorting & 1319958 & 93028 & 17922 & 706715 & 411619 & 13196 & 180268 & 38960 & 29252 & 0 & 0 & 5564 & 10133 & 0 & 0 & 105135 & 420173 & 0 & 73204 & 517969 & 3943096 \\
\hline Plastic sorting & Incineration & 332543 & 13430 & 10711 & 178046 & 59423 & 7886 & 60393 & 14526 & 13051 & 0 & 0 & 806 & 1307 & 0 & 0 & 46699 & 420173 & 0 & 22099 & 156368 & 1337461 \\
\hline Plastic sorting & Landfill & 218231 & 8813 & 7029 & 116842 & 38997 & 5175 & 39633 & 9532 & 8565 & 0 & 0 & 307 & 719 & 0 & 0 & 30646 & 0 & 0 & 14503 & 102616 & 601610 \\
\hline Prod_con_w & Prod_con_w & 364267 & 32233 & 13090 & 195031 & 142621 & 9639 & 24844 & 5283 & 4134 & 0 & 29514 & 37815 & 82885 & 0 & 0 & 24868 & 0 & 0 & 17902 & 121990 & 1106116 \\
\hline Plastic sorting & Recycling & 769184 & 70784 & 183 & 411827 & 313199 & 134 & 80242 & 14902 & 7636 & 0 & 0 & 4451 & 8106 & 0 & 0 & 27789 & 0 & 0 & 36602 & 258984 & 2004025 \\
\hline Residual collection & Incineration & 1002478 & 111684 & 64552 & 536734 & 494166 & 47530 & 72735 & 15720 & 11803 & 0 & 159518 & 10623 & 22518 & 0 & 0 & 119773 & 420173 & 0 & 98154 & 694508 & 3882668 \\
\hline Residual collection & Landfill & 668319 & 74456 & 43035 & 357823 & 329444 & 31687 & 48490 & 10480 & 7868 & 足 & 17724 & 4047 & 12385 & 0 & 促 & 79849 & 0 & 0 & 65436 & 463005 & 2214046 \\
\hline Residual collection & Recycling & 0 & 0 & 0 & 0 & 0 & 0 & 0 & 0 & 0 & 0 & 0 & 0 & 0 & 0 & 0 & 0 & 0 & 0 & 0 & 0 & 0 \\
\hline Recycling & Recycled raw material & 0 & 0 & 0 & 431439 & 177784 & 0 & 9228 & 3428 & 1756 & 0 & 0 & 1692 & 3080 & 0 & 0 & 24455 & 0 & 0 & 150062 & 454959 & 1257883 \\
\hline Recycling & Landfill & 86860 & 2075 & 14 & 46505 & 9183 & 11 & 24481 & 4547 & 2330 & 0 & 0 & 295 & 690 & 0 & 0 & 1321 & 0 & 0 & 14503 & 102616 & 295432 \\
\hline Prod_con_w & Prod_con_w & 364267 & 32233 & 13090 & 195031 & 142621 & 9639 & 24844 & 5283 & 4134 & 0 & 29514 & 37815 & 82885 & 0 & 0 & 24868 & 0 & 0 & 17902 & 121990 & 1106116 \\
\hline
\end{tabular}

Table S5.4 Detailed PE flow values [ton] in year 50 in SO: Baseline. Prod_con_w: Pre-consumer waste. Flow abbreviations are provided in Table S1.1 and on page 53.

\begin{tabular}{|c|c|c|c|c|c|c|c|c|c|c|c|c|c|c|c|c|c|c|c|c|c|c|}
\hline \multirow[b]{2}{*}{ From } & \multirow[b]{2}{*}{ To } & \multicolumn{3}{|c|}{ Food pack. } & \multicolumn{3}{|c|}{ Non-food pack. } & \multicolumn{3}{|c|}{ Agriculture } & \multirow{2}{*}{\multicolumn{2}{|c|}{$\begin{array}{l}\text { Automotive } \\
\text { ato 2D Auto OR }\end{array}$}} & \multicolumn{3}{|c|}{$B \& C$} & \multirow{2}{*}{\multicolumn{2}{|c|}{$\begin{array}{l}\text { Electronics } \\
\text { ro 2D Electro OR }\end{array}$}} & \multirow{2}{*}{$\begin{array}{l}\text { Fibers } \\
\text { Fibers }\end{array}$} & \multirow{2}{*}{\multicolumn{3}{|c|}{$\begin{array}{c}\text { Others } \\
\text { Other_2D Other_Fu }\end{array}$}} & \multirow{2}{*}{ SUM } \\
\hline & & Pac_F_2D & Pac_F_B & Pac_F_OR & Pac_nF_2D & Pac_nF_B & Pac_nF_OF & Agro_2D & Agro_P & Agro_OR & & & BC_2D & BC_P & BC_OR & & & & & & & \\
\hline Recycled & Trade & 1769076 & 156540 & 63574 & 2857289 & 1815851 & 46810 & 175208 & 45590 & 30721 & 0 & 143334 & 245600 & 513665 & 0 & 0 & 211828 & 0 & 0 & 831913 & 3000442 & 11907440 \\
\hline Virgin & Trade & 18627664 & 2458112 & 669411 & 8063265 & 9753199 & 492889 & 2013532 & 419809 & 333451 & 0 & 5001519 & 1817348 & 4007996 & 0 & 0 & 986097 & 0 & 0 & 532685 & 6298439 & 61475418 \\
\hline Import & Trade & 0 & 0 & 0 & 0 & 0 & 0 & 0 & 0 & 0 & 0 & 0 & 6579 & 14421 & 0 & 0 & 197000 & 1035100 & 0 & 57378 & 390998 & 1701477 \\
\hline Trade & Exports & 1522083 & 195115 & 54698 & 4934 & 863327 & 40274 & 0 & 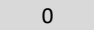 & 0 & 0 & 753041 & 0 & 0 & 0 & 0 & 0 & 0 & 0 & 0 & 0 & 4243473 \\
\hline Trade & Source-separation & 1652136 & 211787 & 59372 & 884565 & 937093 & 43716 & 148834 & 31647 & 24764 & 0 & 293257 & 142343 & 311995 & 0 & 0 & 70678 & 0 & 0 & 95522 & 650922 & 5558629 \\
\hline Use & Source-separation & 17222521 & 2207750 & 618915 & 9221056 & 9768630 & 455709 & 1859597 & 395413 & 309408 & 0 & 2277459 & 761526 & 1669520 & 0 & 0 & 1155422 & 1035100 & 0 & 1073876 & 7317794 & 57349694 \\
\hline Use & Stock & 0 & 0 & 0 & 0 & 0 & 0 & 180308 & 38340 & 30001 & 0 & 1821097 & 1165658 & 2554568 & 0 & 0 & 168825 & 0 & 0 & 252578 & 1721163 & 7932538 \\
\hline Source-separation & Separate collection & 9644612 & 984716 & 130952 & 5163791 & 4357073 & 96420 & 1115758 & 237248 & 185645 & 0 & 0 & 209420 & 375642 & 0 & 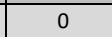 & 398621 & \begin{tabular}{|l|}
517550 \\
\end{tabular} & 0 & 333976 & 2275834 & 26027256 \\
\hline Source-separation & Residual collection & 7577909 & 1223034 & 487963 & 4057264 & 5411557 & 359289 & 743839 & 158165 & 123763 & 0 & 2277459 & 552106 & 1293878 & 0 & 0 & 756801 & 517550 & 0 & 739901 & 5041960 & 31322439 \\
\hline Separate collection & Exports & 3657934 & 373476 & 49666 & 1958483 & 1652517 & 36569 & 9627 & 2047 & 1602 & 0 & 0 & 0 & 0 & 0 & 0 & 35 & 0 & 0 & 2882 & 19637 & 7764476 \\
\hline Separate collection & Plastic sorting & 5986677 & 611240 & 81285 & 3205308 & 2704556 & 59851 & 1106131 & 235201 & 184043 & 0 & 0 & 209420 & 375642 & 0 & 0 & 398585 & 517550 & 0 & 331094 & 2256197 & 18262779 \\
\hline Plastic sorting & Incineration & 1508249 & 88242 & 48578 & 807527 & 390443 & 35768 & 370573 & 87690 & 82114 & 0 & 0 & 30330 & 48470 & 0 & 0 & 177045 & \begin{tabular}{|l|}
517550 \\
\end{tabular} & 0 & 99953 & 681116 & 4973648 \\
\hline Plastic sorting & Landfill & 989789 & 57909 & 31879 & 529940 & 256228 & 23473 & 243189 & 57547 & 53887 & 0 & 0 & 11554 & 26658 & 0 & 0 & 116186 & 0 & 0 & 65594 & 446982 & 2910814 \\
\hline Prod_con_w & Prod_con_w & 1652136 & 211787 & 59372 & 884565 & 937093 & 43716 & 148834 & 31647 & 24764 & 0 & 293257 & 142343 & 311995 & 0 & 0 & 70678 & 0 & 0 & 95522 & 650922 & 5558629 \\
\hline Plastic sorting & Recycling & 3488639 & 465090 & 828 & 1867841 & 2057885 & 610 & 492369 & 89964 & 48042 & 0 & 0 & 167536 & 300513 & O & O & 105354 & 0 & 0 & 165547 & 1128098 & 10378317 \\
\hline Residual collection & Incineration & 4546745 & 733820 & 292778 & 2434359 & 3246934 & 215573 & 446303 & 94899 & 74258 & 0 & 2049713 & 399801 & 834760 & 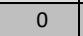 & 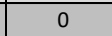 & 454081 & 517550 & 0 & 443940 & 3025176 & 19810691 \\
\hline Residual collection & Landfill & 3031164 & 489213 & 195185 & 1622906 & 2164623 & 143716 & 297535 & 63266 & 49505 & 0 & 227746 & 152305 & 459118 & 0 & 0 & 302721 & 0 & 0 & 295960 & 2016784 & 11511747 \\
\hline Residual collection & Recycling & 0 & 0 & 0 & 0 & 0 & 0 & 0 & 0 & 0 & 0 & 0 & 0 & 0 & 0 & 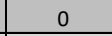 & 0 & 0 & 0 & 0 & 0 & 0 \\
\hline Recycling & Recycled raw material & 0 & 0 & 0 & 1971564 & 1168138 & 0 & 56622 & 20692 & 11050 & 0 & 0 & 63664 & 114195 & 0 & 0 & 92712 & 0 & 0 & 771057 & 2491031 & 6760724 \\
\hline Recycling & Landfill & 393953 & 13637 & 66 & 210925 & 60339 & 48 & 150219 & 27448 & 14657 & 0 & 0 & 11092 & 25592 & 0 & 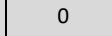 & 5009 & 0 & 0 & 65594 & 446982 & 1425561 \\
\hline Prod_con_w & Prod_con_w & 1830574 & 161982 & 65784 & 980102 & 716720 & 48437 & 124852 & 26548 & 20773 & 0 & 148317 & 190036 & 416528 & 0 & 0 & 124970 & 0 & 0 & 89963 & 613043 & 5558629 \\
\hline
\end{tabular}




\begin{tabular}{|c|c|c|c|c|c|c|c|c|c|c|c|c|c|c|c|c|c|c|c|c|c|c|}
\hline \multirow[b]{2}{*}{ From } & \multirow[b]{2}{*}{ To } & \multicolumn{3}{|c|}{ Food pack. } & \multicolumn{3}{|c|}{ Non-food pack. } & \multicolumn{3}{|c|}{ Agriculture } & \multirow{2}{*}{\multicolumn{2}{|c|}{$\begin{array}{c}\text { Automotive } \\
\text { Auto_2D Auto_OR }\end{array}$}} & \multicolumn{3}{|c|}{$B \& C$} & \multicolumn{2}{|c|}{ Electronics } & \multirow{3}{*}{\begin{tabular}{|l|} 
Fibers \\
Fibers \\
\end{tabular}} & \multicolumn{3}{|c|}{ Others } & \multirow{2}{*}{ SUM } \\
\hline & & Pac_F_2D & Pac_F_B & Pac_F_OR & Pac_nF_2 & Pac_nF_E & Pac_nF_OF & Agro_2 & 2D Agro & P Agro_OR & & & BC_2D & BC_P & BC_OR & Electro_2 & Electro_OR & & Other__2 & Other_Fu & Other_OR & \\
\hline Recycled & Trade & & & & & & & & & & & & & & & & & & & & & 0 \\
\hline Virgin & Trade & 791484 & 0 & 1244000 & 878460 & 921948 & 461000 & 0 & 0 & 607764 & 0 & 1298633 & 0 & 792627 & 0 & 0 & 482876 & 2000000 & 0 & 177481 & 1879215 & 11535489 \\
\hline Import & Trade & 0 & 0 & 0 & 0 & 0 & 0 & 0 & 0 & 0 & 0 & 0 & 0 & 9000 & 0 & 0 & 226000 & 1035100 & 0 & 39780 & 421200 & 1731080 \\
\hline Trade & Use & 495870 & 0 & 779444 & 550361 & 577607 & 288827 & 0 & 0 & 566436 & 0 & 1034611 & 0 & 755936 & 0 & 0 & 680387 & 2895100 & 0 & 244618 & 2168870 & 11038065 \\
\hline Trade & Exports & 231504 & 0 & 363792 & 256944 & 269664 & 134832 & 0 & 0 & 0 & 0 & 190000 & 0 & -9000 & 0 & 0 & 0 & 0 & 0 & -39780 & 0 & 1397956 \\
\hline Trade & Source-separation & 64110 & 0 & 100764 & 71155 & 74678 & 37341 & 0 & 0 & 41328 & 0 & 74022 & 0 & 54691 & 0 & 0 & 28490 & 140000 & 0 & 12424 & 131545 & 830548 \\
\hline Use & Source-separation & 495870 & 0 & 779444 & 550361 & 577606 & 288827 & 0 & 0 & 701299 & 0 & 593697 & 0 & 28755 & 0 & 0 & 420235 & 2350388 & 0 & 205990 & 2053593 & 9046065 \\
\hline Use & Stock & 0 & 0 & 0 & 0 & 0 & 0 & 0 & 0 & -134863 & 0 & 440914 & 0 & 727180 & 0 & 0 & 260151 & 544712 & 0 & 38628 & 115277 & 1992000 \\
\hline Source-separation & Separate collection & 344629 & 0 & 0 & 382501 & 258768 & 0 & 0 & 0 & 420779 & 0 & 0 & 0 & 20129 & 0 & 0 & 144981 & 1175194 & 0 & 64063 & 638667 & 3449711 \\
\hline Source-separation & Residual collection & 151240 & 0 & 779444 & 167860 & 318839 & 288827 & 0 & 0 & 280519 & 0 & 593697 & 0 & 8627 & 0 & 0 & 275254 & 1175194 & 0 & 141927 & 1414925 & 5596354 \\
\hline Separate collection & Exports & 56366 & 0 & 0 & 62561 & 42323 & 0 & 0 & 0 & 1566 & 0 & 0 & 0 & 0 & 0 & 0 & 6 & 21548 & 0 & 238 & 2376 & 186985 \\
\hline Separate collection & Plastic sorting & 288263 & 0 & 0 & 319940 & 216444 & 0 & 0 & 0 & 419213 & 0 & 0 & 0 & 20129 & 0 & 0 & 144976 & 1153646 & 0 & 63825 & 636291 & 3262727 \\
\hline Plastic sorting & Incineration & 72623 & 0 & 0 & 80604 & 72869 & 0 & 0 & 0 & 187039 & 0 & 0 & 0 & 2629 & 0 & 0 & 76790 & 696541 & 0 & 17341 & 172879 & 1379316 \\
\hline Plastic sorting & Landfill & 47659 & 0 & 0 & 52896 & 47820 & 0 & 0 & 0 & 122745 & 0 & 0 & 0 & 1397 & 0 & 0 & 50394 & 457105 & 0 & 11380 & 113452 & 904848 \\
\hline Prod_con_w & Prod_con_w & 64110 & 0 & 100764 & 71155 & 74678 & 37341 & 0 & 0 & 41328 & 0 & 74022 & 0 & 54691 & 0 & 0 & 28490 & 140000 & 0 & 12424 & 131545 & 830548 \\
\hline Plastic sorting & Recycling & 167981 & 0 & 0 & 186440 & 95755 & 0 & 0 & 0 & 109429 & 0 & 0 & 0 & 16103 & 0 & 0 & 17791 & 0 & 0 & 35104 & 349960 & 978563 \\
\hline Residual collection & Incineration & 90744 & 0 & 467666 & 100716 & 191303 & 173296 & 0 & 0 & 168312 & 0 & 534328 & 0 & 5634 & 0 & 0 & 165152 & 709551 & 0 & 85156 & 848955 & 3540814 \\
\hline Residual collection & Landfill & 60496 & 0 & 311778 & 67144 & 127536 & 115531 & 0 & 0 & 112208 & 0 & 59370 & 0 & 2993 & 0 & 0 & 110102 & 465643 & 0 & 56771 & 565970 & 2055540 \\
\hline Residual collection & Recycling & 0 & 0 & 0 & 0 & 0 & 0 & 0 & 0 & 0 & 0 & 0 & 0 & 0 & 0 & 0 & 0 & 0 & 0 & 0 & 0 & 0 \\
\hline Recycling & Recycled raw material & 0 & 0 & 0 & 0 & 0 & 0 & 0 & 0 & 25169 & 0 & 0 & 0 & 5556 & 0 & 0 & 14767 & 0 & 0 & 82743 & 253785 & 382019 \\
\hline Recycling & Landfill & 18969 & 0 & 0 & 21054 & 7209 & 0 & 0 & 0 & 33386 & 0 & 0 & 0 & 1732 & 0 & 0 & 1198 & 0 & 0 & 13909 & 138663 & 236120 \\
\hline Prod_con_w & Prod_con_w & 64112 & 0 & 100747 & 71157 & 74680 & 37340 & 0 & 0 & 41329 & 0 & 74024 & 0 & 54693 & 0 & 0 & 28490 & 140004 & 0 & 12424 & 131548 & 830548 \\
\hline
\end{tabular}

Table S5.6 Detailed PP flow values [ton] in year 50 in SO: Baseline. Prod_con_w: Pre-consumer waste. Flow abbreviations are provided in Table S1.1 and on page 53.

\begin{tabular}{|c|c|c|c|c|c|c|c|c|c|c|c|c|c|c|c|c|c|c|c|c|c|c|}
\hline \multirow[b]{2}{*}{ From } & \multirow[b]{2}{*}{ To } & \multicolumn{3}{|c|}{ Food pack. } & \multirow{2}{*}{\multicolumn{3}{|c|}{ Non-food pack. }} & \multicolumn{3}{|c|}{ Agriculture } & \multirow{2}{*}{\multicolumn{2}{|c|}{$\begin{array}{c}\text { Automotive } \\
\text { Auto 2D Auto OR }\end{array}$}} & \multicolumn{3}{|c|}{$B \& C$} & \multicolumn{2}{|c|}{ Electronics } & \multirow{2}{*}{$\begin{array}{l}\text { Fibers } \\
\text { Fibers }\end{array}$} & \multirow{2}{*}{\multicolumn{3}{|c|}{\begin{tabular}{|c|}
\multicolumn{1}{c|}{ Others } \\
Other_2D Other_Fu Other_OR
\end{tabular}}} & \multirow{2}{*}{ sum } \\
\hline & & Pac_F_2D & Pac_F_B & Pac_F_OR & & & & Agro_2D & D Agro_- & P Agro_OR & & & BC_2D & BC_P & BC_OR & Electro_2D & Electro_OR & & & & & \\
\hline Recycled & Trade & 383623 & 0 & 602837 & 425780 & 446858 & 223429 & 0 & 0 & 418349 & 0 & 442934 & 0 & 536611 & 0 & 0 & 248282 & 837734 & 0 & 437986 & 2087425 & 7091849 \\
\hline Virgin & Trade & 3206155 & 0 & 4782791 & 3558480 & 3734642 & 1772370 & 0 & 0 & 5620555 & 0 & 12460640 & 0 & 2446973 & 0 & 0 & 2644455 & 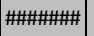 & 0 & 509031 & 7939814 & 66821465 \\
\hline Import & Trade & 0 & 0 & 0 & 0 & 0 & 0 & 0 & 0 & 0 & 0 & 0 & 0 & 9000 & 0 & 0 & 226000 & 1035100 & 0 & 39780 & 421200 & 1731080 \\
\hline Trade & Use & 2249019 & 0 & 3374433 & 2496164 & 2619737 & 1250414 & 0 & 0 & 5628259 & 0 & 10280179 & 0 & 2820594 & 0 & 0 & 2948066 & 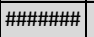 & 0 & 1132767 & 9746532 & 63235727 \\
\hline Trade & Exports & $\mid 1049987$ & 0 & 1574958 & 1165370 & 1223062 & 583726 & 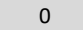 & 0 & 0 & 0 & 1887892 & 0 & -33878 & 0 & 0 & 0 & 0 & 0 & -212261 & 0 & 7238857 \\
\hline Trade & Source-separation & 290772 & 0 & 436236 & 322725 & 338702 & 161660 & 0 & 0 & 410645 & 0 & 735504 & 0 & 205867 & 0 & 0 & \begin{tabular}{l|l}
170672 & 1
\end{tabular} & 1328831 & 0 & 66291 & 701907 & 5169811 \\
\hline Use & Source-separation & 2249019 & 0 & 3374433 & 2496164 & 2619737 & 1250414 & 0 & 0 & 4999660 & 0 & 5712424 & 0 & 1113751 & 0 & 0 & 2289721 & \#\#\#\#\#\#| & 0 & 915235 & 7890554 & 50278996 \\
\hline Use & Stock & 0 & 0 & 0 & 0 & 0 & 0 & 0 & 0 & 628598 & 0 & 4567755 & 0 & 1706843 & 0 & 0 & 658344 & 3321680 & 0 & 217532 & 1855978 & 12956731 \\
\hline Source-separation & Separate collection & 1563068 & 0 & 0 & 1734834 & 1173642 & 0 & 0 & 0 & 2999796 & 0 & 0 & 0 & 779626 & 0 & 0 & \begin{tabular}{l|l}
789954 & 7
\end{tabular} & \begin{tabular}{|l|}
7683942 \\
\end{tabular} & 0 & 284638 & 2453962 & 19463463 \\
\hline Source-separation & Residual collection & 685951 & 0 & 3374433 & 761330 & 1446095 & 1250414 & 0 & 0 & 1999864 & 0 & 5712424 & 0 & 334125 & 0 & 0 & 14997677 & 7683942 & 0 & 630597 & 5436592 & 30815534 \\
\hline Separate collection & Exports & 255650 & 0 & 0 & 283744 & 191957 & 0 & 0 & 0 & 11162 & 0 & 0 & 0 & 0 & 0 & 0 & 30 & 140892 & 0 & 1059 & 9131 & 893626 \\
\hline Separate collection & Plastic sorting & 1307418 & 0 & 0 & 1451090 & 981685 & 0 & 0 & 0 & 2988634 & 0 & 0 & 0 & 779626 & 0 & 0 & \begin{tabular}{l|l}
789924 & 7 \\
\end{tabular} & 7543049 & 0 & 283579 & 2444831 & 18569837 \\
\hline Plastic sorting & Incineration & 329383 & 0 & 0 & 365579 & 330497 & 0 & 0 & 0 & 1333432 & 0 & 0 & 0 & 101829 & 0 & 0 & \begin{tabular}{l|l}
418406 & 4
\end{tabular} & \begin{tabular}{|l|}
4554294 \\
\end{tabular} & 0 & 77048 & (664256 & 8174724 \\
\hline Plastic sorting & Landfill & 216158 & 0 & 0 & 239911 & 216889 & 0 & 0 & 0 & 875065 & 0 & 0 & 0 & 54096 & 0 & 0 & \begin{tabular}{l|l}
274579 & 2
\end{tabular} & 2988755 & 0 & 50563 & 435918 & 5351934 \\
\hline Prod_con_w & Prod_con_w & 290772 & 0 & 436236 & 322725 & 338702 & 161660 & 0 & 0 & 410645 & 0 & 735504 & 0 & 205867 & 0 & 0 & 170672 & 1328831 & 0 & 66291 & 701907 & 5169811 \\
\hline Plastic sorting & Recycling & 761877 & 0 & 0 & 845599 & 434299 & 0 & 0 & 0 & 780138 & 0 & 0 & 0 & 623701 & 0 & 0 & 96939 & 0 & 0 & 155968 & 1344657 & 5043178 \\
\hline Residual collection & Incineration & 411571 & 0 & 2024660 & 456798 & 867657 & 750248 & 0 & 0 & 1199918 & 0 & 5141182 & 0 & 218204 & 0 & 0 & \begin{tabular}{l|l|}
899860 & 4
\end{tabular} & 4639361 & 0 & 378358 & 3261955 & 20249773 \\
\hline Residual collection & Landfill & 274380 & 0 & 1349773 & 304532 & 578438 & 500165 & 0 & 0 & 799946 & 0 & 571242 & 0 & 115921 & 0 & 0 & \begin{tabular}{l|l}
599907 & 3
\end{tabular} & 3044581 & 0 & 252239 & 2174637 & 10565761 \\
\hline Residual collection & Recycling & 0 & 0 & 0 & 0 & 0 & 0 & 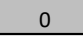 & 0 & 0 & 0 & 0 & 0 & 0 & 0 & 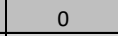 & 0 & 0 & 0 & 0 & 0 & 0 \\
\hline Recycling & Recycled raw material & 0 & 0 & 0 & 0 & 0 & 0 & 0 & 0 & 179432 & 0 & 0 & 0 & 215177 & 0 & 0 & 80460 & 0 & 0 & 375282 & 1341022 & 2191372 \\
\hline Recycling & Landfill & 86035 & 0 & 0 & 95489 & 32695 & 0 & 0 & 0 & 238016 & 0 & 0 & 0 & 67080 & 0 & 0 & 6530 & 0 & 0 & 61799 & 532789 & 1120431 \\
\hline Prod_con_w & Prod_con_w & 399069 & 0 & 627109 & 442923 & 464850 & 232425 & 0 & 0 & 257256 & 0 & 460768 & 0 & 340439 & 0 & 0 & 177341 & 871463 & 0 & 77334 & 818833 & 5169811 \\
\hline
\end{tabular}




\section{S5.2 Constant demand (S1a)}

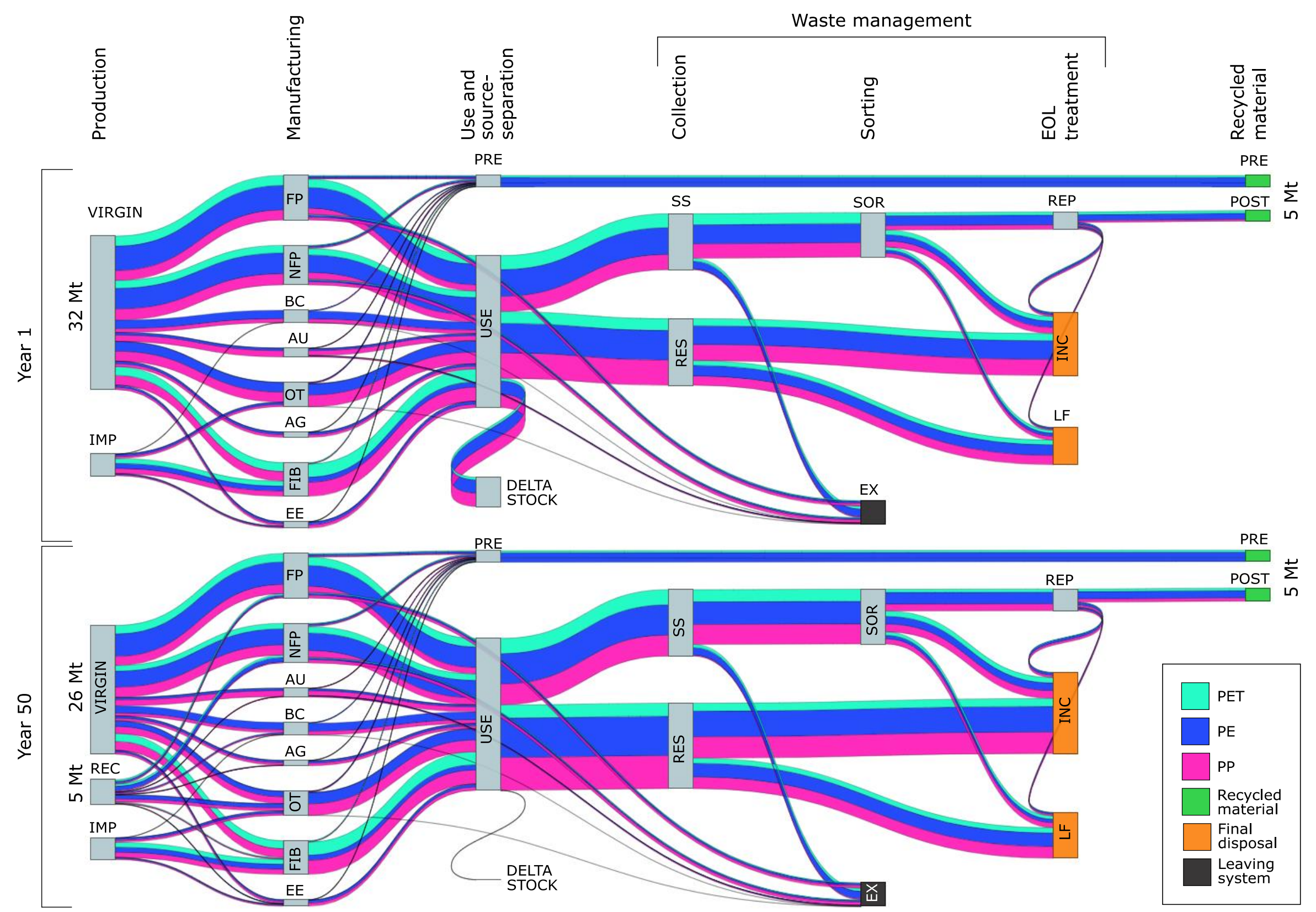

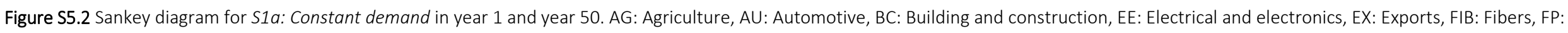

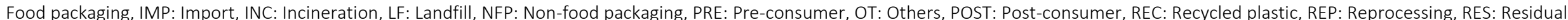
waste, SOR: Sorting, SS: Source-separated waste. 


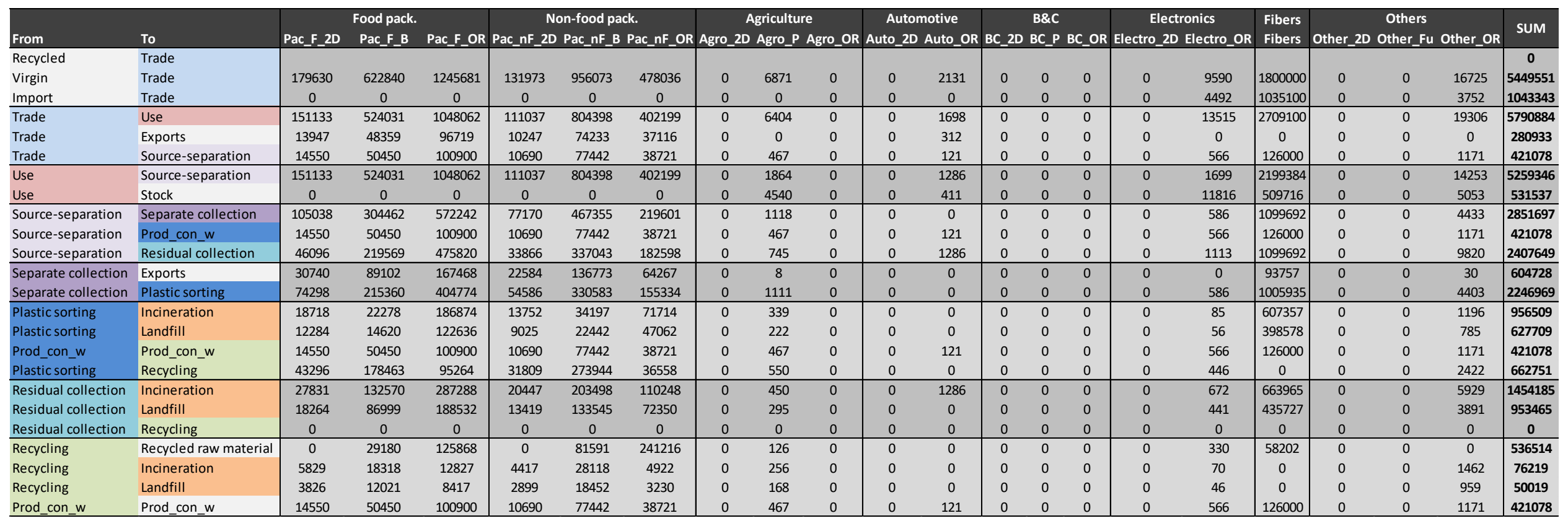

Table S5.8 Detailed PET flow values [ton] in year 50 in S1a: Constant demand. Prod_con_w: Pre-consumer waste. Flow abbreviations are provided in Table S1.1 and on page 53.

\begin{tabular}{|c|c|c|c|c|c|c|c|c|c|c|c|c|c|c|c|c|c|c|c|c|c|c|}
\hline \multirow[b]{2}{*}{ From } & \multirow[b]{2}{*}{ To } & \multicolumn{3}{|c|}{ Food pack. } & \multicolumn{3}{|c|}{ Non-food pack. } & \multicolumn{3}{|c|}{ Agriculture } & \multicolumn{2}{|c|}{ Automotive } & \multicolumn{3}{|c|}{ B\&C } & \multicolumn{2}{|c|}{ Electronics } & \multirow{2}{*}{$\begin{array}{l}\text { Fibers } \\
\text { Fibers } \\
\end{array}$} & \multirow{2}{*}{\multicolumn{3}{|c|}{$\begin{array}{c}\text { Others } \\
\text { Other 2D Other Fu Other OR }\end{array}$}} & \multirow{2}{*}{ SUM } \\
\hline & & Pac_F_2D & Pac_F_B & Pac_F_OR & Pac_nF_2D & Pac_nF_B & Pac_nF_OF & Agro_2t & D Agro_P & Agro_OR & Auto_2D & D Auto_OR & BC_2D & BC_P & BC_OR & E Electro_2D & Electro_OR & & & & & \\
\hline Recycled & Trade & 14550 & 79631 & 226768 & 10690 & 159033 & 279937 & 0 & 902 & 0 & 0 & 121 & 0 & 0 & 0 & 0 & 3188 & 184202 & 0 & 0 & 1171 & 960192 \\
\hline Virgin & Trade & 165080 & 543210 & 1018913 & 121283 & 797040 & 198100 & 0 & 5969 & 0 & 0 & 2010 & 0 & 0 & 0 & 0 & 6402 & $\mid 1615798$ & 0 & 0 & 15555 & 4489359 \\
\hline Import & Trade & 0 & 0 & 0 & 0 & 0 & 0 & 0 & 0 & 0 & 0 & 0 & 0 & 0 & 0 & 0 & 4492 & 1035100 & 0 & 0 & 3752 & 1043343 \\
\hline Trade & Use & 151133 & 524031 & 1048062 & 111037 & 804398 & 402199 & 0 & 6404 & 0 & 0 & 1698 & 0 & 0 & 0 & 0 & 13515 & \begin{tabular}{|l|}
2709100 \\
\end{tabular} & 0 & 0 & 19306 & 5790884 \\
\hline Trade & Exports & 13947 & 48359 & 96719 & 10247 & 74233 & 37116 & 0 & 0 & 0 & 0 & 312 & 0 & 0 & 0 & 0 & 0 & 0 & 0 & 0 & 0 & 280933 \\
\hline Trade & Source-separation & 14550 & 50450 & 100900 & 10690 & 77442 & 38721 & 0 & 467 & 0 & 0 & 121 & 0 & 0 & 0 & 0 & 566 & 126000 & 0 & 0 & 1171 & 421078 \\
\hline Use & Source-separation & 151133 & 524031 & 1048062 & 111037 & 804398 & 402199 & 0 & 6404 & 0 & 0 & 1698 & 0 & 0 & 0 & 0 & 13515 & \begin{tabular}{|l|}
2709100 \\
\end{tabular} & 0 & 0 & 19306 & \begin{tabular}{|l|}
5790884 \\
\end{tabular} \\
\hline Use & Stock & 0 & 0 & 0 & 0 & 0 & 0 & 0 & 0 & 0 & 0 & 0 & 0 & 0 & 0 & 0 & 0 & 0 & 0 & 0 & 0 & 0 \\
\hline Source-separation & Separate collection & 105038 & 304462 & 572242 & 77170 & 467356 & 219601 & 0 & 3842 & 0 & 0 & 0 & 0 & 0 & 0 & 0 & 4663 & 1354550 & 0 & 0 & 6004 & 3114928 \\
\hline Source-separation & Residual collection & 46096 & 219569 & 475820 & 33866 & 337043 & 182598 & 0 & 2562 & 0 & 0 & 1698 & 0 & 0 & 0 & 0 & 8853 & 1354550 & 0 & 0 & 13302 & 2675956 \\
\hline Separate collection & Exports & 30740 & 89102 & 167468 & 22584 & 136773 & 64267 & 0 & 26 & 0 & 0 & 0 & 0 & 0 & 0 & 0 & 0 & 115486 & 0 & 0 & 41 & 626486 \\
\hline Separate collection & Plastic sorting & 74298 & 215360 & 404774 & 54586 & 330583 & 155334 & 0 & 3816 & 0 & 0 & 0 & 0 & 0 & 0 & 0 & 4662 & 1239064 & 0 & 0 & 5964 & 2488442 \\
\hline Plastic sorting & Incineration & 18718 & 22278 & 186874 & 13752 & 34197 & 71714 & 0 & 1164 & 0 & 0 & 0 & 0 & 0 & 0 & 0 & 676 & 748114 & 0 & 0 & 1620 & 1099106 \\
\hline Plastic sorting & Landfill & 12284 & 14620 & 122636 & 9025 & 22442 & 47062 & 0 & 764 & 0 & 0 & 0 & 0 & 0 & 0 & 0 & 443 & 490950 & 0 & 0 & 1063 & 721289 \\
\hline Prod_con_w & Prod_con_w & 14550 & 50450 & 100900 & 10690 & 77442 & 38721 & 0 & 467 & 0 & 0 & 121 & 0 & 0 & 0 & 0 & 566 & 126000 & 0 & 0 & 1171 & 421078 \\
\hline Plastic sorting & Recycling & 43296 & 178463 & 95264 & 31809 & 273944 & 36558 & 0 & 1889 & 0 & 0 & 0 & 0 & 0 & 0 & 0 & 3543 & 0 & 0 & 0 & 3280 & 668047 \\
\hline Residual collection & Incineration & 27831 & 132570 & 287288 & 20447 & 203498 & 110248 & 0 & 1547 & 0 & 0 & 1698 & 0 & 0 & 0 & 0 & 5345 & 817842 & 0 & 0 & 8031 & 1616344 \\
\hline Residual collection & Landfill & 18264 & 86999 & 188533 & 13419 & 133545 & 72350 & 0 & 1015 & 0 & 0 & 0 & 0 & 0 & 0 & 0 & 3508 & 536708 & 0 & 0 & 5271 & 1059612 \\
\hline Residual collection & Recycling & 0 & 0 & 0 & 0 & 0 & 0 & 0 & 0 & 0 & 0 & 0 & 0 & 0 & 0 & 0 & 0 & 0 & 0 & 0 & 0 & 0 \\
\hline Recycling & Landfill & 3826 & 12021 & 8417 & 2899 & 18452 & 3230 & 0 & 576 & 0 & 0 & 0 & 0 & 0 & 0 & 0 & 365 & 0 & 0 & 0 & 1300 & 51086 \\
\hline Prod_con_w & Prod_con_w & 14550 & 50450 & 100900 & 10690 & 77442 & 38721 & 0 & 467 & 0 & 0 & 121 & 0 & 0 & 0 & 0 & 566 & 126000 & 0 & 0 & 1171 & 421078 \\
\hline
\end{tabular}




\begin{tabular}{|c|c|c|c|c|c|c|c|c|c|c|c|c|c|c|c|c|c|c|c|c|c|c|}
\hline From & To & Pac_F_2D & $\begin{array}{l}\text { Food pack. } \\
\text { Pac_F_B }\end{array}$ & Pac_F_OR & $\begin{array}{r}N \\
\text { Pac_nF_2D }\end{array}$ & $\begin{array}{l}\text { D-food pa } \\
\text { Pac_nF_B }\end{array}$ & $\begin{array}{l}\text { k. } \\
\text { Pac_nF_OR }\end{array}$ & $\begin{array}{r}\text { A } \\
\text { Agro_2D }\end{array}$ & $\begin{array}{l}\text { ggricultt } \\
\text { Agro_P }\end{array}$ & Agro_of & $\begin{array}{r}\text { Aut } \\
\text { Auto_2 }\end{array}$ & $\begin{array}{l}\text { motive } \\
\text { Auto_OR }\end{array}$ & BC_2D & $\begin{array}{l}B \& C \\
B C . P\end{array}$ & BC_OR & $\begin{array}{r}\text { Elec } \\
\text { Electro_2 }\end{array}$ & $\begin{array}{l}\text { ronics } \\
\text { Electro_OR }\end{array}$ & $\begin{array}{l}\text { Fibers } \\
\text { Fibers }\end{array}$ & Other & $\begin{array}{l}\text { Others } \\
\text { Other_Fu }\end{array}$ & Other_OR & SUM \\
\hline Recycled & Trade & & & & & & & & & & & & & & & & & & & & & 0 \\
\hline Virgin & Trade & 4497128 & 397936 & 161611 & 2407793 & 1760749 & 118994 & 365360 & 77688 & 60790 & 0 & 517785 & 548048 & 81201236 & 0 & 0 & 421489 & 0 & 0 & 255741 & 1742712 & 14535062 \\
\hline Import & Trade & 0 & 0 & 0 & 0 & 0 & 0 & 0 & 0 & 0 & 0 & 0 & 6579 & 14421 & 0 & 0 & 197000 & 1035100 & 0 & 57378 & 390998 & 1701477 \\
\hline$\overline{\text { Trade }}$ & Use & 3797268 & 336008 & 136460 & 2033083 & 1486734 & 100476 & 340516 & 72405 & 56656 & 0 & 412484 & 516812 & 21132772 & 0 & 0 & \begin{tabular}{l|l}
593621 & 1
\end{tabular} & 1035100 & 0 & 295217 & 2011721 & 14357335 \\
\hline Trade & Exports & 335593 & 29696 & 12060 & 179679 & 131394 & 8880 & 0 & 0 & 0 & 0 & 75787 & 0 & 0 & 0 & 0 & 0 & 0 & 0 & 0 & 0 & 773088 \\
\hline Trade & Source-separation & 364267 & 32233 & 13090 & 195031 & 142621 & 9639 & 24844 & 5283 & 4134 & 0 & 29514 & 37815 & 82885 & 0 & 0 & 24868 & 0 & 0 & 17902 & 121990 & 1106116 \\
\hline Use & Source-separation & 3797267 & 336008 & 136460 & 2033083 & 1486734 & 100476 & 303062 & 65499 & 49178 & 0 & 177242 & 20233 & 45036 & 0 & 0 & 304765 & 840346 & 0 & 237430 & 1679990 & 11612809 \\
\hline Use & Stock & 1 & 0 & 0 & 1 & 0 & 0 & 37454 & 6906 & 7479 & 0 & 235242 & 496579 & 1087736 & 0 & 0 & 288856 & 194754 & 0 & 57787 & 331731 & 2744526 \\
\hline Source-separation & Separate collection & 2126469 & 149869 & 28873 & 1138526 & 663124 & 21259 & 181837 & 39299 & 29507 & 0 & 0 & 5564 & 10133 & 0 & 0 & 105144 & 420173 & 0 & 73841 & 522477 & 5516095 \\
\hline Source-separation & Residual collection & 1670797 & 186139 & 107587 & 894556 & 823610 & 79217 & 121225 & 26200 & 19671 & 0 & 177242 & 14669 & 34903 & 0 & 0 & 199621 & 420173 & 0 & 163589 & 1157513 & 6096714 \\
\hline Separate collection & Exports & 806511 & 56841 & 10951 & 431812 & 251504 & 8063 & 1569 & 339 & 255 & 0 & 0 & 0 & 0 & 0 & 0 & 9 & 0 & 0 & 637 & 4508 & 1572999 \\
\hline Separate collection & Plastic sorting & 1319958 & 93028 & 17922 & 706715 & 411619 & 13196 & 180268 & 38960 & 29252 & 0 & 0 & 5564 & 10133 & 0 & 0 & 105135 & 420173 & 0 & 73204 & 517969 & 3943096 \\
\hline$\overline{P l a s t i c ~ s o r t i n g ~}$ & Incineration & 332543 & 13430 & 10711 & 178046 & 59423 & 7886 & 60393 & 14526 & 13051 & 0 & 0 & 806 & 1307 & 0 & 0 & 46699 & 420173 & 0 & 22099 & 156368 & 1337461 \\
\hline Plastic sorting & Landfill & 218231 & 8813 & 7029 & 116842 & 38997 & 5175 & 39633 & 9532 & 8565 & 0 & 0 & 307 & 719 & 0 & 0 & 30646 & 0 & 0 & 14503 & 102616 & 601610 \\
\hline Prod_con_w & Prod_con_w & 364267 & 32233 & 13090 & 195031 & 142621 & 9639 & 24844 & 5283 & 4134 & 0 & 29514 & 37815 & 82885 & 0 & 0 & 24868 & 0 & 0 & 17902 & 121990 & 1106116 \\
\hline Plastic sorting & Recycling & 769184 & 70784 & 183 & 411827 & 313199 & 134 & 80242 & 14902 & 7636 & 0 & 0 & 4451 & 8106 & 0 & 0 & 27789 & 0 & 0 & 36602 & 258984 & 2004025 \\
\hline Residual collection & Incineration & 1002478 & 111684 & 64552 & 536734 & 494166 & 47530 & 72735 & 15720 & 11803 & 0 & 159518 & 10623 & 22518 & 0 & 0 & 119773 & 420173 & 0 & 98154 & 694508 & 3882668 \\
\hline Residual collection & Landfill & 668319 & 74456 & 43035 & 357823 & 329444 & 31687 & 48490 & 10480 & 7868 & 0 & 17724 & 4047 & 12385 & 0 & 0 & 79849 & 0 & 0 & 65436 & 463005 & 2214046 \\
\hline Residual collection & Recycling & 0 & 0 & 0 & 0 & 0 & 0 & 0 & 0 & 0 & 0 & 0 & 0 & 0 & 0 & 0 & 0 & 0 & 0 & 0 & 0 & 0 \\
\hline Recycling & Recycled raw material & 0 & 0 & 0 & 431439 & 177784 & 0 & 9228 & 3428 & 1756 & 0 & 0 & 1692 & 3080 & 0 & 0 & 24455 & 0 & 0 & 150062 & 454959 & 1257883 \\
\hline Recycling & Landfill & 86860 & 2075 & 14 & 46505 & 9183 & 11 & 24481 & 4547 & 2330 & 0 & 0 & 295 & 690 & 0 & 0 & 1321 & 0 & 0 & 14503 & 102616 & 295432 \\
\hline Prod_con_w & Prod_con_w & 364267 & 32233 & 13090 & 195031 & 142621 & 9639 & 24844 & 5283 & 4134 & 0 & 29514 & 37815 & 82885 & 0 & 0 & 24868 & 0 & 0 & 17902 & 121990 & 1106116 \\
\hline
\end{tabular}

Table S5.10 Detailed PE flow values [ton] in year 50 in S1a: Constant demand. Prod_con_w: Pre-consumer waste. Flow abbreviations are provided in Table S1.1 and on page 53.

\begin{tabular}{|c|c|c|c|c|c|c|c|c|c|c|c|c|c|c|c|c|c|c|c|c|c|c|}
\hline \multirow[b]{2}{*}{ From } & \multirow[b]{2}{*}{ To } & \multicolumn{3}{|c|}{ Food pack. } & \multicolumn{3}{|c|}{ Non-food pack. } & \multicolumn{3}{|c|}{ Agriculture } & \multirow{2}{*}{\multicolumn{2}{|c|}{$\begin{array}{c}\text { Automotive } \\
\text { Auto 2D Auto_OR }\end{array}$}} & \multicolumn{3}{|c|}{$B \& C$} & \multirow{2}{*}{\multicolumn{2}{|c|}{$\begin{array}{l}\text { Electronics } \\
\text { ro 2D Electro_ OR }\end{array}$}} & \multirow{2}{*}{$\begin{array}{l}\text { Fibers } \\
\text { Fibers }\end{array}$} & \multirow{2}{*}{\multicolumn{3}{|c|}{$\begin{array}{c}\text { Others } \\
\text { Other_2D Other_Fu } \\
\end{array}$}} & \multirow{2}{*}{ SUM } \\
\hline & & Pac_F_2D & Pac_F_B & Pac_F_OR & Pac_nF_2D & Pac_nF_B & Pac_nF_OF & Agro_2D & Agro_p & Agro_OR & & & BC_2D & BC_P & BC_OR & & & & & & & \\
\hline Recycled & Trade & 364267 & 32233 & 13090 & 627611 & 320405 & 9639 & 35213 & 9072 & 6157 & 0 & 29514 & 80927 & 160235 & 0 & 0 & 72500 & 0 & 0 & 167964 & 692639 & 2621466 \\
\hline Virgin & Trade & 4132861 & 365703 & 148520 & 1780182 & 1440344 & 109356 & 330147 & 68616 & 54633 & 0 & 488271 & 467121 & 1041002 & 0 & 0 & 348989 & 0 & 0 & 87776 & 1050074 & 11913596 \\
\hline Import & Trade & 0 & 0 & 0 & 0 & 0 & 0 & 0 & 0 & 0 & 0 & 0 & 6579 & 14421 & 0 & 0 & 197000 & 1035100 & 0 & 57378 & 390998 & 1701477 \\
\hline Trade & Exports & 335593 & 29696 & 12060 & 79679 & 131394 & 8880 & 0 & 0 & 0 & 0 & 75787 & 0 & 0 & 0 & 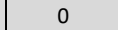 & 0 & 0 & 0 & 0 & 0 & 773088 \\
\hline Trade & Source-separation & 364267 & 32233 & 13090 & 195031 & 142621 & 9639 & 24844 & 5283 & 4134 & 0 & 29514 & 37815 & 82885 & 0 & 0 & 24868 & 0 & 0 & 17902 & 121990 & 1106116 \\
\hline Use & Source-separation & 3797268 & 336008 & 136460 & 2033083 & 1486734 & 100476 & 340516 & 72405 & 56656 & 0 & 412484 & 516065 & 1131509 & 0 & 0 & 593621 & 1035100 & 0 & 295217 & 2011721 & 14355325 \\
\hline Use & Stock & 0 & 0 & 0 & 0 & 0 & 0 & 0 & 0 & 0 & 0 & 0 & 747 & 1263 & 0 & 0 & 0 & 0 & 0 & 0 & 0 & 2010 \\
\hline Source-separation & Separate collection & 2126470 & 149869 & 28873 & 1138527 & 663124 & 21259 & 204309 & 43443 & 33994 & 0 & 0 & 141918 & 254589 & 0 & 0 & 204799 & \begin{tabular}{|l|}
517550 \\
\end{tabular} & 0 & 91813 & 625645 & 6246182 \\
\hline Source-separation & Residual collection & 1670798 & 186139 & 107588 & 894557 & 823611 & 79217 & 136206 & 28962 & 22663 & 0 & 412484 & 374147 & 876919 & 0 & 0 & 388822 & 517550 & 0 & 203405 & 1386076 & 8109143 \\
\hline Separate collection & Exports & 806511 & 56841 & 10951 & 431812 & 251504 & 8063 & 1763 & 375 & 293 & 0 & 0 & 0 & 0 & 0 & 0 & 18 & 0 & 0 & 792 & 5398 & 1574322 \\
\hline Separate collection & Plastic sorting & 1319959 & 93028 & 17922 & 706715 & 411619 & 13196 & 202546 & 43068 & 33701 & 0 & 0 & 141918 & 254589 & 0 & 0 & 204781 & 517550 & 0 & 91020 & 620247 & 4671860 \\
\hline Plastic sorting & Incineration & 332543 & 13430 & 10711 & 178046 & 59423 & 7886 & 67857 & 16057 & 15036 & 0 & 0 & 20554 & 32850 & 0 & 0 & 90961 & \begin{tabular}{|l|}
517550 \\
\end{tabular} & 0 & 27478 & 187244 & 1577625 \\
\hline Plastic sorting & Landfill & 218231 & 8813 & 7029 & 116843 & 38997 & 5175 & 44531 & 10537 & 9867 & 0 & 0 & 7830 & 18068 & 0 & 0 & 59693 & 0 & 0 & 18032 & 122879 & 686526 \\
\hline Prod_con_w & Prod_con_w & 364267 & 32233 & 13090 & 195031 & 142621 & 9639 & 24844 & 5283 & 4134 & 0 & 29514 & 37815 & 82885 & 0 & 0 & 24868 & 0 & 0 & 17902 & 121990 & 1106116 \\
\hline Plastic sorting & Recycling & 769185 & 70784 & 183 & 411827 & 313199 & 134 & 90159 & 16474 & 8797 & 0 & 0 & 113534 & 203672 & 0 & 0 & 54128 & 0 & 0 & 45510 & 310123 & 2407709 \\
\hline Residual collection & Incineration & 1002479 & 111684 & 64553 & 536734 & 494166 & 47530 & 81724 & 17377 & 13598 & 0 & 371236 & 270934 & 565754 & 0 & 0 & 233293 & 517550 & 0 & 122043 & 831645 & 5282300 \\
\hline Residual collection & Landfill & 668319 & 74456 & 43035 & 357823 & 329444 & 31687 & 54482 & 11585 & 9065 & 0 & 41248 & 103213 & 311165 & 0 & 0 & 155529 & 0 & 0 & 81362 & 554430 & 2826843 \\
\hline Residual collection & Recycling & 0 & 0 & 0 & 0 & 0 & 0 & 0 & 0 & 0 & 0 & 0 & 0 & 0 & 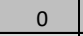 & 证 & 0 & 0 & 0 & 0 & 0 & 0 \\
\hline Recycling & Recycled raw material & 0 & 0 & 0 & 432580 & 177784 & 0 & 10368 & 3789 & 2023 & 0 & 0 & 43143 & 77395 & 0 & 0 & 47632 & 0 & 0 & 150062 & 570725 & 1515503 \\
\hline Recycling & Landfill & 86860 & 2075 & 14 & 46505 & 9183 & 11 & 27507 & 5026 & 2684 & 0 & 0 & 7517 & 17345 & 0 & 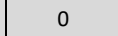 & 2574 & 0 & 0 & 18032 & 122879 & 348213 \\
\hline Prod_con_w & Prod_con_w & 364267 & 32233 & 13090 & 195031 & 142621 & 9639 & 24844 & 5283 & 4134 & 0 & 29514 & 37815 & 82885 & 0 & 0 & 24868 & 0 & 0 & 17902 & 121990 & 1106116 \\
\hline
\end{tabular}




\begin{tabular}{|c|c|c|c|c|c|c|c|c|c|c|c|c|c|c|c|c|c|c|c|c|c|c|}
\hline \multirow{2}{*}{$\begin{array}{l}\text { From } \\
\text { Recycled }\end{array}$} & To & \multicolumn{3}{|c|}{ Food pack. } & \multicolumn{3}{|c|}{ Non-food pack. } & \multicolumn{3}{|c|}{ Agriculture } & \multicolumn{2}{|c|}{ Automotive } & \multicolumn{3}{|c|}{$B \& C$} & \multicolumn{2}{|c|}{$\begin{array}{l}\text { Electronics } \\
\text { ro 2D Electr. }\end{array}$} & \multirow[t]{2}{*}{$\begin{array}{l}\text { Fibers } \\
\text { Fibers } \\
\end{array}$} & \multicolumn{3}{|c|}{$\begin{array}{l}\text { Others } \\
\text { Other 2D Other Fu }\end{array}$} & SUM \\
\hline & Trade & & & & & & & & & & & & & & & & & & & & & 0 \\
\hline Virgin & Trade & 791484 & 0 & 1243761 & 878460 & 921948 & 460974 & 0 & 0 & 607764 & 0 & 1298633 & 0 & 792627 & 0 & 0 & 482876 & 2000000 & 0 & 177481 & 1879215 & 11535224 \\
\hline Import & Trade & 0 & 0 & 0 & 0 & 0 & 0 & 0 & 0 & 0 & 0 & 0 & 0 & 9000 & 0 & 0 & 226000 & 1035100 & 0 & 39780 & 421200 & 1731080 \\
\hline Trade & Use & 495870 & 0 & 779224 & 550361 & 577607 & 288803 & 0 & 0 & 566436 & 0 & 1034611 & 0 & 755936 & 0 & 0 & 680387 & 2895100 & 0 & 244618 & 2168870 & 11037822 \\
\hline Trade & Exports & 231504 & 0 & 363792 & 256944 & 269664 & 134832 & 0 & 0 & 0 & 0 & 190000 & 0 & -9000 & 0 & 0 & 0 & 0 & 0 & -39780 & 0 & 1397956 \\
\hline Trade & Source-separation & 64110 & 0 & 100745 & 71155 & 74678 & 37339 & 0 & 0 & 41328 & 0 & 74022 & 0 & 54691 & 0 & 0 & 28490 & 140000 & 0 & 12424 & 131545 & 830527 \\
\hline Use & Source-separation & 495870 & 0 & 779224 & 550361 & 577606 & 288803 & 295315 & 63852 & 60775 & 0 & 593697 & 0 & 28755 & 0 & 0 & 304786 & 2350388 & 0 & 236279 & 1683565 & 8309276 \\
\hline Use & Stock & 0 & 0 & 0 & 0 & 0 & 0 & -295315 & -63852 & 505660 & 0 & 440914 & 0 & 727180 & 0 & 0 & 375601 & 544712 & 0 & 8339 & 485305 & 2728546 \\
\hline Source-separation & Separate collection & 344629 & 0 & 0 & 382501 & 258768 & 0 & 177189 & 38311 & 36465 & 0 & 0 & 0 & 20129 & 0 & 0 & 105151 & 1175194 & 0 & 73483 & 523589 & 3135408 \\
\hline Source-separation & Residual collection & 151240 & 0 & 779224 & 167860 & 318839 & 288803 & 118126 & 25541 & 24310 & 0 & 593697 & 0 & 8627 & 0 & 0 & 199635 & 1175194 & 0 & 162796 & 1159976 & 5173868 \\
\hline Separate collection & Exports & 56366 & 0 & 0 & 62561 & 42323 & 0 & 0 & 0 & 136 & 0 & 0 & 0 & 0 & 0 & 0 & 4 & 21548 & 0 & 273 & 1948 & 185160 \\
\hline Separate collection & Plastic sorting & 288263 & 0 & 0 & 319940 & 216444 & 0 & 177189 & 38311 & 36330 & 0 & 0 & 0 & 20129 & 0 & 0 & 105147 & 1153646 & 0 & 73209 & 521640 & 2950248 \\
\hline Plastic sorting & Incineration & 72623 & 0 & 0 & 80604 & 72869 & 0 & 59361 & 14284 & 16209 & 0 & 0 & 0 & 2629 & 0 & 0 & 55694 & 696541 & 0 & 19891 & 141729 & 1232434 \\
\hline Plastic sorting & Landfill & 47659 & 0 & 0 & 52896 & 47820 & 0 & 38956 & 9374 & 10637 & 0 & 0 & 0 & 1397 & 0 & 0 & 36549 & 457105 & 0 & 13053 & 93009 & 808456 \\
\hline Prod_con_w & Prod_con_w & 64110 & 0 & 100745 & 71155 & 74678 & 37339 & 0 & 0 & 41328 & 0 & 74022 & 0 & 54691 & 0 & 0 & 28490 & 140000 & 0 & 12424 & 131545 & 830527 \\
\hline Plastic sorting & Recycling & 167981 & 0 & 0 & 186440 & 95755 & 0 & 78872 & 14654 & 9483 & 0 & 0 & 0 & 16103 & 0 & 0 & 12904 & 0 & 0 & 40265 & 286902 & 909359 \\
\hline Residual collection & Incineration & 90744 & 0 & 467534 & 100716 & 191303 & 173282 & 70876 & 15324 & 14586 & 0 & 534328 & 0 & 5634 & 0 & 0 & 119781 & \begin{tabular}{|l|}
709551 \\
\end{tabular} & 0 & 97678 & 695986 & 3287322 \\
\hline Residual collection & Landfill & 60496 & 0 & 311690 & 67144 & 127536 & 115521 & 47250 & 10216 & 9724 & 0 & 59370 & 0 & 2993 & 0 & 0 & 79854 & 465643 & 0 & 65118 & 463990 & 1886545 \\
\hline Residual collection & Recycling & 0 & 0 & 0 & 0 & 0 & 0 & 0 & 0 & 0 & 0 & 0 & 0 & 0 & 0 & 0 & 0 & 0 & 0 & 0 & 0 & 0 \\
\hline Recycling & Recycled raw material & 0 & 0 & 0 & 6046 & 0 & 0 & 0 & 0 & 2181 & 0 & 0 & 0 & 5556 & 0 & 0 & 10710 & 0 & 0 & 82743 & 253785 & 361021 \\
\hline Recycling & Landfill & 18969 & 0 & 0 & 21054 & 7209 & 0 & 24064 & 4471 & 2893 & 0 & 0 & 0 & 1732 & 0 & 0 & 869 & 0 & 0 & 15954 & 113678 & 210893 \\
\hline Prod_con_w & Prod_con_w & 64110 & 0 & 100745 & 71155 & 74678 & 37339 & 0 & 0 & 41328 & 0 & 74022 & 0 & 54691 & 0 & 0 & 28490 & 140000 & 0 & 12424 & 131545 & 830527 \\
\hline
\end{tabular}

Table S5.12 Detailed PP flow values [ton] in year 50 in S1a: Constant demand. Prod_con_w: Pre-consumer waste. Flow abbreviations are provided in Table S1.1 and on page 53.

\begin{tabular}{|c|c|c|c|c|c|c|c|c|c|c|c|c|c|c|c|c|c|c|c|c|c|c|}
\hline \multirow{3}{*}{ From } & \multirow{2}{*}{ To } & \multicolumn{3}{|c|}{ Food pack. } & \multicolumn{3}{|c|}{ Non-food pack. } & \multicolumn{3}{|c|}{ Agriculture } & \multirow{2}{*}{\multicolumn{2}{|c|}{$\begin{array}{c}\text { Automotive } \\
\text { Auto } 2 \mathrm{D} \text { Auto } \mathrm{OR}\end{array}$}} & \multicolumn{3}{|c|}{$B \& C$} & \multirow{2}{*}{\multicolumn{2}{|c|}{\begin{tabular}{|c|} 
Electronics \\
Electro 2D Electro OR
\end{tabular}}} & \multirow{2}{*}{$\begin{array}{l}\text { Fibers } \\
\text { Fibers }\end{array}$} & \multirow{2}{*}{\multicolumn{3}{|c|}{$\begin{array}{c}\text { Others } \\
\text { Other_2D Other_Fu }\end{array}$}} & \multirow[t]{2}{*}{ sum } \\
\hline & & Pac_F_2D & Pac_F_B & Pac_F_OR & Pac_nF_2D & Pac_nF_B & Pac_nF_OR & Agro_2D & D Agro_ & P Agro_OR & & & BC_2D & BC_P & BC_OR & & & & & & & \\
\hline & Trade & 64110 & 0 & 100745 & 71155 & 74678 & 37339 & 0 & 0 & 61657 & 0 & 74022 & 0 & 200314 & 0 & 0 & 52398 & 140000 & 0 & 95167 & 525397 & 1496982 \\
\hline Virgin & Trade & 727374 & 0 & 1143016 & 807305 & 847271 & 423635 & 0 & 0 & 546107 & 0 & 1224611 & 0 & 592313 & 0 & 0 & 430478 & 1860000 & 0 & 82315 & 1353817 & 10038242 \\
\hline Import & Trade & 0 & 0 & 0 & 0 & 0 & 0 & 0 & 0 & 0 & 0 & 0 & 0 & 9000 & 0 & 0 & 226000 & 1035100 & 0 & 39780 & 421200 & 1731080 \\
\hline Trade & Use & 495870 & 0 & 779224 & 550361 & 577607 & 288803 & 0 & 0 & 566436 & 0 & 1034611 & 0 & 755936 & 0 & 0 & 680387 & 2895100 & 0 & 244618 & 2168870 & 11037822 \\
\hline Trade & Exports & 231504 & 0 & 363792 & 256944 & 269664 & 134832 & 0 & 0 & 0 & 0 & 190000 & 0 & -9000 & 0 & 0 & 0 & 0 & 0 & -39780 & 0 & 1397956 \\
\hline Trade & Source-separation & 64110 & 0 & 100745 & 71155 & 74678 & 37339 & 0 & 0 & 41328 & 0 & 74022 & 0 & 54691 & 0 & 0 & 28490 & 140000 & 0 & 12424 & 131545 & 830527 \\
\hline Use & Source-separation & 495870 & 0 & 779224 & 550361 & 577607 & 288803 & 0 & 0 & 566436 & 0 & 1034611 & 0 & 754419 & 0 & 0 & 680387 & 2895100 & 0 & 244618 & 2168870 & 11036305 \\
\hline Use & Stock & 0 & 0 & 0 & 0 & 0 & 0 & 0 & 0 & 0 & 0 & 0 & 0 & 1516 & 促 & 0 & 0 & 0 & 0 & 0 & 0 & 1516 \\
\hline Source-separation & Separate collection & 344630 & 0 & 0 & 382501 & 258768 & 0 & 0 & 0 & 339861 & 0 & 0 & 0 & 528094 & 0 & 0 & 234733 & 1447550 & 0 & 76076 & 674518 & 4286731 \\
\hline Source-separation & Prod_con_w & 64110 & 0 & 100745 & 71155 & 74678 & 37339 & 0 & 0 & 41328 & 0 & 74022 & 0 & 54691 & 0 & 0 & 28490 & 140000 & 0 & 12424 & 131545 & 830527 \\
\hline Source-separation & Residual collection & 151240 & 0 & 779224 & 167860 & 318839 & 288803 & 0 & 0 & 226574 & 0 & 1034611 & 0 & 226326 & 0 & 0 & 445653 & 1447550 & 0 & 168542 & 1494351 & 6749574 \\
\hline Separate collection & Exports & 56367 & 0 & 0 & 62561 & 42323 & 0 & 0 & 0 & 1265 & 0 & 0 & 0 & 0 & 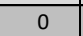 & 0 & 9 & 26542 & 0 & 283 & 2510 & 191859 \\
\hline Separate collection & Plastic sorting & 288263 & 0 & 0 & 319940 & 216445 & 0 & 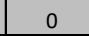 & 0 & 338597 & 0 & 0 & 0 & 528093 & 0 & 0 & 234724 & 1421008 & 0 & 75793 & 672009 & 4094872 \\
\hline Plastic sorting & Incineration & 72623 & 0 & 0 & 80604 & 72869 & 0 & 0 & 0 & 151071 & 0 & 0 & 0 & 68975 & 0 & 0 & 124329 & \begin{tabular}{|l|}
857967 \\
\end{tabular} & 0 & 20593 & 182583 & 1631614 \\
\hline Plastic sorting & Landfill & 47659 & 0 & 0 & 52896 & 47820 & 0 & 0 & 0 & 99140 & 0 & 0 & 0 & 36643 & 0 & 0 & 81591 & 563041 & 0 & 13514 & 119820 & 1062125 \\
\hline Prod_con_w & Prod_con_w & 64110 & 0 & 100745 & 71155 & 74678 & 37339 & 0 & 0 & 41328 & 0 & 74022 & 0 & 54691 & 0 & 0 & 28490 & 140000 & 0 & 12424 & 131545 & 830527 \\
\hline Plastic sorting & Recycling & 167981 & 0 & 0 & 186440 & 95755 & 0 & 0 & 0 & 88386 & 0 & 0 & 0 & 422475 & 0 & 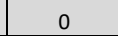 & 28805 & 0 & 0 & 41686 & 369605 & 1401133 \\
\hline Residual collection & Incineration & 90744 & 0 & 467534 & 100716 & 191303 & 173282 & 0 & 0 & 135945 & 0 & 931150 & 0 & 147805 & 0 & 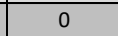 & 267392 & \begin{tabular}{|l|}
873992 \\
\end{tabular} & 0 & 101125 & 896611 & 4377600 \\
\hline Residual collection & Landfill & 60496 & 0 & 311690 & 67144 & 127536 & 115521 & 0 & 0 & 90630 & 0 & 103461 & 0 & 78521 & 0 & 0 & 178261 & 573558 & 0 & 67417 & 597741 & 2371975 \\
\hline Residual collection & Recycling & 0 & 0 & 0 & 0 & 0 & 0 & 0 & 0 & 0 & 0 & 0 & 0 & 0 & 0 & 0 & 0 & 0 & 0 & 0 & 0 & 0 \\
\hline Recycling & Recycled raw material & 0 & 0 & 0 & 0 & 0 & 0 & 0 & 0 & 20329 & 0 & 0 & 0 & 145754 & 0 & 0 & 23908 & 0 & 0 & 82743 & 393983 & 666717 \\
\hline Recycling & Incineration & 28905 & 0 & 0 & 32082 & 10985 & 0 & 0 & 0 & 41091 & 0 & 0 & 0 & 85530 & 0 & 0 & 2957 & 0 & 0 & 25169 & 223158 & 449876 \\
\hline Recycling & Landfill & 18969 & 0 & 0 & 21054 & 7209 & 0 & 0 & 0 & 26966 & 0 & 0 & 0 & 45438 & 0 & 0 & 1940 & 0 & 0 & 16517 & 146447 & 284540 \\
\hline Prod_con_w & Prod_con_w & 64110 & 0 & 100745 & 71155 & 74678 & 37339 & 0 & 0 & 41328 & 0 & 74022 & 0 & 54691 & 0 & 0 & 28490 & 140000 & 0 & 12424 & 131545 & 830527 \\
\hline
\end{tabular}


S5.3 No export of waste (S1b)

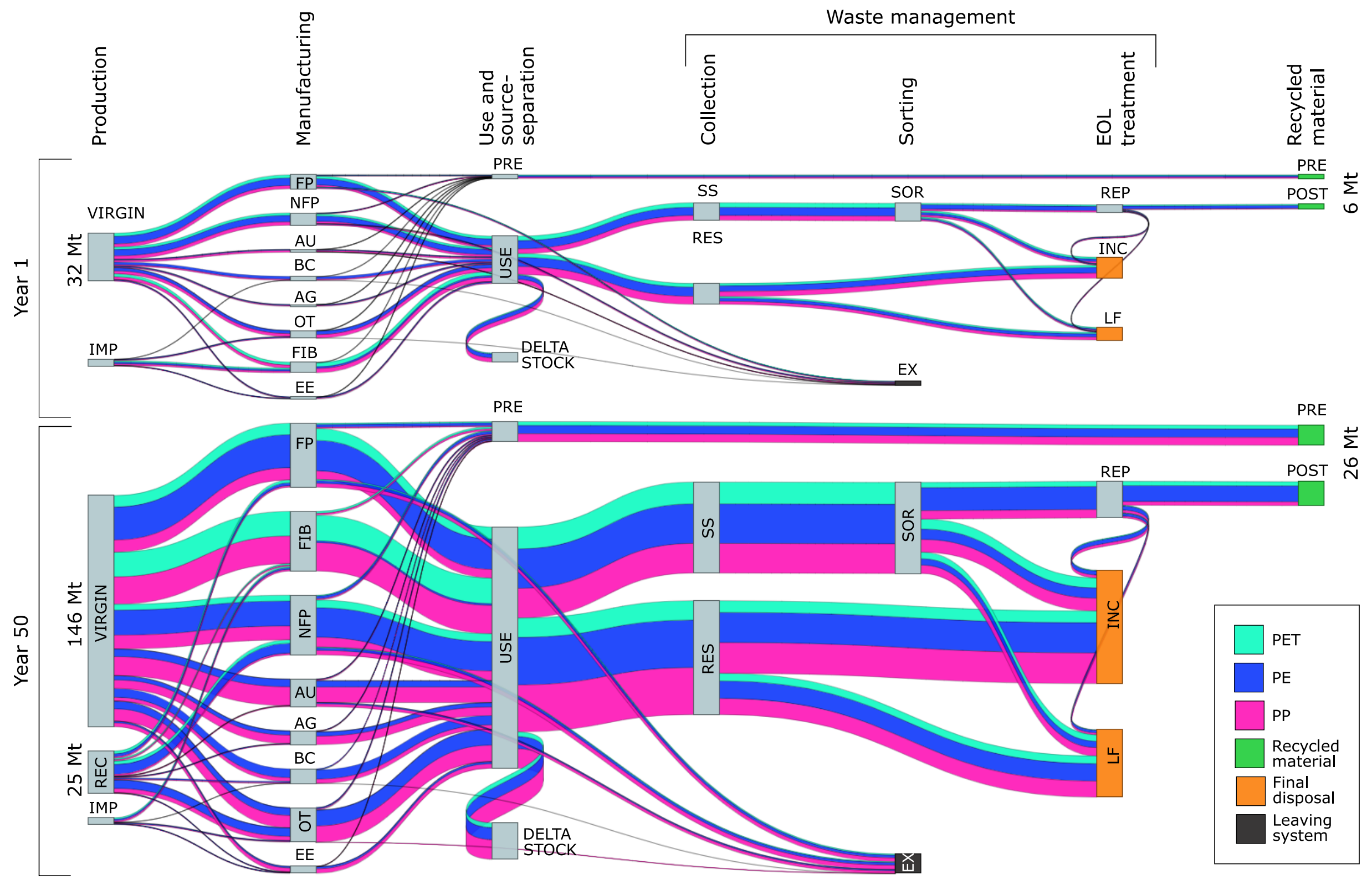

Figure S5.3 Sankey diagram for S1b: No export of waste in year 1 and year 50. AG: Agriculture, AU: Automotive, BC: Building and construction, EE: Electrical and electronics, EX: Exports, FIB: Fibers, FP: Food packaging, IMP: Import, INC: Incineration, LF: Landfill, NFP: Non-food packaging, PRE: Pre-consumer, OT: Others, POST: Post-consumer, REC: Recycled plastic, REP: Reprocessing, RES: Residual waste, SOR: Sorting, SS: Source-separated waste. 


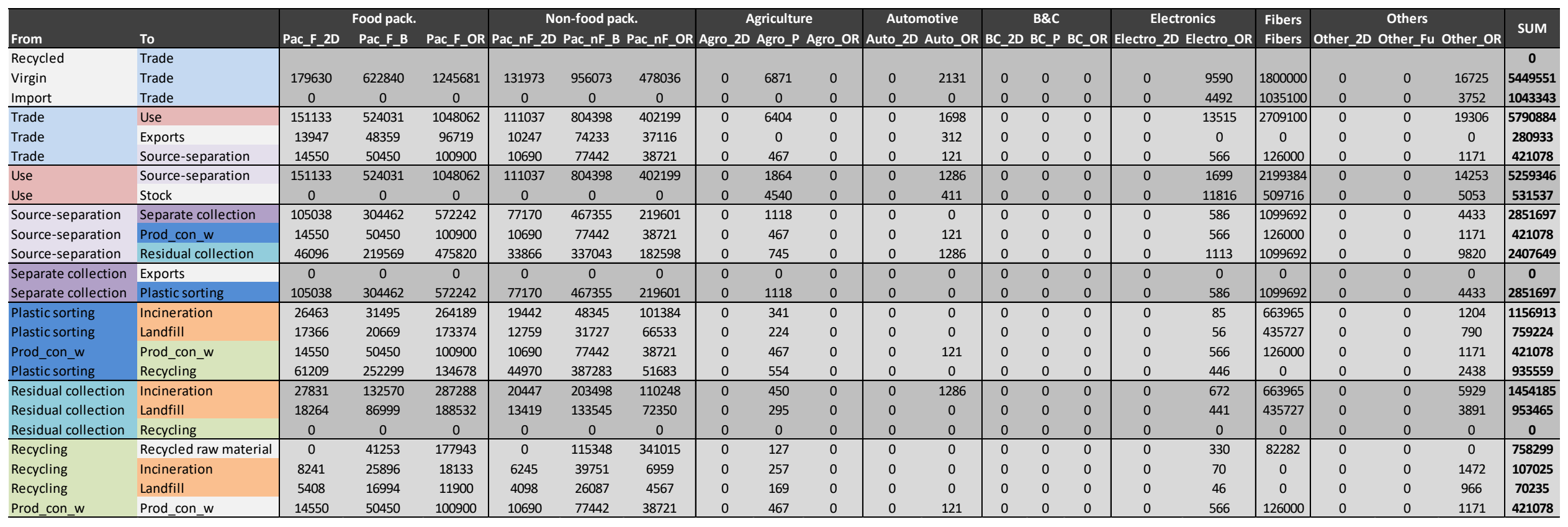

Table S5.14 Detailed PET flow values [ton] in year 50 in S1b: No export of waste. Prod_con_w: Pre-consumer waste. Flow abbreviations are provided in Table S1.1 and on page 53.

\begin{tabular}{|c|c|c|c|c|c|c|c|c|c|c|c|c|c|c|c|c|c|c|c|c|c|c|}
\hline \multirow[b]{2}{*}{ From } & \multirow[b]{2}{*}{ To } & \multicolumn{3}{|c|}{ Food pack. } & \multicolumn{3}{|c|}{ Non-food pack. } & \multicolumn{3}{|c|}{ Agriculture } & \multicolumn{2}{|c|}{ Automotive } & \multirow{2}{*}{ BC_2D } & \multicolumn{2}{|l|}{$B \& C$} & \multicolumn{2}{|c|}{ Electronics } & \multirow{2}{*}{\begin{tabular}{|l} 
Fibers \\
Fibers \\
\end{tabular}} & \multicolumn{3}{|c|}{ Others } & \multirow{2}{*}{ sum } \\
\hline & & Pac_F_2D & Pac_F_B & Pac_F_OR & Pac_nF_2D & Pac_nF_B & Pac_nF_OR & Agro_2t & D Agro_P & Agro_OR & R Auto_2L & Auto_OR & & BC_P & BC_OR & R Electro_2D & ) Electro_OR & & Other_2D & Other_Fu & u Other_OR & \\
\hline Recycled & Trade & 81633 & 408815 & 1317902 & 59975 & 786137 & 1381132 & 0 & 6302 & 0 & 0 & 681 & 0 & 0 & 0 & 0 & 11707 & 957768 & 0 & 0 & 6569 & 5018621 \\
\hline Virgin & Trade & 506025 & 1535537 & 5484700 & 371774 & 2198482 & 1229402 & 0 & 61970 & 0 & 0 & 20493 & 0 & 0 & 0 & 0 & 45741 & 16127196 & 0 & 0 & 82676 & 27663996 \\
\hline Import & Trade & 0 & 0 & 0 & 0 & 0 & 0 & 0 & 0 & 0 & 0 & 0 & 0 & 0 & 0 & 0 & 4492 & 1035100 & 0 & 0 & 3752 & 1043343 \\
\hline Trade & Use & 494431 & 1635893 & 5723416 & 363255 & 2511130 & 2196390 & 0 & 63630 & 0 & 0 & 16868 & 0 & 0 & 0 & 0 & 58549 & 16924117 & 0 & 0 & 86749 & 30074428 \\
\hline Trade & Exports & 45628 & 150966 & 528176 & 33522 & 231735 & 202690 & 0 & 0 & 0 & 0 & 3099 & 0 & 0 & 0 & 0 & 0 & 0 & 0 & 0 & 0 & 1195816 \\
\hline Trade & Source-separation & 47600 & 157492 & 551011 & 34972 & 241754 & 211453 & 0 & 4643 & 0 & 0 & 1207 & 0 & 0 & 0 & 0 & 3389 & 1195947 & 0 & 0 & 6247 & 2455716 \\
\hline Use & Source-separation & 494431 & 1635893 & 5723416 & 363255 & 2511130 & 2196390 & 0 & 56523 & 0 & 0 & 9373 & 0 & 0 & 0 & 0 & 45475 & 13934605 & 0 & 0 & 70231 & 27040722 \\
\hline Use & Stock & 0 & 0 & 0 & 0 & 0 & 0 & 0 & 7107 & 0 & 0 & 7495 & 0 & 0 & 0 & 0 & 13074 & 2989512 & 0 & 0 & 16519 & 3033706 \\
\hline Source-separation & Separate collection & 343629 & 950454 & 3124985 & 252462 & 1458966 & 1199229 & 0 & 33914 & 0 & 0 & 0 & 0 & 0 & 0 & 0 & 15689 & \begin{tabular}{|l|}
6967303 \\
\end{tabular} & 0 & 0 & 21842 & 14368473 \\
\hline Source-separation & Residual collection & 150801 & 685439 & 2598431 & 110793 & 1052163 & 997161 & 0 & 22609 & 0 & 0 & 9373 & 0 & 0 & 0 & 0 & 29786 & 6967303 & 0 & 0 & 48389 & 12672249 \\
\hline Separate collection & Exports & 0 & 0 & 0 & 0 & 0 & 0 & 0 & 0 & 0 & 0 & 0 & 0 & 0 & 0 & 0 & 0 & 0 & 0 & 0 & 0 & 0 \\
\hline Separate collection & Plastic sorting & 343629 & 950454 & 3124985 & 252462 & 1458966 & 1199229 & 0 & 33914 & 0 & 0 & 0 & 0 & 0 & 0 & 0 & 15689 & 6967303 & 0 & 0 & 21842 & 14368473 \\
\hline Plastic sorting & Incineration & 86572 & 98319 & 1442726 & 63604 & 150922 & 553653 & 0 & 10341 & 0 & 0 & 0 & 0 & 0 & 0 & 0 & 2273 & 4206673 & 0 & 0 & 5934 & 6621018 \\
\hline Plastic sorting & Landfill & 56813 & 64522 & 946789 & 41740 & 99043 & 363335 & 0 & 6786 & 0 & 0 & 0 & 0 & 0 & 0 & 0 & 1492 & 2760629 & 0 & 0 & 3894 & 4345043 \\
\hline Prod_con_w & Prod_con_w & 47600 & 157492 & 551011 & 34972 & 241754 & 211453 & 0 & 4643 & 0 & 0 & 1207 & 0 & 0 & 0 & 0 & 3389 & 1195947 & 0 & 0 & 6247 & 2455716 \\
\hline Plastic sorting & Recycling & 200244 & 787613 & 735471 & 147118 & 1209002 & 282241 & 0 & 16787 & 0 & 0 & 0 & 0 & 0 & 0 & 0 & 11924 & 0 & 0 & 0 & 12013 & 3402412 \\
\hline Residual collection & Incineration & 91050 & 413850 & 1568864 & 66894 & 635268 & 602060 & 0 & 13651 & 0 & 0 & 9373 & 0 & 0 & 0 & 0 & 17984 & 4206673 & 0 & 0 & 29216 & 7654883 \\
\hline Residual collection & Landfill & 59751 & 271589 & 1029567 & 43899 & 416895 & 395102 & 0 & 8958 & 0 & 0 & 0 & 0 & 0 & 0 & 0 & 11802 & 2760629 & 0 & 0 & 19173 & 5017366 \\
\hline Residual collection & Recycling & 0 & 0 & 0 & 0 & 0 & 0 & 0 & 0 & 0 & 0 & 0 & 0 & 0 & 0 & 0 & 0 & 0 & 0 & 0 & 0 & 0 \\
\hline Recycling & Landfill & 17693 & 53052 & 64985 & 13407 & 81437 & 24938 & 0 & 5122 & 0 & 0 & 0 & 0 & 0 & 0 & 0 & 1228 & 0 & 0 & 0 & 4760 & 266623 \\
\hline Prod_con_w & Prod_con_w & 84855 & 294223 & 588447 & 62343 & 451639 & 225819 & 0 & 2725 & 0 & 0 & 708 & 0 & 0 & 0 & 0 & 3300 & 734828 & 0 & 0 & 6828 & 2455716 \\
\hline
\end{tabular}




\begin{tabular}{|c|c|c|c|c|c|c|c|c|c|c|c|c|c|c|c|c|c|c|c|c|c|c|}
\hline \multirow[b]{2}{*}{ From } & \multirow[b]{2}{*}{ To } & \multicolumn{3}{|c|}{ Food pack. } & \multicolumn{3}{|c|}{ Non-food pack. } & \multirow{2}{*}{\multicolumn{3}{|c|}{$\begin{array}{c}\text { Agriculture } \\
\text { Agro_2D Agro_P Agro_of }\end{array}$}} & \multirow{2}{*}{\multicolumn{2}{|c|}{$\begin{array}{c}\text { Automotive } \\
\text { Auto_2D Auto_OR }\end{array}$}} & \multicolumn{3}{|c|}{$B \& C$} & \multicolumn{2}{|c|}{ Electronics } & \multirow{3}{*}{$\begin{array}{l}\text { Fibers } \\
\text { Fibers } \\
\end{array}$} & \multirow{2}{*}{\multicolumn{3}{|c|}{\begin{tabular}{|c|} 
Others \\
Other 2D Other Fu Other OR
\end{tabular}}} & \multirow{2}{*}{ SUM } \\
\hline & & Pac_F_2D & Pac_F_B & Pac_F_OR & Pac_nF_2D & Pac_nF_B & Pac_nF_OR & & & & & & BC_2D & BC_P & BC_OR & Electro_2 & Electro_OR & & & & & \\
\hline Recycled & Trade & & & & & & & & & & & & & & & & & & & & & 0 \\
\hline Virgin & Trade & 4497128 & 397936 & 161611 & 2407793 & 1760749 & 118994 & 365360 & 77688 & 60790 & 0 & 517785 & 548048 & 1201236 & 0 & 0 & 421489 & 0 & 0 & 255741 & 1742712 & 14535062 \\
\hline Import & Trade & 0 & 0 & 0 & 0 & 0 & 0 & 0 & 0 & 0 & 0 & 0 & 6579 & 14421 & 0 & 0 & 197000 & 1035100 & 0 & 57378 & 390998 & 1701477 \\
\hline Trade & Use & 3797268 & 336008 & 136460 & 2033083 & 1486734 & 100476 & 340516 & 72405 & 56656 & 0 & 412484 & 516812 & 1132772 & 0 & 0 & 593621 & 1035100 & 0 & 295217 & 2011721 & 14357335 \\
\hline Trade & Exports & 335593 & 29696 & 12060 & 179679 & 131394 & 8880 & 0 & 0 & 0 & 0 & 75787 & 0 & 0 & 0 & 0 & 0 & 0 & 0 & 0 & 0 & 773088 \\
\hline Trade & Source-separation & 364267 & 32233 & 13090 & 195031 & 142621 & 9639 & 24844 & 5283 & 4134 & 0 & 29514 & 37815 & 82885 & 0 & 0 & 24868 & 0 & 0 & 17902 & 121990 & 1106116 \\
\hline Use & Source-separation & 3797267 & 336008 & 136460 & 2033083 & 1486734 & 100476 & 303062 & 65499 & 49178 & 0 & 177242 & 20233 & 45036 & 0 & 0 & 304765 & 840346 & 0 & 237430 & 1679990 & 11612809 \\
\hline Use & Stock & 1 & 0 & 0 & 1 & 0 & 0 & 37454 & 6906 & 7479 & 0 & 235242 & 496579 & 1087736 & 0 & 0 & 288856 & 194754 & 0 & 57787 & 331731 & 2744526 \\
\hline Source-separation & Separate collection & 2126469 & 149869 & 28873 & 1138526 & 663124 & 21259 & 181837 & 39299 & 29507 & 0 & 0 & 5564 & 10133 & 0 & 0 & 105144 & 420173 & 0 & 73841 & 522477 & 5516095 \\
\hline Source-separation & Residual collection & 1670797 & 186139 & 107587 & 894556 & 823610 & 79217 & 121225 & 26200 & 19671 & 0 & 177242 & 14669 & 34903 & 0 & 0 & 199621 & 420173 & 0 & 163589 & 1157513 & 6096714 \\
\hline Separate collection & Exports & 0 & 0 & 0 & 0 & 0 & 0 & 0 & 0 & 0 & 0 & 0 & 0 & 0 & 0 & 0 & 0 & 0 & 0 & 0 & 0 & 0 \\
\hline Separate collection & Plastic sorting & 2126469 & 149869 & 28873 & 1138526 & 663124 & 21259 & 181837 & 39299 & 29507 & 0 & 0 & 5564 & 10133 & 0 & 0 & 105144 & 420173 & 0 & 73841 & 522477 & 5516095 \\
\hline Plastic sorting & Incineration & 535731 & 21636 & 17255 & 286834 & 95732 & 12705 & 60919 & 14652 & 13165 & 0 & 0 & 806 & 1307 & 0 & 0 & 46703 & 420173 & 0 & 22292 & 157729 & 1707637 \\
\hline Plastic sorting & Landfill & 351573 & 14198 & 11324 & 188235 & 62824 & 8338 & 39978 & 9615 & 8639 & 0 & 0 & 307 & 719 & 0 & 0 & 30649 & 0 & 0 & 14629 & 103510 & 844538 \\
\hline Prod_con_w & Prod_con_w & 364267 & 32233 & 13090 & 195031 & 142621 & 9639 & 24844 & 5283 & 4134 & 0 & 29514 & 37815 & 82885 & 0 & 0 & 24868 & 0 & 0 & 17902 & 121990 & 1106116 \\
\hline Plastic sorting & Recycling & 1239166 & 114034 & 294 & 663458 & 504568 & 217 & 80941 & 15032 & 7702 & 0 & 0 & 4451 & 8106 & 0 & 0 & 27792 & 0 & 0 & 36920 & 261238 & 2963920 \\
\hline Residual collection & Incineration & 1002478 & 111684 & 64552 & 536734 & 494166 & 47530 & 72735 & 15720 & 11803 & 0 & 159518 & 10623 & 22518 & 0 & 0 & 119773 & 420173 & 0 & 98154 & 694508 & 3882668 \\
\hline Residual collection & Landfill & 668319 & 74456 & 43035 & 357823 & 329444 & 31687 & 48490 & 10480 & 7868 & 0 & 17724 & 4047 & 12385 & 0 & 0 & 79849 & 0 & 0 & 65436 & 463005 & 2214046 \\
\hline Residual collection & Recycling & 0 & 0 & 0 & 0 & 0 & 0 & 0 & 0 & 0 & 0 & 0 & 0 & 0 & 0 & 0 & 0 & 0 & 0 & 0 & 0 & 0 \\
\hline Recycling & Recycled raw material & 0 & 0 & 0 & 689496 & 286413 & 0 & 9308 & 3457 & 1772 & 0 & 0 & 1692 & 3080 & 0 & 0 & 24457 & 0 & 0 & 241752 & 730029 & 1991456 \\
\hline Recycling & Landfill & 139932 & 3344 & 23 & 74921 & 14794 & 17 & 24695 & 4586 & 2350 & 0 & 0 & 295 & 690 & 0 & 0 & 1321 & 0 & 0 & 14629 & 103510 & 385107 \\
\hline Prod_con_w & Prod_con_w & 364267 & 32233 & 13090 & 195031 & 142621 & 9639 & 24844 & 5283 & 4134 & 0 & 29514 & 37815 & 82885 & 0 & 0 & 24868 & 0 & 0 & 17902 & 121990 & 1106116 \\
\hline
\end{tabular}

Table S5.16 Detailed PE flow values [ton] in year 50 in S1b: No export of waste. Prod_con_w: Pre-consumer waste. Flow abbreviations are provided in Table S1.1 and on page 53.

\begin{tabular}{|c|c|c|c|c|c|c|c|c|c|c|c|c|c|c|c|c|c|c|c|c|c|c|}
\hline \multirow[b]{2}{*}{ From } & \multirow[b]{2}{*}{ To } & \multicolumn{3}{|c|}{ Food pack. } & \multicolumn{3}{|c|}{ Non-food pack. } & \multicolumn{3}{|c|}{ Agriculture } & \multirow{2}{*}{\multicolumn{2}{|c|}{$\begin{array}{l}\text { Automotive } \\
\text { ato 2D Auto OR }\end{array}$}} & \multicolumn{3}{|c|}{$B \& C$} & \multicolumn{2}{|c|}{ Electronics } & \multirow{2}{*}{$\begin{array}{l}\text { Fibers } \\
\text { Fibers }\end{array}$} & \multirow{2}{*}{\multicolumn{3}{|c|}{$\begin{array}{c}\text { Others } \\
\text { Other_2D Other_Fu }\end{array}$}} & \multirow{2}{*}{ sum } \\
\hline & & Pac_F_2D & Pac_F_B & Pac_F_OR & Pac_nF_2D & Pac_nF_B & Pac_nF_or & Agro_2D & Agro_P & Agro_OR & & & BC_2D & BC_P & BC_OR & Electro_2D & Electro_OR & & & & & \\
\hline Recycled & Trade & 1769076 & 156540 & 63574 & 3991536 & 2502146 & 46810 & 175682 & 45764 & 30813 & 0 & 143334 & 245600 & 513665 & 0 & 0 & 211836 & 0 & 0 & 1287100 & 4366003 & 15549480 \\
\hline Virgin & Trade & 18627664 & 2458112 & 669411 & 6929018 & 9066904 & 492889 & 2013057 & 419636 & 333359 & 0 & 5001519 & 1817348 & 4007996 & 0 & 0 & 986089 & 0 & 0 & 77498 & 4932878 & 57833378 \\
\hline Import & Trade & 0 & 0 & 0 & 0 & 0 & 0 & 0 & 0 & 0 & 0 & 0 & 6579 & 14421 & 0 & 0 & 197000 & 1035100 & 0 & 57378 & 390998 & 1701477 \\
\hline Trade & Use & 17222521 & 2207750 & 618915 & 9221056 & 9768630 & 455709 & 2039905 & 433752 & 339408 & 0 & 4098556 & 1927184 & 4224087 & 0 & 0 & 1324247 & 1035100 & 0 & 1326455 & 9038957 & 65282233 \\
\hline Trade & Exports & 1522083 & 195115 & 54698 & 4934 & 863327 & 40274 & 0 & 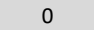 & 0 & 0 & 753041 & 0 & 0 & 0 & 0 & 0 & 0 & 0 & 0 & 0 & 4243473 \\
\hline Trade & Source-separation & 1652136 & 211787 & 59372 & 884565 & 937093 & 43716 & 148834 & 31647 & 24764 & 0 & 293257 & 142343 & 311995 & 0 & 0 & 70678 & 0 & 0 & 95522 & 650922 & 5558629 \\
\hline Use & Source-separation & 17222521 & 2207750 & 618915 & 9221056 & 9768630 & 455709 & 1859597 & 395413 & 309408 & 0 & 2277459 & 761526 & 1669520 & 0 & 0 & 1155422 & 1035100 & 0 & 1073876 & 7317794 & 57349694 \\
\hline Use & Stock & 0 & 0 & 0 & 0 & 0 & 0 & 180308 & 38340 & 30001 & 0 & 1821097 & 1165658 & 2554568 & 0 & 0 & 168825 & 0 & 0 & 252578 & 1721163 & 7932538 \\
\hline Source-separation & Separate collection & 9644612 & 984716 & 130952 & 5163791 & 4357073 & 96420 & 1115758 & 237248 & 185645 & 0 & 0 & 209420 & 375642 & 0 & 7 & 398621 & \begin{tabular}{|l|}
517550 \\
\end{tabular} & 0 & 333976 & 2275834 & 26027256 \\
\hline Source-separation & Residual collection & 7577909 & 1223034 & 487963 & 4057264 & 5411557 & 359289 & 743839 & 158165 & 123763 & 0 & 2277459 & 552106 & 1293878 & 0 & 0 & 756801 & 517550 & 0 & 739901 & 5041960 & 31322439 \\
\hline Separate collection & Exports & 0 & 0 & 0 & 0 & 0 & 0 & 0 & 0 & 0 & 0 & 0 & 0 & 0 & 0 & 0 & 0 & 0 & 0 & 0 & 0 & 0 \\
\hline Separate collection & Plastic sorting & 9644612 & 984716 & 130952 & 5163791 & 4357073 & 96420 & 1115758 & 237248 & 185645 & 0 & 0 & 209420 & 375642 & 0 & 0 & 398621 & 517550 & 0 & 333976 & 2275834 & 26027256 \\
\hline Plastic sorting & Incineration & 2429808 & 142158 & 78260 & 1300936 & 629008 & 57623 & 373798 & 88453 & 82829 & 0 & 0 & 30330 & 48470 & 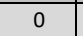 & 0 & 177061 & \begin{tabular}{|l|}
517550 \\
\end{tabular} & 0 & 100823 & 687044 & 6744151 \\
\hline Plastic sorting & Landfill & 1594562 & 93291 & 51358 & 853739 & 412787 & 37815 & 245305 & 58047 & 54356 & 0 & 0 & 11554 & 26658 & 0 & 0 & 116196 & 0 & 0 & 66165 & 450873 & 4072707 \\
\hline Prod_con_w & Prod_con_w & 1652136 & 211787 & 59372 & 884565 & 937093 & 43716 & 148834 & 31647 & 24764 & 0 & 293257 & 142343 & 311995 & 0 & 0 & 70678 & 0 & 0 & 95522 & 650922 & 5558629 \\
\hline Plastic sorting & Recycling & 5620241 & 749266 & 1334 & 3009116 & 3315279 & 982 & 496655 & 90747 & 48460 & 0 & 0 & 167536 & 300514 & O & 促 & 105363 & 0 & 0 & 166988 & 1137917 & 15210397 \\
\hline Residual collection & Incineration & 4546745 & 733820 & 292778 & 2434359 & 3246934 & 215573 & 446303 & 94899 & 74258 & 0 & 2049713 & 399801 & 834760 & 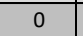 & 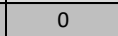 & 454081 & 517550 & 0 & 443940 & 3025176 & 19810691 \\
\hline Residual collection & Landfill & 3031164 & 489213 & 195185 & 1622906 & 2164623 & 143716 & 297535 & 63266 & 49505 & 0 & 227746 & 152305 & 459118 & 0 & 0 & 302721 & 0 & 0 & 295960 & 2016784 & 11511747 \\
\hline Residual collection & Recycling & 0 & 0 & 0 & 0 & 0 & 0 & 0 & 0 & 0 & 0 & 0 & 0 & 0 & 0 & 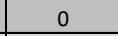 & 0 & 0 & 0 & 0 & 0 & 0 \\
\hline Recycling & Recycled raw material & 0 & 0 & 0 & 3142110 & 1881884 & 0 & 57115 & 20872 & 11146 & 0 & 0 & 63664 & 114195 & 0 & 0 & 92720 & 0 & 0 & 1242183 & 3904408 & 10530297 \\
\hline Recycling & Landfill & 634663 & 21969 & 106 & 339803 & 97206 & 78 & 151527 & 27686 & 14785 & 0 & 0 & 11092 & 25592 & 0 & 0 & 5010 & 0 & 0 & 66165 & 450873 & 1846554 \\
\hline Prod_con_w & Prod_con_w & 1830574 & 161982 & 65784 & 980102 & 716720 & 48437 & 124852 & 26548 & 20773 & 0 & 148317 & 190036 & 416528 & 0 & 0 & 124970 & 0 & 0 & 89963 & 613043 & 5558629 \\
\hline
\end{tabular}




\begin{tabular}{|c|c|c|c|c|c|c|c|c|c|c|c|c|c|c|c|c|c|c|c|c|c|c|}
\hline \multirow{2}{*}{$\begin{array}{l}\text { From } \\
\text { Recycled }\end{array}$} & To & \multicolumn{3}{|c|}{ Food pack. } & \multicolumn{3}{|c|}{ Non-food pack. } & \multicolumn{3}{|c|}{ Agriculture } & \multicolumn{2}{|c|}{ Automotive } & \multicolumn{3}{|c|}{$B \& C$} & \multicolumn{2}{|c|}{$\begin{array}{l}\text { Electronics } \\
\text { ro 2D Electr. }\end{array}$} & \multirow[t]{2}{*}{$\begin{array}{l}\text { Fibers } \\
\text { Fibers } \\
\end{array}$} & \multicolumn{3}{|c|}{$\begin{array}{l}\text { Others } \\
\text { Other 2D Other Fu }\end{array}$} & SUM \\
\hline & Trade & & & & & & & & & & & & & & & & & & & & & 0 \\
\hline Virgin & Trade & 791484 & 0 & 1243761 & 878460 & 921948 & 460974 & 0 & 0 & 607764 & 0 & 1298633 & 0 & 792627 & 0 & 0 & 482876 & 2000000 & 0 & 177481 & 1879215 & 11535224 \\
\hline Import & Trade & 0 & 0 & 0 & 0 & 0 & 0 & 0 & 0 & 0 & 0 & 0 & 0 & 9000 & 0 & 0 & 226000 & 1035100 & 0 & 39780 & 421200 & 1731080 \\
\hline Trade & Use & 495870 & 0 & 779224 & 550361 & 577607 & 288803 & 0 & 0 & 566436 & 0 & 1034611 & 0 & 755936 & 0 & 0 & 680387 & 2895100 & 0 & 244618 & 2168870 & 11037822 \\
\hline Trade & Exports & 231504 & 0 & 363792 & 256944 & 269664 & 134832 & 0 & 0 & 0 & 0 & 190000 & 0 & -9000 & 0 & 0 & 0 & 0 & 0 & -39780 & 0 & 1397956 \\
\hline Trade & Source-separation & 64110 & 0 & 100745 & 71155 & 74678 & 37339 & 0 & 0 & 41328 & 0 & 74022 & 0 & 54691 & 0 & 0 & 28490 & 140000 & 0 & 12424 & 131545 & 830527 \\
\hline Use & Source-separation & 495870 & 0 & 779224 & 550361 & 577606 & 288803 & 295315 & 63852 & 60775 & 0 & 593697 & 0 & 28755 & 0 & 0 & 304786 & 2350388 & 0 & 236279 & 1683565 & 8309276 \\
\hline Use & Stock & 0 & 0 & 0 & 0 & 0 & 0 & -295315 & -63852 & 505660 & 0 & 440914 & 0 & 727180 & 0 & 0 & 375601 & 544712 & 0 & 8339 & 485305 & 2728546 \\
\hline Source-separation & Separate collection & 344629 & 0 & 0 & 382501 & 258768 & 0 & \begin{tabular}{|l|}
177189 \\
\end{tabular} & 38311 & 36465 & 0 & 0 & 0 & 20129 & 0 & 0 & 105151 & 1175194 & 0 & 73483 & 523589 & 3135408 \\
\hline Source-separation & Residual collection & 151240 & 0 & 779224 & 167860 & 318839 & 288803 & 118126 & 25541 & 24310 & 0 & 593697 & 0 & 8627 & 0 & 0 & 199635 & 1175194 & 0 & 162796 & 1159976 & 5173868 \\
\hline Separate collection & Exports & 0 & 0 & 0 & 0 & 0 & 0 & 0 & 0 & 0 & 0 & 0 & 0 & 0 & 0 & 0 & 0 & 0 & 0 & 0 & 0 & 0 \\
\hline Separate collection & Plastic sorting & 344629 & 0 & 0 & 382501 & 258768 & 0 & 177189 & 38311 & 36465 & 0 & 0 & 0 & 20129 & 0 & 0 & 105151 & 1175194 & 0 & 73483 & 523589 & 3135408 \\
\hline Plastic sorting & Incineration & 86824 & 0 & 0 & 96365 & 87118 & 0 & 59361 & 14284 & 16270 & 0 & 0 & 0 & 2629 & 0 & 0 & 55696 & 709551 & 0 & 19965 & 142258 & 1290321 \\
\hline Plastic sorting & Landfill & 56978 & 0 & 0 & 63240 & 57171 & 0 & 38956 & 9374 & 10677 & 0 & 0 & 0 & 1397 & 0 & 0 & 36551 & 465643 & 0 & 13102 & 93357 & 846444 \\
\hline Prod_con_w & Prod_con_w & 64110 & 0 & 100745 & 71155 & 74678 & 37339 & 0 & 0 & 41328 & 0 & 74022 & 0 & 54691 & 0 & 0 & 28490 & 140000 & 0 & 12424 & 131545 & 830527 \\
\hline Plastic sorting & Recycling & 200827 & 0 & 0 & 222896 & 114479 & 0 & 78872 & 14654 & 9519 & 0 & 0 & 0 & 16103 & 0 & 0 & 12904 & 0 & 0 & 40416 & 287974 & 998643 \\
\hline Residual collection & Incineration & 90744 & 0 & 467534 & 100716 & 191303 & 173282 & 70876 & 15324 & 14586 & 0 & 534328 & 0 & 5634 & 0 & 0 & 119781 & \begin{tabular}{|l|}
709551 \\
\end{tabular} & 0 & 97678 & 695986 & 3287322 \\
\hline Residual collection & Landfill & 60496 & 0 & 311690 & 67144 & 127536 & 115521 & 47250 & 10216 & 9724 & 0 & 59370 & 0 & 2993 & 0 & 0 & 79854 & 465643 & 0 & 65118 & 463990 & 1886545 \\
\hline Residual collection & Recycling & 0 & 0 & 0 & 0 & 0 & 0 & 0 & 0 & 0 & 0 & 0 & 0 & 0 & 0 & 0 & 0 & 0 & 0 & 0 & 0 & 0 \\
\hline Recycling & Recycled raw material & 0 & 0 & 0 & 6046 & 0 & 0 & 0 & 0 & 2189 & 0 & 0 & 0 & 5556 & 0 & 0 & 10710 & 0 & 0 & 98923 & 302323 & 425747 \\
\hline Recycling & Landfill & 22678 & 0 & 0 & 25170 & 8618 & 0 & 24064 & 4471 & 2904 & 0 & 0 & 0 & 1732 & 0 & 0 & 869 & 0 & 0 & 16014 & 114103 & 220623 \\
\hline Prod_con_w & Prod_con_w & 64110 & 0 & 100745 & 71155 & 74678 & 37339 & 0 & 0 & 41328 & 0 & 74022 & 0 & 54691 & 0 & 0 & 28490 & 140000 & 0 & 12424 & 131545 & 830527 \\
\hline
\end{tabular}

Table S5.18 Detailed PP flow values [ton] in year 50 in S1b: No export of waste. Prod_con_w: Pre-consumer waste. Flow abbreviations are provided in Table S1.1 and on page 53.

\begin{tabular}{|c|c|c|c|c|c|c|c|c|c|c|c|c|c|c|c|c|c|c|c|c|c|c|}
\hline \multirow{2}{*}{ From } & \multirow[b]{2}{*}{ To } & \multicolumn{3}{|c|}{ Food pack. } & \multicolumn{3}{|c|}{ Non-food pack. } & \multicolumn{3}{|c|}{ Agriculture } & \multirow{2}{*}{\multicolumn{2}{|c|}{$\begin{array}{c}\text { Automotive } \\
\text { Auto_2D Auto_OR }\end{array}$}} & \multicolumn{3}{|c|}{$B \& C$} & \multicolumn{2}{|c|}{ Electronics } & \multirow{2}{*}{$\begin{array}{l}\text { Fibers } \\
\text { Fibers }\end{array}$} & \multirow{2}{*}{\multicolumn{3}{|c|}{$\begin{array}{c}\text { Others } \\
\text { Other 2D Other Fu }\end{array}$}} & \multirow{2}{*}{ sum } \\
\hline & & Pac_F_2D & Pac_F_B & Pac_F_OR & Pac_nF_2 2 & D Pac_nF_B & Pac_nF_OP & Agro_2 2 & D Agro & P Agro_OR & & & BC_2D & BC_P & BC_OR & Electro_2D & Electro_OR & & & & & \\
\hline Recycled & Trade & 383617 & 0 & 602826 & 425772 & 446850 & 223425 & 0 & 0 & 418983 & 0 & 442926 & 0 & 536605 & 0 & 0 & 248282 & 837719 & 0 & 509092 & 2300731 & 7376827 \\
\hline Virgin & Trade & 3206162 & 0 & 4781765 & 3558487 & 3734650 & 1772263 & 0 & 0 & 5619921 & 0 & 12460648 & 0 & 2446979 & 0 & 0 & 2644455 & 18145575 & 0 & 437925 & 7726508 & 66535339 \\
\hline Import & Trade & 0 & 0 & 0 & 0 & 0 & 0 & 0 & 0 & 0 & 0 & 0 & 0 & 9000 & 0 & 0 & 226000 & $\mid 1035100$ & 0 & 39780 & 421200 & 1731080 \\
\hline Trade & Exports & 1049987 & 0 & 1574958 & 1165370 & 1223062 & 583726 & 0 & 0 & 0 & 0 & 1887892 & 0 & -33878 & 0 & 0 & 0 & 0 & 0 & -212261 & 0 & 7238857 \\
\hline Trade & Source-separation & 290772 & 0 & 436152 & 322725 & 338702 & 161651 & 0 & 0 & 410645 & 0 & 735504 & 0 & 205867 & 0 & 0 & 170672 & 1328831 & 0 & 66291 & 701907 & 5169718 \\
\hline Use & Source-separation & 2249019 & 0 & 3373481 & 2496164 & 2619737 & 1250311 & 0 & 0 & 4999660 & 0 & 5712424 & 0 & 1113751 & 0 & 0 & 2289721 & 15367883 & 0 & 915235 & 7890554 & 50277942 \\
\hline Use & Stock & 0 & 0 & 0 & 0 & 0 & 0 & 0 & 0 & 628598 & 0 & 4567755 & 0 & 1706843 & 0 & 0 & 658344 & \begin{tabular}{|l|}
3321680 \\
\end{tabular} & 0 & 217532 & 1855978 & 12956731 \\
\hline Source-separation & Separate collection & 1563068 & 0 & 0 & 1734834 & 1173642 & 0 & 0 & 0 & 2999796 & 0 & 0 & 0 & 779626 & 0 & 0 & 789954 & \begin{tabular}{|l|}
7683942 \\
\end{tabular} & 0 & 284638 & 2453962 & 19463463 \\
\hline Source-separation & Residual collection & 685951 & 0 & 3373481 & 761330 & 1446095 & 1250311 & 0 & 0 & 1999864 & 0 & 5712424 & 0 & 334125 & 0 & 0 & 1499767 & 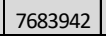 & 0 & 630597 & 5436592 & 30814479 \\
\hline Separate collection & Exports & 0 & 0 & 0 & 0 & 0 & 0 & 0 & 0 & 0 & 0 & 0 & 0 & 0 & 0 & 0 & 0 & 0 & 0 & 0 & 0 & 0 \\
\hline Separate collection & Plastic sorting & 1563068 & 0 & 0 & 1734834 & 1173642 & 0 & 0 & 0 & 2999796 & 0 & 0 & 0 & 779626 & 0 & 0 & 789954 & 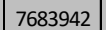 & 0 & 284638 & 2453962 & 19463463 \\
\hline Plastic sorting & Incineration & 393791 & 0 & 0 & 437064 & 395122 & 0 & 0 & 0 & 1338412 & 0 & 0 & 0 & 101829 & 0 & 0 & 418422 & \begin{tabular}{|l|}
4639361 \\
\end{tabular} & 0 & 77336 & 666737 & 8468073 \\
\hline Plastic sorting & Landfill & 258425 & 0 & 0 & 286823 & 259299 & 0 & 0 & 0 & 878333 & 0 & 0 & 0 & 54096 & 0 & 0 & 274589 & 3044581 & 0 & 50751 & 437546 & 5544444 \\
\hline Prod_con_w & Prod_con_w & 290772 & 0 & 436152 & 322725 & 338702 & 161651 & 0 & 0 & 410645 & 0 & 735504 & 0 & 205867 & 0 & 0 & 170672 & $\mid 1328831$ & 0 & 66291 & 701907 & 5169718 \\
\hline Plastic sorting & Recycling & 910853 & 0 & 0 & 1010946 & 519221 & 0 & 0 & 0 & 783051 & 0 & 0 & 0 & 623701 & 0 & 0 & 96943 & 0 & 0 & 156551 & 1349679 & 5450946 \\
\hline Residual collection & Incineration & 411571 & 0 & 2024089 & 456798 & 867657 & 750187 & 0 & 0 & 1199918 & 0 & 5141182 & 0 & 218204 & 0 & 0 & 899860 & \begin{tabular}{|l|}
4639361 \\
\end{tabular} & 0 & 378358 & 3261955 & 20249140 \\
\hline Residual collection & Landfill & 274380 & 0 & 1349392 & 304532 & 578438 & 500124 & 0 & 0 & 799946 & 0 & 571242 & 0 & 115921 & 0 & 0 & 599907 & $\mid 3044581$ & 0 & 252239 & 2174637 & 10565339 \\
\hline Residual collection & Recycling & 0 & 0 & 0 & 0 & 0 & 0 & 0 & 0 & 0 & O & 0 & 0 & 0 & 0 & 0 & 0 & 0 & 0 & 0 & 0 & 0 \\
\hline Recycling & Recycled raw material & 0 & 0 & 0 & 0 & 0 & 0 & 0 & 0 & 180102 & 0 & 0 & 0 & 215177 & 0 & 0 & 80463 & 0 & 0 & 448664 & 1561168 & 2485574 \\
\hline Recycling & Landfill & 102858 & 0 & 0 & 114161 & 39089 & 0 & 0 & 0 & 238904 & 0 & 0 & 0 & 67080 & 0 & 0 & 6530 & 0 & 0 & 62030 & 534779 & 1165429 \\
\hline Prod_con_w & Prod_con_w & 399062 & 0 & 627098 & 442915 & 464842 & 232421 & 0 & 0 & 257251 & 0 & 460760 & 0 & 340433 & 0 & 0 & 177338 & 871448 & 0 & 77333 & 818819 & 5169718 \\
\hline
\end{tabular}


S5.4 Mono-polymer design (S2a)

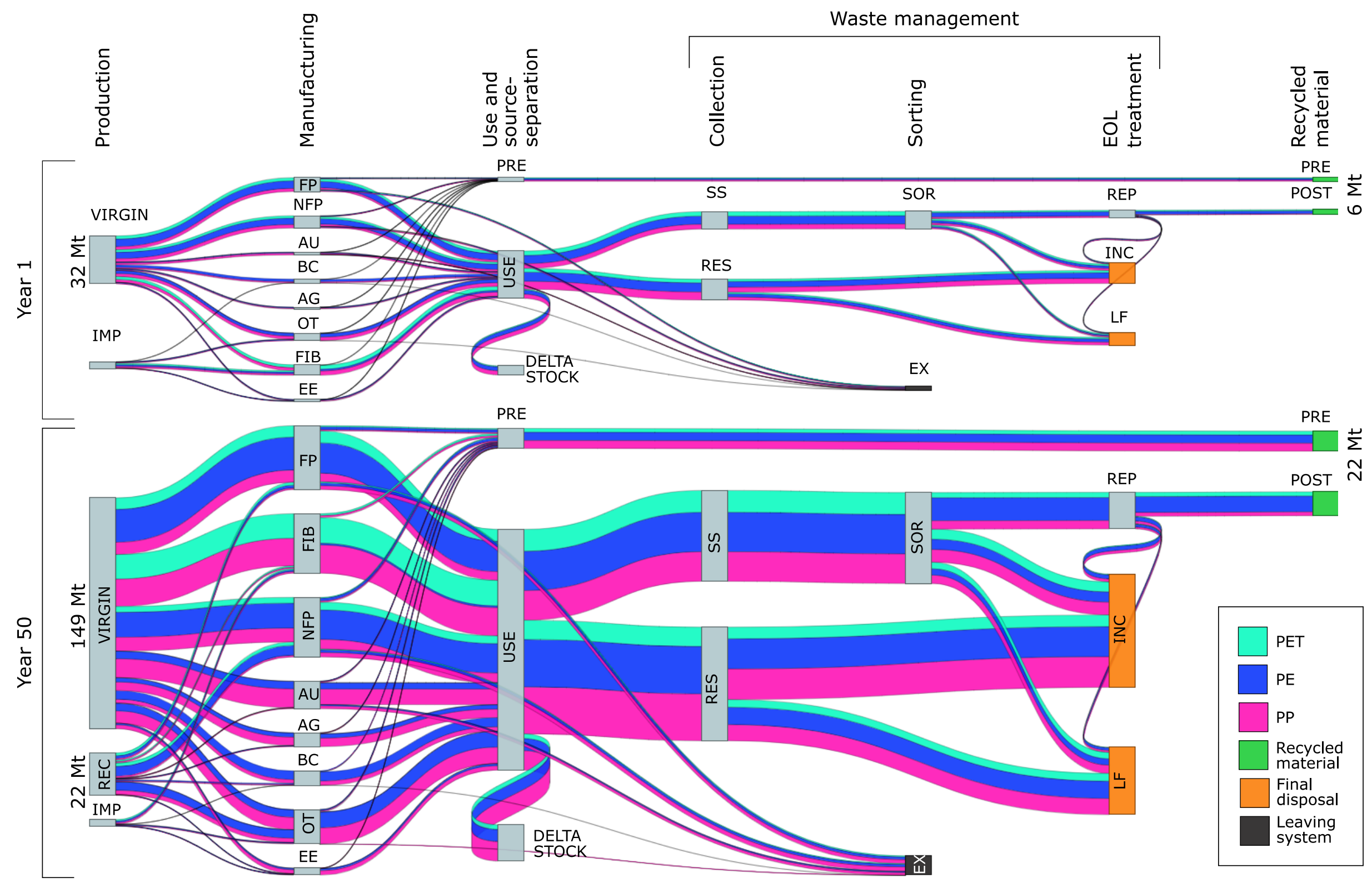

Figure S5.4 Sankey diagram for S2a: Mono-polymer design in year 1 and year 50. AG: Agriculture, AU: Automotive, BC: Building and construction, EE: Electrical and electronics, EX: Exports, FIB: Fibers, FP: Food packaging, IMP: Import, INC: Incineration, LF: Landfill, NFP: Non-food packaging, PRE: Pre-consumer, OT: Others, POST: Post-consumer, REC: Recycled plastic, REP: Reprocessing, RES: Residual waste, SOR: Sorting, SS: Source-separated waste. 


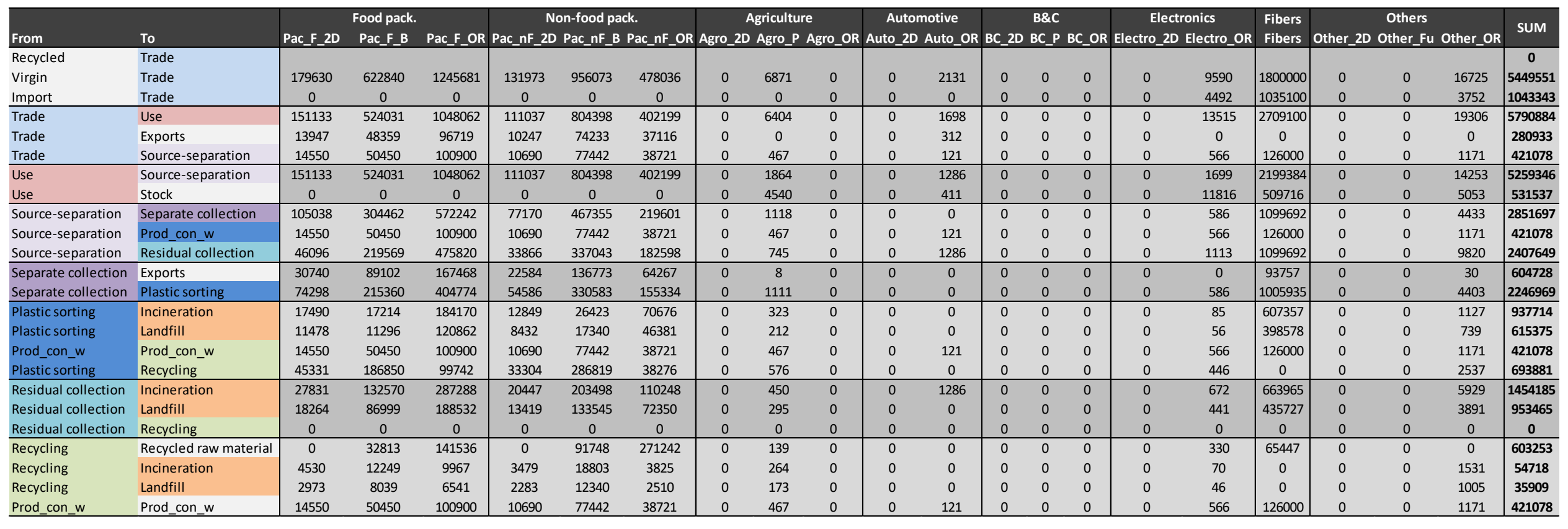

Table S5.20 Detailed PET flow values [ton] in year 50 in S2a: Mono-polymer design. Prod_con_w: Pre-consumer waste. Flow abbreviations are provided in Table S1.1 and on page 53.

\begin{tabular}{|c|c|c|c|c|c|c|c|c|c|c|c|c|c|c|c|c|c|c|c|c|c|c|}
\hline \multirow[b]{2}{*}{ From } & \multirow[b]{2}{*}{ To } & \multicolumn{3}{|c|}{ Food pack. } & \multicolumn{3}{|c|}{ Non-food pack. } & \multicolumn{3}{|c|}{ Agriculture } & \multicolumn{2}{|c|}{ Automotive } & \multirow{2}{*}{ BC_2D } & \multicolumn{2}{|l|}{ B\&C } & \multirow{2}{*}{\multicolumn{2}{|c|}{\begin{tabular}{|c|} 
Electronics \\
Electro_2D Electro_OR
\end{tabular}}} & \multirow{2}{*}{\begin{tabular}{|l|} 
Fibers \\
Fibers \\
\end{tabular}} & \multirow{2}{*}{\multicolumn{3}{|c|}{$\begin{array}{c}\text { Others } \\
\text { Other_2D Other_Fu Other OR }\end{array}$}} & \multirow{2}{*}{ SUM } \\
\hline & & Pac_F_2D & Pac_F_B & Pac_F_OR & Pac_nF_2 & D Pac_nF_B & Pac_nF_OR & Agro_2D & D Agro_P & Agro_of & Auto_21 & Auto_OR & & BC_P & C_OR & & & & & & & \\
\hline Recycled & Trade & 81633 & 383083 & 1164081 & 59975 & 714189 & 1142996 & 0 & 6633 & 0 & 0 & 681 & 0 & 0 & 0 & 0 & 11706 & \begin{tabular}{|l|}
906444 \\
\end{tabular} & 0 & 0 & 6569 & 4477991 \\
\hline Virgin & Trade & 506025 & 1561268 & 5638521 & 371774 & 2270431 & 1467538 & 0 & 61640 & 0 & 0 & 20493 & 0 & 0 & 0 & 0 & 45741 & 16178520 & 0 & 0 & 82676 & 28204626 \\
\hline Import & Trade & 0 & 0 & 0 & 0 & 0 & 0 & 0 & 0 & 0 & 0 & 0 & 0 & 0 & 0 & 0 & 4492 & 1035100 & 0 & 0 & 3752 & 1043343 \\
\hline Trade & Use & 494431 & 1635893 & 5723416 & 363255 & 2511130 & 2196390 & 0 & 63630 & 0 & 0 & 16868 & 0 & 0 & 0 & 0 & 58549 & 16924117 & 0 & 0 & 86749 & 30074428 \\
\hline Trade & Exports & 45628 & 150966 & 528176 & 33522 & 231735 & 202690 & 0 & 0 & 0 & 0 & 3099 & 0 & 0 & 0 & 0 & 0 & 0 & 0 & 0 & 0 & 1195816 \\
\hline Trade & Source-separation & 47600 & 157492 & 551011 & 34972 & 241754 & 211453 & 0 & 4643 & 0 & 0 & 1207 & 0 & 0 & 0 & 0 & 3389 & 1195947 & 0 & 0 & 6247 & 2455716 \\
\hline Use & Source-separation & 494431 & 1635893 & 5723416 & 363255 & 2511130 & 2196390 & 0 & 56523 & 0 & 0 & 9373 & 0 & 0 & 0 & 0 & 45475 & 13934605 & 0 & 0 & 70231 & 27040722 \\
\hline Use & Stock & 0 & 0 & 0 & 0 & 0 & 0 & 0 & 7107 & 0 & 0 & 7495 & 0 & 0 & 0 & 0 & 13074 & 2989512 & 0 & 0 & 16519 & 3033706 \\
\hline Source-separation & Prod_con_w & 47600 & 157492 & 551011 & 34972 & 241754 & 211453 & 0 & 4643 & 0 & 0 & 1207 & 0 & 0 & 0 & 0 & 3389 & $\mid 1195947$ & 0 & 0 & 6247 & 2455716 \\
\hline Source-separation & Residual collection & 150801 & 685439 & 2598431 & 110793 & 1052163 & 997161 & 0 & 22609 & 0 & 0 & 9373 & 0 & 0 & 0 & 0 & 29786 & 6967303 & 0 & 0 & 48389 & 12672249 \\
\hline Separate collection & Exports & 100564 & 278153 & 914536 & 73884 & 426971 & 350958 & 0 & 229 & 0 & 0 & 0 & 0 & 0 & 0 & 0 & 1 & 594016 & 0 & 0 & 147 & 2739458 \\
\hline Separate collection & Plastic sorting & 243065 & 672301 & 2210449 & 178578 & 1031996 & 848271 & 0 & 33685 & 0 & 0 & 0 & 0 & 0 & 0 & 0 & 15688 & 6373287 & 0 & 0 & 21694 & 11629015 \\
\hline Plastic sorting & Incineration & 57217 & 53736 & 1005745 & 42037 & 82486 & 385960 & 0 & 9793 & 0 & 0 & 0 & 0 & 0 & 0 & 0 & 2273 & \begin{tabular}{|l|}
3848022 \\
\end{tabular} & 0 & 0 & 5552 & 5492822 \\
\hline Plastic sorting & Landfill & 37549 & 35264 & 660020 & 27587 & 54132 & 253286 & 0 & 6426 & 0 & 0 & 0 & 0 & 0 & 0 & 0 & 1492 & 2525264 & 0 & 0 & 3644 & 3604664 \\
\hline Prod_con_w & Prod_con_w & 47600 & 157492 & 551011 & 34972 & 241754 & 211453 & 0 & 4643 & 0 & 0 & 1207 & 0 & 0 & 0 & 0 & 3389 & $\mid 1195947$ & 0 & 0 & 6247 & 2455716 \\
\hline Plastic sorting & Recycling & 148299 & 583300 & 544684 & 108955 & 895378 & 209025 & 0 & 17466 & 0 & 0 & 0 & 0 & 0 & 0 & 0 & 11923 & 0 & 0 & 0 & 12499 & 2531529 \\
\hline Residual collection & Incineration & 91050 & 413850 & 1568864 & 66894 & 635268 & 602060 & 0 & 13651 & 0 & 0 & 9373 & 0 & 0 & 0 & 0 & 17984 & 4206673 & 0 & 0 & 29216 & 7654883 \\
\hline Residual collection & Landfill & 59751 & 271589 & 1029567 & 43899 & 416895 & 395102 & 0 & 8958 & 0 & 0 & 0 & 0 & 0 & 0 & 0 & 11802 & 2760629 & 0 & 0 & 19173 & 5017366 \\
\hline Residual collection & Recycling & 0 & 0 & 0 & 0 & 0 & 0 & 0 & 0 & 0 & 0 & 0 & 0 & 0 & 0 & 0 & 0 & 0 & 0 & 0 & 0 & 0 \\
\hline Recycling & Incineration & 14819 & 38240 & 54428 & 11382 & 58699 & 20887 & 0 & 8005 & 0 & 0 & 0 & 0 & 0 & 0 & 0 & 1872 & 0 & 0 & 0 & 7546 & 215877 \\
\hline Recycling & Landfill & 9725 & 25095 & 35718 & 7469 & 38521 & 13707 & 0 & 5253 & 0 & 0 & 0 & 0 & 0 & 0 & 0 & 1228 & 0 & 0 & 0 & 4952 & 141670 \\
\hline Prod_con_w & Prod_con_w & 84855 & 294223 & 588447 & 62343 & 451639 & 225819 & 0 & 2725 & 0 & 0 & 708 & 0 & 0 & 0 & 0 & 3300 & \begin{tabular}{|l|}
734828 \\
\end{tabular} & 0 & 0 & 6828 & 2455716 \\
\hline
\end{tabular}




\begin{tabular}{|c|c|c|c|c|c|c|c|c|c|c|c|c|c|c|c|c|c|c|c|c|c|c|}
\hline From & To & Pac_F_2D & $\begin{array}{l}\text { Food pack. } \\
\text { Pac_F_B }\end{array}$ & Pac_F_OR & $\begin{array}{r}N \\
\text { Pac_nF_2D }\end{array}$ & $\begin{array}{l}\text { on-food pa } \\
\text { Pac_nF_B }\end{array}$ & Pac_nF_OR & $\begin{array}{r}\text { A } \\
\text { Agro_2D } \\
\end{array}$ & $\begin{array}{l}\text { ggricultt } \\
\text { Agro_P }\end{array}$ & Agro_or & $\begin{array}{r}\text { Aut } \\
\text { Auto_2 }\end{array}$ & $\begin{array}{l}\text { motive } \\
\text { Auto_OR }\end{array}$ & BC_2D & $\begin{array}{l}\text { B\&C } \\
\text { BC_P }\end{array}$ & BC_OR & $\begin{array}{r}\text { Elec } \\
\text { Electro_2 }\end{array}$ & $\begin{array}{l}\text { ronics } \\
\text { Electro_OR }\end{array}$ & $\begin{array}{l}\text { Fibers } \\
\text { Fibers } \\
\end{array}$ & Other_z & $\begin{array}{l}\text { Others } \\
\text { Other_Fu }\end{array}$ & Other_OR & SUM \\
\hline Recycled & Trade & & & & & & & & & & & & & & & & & & & & & 0 \\
\hline Virgin & Trade & 4497128 & 397936 & 161611 & 2407793 & 1760749 & 118994 & 365360 & 77688 & 60790 & 0 & 517785 & 548048 & 1201236 & 0 & 0 & 421489 & 0 & 0 & 255741 & 1742712 & 14535062 \\
\hline Import & Trade & 0 & 0 & 0 & 0 & 0 & 0 & 0 & 0 & 0 & 0 & 0 & 6579 & 14421 & 0 & 0 & 197000 & 1035100 & 0 & 57378 & 390998 & 1701477 \\
\hline Trade & Use & 3797268 & 336008 & 136460 & 2033083 & 1486734 & 100476 & 340516 & 72405 & 56656 & 0 & 412484 & 516812 & 1132772 & 0 & 0 & \begin{tabular}{l|l}
593621 & 1
\end{tabular} & 1035100 & 0 & 295217 & 2011721 & 14357335 \\
\hline Trade & Exports & 335593 & 29696 & 12060 & 179679 & 131394 & 8880 & 0 & 0 & 0 & 0 & 75787 & 0 & 0 & 0 & 0 & 0 & 0 & 0 & 0 & 0 & 773088 \\
\hline Trade & Source-separation & 364267 & 32233 & 13090 & 195031 & 142621 & 9639 & 24844 & 5283 & 4134 & 0 & 29514 & 37815 & 82885 & 0 & 0 & 24868 & 0 & 0 & 17902 & 121990 & 1106116 \\
\hline Use & Source-separation & \begin{tabular}{|l|}
3797267 \\
\end{tabular} & 336008 & 136460 & 2033083 & 1486734 & 100476 & 303062 & 65499 & 49178 & 0 & 177242 & 20233 & 45036 & 0 & 0 & 304765 & 840346 & 0 & 237430 & 1679990 & 11612809 \\
\hline Use & Stock & 1 & 0 & 0 & 1 & 0 & 0 & 37454 & 6906 & 7479 & 0 & 235242 & 496579 & 1087736 & 0 & 0 & 288856 & 194754 & 0 & 57787 & 331731 & 2744526 \\
\hline Source-separation & Separate collection & 2126469 & 149869 & 28873 & 1138526 & 663124 & 21259 & 181837 & 39299 & 29507 & 0 & 0 & 5564 & 10133 & 0 & 0 & 105144 & 420173 & 0 & 73841 & 522477 & 5516095 \\
\hline Source-separation & Residual collection & 1670797 & 186139 & 107587 & 894556 & 823610 & 79217 & 121225 & 26200 & 19671 & 0 & 177242 & 14669 & 34903 & 0 & 0 & 199621 & 420173 & 0 & 163589 & 1157513 & 6096714 \\
\hline Separate collection & Exports & 806511 & 56841 & 10951 & 431812 & 251504 & 8063 & 1569 & 339 & 255 & 0 & 0 & 0 & 0 & 0 & 0 & 9 & 0 & 0 & 637 & 4508 & 1572999 \\
\hline Separate collection & Plastic sorting & 1319958 & 93028 & 17922 & 706715 & 411619 & 13196 & 180268 & 38960 & 29252 & 0 & 0 & 5564 & 10133 & 0 & 0 & 105135 & 420173 & 0 & 73204 & 517969 & 3943096 \\
\hline Plastic sorting & Incineration & 326970 & 12917 & 10709 & 175062 & 57154 & 7885 & 58576 & 14188 & 12878 & 0 & 0 & 685 & 1111 & 0 & 0 & 46699 & 420173 & 0 & 21270 & 150504 & 1316783 \\
\hline Plastic sorting & Landfill & 214574 & 8477 & 7028 & 114884 & 37507 & 5175 & 38441 & 9311 & 8451 & 0 & 0 & 261 & 611 & 0 & 0 & 30646 & 0 & 0 & 13959 & 98768 & 588094 \\
\hline Prod_con_w & Prod_con_w & 364267 & 32233 & 13090 & 195031 & 142621 & 9639 & 24844 & 5283 & 4134 & 0 & 29514 & 37815 & 82885 & 0 & 0 & 24868 & 0 & 0 & 17902 & 121990 & 1106116 \\
\hline Plastic sorting & Recycling & 778415 & 71634 & 185 & 416769 & 316958 & 136 & 83251 & 15461 & 7922 & 0 & 0 & 4618 & 8410 & 0 & 0 & 27789 & 0 & 0 & 37974 & 268696 & 2038218 \\
\hline Residual collection & Incineration & 1002478 & 111684 & 64552 & 536734 & 494166 & 47530 & 72735 & 15720 & 11803 & 0 & 159518 & 10623 & 22518 & 0 & 0 & 119773 & 420173 & 0 & 98154 & 694508 & 3882668 \\
\hline Residual collection & Landfill & 668319 & 74456 & 43035 & 357823 & 329444 & 31687 & 48490 & 10480 & 7868 & 0 & 17724 & 4047 & 12385 & 0 & 0 & 79849 & 0 & 0 & 65436 & 463005 & 2214046 \\
\hline Residual collection & Recycling & 0 & 0 & 0 & 0 & 0 & 0 & 0 & 0 & 0 & 0 & 0 & 0 & 0 & 0 & 0 & 0 & 0 & 0 & 0 & 0 & 0 \\
\hline Recycling & Recycled raw material & 0 & 0 & 0 & 467120 & 192512 & 0 & 9933 & 3689 & 1890 & 0 & 0 & 1821 & 3316 & 0 & 0 & 24455 & 0 & 0 & 162494 & 492431 & 1359661 \\
\hline Recycling & Landfill & 72465 & 261 & 11 & 38798 & 1153 & 8 & 25115 & 4664 & 2390 & 0 & 0 & 288 & 674 & 0 & 0 & 1321 & 0 & 0 & 15046 & 106465 & 268658 \\
\hline Prod_con_w & Prod_con_w & 364267 & 32233 & 13090 & 195031 & 142621 & 9639 & 24844 & 5283 & 4134 & 0 & 29514 & 37815 & 82885 & 0 & 0 & 24868 & 0 & 0 & 17902 & 121990 & 1106116 \\
\hline
\end{tabular}

Table S5.22 Detailed PE flow values [ton] in year 50 in S2a: Mono-polymer design. Prod_con_w: Pre-consumer waste. Flow abbreviations are provided in Table S1.1 and on page 53.

\begin{tabular}{|c|c|c|c|c|c|c|c|c|c|c|c|c|c|c|c|c|c|c|c|c|c|c|}
\hline \multirow[b]{2}{*}{ From } & \multirow[b]{2}{*}{ To } & \multicolumn{3}{|c|}{ Food pack. } & \multicolumn{3}{|c|}{ Non-food pack. } & \multicolumn{3}{|c|}{ Agriculture } & \multirow{2}{*}{\multicolumn{2}{|c|}{$\begin{array}{l}\text { Automotive } \\
\text { ato 2D Auto OR }\end{array}$}} & \multicolumn{3}{|c|}{$B \& C$} & \multirow{2}{*}{\multicolumn{2}{|c|}{$\begin{array}{l}\text { Electronics } \\
\text { ro 2D Electro OR }\end{array}$}} & \multirow{2}{*}{$\begin{array}{l}\text { Fibers } \\
\text { Fibers }\end{array}$} & \multirow{2}{*}{\multicolumn{3}{|c|}{$\begin{array}{c}\text { Others } \\
\text { Other_2D Other_Fu }\end{array}$}} & \multirow{2}{*}{ sum } \\
\hline & & Pac_F_2D & Pac_F_B & Pac_F_OR & Pac_nF_2D & Pac_nF_B & Pac_nF_or & Agro_2D & Agro_P & Agro_OR & & & BC_2D & BC_P & BC_OR & & & & & & & \\
\hline Recycled & Trade & 1769076 & 156540 & 63574 & 3015172 & 1908898 & 46810 & 179376 & 47113 & 31534 & 0 & 143334 & 250333 & 522156 & 0 & 0 & 211828 & 0 & 0 & 893626 & 3192072 & 12431442 \\
\hline Virgin & Trade & 18627664 & 2458112 & 669411 & 7905383 & 9660153 & 492889 & 2009364 & 418286 & 332638 & 0 & 5001519 & 1812615 & 3999505 & 0 & 0 & 986097 & 0 & 0 & 470972 & 6106808 & 60951415 \\
\hline Import & Trade & 0 & 0 & 0 & 0 & 0 & 0 & 0 & 0 & 0 & 0 & 0 & 6579 & 14421 & 0 & 0 & 197000 & 1035100 & 0 & 57378 & 390998 & 1701477 \\
\hline Trade & Use & 17222521 & 2207750 & 618915 & 9221056 & 9768630 & 455709 & 2039905 & 433752 & 339408 & 0 & 4098556 & 1927184 & 4224087 & 0 & 0 & 1324247 & 1035100 & 0 & 1326455 & 9038957 & 65282233 \\
\hline Trade & Exports & 1522083 & 195115 & 54698 & 14934 & 863327 & 40274 & 0 & 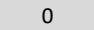 & 0 & 0 & 753041 & 0 & 0 & 0 & 0 & 0 & 0 & 0 & 0 & 0 & 4243473 \\
\hline Trade & Source-separation & 1652136 & 211787 & 59372 & 884565 & 937093 & 43716 & 148834 & 31647 & 24764 & 0 & 293257 & 142343 & 311995 & 0 & 0 & 70678 & 0 & 0 & 95522 & 650922 & 5558629 \\
\hline Use & Source-separation & 17222521 & 2207750 & 618915 & 9221056 & 9768630 & 455709 & 1859597 & 395413 & 309408 & 0 & 2277459 & 761526 & 1669520 & 0 & 0 & 1155422 & 1035100 & 0 & 1073876 & 7317794 & 57349694 \\
\hline Use & Stock & 0 & 0 & 0 & 0 & 0 & 0 & 180308 & 38340 & 30001 & 0 & 1821097 & 1165658 & 2554568 & 0 & 0 & 168825 & 0 & 0 & 252578 & 1721163 & 7932538 \\
\hline Source-separation & Separate collection & 9644612 & 984716 & 130952 & 5163791 & 4357073 & 96420 & 1115758 & 237248 & 185645 & 0 & 0 & 209420 & 375642 & 0 & 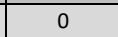 & 398621 & \begin{tabular}{|l|}
517550 \\
\end{tabular} & 0 & 333976 & 2275834 & 26027256 \\
\hline Source-separation & Residual collection & 7577909 & 1223034 & 487963 & 4057264 & 5411557 & 359289 & 743839 & 158165 & 123763 & 0 & 2277459 & 552106 & 1293878 & 0 & 0 & 756801 & 517550 & 0 & 739901 & 5041960 & 31322439 \\
\hline Separate collection & Exports & 3657934 & 373476 & 49666 & 1958483 & 1652517 & 36569 & 9627 & 2047 & 1602 & 0 & 0 & 0 & 0 & 0 & 0 & 35 & 0 & 0 & 2882 & 19637 & 7764476 \\
\hline Separate collection & Plastic sorting & 5986677 & 611240 & 81285 & 3205308 & 2704556 & 59851 & 1106131 & 235201 & 184043 & 0 & 0 & 209420 & 375642 & 0 & 0 & 398585 & 517550 & 0 & 331094 & 2256197 & 18262779 \\
\hline Plastic sorting & Incineration & 1482973 & 84872 & 48572 & 793994 & 375533 & 35764 & 359425 & 85653 & 81026 & 0 & 0 & 25780 & 41199 & 0 & 0 & 177045 & \begin{tabular}{|l|}
517550 \\
\end{tabular} & 0 & 96205 & 655574 & 4861166 \\
\hline Plastic sorting & Landfill & 973201 & 55697 & 31875 & 521059 & 246443 & 23470 & 235873 & 56210 & 53173 & 0 & 0 & 9821 & 22660 & 0 & 0 & 116186 & 0 & 0 & 63134 & 430221 & 2839023 \\
\hline Prod_con_w & Prod_con_w & 1652136 & 211787 & 59372 & 884565 & 937093 & 43716 & 148834 & 31647 & 24764 & 0 & 293257 & 142343 & 311995 & 0 & 0 & 70678 & 0 & 0 & 95522 & 650922 & 5558629 \\
\hline Plastic sorting & Recycling & 3530503 & 470671 & 838 & 1890255 & 2082580 & 617 & 510833 & 93338 & 49843 & 0 & 0 & 173818 & 311783 & O & 促 & 105354 & 0 & 0 & 171755 & 1170402 & 10562591 \\
\hline Residual collection & Incineration & 4546745 & 733820 & 292778 & 2434359 & 3246934 & 215573 & 446303 & 94899 & 74258 & 0 & 2049713 & 399801 & 834760 & 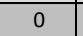 & 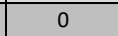 & 454081 & 517550 & 0 & 443940 & 3025176 & 19810691 \\
\hline Residual collection & Landfill & 3031164 & 489213 & 195185 & 1622906 & 2164623 & 143716 & 297535 & 63266 & 49505 & 0 & 227746 & 152305 & 459118 & 0 & 0 & 302721 & 0 & 0 & 295960 & 2016784 & 11511747 \\
\hline Residual collection & Recycling & 0 & 0 & 0 & 0 & 0 & 0 & 0 & 0 & 0 & 0 & 0 & 0 & 0 & 0 & 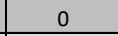 & 0 & 0 & 0 & 0 & 0 & 0 \\
\hline Recycling & Recycled raw material & 0 & 0 & 0 & 2134524 & 1264906 & 0 & 60949 & 22273 & 11894 & 0 & 0 & 68528 & 122920 & 0 & 0 & 92712 & 0 & 0 & 834932 & 2689324 & 7302961 \\
\hline Recycling & Landfill & 328667 & 1712 & 48 & 175970 & 7575 & 35 & 154107 & 28158 & 15037 & 0 & 0 & 10825 & 24975 & 0 & 0 & 5009 & 0 & 0 & 68054 & 463744 & 1283915 \\
\hline Prod_con_w & Prod_con_w & 1830574 & 161982 & 65784 & 980102 & 716720 & 48437 & 124852 & 26548 & 20773 & 0 & 148317 & 190036 & 416528 & 0 & 0 & 124970 & 0 & 0 & 89963 & 613043 & 5558629 \\
\hline
\end{tabular}




\begin{tabular}{|c|c|c|c|c|c|c|c|c|c|c|c|c|c|c|c|c|c|c|c|c|c|c|}
\hline From & To & \multicolumn{3}{|c|}{ Food pack. } & \multicolumn{3}{|c|}{ Non-food pack. } & \multicolumn{3}{|c|}{ Agriculture } & \multicolumn{2}{|c|}{$\begin{array}{c}\text { Automotive } \\
\text { Auto_2D Auto_OR }\end{array}$} & \multicolumn{3}{|c|}{$B \& C$} & \multicolumn{2}{|c|}{$\begin{array}{l}\text { Electronics } \\
\text { ro 2D Electr. }\end{array}$} & \multirow[t]{2}{*}{$\begin{array}{l}\text { Fibers } \\
\text { Fibers } \\
\end{array}$} & \multicolumn{3}{|c|}{$\begin{array}{l}\text { Others } \\
\text { Other 2D Other Fu }\end{array}$} & SUM \\
\hline Recycled & Trade & & & & & & & & & & & & & & & & & & & & & 0 \\
\hline Virgin & Trade & 791484 & 0 & 1243761 & 878460 & 921948 & 460974 & 0 & 0 & 607764 & 0 & 1298633 & 0 & 792627 & 0 & 0 & 482876 & 2000000 & 0 & 177481 & 1879215 & 11535224 \\
\hline Import & Trade & 0 & 0 & 0 & 0 & 0 & 0 & 0 & 0 & 0 & 0 & 0 & 0 & 9000 & 0 & 0 & 226000 & 1035100 & 0 & 39780 & 421200 & 1731080 \\
\hline Trade & Use & 495870 & 0 & 779224 & 550361 & 577607 & 288803 & 0 & 0 & 566436 & 0 & 1034611 & 0 & 755936 & 0 & 0 & 680387 & 2895100 & 0 & 244618 & 2168870 & 11037822 \\
\hline Trade & Exports & 231504 & 0 & 363792 & 256944 & 269664 & 134832 & 0 & 0 & 0 & 0 & 190000 & 0 & -9000 & 0 & 0 & 0 & 0 & 0 & -39780 & 0 & 1397956 \\
\hline Trade & Source-separation & 64110 & 0 & 100745 & 71155 & 74678 & 37339 & 0 & 0 & 41328 & 0 & 74022 & 0 & 54691 & 0 & 0 & 28490 & 140000 & 0 & 12424 & 131545 & 830527 \\
\hline Use & Source-separation & 495870 & 0 & 779224 & 550361 & 577606 & 288803 & 295315 & 63852 & 60775 & 0 & 593697 & 0 & 28755 & 0 & 0 & 304786 & 2350388 & 0 & 236279 & 1683565 & 8309276 \\
\hline Use & Stock & 0 & 0 & 0 & 0 & 0 & 0 & -295315 & -63852 & 505660 & 0 & 440914 & 0 & 727180 & 0 & 0 & 375601 & 544712 & 0 & 8339 & 485305 & 2728546 \\
\hline Source-separation & Separate collection & 344629 & 0 & 0 & 382501 & 258768 & 0 & 177189 & 38311 & 36465 & 0 & 0 & 0 & 20129 & 0 & 0 & 105151 & 1175194 & 0 & 73483 & 523589 & 3135408 \\
\hline Source-separation & Residual collection & 151240 & 0 & 779224 & 167860 & 318839 & 288803 & 118126 & 25541 & 24310 & 0 & 593697 & 0 & 8627 & 0 & 0 & 199635 & 1175194 & 0 & 162796 & 1159976 & 5173868 \\
\hline Separate collection & Exports & 56366 & 0 & 0 & 62561 & 42323 & 0 & 0 & 0 & 136 & 0 & 0 & 0 & 0 & 0 & 0 & 4 & 21548 & 0 & 273 & 1948 & 185160 \\
\hline Separate collection & Plastic sorting & 288263 & 0 & 0 & 319940 & 216444 & 0 & 177189 & 38311 & 36330 & 0 & 0 & 0 & 20129 & 0 & 0 & 105147 & 1153646 & 0 & 73209 & 521640 & 2950248 \\
\hline Plastic sorting & Incineration & 60554 & 0 & 0 & 67208 & 65989 & 0 & 58171 & 14062 & 16066 & 0 & 0 & 0 & 2366 & 0 & 0 & 55694 & 696541 & 0 & 19283 & 137398 & 1193333 \\
\hline Plastic sorting & Landfill & 39739 & 0 & 0 & 44105 & 43305 & 0 & 38175 & 9228 & 10543 & 0 & 0 & 0 & 1257 & 0 & 0 & 36549 & 457105 & 0 & 12655 & 90168 & 782829 \\
\hline Prod_con_w & Prod_con_w & 64110 & 0 & 100745 & 71155 & 74678 & 37339 & 0 & 0 & 41328 & 0 & 74022 & 0 & 54691 & 0 & 0 & 28490 & 140000 & 0 & 12424 & 131545 & 830527 \\
\hline Plastic sorting & Recycling & 187970 & 0 & 0 & 208626 & 107150 & 0 & 80843 & 15020 & 9720 & 0 & 0 & 0 & 16506 & 0 & 0 & 12904 & 0 & 0 & 41272 & 294075 & 974087 \\
\hline Residual collection & Incineration & 90744 & 0 & 467534 & 100716 & 191303 & 173282 & 70876 & 15324 & 14586 & 0 & 534328 & 0 & 5634 & 0 & 0 & 119781 & \begin{tabular}{|l|}
709551 \\
\end{tabular} & 0 & 97678 & 695986 & 3287322 \\
\hline Residual collection & Landfill & 60496 & 0 & 311690 & 67144 & 127536 & 115521 & 47250 & 10216 & 9724 & 0 & 59370 & O & 2993 & 0 & 0 & 79854 & 465643 & 0 & 65118 & 463990 & 1886545 \\
\hline Residual collection & Recycling & 0 & 0 & 0 & 0 & 0 & 0 & 0 & 0 & 0 & 0 & 0 & 0 & 0 & 0 & 0 & 0 & 0 & 0 & 0 & 0 & 0 \\
\hline Recycling & Recycled raw material & 0 & 0 & 0 & 6352 & 0 & 0 & 0 & 0 & 2292 & 0 & 0 & 0 & 5837 & 0 & 0 & 10710 & 0 & 0 & 94719 & 289994 & 409904 \\
\hline Recycling & Landfill & 20002 & 0 & 0 & 22200 & 7276 & 0 & 24481 & 4548 & 2943 & 0 & 0 & 0 & 1676 & 0 & 0 & 869 & 0 & 0 & 16353 & 116520 & 216869 \\
\hline Prod_con_w & Prod_con_w & 64110 & 0 & 100745 & 71155 & 74678 & 37339 & 0 & 0 & 41328 & 0 & 74022 & 0 & 54691 & 0 & 0 & 28490 & 140000 & 0 & 12424 & 131545 & 830527 \\
\hline
\end{tabular}

Table S5.24 Detailed PP flow values [ton] in year 50 in S2a: Mono-polymer design. Prod_con_w: Pre-consumer waste. Flow abbreviations are provided in Table S1.1 and on page 53.

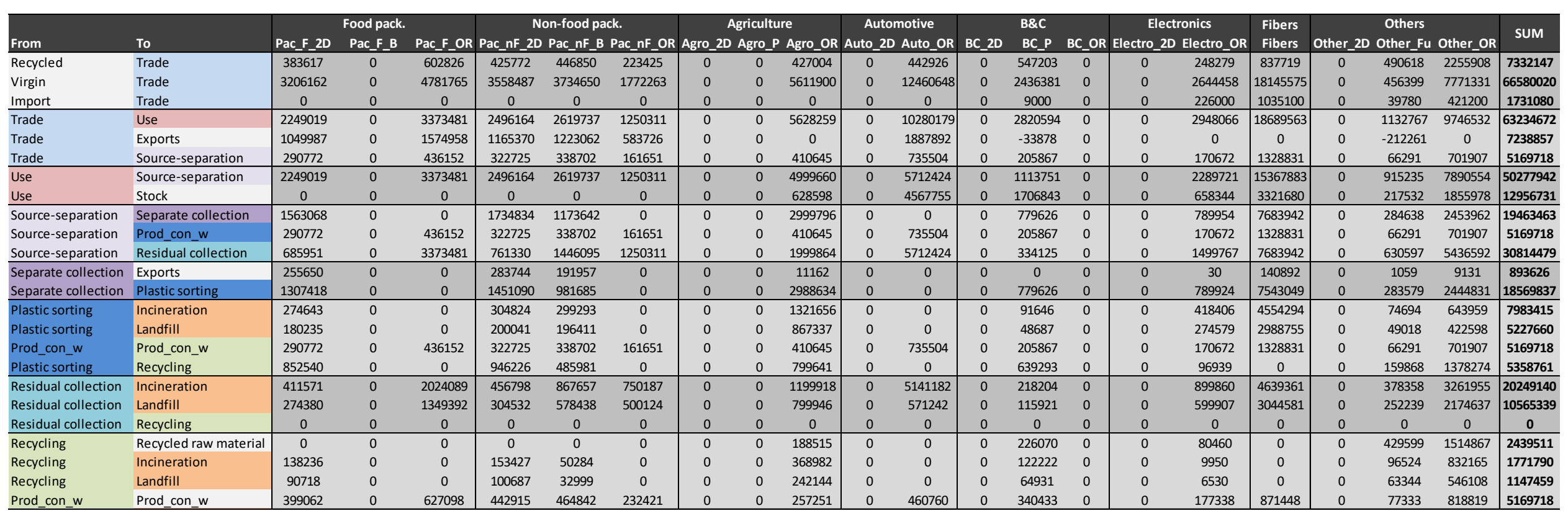


S5.5 Alignment of rigid packaging (S2 b)

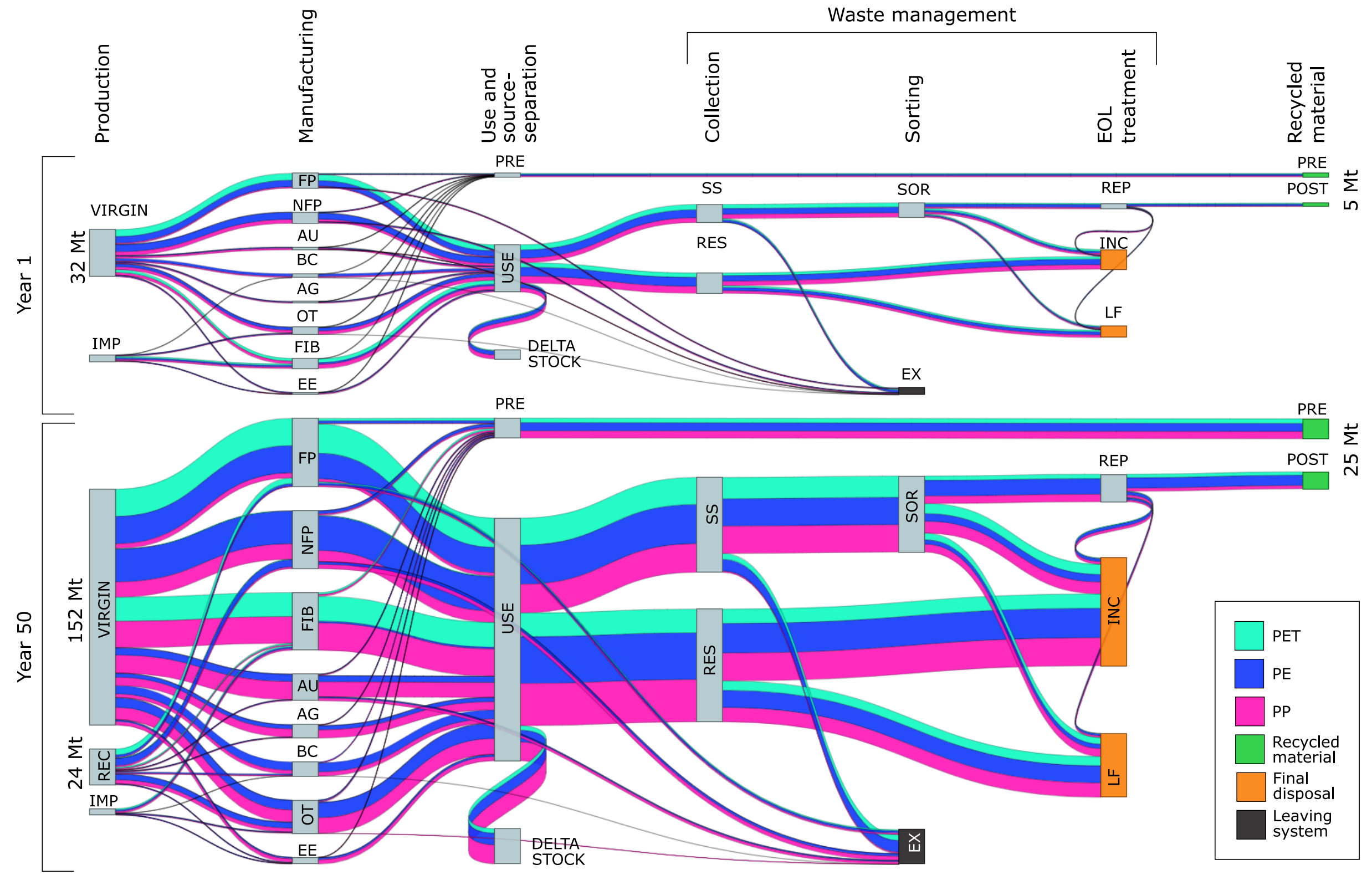

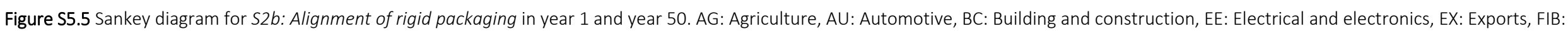

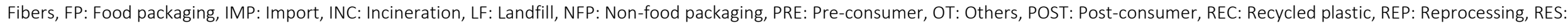
Residual waste, SOR: Sorting, SS: Source-separated waste. 


\begin{tabular}{|c|c|c|c|c|c|c|c|c|c|c|c|c|c|c|c|c|c|c|c|c|c|c|}
\hline From & To & Pac_F_2D & $\begin{array}{c}\text { Food pack } \\
\text { Pac_F_B }\end{array}$ & Pac_F_OR & $\begin{array}{r}1 \\
\text { Pac_nF_21 }\end{array}$ & $\begin{array}{l}\text { on-food pac } \\
\text { Pac_nF_B }\end{array}$ & ack. & R Agro_2 & $\begin{array}{l}\text { Agricultu } \\
\text { D Agro_P }\end{array}$ & $\begin{array}{l}\text { ure } \\
\text { P Agro_OR }\end{array}$ & $\begin{array}{r}\text { Auto } \\
\text { R Auto_2D }\end{array}$ & $\begin{array}{l}\text { motive } \\
\text { Auto_OR }\end{array}$ & $\mathrm{R}$ BC_2D & $\begin{array}{r}\text { B\&C } \\
\text { D BC_P } \\
\end{array}$ & P BC_OR & $\begin{array}{r}\text { Ele } \\
\text { Rlectro_2 }\end{array}$ & $\begin{array}{l}\text { ronics } \\
\text { Electro_OR }\end{array}$ & \begin{tabular}{|l|} 
Fibers \\
Fibers \\
\end{tabular} & Other_- & $\begin{array}{c}\text { Others } \\
\text { 2D Other_Fu }\end{array}$ & Other_OR & SUM \\
\hline Recycled & Trade & & & & & & & & & & & & & & & & & & & & & 0 \\
\hline Virgin & Trade & 179630 & 1189067 & 3342155 & 131973 & 0 & 0 & 0 & 6871 & 0 & 0 & 2131 & 0 & 0 & 0 & 0 & 9590 & 1800000 & 0 & 0 & 16725 & 6678143 \\
\hline Import & Trade & 0 & 0 & 0 & 0 & 0 & 0 & 0 & 0 & 0 & 0 & 0 & 0 & 0 & 0 & 0 & 4492 & 1035100 & 0 & 0 & 3752 & 1043343 \\
\hline Trade & Use & 151133 & 1044393 & 2974722 & 111037 & 0 & 0 & 0 & 6404 & 0 & 0 & 1698 & 0 & 0 & 0 & 0 & 13515 & 2709100 & 0 & 0 & 19306 & 7031308 \\
\hline Trade & Exports & 13947 & 48359 & 96719 & 10247 & 0 & 0 & 0 & 0 & 0 & 0 & 312 & 0 & 0 & 0 & 0 & 0 & 0 & 0 & 0 & 0 & 169584 \\
\hline Trade & Source-separation & 14550 & 96314 & 270715 & 10690 & 0 & 0 & 0 & 467 & 0 & 0 & 121 & 0 & 0 & 0 & 0 & 566 & 126000 & 0 & 0 & 1171 & 520594 \\
\hline Use & Source-separation & 151133 & 1044393 & 2974721 & 111037 & 0 & 0 & 0 & 1864 & 0 & 0 & 1286 & 0 & 0 & 0 & 0 & 1699 & 2199384 & 0 & 0 & 14253 & 6499770 \\
\hline Use & Stock & 0 & 0 & 1 & 0 & 0 & 0 & 0 & 4540 & 0 & 0 & 411 & 0 & 0 & 0 & 0 & 11816 & 509716 & 0 & 0 & 5053 & 531538 \\
\hline Source-separation & Separate collection & 105038 & 606792 & 1624198 & 77170 & 0 & 0 & 0 & 1118 & 0 & 0 & 0 & 0 & 0 & 0 & 0 & 586 & 1099692 & 0 & 0 & 4433 & 3519027 \\
\hline Source-separation & Prod_con_w & 14550 & 96314 & 270715 & 10690 & 0 & 0 & 0 & 467 & 0 & 0 & 121 & 0 & 0 & 0 & 0 & 566 & 126000 & 0 & 0 & 1171 & 520594 \\
\hline Source-separation & Residual collection & 46096 & 437601 & 1350523 & 33866 & 0 & 0 & 0 & 745 & 0 & 0 & 1286 & 0 & 0 & 0 & 0 & 1113 & 1099692 & 0 & 0 & 9820 & 2980743 \\
\hline Separate collection & Exports & 30740 & 177579 & 475326 & 22584 & 0 & 0 & 0 & 8 & 0 & 0 & 0 & 0 & 0 & 0 & 0 & 0 & \begin{tabular}{|l}
93757 \\
\end{tabular} & 0 & 0 & 30 & 800024 \\
\hline Separate collection & Plastic sorting & 74298 & 429213 & 1148872 & 54586 & 0 & 0 & 0 & 1111 & 0 & 0 & 0 & 0 & 0 & 0 & 0 & 586 & 1005935 & 0 & 0 & 4403 & 2719003 \\
\hline Plastic sorting & Incineration & 18718 & 44400 & 530405 & 13752 & 0 & 0 & 0 & 339 & 0 & 0 & 0 & 0 & 0 & 0 & 0 & 85 & 607357 & 0 & 0 & 1196 & 1216252 \\
\hline Plastic sorting & Landfill & 12284 & 29137 & 348078 & 9025 & 0 & 0 & 0 & 222 & 0 & 0 & 0 & 0 & 0 & 0 & 0 & 56 & 398578 & 0 & 0 & 785 & 798165 \\
\hline Prod_con_w & Prod_con_w & 14550 & 96314 & 270715 & 10690 & 0 & 0 & 0 & 467 & 0 & 0 & 121 & 0 & 0 & 0 & 0 & 566 & 126000 & 0 & 0 & 1171 & 520594 \\
\hline Plastic sorting & Recycling & 43296 & 355676 & 270389 & 31809 & 0 & 0 & 0 & 550 & 0 & 0 & 0 & 0 & 0 & 0 & 0 & 446 & 0 & 0 & 0 & 2422 & 704587 \\
\hline Residual collection & Incineration & 27831 & 264212 & 815410 & 20447 & 0 & 0 & 0 & 450 & 0 & 0 & 1286 & 0 & 0 & 0 & 0 & 672 & 663965 & 0 & 0 & 5929 & 1800204 \\
\hline Residual collection & Landfill & 18264 & 173389 & 535113 & 13419 & 0 & 0 & 0 & 295 & 0 & 0 & 0 & 0 & 0 & 0 & 0 & 441 & 435727 & 0 & 0 & 3891 & 1180539 \\
\hline Residual collection & Recycling & 0 & 0 & 0 & 0 & 0 & 0 & 0 & 0 & 0 & 0 & 0 & 0 & 0 & 0 & 0 & 0 & 0 & 0 & 0 & 0 & 0 \\
\hline Recycling & Recycled raw material & 0 & 295211 & 210092 & 58134 & 0 & 0 & 0 & 126 & 0 & 0 & 0 & 0 & 0 & 0 & 0 & 330 & 0 & 0 & 0 & 0 & 563893 \\
\hline Recycling & Incineration & 5829 & 36507 & 36406 & 4417 & 0 & 0 & 0 & 256 & 0 & 0 & 0 & 0 & 0 & 0 & 0 & 70 & 0 & 0 & 0 & 1462 & 84947 \\
\hline Recycling & Landfill & 3826 & 23958 & 23891 & 2899 & 0 & 0 & 0 & 168 & 0 & 0 & 0 & 0 & 0 & 0 & 0 & 46 & 0 & 0 & 0 & 959 & 55746 \\
\hline Prod_con_w & Prod_con_w & 14003 & 92694 & 260537 & 10288 & 0 & 0 & 0 & 536 & 0 & 0 & 166 & 0 & 0 & 0 & 0 & 748 & 140319 & 0 & 0 & 1304 & 520594 \\
\hline
\end{tabular}

Table S5.26 Detailed PET flow values [ton] in year 50 in S2b: Alignment of rigid packaging. Prod_con_w: Pre-consumer waste. Flow abbreviations are provided in Table S1.1 and on page 53.

\begin{tabular}{|c|c|c|c|c|c|c|c|c|c|c|c|c|c|c|c|c|c|c|c|c|c|c|}
\hline & & & Food pack & & & on-food pa & jack. & & Agricultur & & Autor & motive & & $B \& C$ & & Elect & tronics & Fibers & & Others & & SU \\
\hline From & To & Pac_F_2D & Pac_F_B & Pac_F_OR & Pac_nF_2D & Pac_nF_B & B Pac_nF_OF & Agro_2D & Agro_P & Agro_OP & R Auto_2D & Auto_OR & $R$ BC_2D & D BC_P & BC_OR & Electro_2D & ) Electro_OR & Fibers & Other_2D & Other_Fu & Other_OR & \\
\hline Recycled & Trade & 79544 & 1426518 & 2587408 & 243987 & 0 & 0 & 0 & 6699 & 0 & 0 & 944 & 0 & 0 & 0 & 0 & 12778 & 797076 & 0 & 0 & 7406 & 5162359 \\
\hline Virgin & Trade & 508115 & 2285451 & 15663936 & 187762 & 0 & 0 & 0 & 61574 & 0 & 0 & 20231 & 0 & 0 & 0 & 0 & 44669 & 16287889 & 0 & 0 & 81838 & 35141465 \\
\hline Import & Trade & 0 & 0 & 0 & 0 & 0 & 0 & 0 & 0 & 0 & 0 & 0 & 0 & 0 & 0 & 0 & 4492 & 1035100 & 0 & 0 & 3752 & 1043343 \\
\hline Trade & Use & 494431 & 3260334 & 16244810 & 363255 & 0 & 0 & 0 & 63630 & 0 & 0 & 16868 & 0 & 0 & 0 & 0 & 58549 & 16924117 & 0 & 0 & 86749 & 37512743 \\
\hline Trade & Exports & 45628 & 150966 & 528176 & 33522 & 0 & 0 & 0 & 0 & 0 & 0 & 3099 & 0 & 0 & 0 & 0 & 0 & 0 & 0 & 0 & 0 & 761391 \\
\hline Trade & Source-separation & 47600 & 300669 & 1478359 & 34972 & 0 & 0 & 0 & 4643 & 0 & 0 & 1207 & 0 & 0 & 0 & 0 & 3389 & 1195947 & 0 & 0 & 6247 & 3073034 \\
\hline Use & Source-separation & 494431 & 3260334 & 16244810 & 363255 & 0 & 0 & 0 & 56523 & 0 & 0 & 9373 & 0 & 0 & 0 & 0 & 45475 & 13934605 & 0 & 0 & 70231 & 34479037 \\
\hline Use & Stock & 0 & 0 & 0 & 0 & 0 & 0 & 0 & 7107 & 0 & 0 & 7495 & 0 & 0 & 0 & 0 & 13074 & 2989512 & 0 & 0 & 16519 & 3033706 \\
\hline Source-separation & Separate collection & 343629 & 1894254 & 8869666 & 252462 & 0 & 0 & 0 & 33914 & 0 & 0 & 0 & 0 & 0 & 0 & 0 & 15689 & \begin{tabular}{|l|}
6967303 \\
\end{tabular} & 0 & 0 & 21842 & $\mid 18398759$ \\
\hline Source-separation & Prod_con_w & 47600 & 300669 & 1478359 & 34972 & 0 & 0 & 0 & 4643 & 0 & 0 & 1207 & 0 & 0 & 0 & 0 & 3389 & 1195947 & 0 & 0 & 6247 & 3073034 \\
\hline Source-separation & Residual collection & 150801 & 1366080 & 7375144 & 110793 & 0 & 0 & 0 & 22609 & 0 & 0 & 9373 & 0 & 0 & 0 & 0 & 29786 & 6967303 & 0 & 0 & 48389 & 16080278 \\
\hline Separate collection & Exports & 100564 & 554359 & 2595732 & 73884 & 0 & 0 & 0 & 229 & 0 & 0 & 0 & 0 & 0 & 0 & 0 & 1 & 594016 & 0 & 0 & 147 & 3918933 \\
\hline Separate collection & Plastic sorting & 243065 & 1339895 & 6273934 & 178578 & 0 & 0 & 0 & 33685 & 0 & 0 & 0 & 0 & 0 & 0 & 0 & 15688 & 6373287 & 0 & 0 & 21694 & 14479826 \\
\hline Plastic sorting & Incineration & 61236 & 138605 & 2896515 & 44990 & 0 & 0 & 0 & 10271 & 0 & 0 & 0 & 0 & 0 & 0 & 0 & 2273 & 3848022 & 0 & 0 & 5894 & 7007806 \\
\hline Plastic sorting & Landfill & 40186 & 90959 & 1900838 & 29525 & 0 & 0 & 0 & 6740 & 0 & 0 & 0 & 0 & 0 & 0 & 0 & 1492 & 2525264 & 0 & 0 & 3868 & 4598873 \\
\hline Prod_con_w & Prod_con_w & 47600 & 300669 & 1478359 & 34972 & 0 & 0 & 0 & 4643 & 0 & 0 & 1207 & 0 & 0 & 0 & 0 & 3389 & 1195947 & 0 & 0 & 6247 & 3073034 \\
\hline Plastic sorting & Recycling & 141642 & 1110331 & 1476581 & 104064 & 0 & 0 & 0 & 16674 & 0 & 0 & 0 & 0 & 0 & 0 & 0 & 11923 & 0 & 0 & 0 & 11932 & 2873147 \\
\hline Residual collection & Incineration & 91050 & 824803 & 4452917 & 66894 & 0 & 0 & 0 & 13651 & 0 & 0 & 9373 & 0 & 0 & 0 & 0 & 17984 & 4206673 & 0 & 0 & 29216 & \begin{tabular}{|l|}
9712561 \\
\end{tabular} \\
\hline Residual collection & Landfill & 59751 & 541277 & 2922227 & 43899 & 0 & 0 & 0 & 8958 & 0 & 0 & 0 & 0 & 0 & 0 & 0 & 11802 & 2760629 & 0 & 0 & 19173 & 6367717 \\
\hline Residual collection & Recycling & 0 & 0 & 0 & 0 & 0 & 0 & 0 & 0 & 0 & 0 & 0 & 0 & 0 & 0 & 0 & 0 & 0 & 0 & 0 & 0 & 0 \\
\hline Recycling & Recycled raw material & 0 & 921575 & 1147304 & 190185 & 0 & 0 & 0 & 3835 & 0 & 0 & 0 & 0 & 0 & 0 & 0 & 8823 & 0 & 0 & 0 & 0 & 2271721 \\
\hline Recycling & Incineration & 19071 & 113966 & 198809 & 14451 & 0 & 0 & 0 & 7752 & 0 & 0 & 0 & 0 & 0 & 0 & 0 & 1872 & 0 & 0 & 0 & 7204 & 363125 \\
\hline Recycling & Landfill & 12515 & 74790 & 130468 & 9484 & 0 & 0 & 0 & 5087 & 0 & 0 & 0 & 0 & 0 & 0 & 0 & 1228 & 0 & 0 & 0 & 4728 & 238301 \\
\hline Prod_con_w & Prod_con_w & 82659 & 547165 & 1537936 & 60729 & 0 & 0 & 0 & 3162 & 0 & 0 & 981 & 0 & 0 & 0 & 0 & 4413 & 828293 & 0 & 0 & 7696 & 3073034 \\
\hline
\end{tabular}




\begin{tabular}{|c|c|c|c|c|c|c|c|c|c|c|c|c|c|c|c|c|c|c|c|c|c|c|}
\hline From & To & \multicolumn{3}{|c|}{ Food pack. } & \multicolumn{3}{|c|}{ Non-food pack. } & \multicolumn{3}{|c|}{ Agriculture } & \multicolumn{2}{|c|}{ Automotive } & \multicolumn{3}{|c|}{$B \& C$} & \multicolumn{2}{|c|}{ Electronics } & \multirow[t]{2}{*}{$\begin{array}{l}\text { Fibers } \\
\text { Fibers }\end{array}$} & \multicolumn{3}{|c|}{ Others } & SUM \\
\hline Recycled & Trade & & & & & & & & & & & & & & & & & & & & & 0 \\
\hline Virgin & Trade & 4497128 & 0 & 0 & 2407793 & 2432720 & 118994 & 365360 & 77688 & 60790 & 0 & 517785 & 548048 & 1201236 & 0 & 0 & 421489 & 0 & 0 & 255741 & 1742712 & 14647486 \\
\hline Import & Trade & 0 & 0 & 0 & 0 & 0 & 0 & 0 & 0 & 0 & 0 & 0 & 6579 & 14421 & 0 & 0 & 197000 & 1035100 & 0 & 57378 & 390998 & 1701477 \\
\hline Trade & Use & \begin{tabular}{|l|}
3797268 \\
\end{tabular} & 0 & 0 & 2033083 & 2104276 & 100476 & \begin{tabular}{|l}
340516 \\
\end{tabular} & 72405 & 56656 & 0 & 412484 & 516812 & 1132772 & 0 & 0 & 593621 & 1035100 & 0 & 295217 & 2011721 & 14502408 \\
\hline Trade & Exports & 335593 & 0 & 0 & 179679 & 131394 & 8880 & 0 & 0 & 0 & 0 & 75787 & 0 & 0 & 0 & 0 & 0 & 0 & 0 & 0 & 0 & 731333 \\
\hline Trade & Source-separation & 364267 & 0 & 0 & 195031 & 197050 & 9639 & 24844 & 5283 & 4134 & 0 & 29514 & 37815 & 82885 & 0 & 0 & 24868 & 0 & 0 & 17902 & 121990 & 1115222 \\
\hline Use & Source-separation & \begin{tabular}{|l|l|}
3797267 \\
\end{tabular} & 0 & 0 & 2033083 & 2104275 & 100476 & 303062 & 65499 & 49178 & 0 & 177242 & 20233 & 45036 & 0 & 0 & 304765 & 840346 & 0 & 237430 & 1679990 & 11757882 \\
\hline Use & Stock & 1 & 0 & 0 & 1 & 1 & 0 & 37454 & 6906 & 7479 & 0 & 235242 & 496579 & 1087736 & 0 & 0 & 288856 & 194754 & 0 & 57787 & 331731 & 2744526 \\
\hline Source-separation & Separate collection & \begin{tabular}{|l|}
2126469 \\
\end{tabular} & 0 & 0 & 1138526 & 938564 & 21259 & $\mid 181837$ & 39299 & 29507 & 0 & 0 & 5564 & 10133 & 0 & 0 & 105144 & 420173 & 0 & 73841 & 522477 & 5612793 \\
\hline Source-separation & Residual collection & 1670797 & 0 & 0 & 894556 & 1165711 & 79217 & 121225 & 26200 & 19671 & 0 & 177242 & 14669 & 34903 & 0 & 0 & 199621 & 420173 & 0 & 163589 & 1157513 & 6145089 \\
\hline Separate collection & Exports & 806511 & 0 & 0 & 431812 & 355971 & 8063 & 1569 & 339 & 255 & 0 & 0 & 0 & 0 & 0 & 0 & 9 & 0 & 0 & 637 & 4508 & 1609674 \\
\hline Separate collection & Plastic sorting & 1319958 & 0 & 0 & 706715 & 582592 & 13196 & 180268 & 38960 & 29252 & 0 & 0 & 5564 & 10133 & 0 & 0 & 105135 & 420173 & 0 & 73204 & 517969 & 4003119 \\
\hline Plastic sorting & Incineration & 332543 & 0 & 0 & 178046 & 84106 & 7886 & 60393 & 14526 & 13051 & 0 & 0 & 806 & 1307 & 0 & 0 & 46699 & 420173 & 0 & 22099 & 156368 & 1338003 \\
\hline Plastic sorting & Landfill & 218231 & 0 & 0 & 116842 & 55194 & 5175 & 39633 & 9532 & 8565 & 0 & 0 & 307 & 719 & 0 & 0 & 30646 & 0 & 0 & 14503 & 102616 & 601965 \\
\hline Prod_con_w & Prod_con_w & 364267 & 0 & 0 & 195031 & 197050 & 9639 & 24844 & 5283 & 4134 & 0 & 29514 & 37815 & 82885 & 0 & 0 & 24868 & 0 & 0 & 17902 & 121990 & 1115222 \\
\hline Plastic sorting & Recycling & 769184 & 0 & 0 & 411827 & 443292 & 134 & 80242 & 14902 & 7636 & 0 & 0 & 4451 & 8106 & 0 & 0 & 27789 & 0 & 0 & 36602 & 258984 & 2063151 \\
\hline Residual collection & Incineration & 1002478 & 0 & 0 & 536734 & 699427 & 47530 & 72735 & 15720 & 11803 & 0 & 159518 & 10623 & 22518 & 0 & 0 & 119773 & 420173 & 0 & 98154 & 694508 & 3911692 \\
\hline Residual collection & Landfill & 668319 & 0 & 0 & 357823 & 466285 & 31687 & 48490 & 10480 & 7868 & O & 17724 & 4047 & 12385 & 0 & 0 & 79849 & 0 & 0 & 65436 & 463005 & 2233396 \\
\hline Residual collection & Recycling & 0 & 0 & 0 & 0 & 0 & 0 & 0 & 0 & 0 & 0 & 0 & 0 & 0 & 0 & 0 & 0 & 0 & 0 & 0 & 0 & 0 \\
\hline Recycling & Recycled raw material & 0 & 0 & 0 & 431439 & 205244 & 0 & 9228 & 3428 & 1756 & 0 & 0 & 1692 & 3080 & 0 & 0 & 24455 & 0 & 0 & 156891 & 475444 & 1312657 \\
\hline Recycling & Landfill & 86860 & 0 & 0 & 46505 & 12998 & 11 & 24481 & 4547 & 2330 & 0 & 0 & 295 & 690 & 0 & 0 & 1321 & 0 & 0 & 14503 & 102616 & 297157 \\
\hline Prod_con_w & Prod_con_w & 342400 & 0 & 0 & 183323 & 185221 & 9060 & 27818 & 5915 & 4628 & 0 & 39423 & 41727 & 91459 & 0 & 0 & 32091 & 0 & 0 & 19471 & 132686 & 1115222 \\
\hline
\end{tabular}

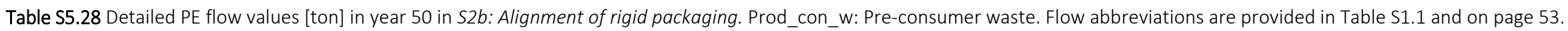

\begin{tabular}{|c|c|c|c|c|c|c|c|c|c|c|c|c|c|c|c|c|c|c|c|c|c|c|}
\hline \multirow[b]{2}{*}{ From } & \multirow[b]{2}{*}{ To } & \multicolumn{3}{|c|}{ Food pack. } & \multicolumn{3}{|c|}{ Non-food pack. } & \multicolumn{3}{|c|}{ Agriculture } & \multirow{2}{*}{\multicolumn{2}{|c|}{$\begin{array}{l}\text { Automotive } \\
\text { Ato 2D Auto OR }\end{array}$}} & \multicolumn{3}{|c|}{$B \& C$} & \multirow{2}{*}{\multicolumn{2}{|c|}{$\begin{array}{l}\text { Electronics } \\
\text { ro 2D Electro OR }\end{array}$}} & \multirow{2}{*}{$\begin{array}{l}\text { Fibers } \\
\text { Fibers }\end{array}$} & \multirow{2}{*}{\multicolumn{3}{|c|}{$\begin{array}{c}\text { Others } \\
\text { Other_2D Other_Fu }\end{array}$}} & \multirow{2}{*}{ SUM } \\
\hline & & Pac_F_2D & Pac_F_B & Pac_F_OF & Pac_nF_2D & D Pac_nF_B & Pac_nF_OF & Agro_2D & Agro_P & Agro_OR & & & BC_2D & BC_P & BC_OR & & & & & & & \\
\hline Recycled & Trade & 1674690 & 0 & 0 & 2806754 & 2202619 & 44312 & 190606 & 48865 & 33283 & 0 & 192819 & 266037 & 558459 & 0 & 0 & 248015 & 0 & 0 & 883419 & 3186598 & 12336475 \\
\hline Virgin & Trade & 18722050 & 0 & 0 & 8113800 & 13781636 & 495387 & 1998133 & 3 416535 & 330889 & 0 & 4952035 & 1796911 & 13963202 & 0 & 0 & 949909 & 0 & 0 & 481180 & 6112283 & 62113950 \\
\hline Import & Trade & 0 & 0 & 0 & 0 & 0 & 0 & 0 & 0 & 0 & 0 & 0 & 6579 & 14421 & 0 & 0 & 197000 & 1035100 & 0 & 57378 & 390998 & 1701477 \\
\hline $\begin{array}{l}\text { Trade } \\
\text { The }\end{array}$ & Use & 17222521 & 0 & 0 & 9221056 & 13826203 & 455709 & 2039905 & 5433752 & 339408 & 0 & 4098556 & 1927184 & 44224087 & 0 & 0 & 1324247 & 1035100 & 0 & 1326455 & 9038957 & 66513141 \\
\hline Trade & Exports & 1522083 & 0 & 0 & 14934 & 863327 & 40274 & 0 & 0 & 0 & 0 & 753041 & 0 & 0 & 0 & 0 & 0 & 0 & c & 0 & 0 & 3993659 \\
\hline Trade & Source-separation & 1652136 & 0 & 0 & 884565 & 1294725 & 43716 & 148834 & 31647 & 24764 & 0 & 293257 & 142343 & 311995 & 0 & 0 & 70678 & 0 & 0 & 95522 & 650922 & 5645102 \\
\hline Use & Source-separation & 17222521 & 0 & 0 & 9221056 & 13826203 & 455709 & 1859597 & 7395413 & 309408 & 0 & 2277459 & 761526 & 1669520 & 0 & 0 & 1155422 & 1035100 & 0 & 1073876 & 7317794 & 58580603 \\
\hline Use & Stock & 0 & 0 & 0 & 0 & 0 & 0 & 180308 & 38340 & 30001 & 0 & 1821097 & 1165658 & 3 2554568 & 0 & 0 & 168825 & 0 & ( & 252578 & 1721163 & 7932538 \\
\hline Source-separation & Separate collection & 9644612 & 0 & 0 & 5163791 & 6166861 & 96420 & 1115758 & 8237248 & 185645 & 0 & 0 & 209420 & 375642 & 0 & 0 & 398621 & 517550 & 0 & 333976 & 2275834 & 26721375 \\
\hline Source-separation & Prod_con_w & 1652136 & 0 & 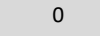 & 884565 & 1294725 & 43716 & 148834 & 31647 & 24764 & 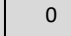 & 293257 & 142343 & 311995 & 0 & 0 & 70678 & 0 & 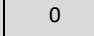 & 95522 & 650922 & 5645102 \\
\hline Source-separation & Residual collection & 7577909 & 0 & 0 & 4057264 & 7659342 & 359289 & 743839 & 158165 & 123763 & 0 & 2277459 & 552106 & 1293878 & 0 & 0 & 756801 & 517550 & 0 & 739901 & 5041960 & 31859227 \\
\hline Separate collection & Exports & 3657934 & 0 & 0 & 1958483 & 2338920 & 36569 & 9627 & 2047 & 1602 & 0 & 0 & 0 & 0 & 0 & 0 & 35 & 0 & 0 & 2882 & 19637 & 8027737 \\
\hline Separate collection & Plastic sorting & 5986677 & 0 & 0 & 3205308 & 3827941 & 59851 & 1106131 & 1235201 & 184043 & 0 & 0 & 209420 & 375642 & 0 & 0 & 398585 & 517550 & ( & 331094 & 2256197 & 18693639 \\
\hline Plastic sorting & Incineration & 1508249 & 0 & 0 & 807527 & 552620 & 35768 & 370573 & 87690 & 82114 & 0 & 0 & 30330 & 48470 & 0 & 0 & 177045 & 517550 & r & 99953 & 681116 & 4999005 \\
\hline Plastic sorting & Landfill & 989789 & 0 & 0 & 529940 & 362657 & 23473 & 243189 & 57547 & 53887 & 0 & 0 & 11554 & 26658 & 0 & 0 & 116186 & 0 & 0 & 65594 & 446982 & 2927455 \\
\hline Prod_con_w & Prod_con_w & 1652136 & 0 & 0 & 884565 & 1294725 & 43716 & 148834 & 31647 & 24764 & 0 & 293257 & 142343 & 311995 & 0 & 0 & 70678 & 0 & 0 & 95522 & 650922 & 5645102 \\
\hline Plastic sorting & Recycling & 3488639 & 0 & 0 & 1867841 & 2912664 & 610 & 492369 & 89964 & 48042 & 0 & 0 & 167536 & 300513 & 0 & 0 & 105354 & 0 & $c$ & 165547 & 1128098 & 10767178 \\
\hline Residual collection & Inciner & 4546745 & 0 & 0 & 2434359 & 4595605 & 215573 & 446303 & 94899 & 74258 & 0 & 2049713 & 399801 & 834760 & 0 & 0 & 454081 & 517550 & ( & 443940 & 3025176 & 20132765 \\
\hline Residual collection & Landfill & 3031164 & 0 & 0 & 1622906 & 3063737 & 143716 & 297535 & 63266 & 49505 & 0 & 227746 & 152305 & 459118 & 0 & 0 & 302721 & 0 & 0 & 295960 & 2016784 & 11726463 \\
\hline Residual collection & Recycling & 0 & 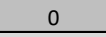 & O & 0 & 0 & 0 & 0 & 0 & 0 & O & 0 & 0 & 0 & 0 & 0 & 0 & 0 & 0 & 0 & 0 & 0 \\
\hline Recycling & Recycled & 0 & 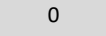 & 0 & 1971564 & 1348563 & 0 & 56622 & 20692 & 11050 & 0 & 0 & 63664 & 114195 & 0 & 0 & 92712 & 0 & 0 & 815998 & 2625853 & 7120914 \\
\hline Recycling & Incineration & 600309 & 0 & 0 & 321410 & 130136 & 74 & 228905 & 41825 & 22335 & 0 & 0 & 29117 & 46531 & 0 & 0 & 7633 & 0 & 0 & 99953 & 681116 & 2209343 \\
\hline Recycling & Landfill & 393953 & 0 & 0 & 210925 & 85402 & 48 & 150219 & 27448 & 14657 & 0 & 0 & 11092 & 25592 & 0 & 0 & 5009 & 0 & 0 & 65594 & 446982 & 1436922 \\
\hline Prod_con_w & Prod_con & 1733181 & 0 & 0 & 927957 & 937564 & 45860 & 140809 & 29941 & 23428 & 0 & 199553 & 211216 & 462953 & 0 & 0 & 162441 & 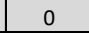 & 0 & 98562 & 671637 & 5645102 \\
\hline
\end{tabular}

Table S5.29 Detailed PP flow values [ton] in year 1 in S2b: Alignment of rigid packaging. Prod_con_w: Pre-consumer waste. Flow abbreviations are provided in Table S1.1 and on page 53. 


\begin{tabular}{|c|c|c|c|c|c|c|c|c|c|c|c|c|c|c|c|c|c|c|c|c|c|c|}
\hline \multirow{2}{*}{$\begin{array}{l}\text { From } \\
\text { Recycled }\end{array}$} & To & \multicolumn{3}{|c|}{ Food pack. } & \multicolumn{3}{|c|}{ Non-food pack. } & \multicolumn{3}{|c|}{ Agriculture } & \multicolumn{2}{|c|}{$\begin{array}{c}\text { Automotive } \\
\text { Auto_2D Auto_OR }\end{array}$} & \multicolumn{3}{|c|}{$B \& C$} & \multicolumn{2}{|c|}{ Electronics } & \begin{tabular}{|l|} 
Fibers \\
Fibers \\
\end{tabular} & \multicolumn{3}{|c|}{\begin{tabular}{|l|} 
Others \\
\end{tabular}} & SUM \\
\hline & Trade & & & & & & & & & & & & & & & & & & & & & 0 \\
\hline Virgin & Trade & 791484 & 0 & 0 & 878460 & 921948 & 780000 & 0 & 0 & 607764 & 0 & 1298633 & 0 & 792627 & 0 & 0 & 482876 & 2000000 & 0 & 177481 & 1879215 & 10610489 \\
\hline & Trade & 0 & 0 & 0 & 0 & 0 & 0 & 0 & 0 & 0 & 0 & 0 & 0 & 9000 & 0 & 0 & 226000 & 1035100 & 0 & 39780 & 421200 & 1731080 \\
\hline Trade & Use & 495870 & 0 & 0 & 550361 & 577607 & 581988 & 0 & 0 & 566436 & 0 & 1034611 & 0 & 755936 & 0 & 0 & 680387 & 2895100 & 0 & 244618 & 2168870 & 10551782 \\
\hline Trade & Exports & 231504 & 0 & 0 & 256944 & 269664 & 134832 & 0 & 0 & 0 & 0 & 190000 & 0 & -9000 & 0 & 0 & 0 & 0 & 0 & -39780 & 0 & 1034164 \\
\hline Trade & Source-separation & 64110 & 0 & 0 & 71155 & 74678 & 63180 & 0 & 0 & 41328 & 0 & 74022 & 0 & 54691 & 0 & 0 & 28490 & 140000 & 0 & 12424 & 131545 & 755623 \\
\hline Use & Source-separation & 495870 & 0 & 0 & 550361 & 577606 & 581988 & $\mid 295315$ & 63852 & 60775 & 0 & 593697 & 0 & 28755 & 0 & 0 & 304786 & 2350388 & 0 & 236279 & 1683565 & 7823237 \\
\hline Use & Stock & 0 & 0 & 0 & 0 & 0 & 0 & -295315 & -63852 & 505660 & 0 & 440914 & 0 & 727180 & 0 & 0 & 375601 & 544712 & 0 & 8339 & 485305 & 2728545 \\
\hline Source-separation & Separate collection & 344629 & 0 & 0 & 382501 & 258768 & 0 & 177189 & 38311 & 36465 & 0 & 0 & 0 & 20129 & 0 & 0 & 105151 & 1175194 & 0 & 73483 & 523589 & 3135408 \\
\hline Source-separation & Residual collection & 151240 & 0 & 0 & 167860 & 318839 & 581988 & 118126 & 25541 & 24310 & 0 & 593697 & 0 & 8627 & 0 & 0 & 199635 & 1175194 & 0 & 162796 & 1159976 & 4687828 \\
\hline Separate collection & Exports & 56366 & 0 & 0 & 62561 & 42323 & 0 & 0 & 0 & 136 & 0 & 0 & 0 & 0 & 0 & 0 & 4 & 21548 & 0 & 273 & 1948 & 185160 \\
\hline Separate collection & Plastic sorting & 288263 & 0 & 0 & 319940 & 216444 & 0 & 177189 & 38311 & 36330 & 0 & 0 & 0 & 20129 & 0 & 0 & 105147 & 1153646 & 0 & 73209 & 521640 & 2950248 \\
\hline Plastic sorting & Incineration & 72623 & 0 & 0 & 80604 & 72869 & 0 & 59361 & 14284 & 16209 & 0 & 0 & 0 & 2629 & 0 & 0 & 55694 & 696541 & 0 & 19891 & 141729 & 1232434 \\
\hline Plastic sorting & Landfill & 47659 & 0 & 0 & 52896 & 47820 & 0 & 38956 & 9374 & 10637 & 0 & 0 & 0 & 1397 & 0 & 0 & 36549 & 457105 & 0 & 13053 & 93009 & 808456 \\
\hline Prod_con_w & Prod_con_w & 64110 & 0 & 0 & 71155 & 74678 & 63180 & 0 & 0 & 41328 & 0 & 74022 & 0 & 54691 & 0 & 0 & 28490 & 140000 & 0 & 12424 & 131545 & 755623 \\
\hline Plastic sorting & Recycling & 167981 & 0 & 0 & 186440 & 95755 & 0 & 78872 & 14654 & 9483 & 0 & 0 & 0 & 16103 & 0 & 0 & 12904 & 0 & 0 & 40265 & 286902 & 909359 \\
\hline Residual collection & Incineration & 90744 & 0 & 0 & 100716 & 191303 & 349193 & 70876 & 15324 & 14586 & 0 & 534328 & 0 & 5634 & 0 & 0 & 119781 & 709551 & 0 & 97678 & 695986 & 2995699 \\
\hline Residual collection & Landfill & 60496 & 0 & 0 & 67144 & 127536 & 232795 & 47250 & 10216 & 9724 & 0 & 59370 & 0 & 2993 & 0 & 0 & 79854 & 465643 & 0 & 65118 & 463990 & 1692130 \\
\hline Residual collection & Recycling & 0 & 0 & 0 & 0 & 0 & 0 & 0 & 0 & 0 & 0 & 0 & 0 & 0 & 0 & 0 & 0 & 0 & 0 & 0 & 0 & 0 \\
\hline Recycling & Recycled raw material & 0 & 0 & 0 & 6046 & 0 & 0 & 0 & 0 & 2181 & 0 & 0 & 0 & 5556 & 0 & 0 & 10710 & 0 & 0 & 82743 & 253785 & 361021 \\
\hline Recycling & Landfill & 18969 & 0 & 0 & 21054 & 7209 & 0 & 24064 & 4471 & 2893 & 0 & 0 & 0 & 1732 & 0 & 0 & 869 & 0 & 0 & 15954 & 113678 & 210893 \\
\hline Prod_con_w & Prod_con_w & 56365 & 0 & 0 & 62559 & 65656 & 55547 & 0 & 0 & 43282 & 0 & 92482 & 0 & 56447 & 0 & 0 & 34388 & 142429 & 0 & 12639 & 133828 & 755623 \\
\hline
\end{tabular}

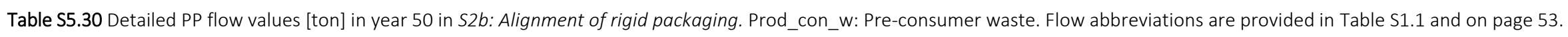

\begin{tabular}{|c|c|c|c|c|c|c|c|c|c|c|c|c|c|c|c|c|c|c|c|c|c|c|}
\hline & & & $\begin{array}{l}\text { Food pack } \\
\text { Pac F B }\end{array}$ & Pac F OR & $\begin{array}{r}\mathrm{Nc} \\
\mathrm{Pac} n \mathrm{nF} \\
2 \mathrm{D}\end{array}$ & $\begin{array}{l}\text { on-food pac } \\
\text { Pac nF B B }\end{array}$ & $\begin{array}{l}\text { k. } \\
\text { Pac nf_OR }\end{array}$ & Agro 2D & $\begin{array}{l}\text { Agricult } \\
\text { Agro }\end{array}$ & ure & $\begin{array}{r}\text { Aut } \\
\text { Auto 2 }\end{array}$ & $\begin{array}{l}\text { omotive } \\
\text { D Auto OR }\end{array}$ & & $\begin{array}{l}\text { B\&C } \\
\text { BC_P }\end{array}$ & BC_OR & $\begin{array}{r}\text { Elect } \\
\text { Electro_2D }\end{array}$ & $\begin{array}{l}\text { :ronics } \\
\text { Electro_OR }\end{array}$ & $\begin{array}{l}\text { Fibers } \\
\text { Fibers }\end{array}$ & Other_2D & $\begin{array}{c}\text { Others } \\
\text { Other_Fu }\end{array}$ & Other_OR & SUM \\
\hline $\begin{array}{l}\text { From } \\
\text { Recycled }\end{array}$ & $\begin{array}{l}\text { To } \\
\text { Trade }\end{array}$ & \begin{tabular}{|l} 
Pac_F_2D \\
347245
\end{tabular} & 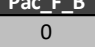 & 0 & 385403 & 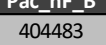 & ac_nt_-OK & 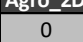 & 0 & 437692 & 0 & $\begin{array}{c}\text { D Auto_OR } \\
569744\end{array}$ & $\frac{B C D}{0}$ & 557095 & 0 & $\begin{array}{l}0 \\
0\end{array}$ & Electro_UK & $\begin{array}{l}\text { Filoers } \\
877452\end{array}$ & $\begin{array}{c}\text { Otner_LD } \\
0\end{array}$ & 441511 & $\begin{array}{c}\text { Other_OR } \\
2124745\end{array}$ & 6777231 \\
\hline Virgin & Trade & 3242534 & 0 & 0 & 3598856 & 3777017 & 3034634 & 0 & 0 & 5601212 & 0 & 12333830 & 0 & 2426489 & 0 & 0 & 2603082 & 18105842 & 0 & 505506 & 7902494 & 63131497 \\
\hline Import & Trade & 0 & 0 & 0 & 0 & 0 & 0 & 0 & 0 & 0 & 0 & 0 & 0 & 9000 & 0 & 0 & 226000 & 1035100 & 0 & 39780 & 421200 & 1731080 \\
\hline Trade & Use & 2249019 & 0 & 0 & 2496164 & 2619737 & 2519591 & 0 & 0 & 5628259 & 0 & 10280179 & 0 & 2820594 & 0 & 0 & 2948066 & 18689563 & 0 & 1132767 & 9746532 & 61130471 \\
\hline Trade & Exports & 1049987 & 0 & 0 & 1165370 & 1223062 & 583726 & 0 & 0 & 0 & 0 & 1887892 & 0 & -33878 & 0 & 0 & 0 & 0 & 0 & -212261 & 0 & 5663898 \\
\hline Trade & Source-separation & 290772 & 0 & 0 & 322725 & 338702 & 273524 & 0 & 0 & 410645 & 0 & 735504 & 0 & 205867 & 0 & 0 & 170672 & 1328831 & 0 & 66291 & 701907 & 4845439 \\
\hline Use & Source- & 2249019 & 0 & 0 & 2496164 & 2619737 & 2519590 & 0 & 0 & 4999660 & 0 & 5712424 & 0 & 1113751 & 0 & 0 & 2289721 & 15367883 & 0 & 915235 & 7890554 & 48173740 \\
\hline Use & Stock & 0 & 0 & 0 & 0 & 0 & 0 & 0 & 0 & 628598 & 0 & 4567755 & 0 & 1706843 & 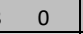 & 0 & 658344 & 3321680 & 0 & 217532 & 1855978 & 12956731 \\
\hline Source-separation & Separate collection & 1563068 & 0 & 0 & 1734834 & 1173642 & 0 & 0 & 0 & 2999796 & 0 & 0 & 0 & 779626 & 0 & 0 & 789954 & \begin{tabular}{|l|}
7683942 \\
\end{tabular} & 0 & 284638 & 2453962 & 19463463 \\
\hline Source-separation & Prod_con_w & 290772 & 0 & 0 & 322725 & 338702 & 273524 & 0 & 0 & 410645 & 0 & 735504 & 0 & 205867 & 0 & 0 & 170672 & 1328831 & 0 & 66291 & 701907 & 4845439 \\
\hline Source-separation & Residual collection & 685951 & 0 & 0 & 761330 & 1446095 & 2519590 & 0 & 0 & 1999864 & 0 & 5712424 & 0 & 334125 & 0 & 0 & 1499767 & 7683942 & 0 & 630597 & 5436592 & 28710277 \\
\hline Separate collection & Exports & 255650 & 0 & 0 & 283744 & 191957 & 0 & 0 & 0 & 11162 & 0 & 0 & 0 & 0 & 0 & 0 & 30 & 140892 & 0 & 1059 & 9131 & 893626 \\
\hline Separate collection & Plastic sorting & 1307418 & 0 & 0 & 1451090 & 981685 & 0 & 0 & 0 & 2988634 & 0 & 0 & 0 & 779626 & 0 & 0 & 789924 & 7543049 & 0 & 283579 & 2444831 & 18569837 \\
\hline Plastic sorting & Incineration & 329383 & 0 & 0 & 365579 & 330497 & 0 & 0 & 0 & 1333432 & 0 & 0 & 0 & 101829 & 0 & 0 & 418406 & \begin{tabular}{|l|}
4554294 \\
\end{tabular} & 0 & 77048 & 664256 & 8174724 \\
\hline Plastic sorting & Landfill & 5158 & 0 & 0 & 239911 & 216889 & 0 & 0 & 0 & 875065 & 0 & 0 & 0 & 54096 & 0 & 0 & 274579 & 2988755 & 0 & 50563 & 435918 & 5351934 \\
\hline Prod_con_w & Prod_con_w & 290772 & 0 & 0 & 322725 & 338702 & 273524 & 0 & 0 & 410645 & 0 & 735504 & 0 & 205867 & 0 & 0 & 170672 & $\mid 1328831$ & 0 & 66291 & 701907 & 4845439 \\
\hline Plastic sorting & Recycling & 761877 & 0 & 0 & 845599 & 434299 & 0 & 0 & 0 & 780138 & 0 & 0 & 0 & 623701 & 0 & 0 & 96939 & 0 & 0 & 155968 & 1344657 & 5043178 \\
\hline Residual collection & Incineration & 411571 & 0 & 0 & 456798 & 867657 & 1511754 & 0 & 0 & 1199918 & 0 & 5141182 & 0 & 218204 & 0 & 0 & 899860 & 4639361 & 0 & 378358 & 3261955 & 18986619 \\
\hline Residual collection & Landfill & 274380 & 0 & 0 & 304532 & 578438 & 1007836 & 0 & 0 & 799946 & 0 & 571242 & 0 & 115921 & 0 & 0 & 599907 & 3044581 & 0 & 252239 & 2174637 & 9723659 \\
\hline Residual collection & Recycling & 0 & 0 & 0 & 0 & 0 & 0 & 0 & 0 & 0 & 0 & 0 & 0 & 0 & 0 & 0 & 0 & 0 & 0 & 0 & 0 & 0 \\
\hline Recycling & Recycled raw material & 0 & 0 & 0 & 0 & 0 & 0 & 0 & 0 & 179432 & 0 & 0 & 0 & 215177 & 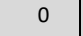 & 0 & 80460 & 0 & 0 & 375282 & 1341022 & 2191372 \\
\hline Recycling & Incineratic & 131100 & 0 & 0 & 145507 & 49821 & 0 & 0 & 0 & 362690 & 0 & 0 & 0 & 126268 & 0 & 0 & 9950 & 0 & 0 & 94170 & 811869 & 1731375 \\
\hline Recycling & Landfill & 86035 & 0 & 0 & 95489 & 32695 & 0 & 0 & 0 & 238016 & 0 & 0 & 0 & 67080 & 0 & 0 & 6530 & 0 & 0 & 61799 & 532789 & 1120431 \\
\hline Prod_con_w & Prod_con_w & 361443 & 0 & 0 & 401162 & 421022 & 356199 & 0 & 0 & 277544 & 0 & 593040 & 0 & 361965 & 0 & 0 & 220513 & 913330 & 0 & 81050 & 858172 & 4845439 \\
\hline
\end{tabular}


S5.6 Increased collection (S3)

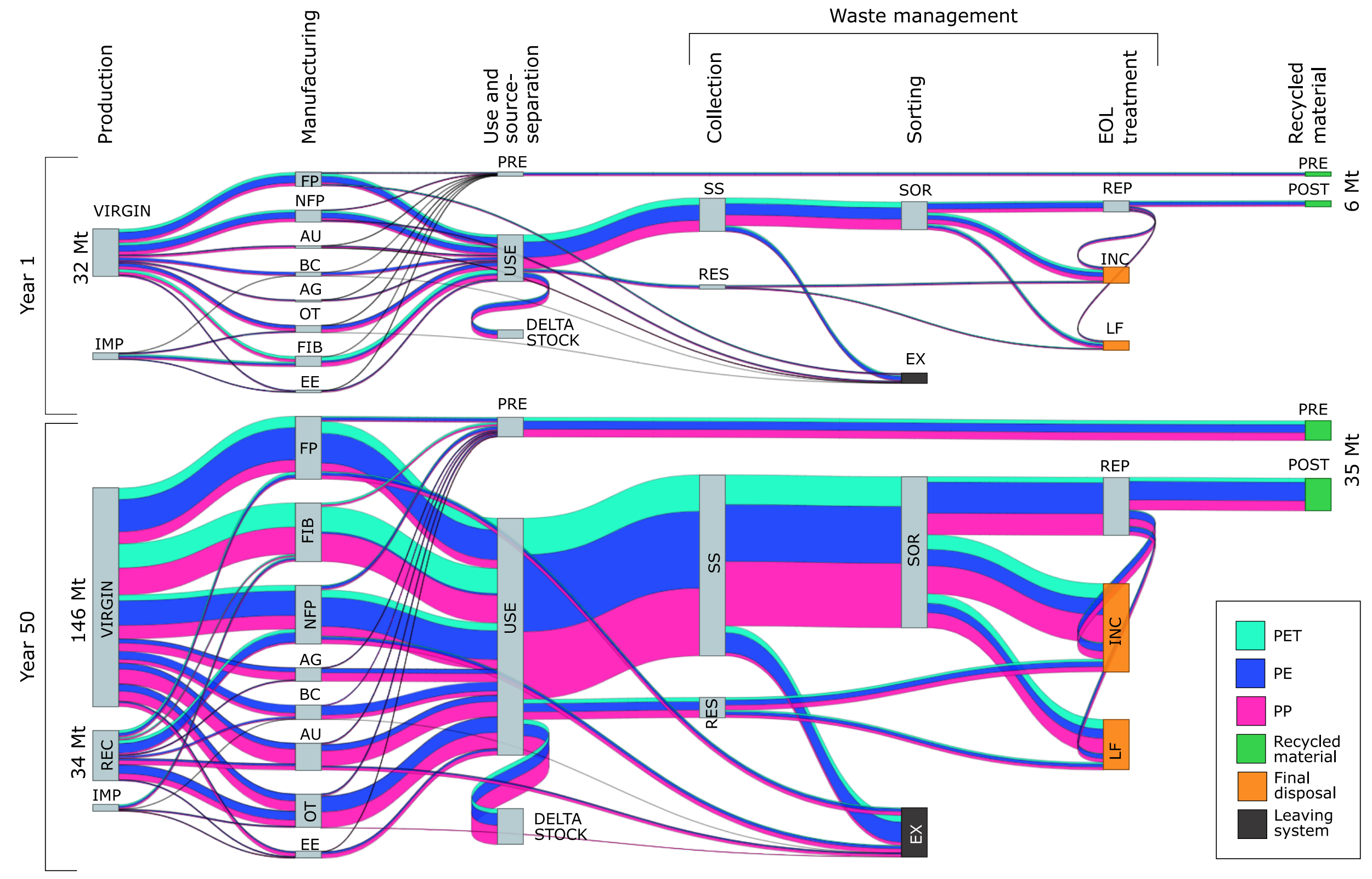

Figure S5.6 Sankey diagram for S3: Increased collection in year 1 and year 50. AG: Agriculture, AU: Automotive, BC: Building and construction, EE: Electrical and electronics, EX: Exports, FIB: Fibers, FP: Food packaging, IMP: Import, INC: Incineration, LF: Landfill, NFP: Non-food packaging, PRE: Pre-consumer, OT: Others, POST: Post-consumer, REC: Recycled plastic, REP: Reprocessing, RES: Residual waste, SOR: Sorting, SS: Source-separated waste. 


\begin{tabular}{|c|c|c|c|c|c|c|c|c|c|c|c|c|c|c|c|c|c|c|c|c|c|c|}
\hline From & To & Pac_F_2D & $\begin{array}{l}\text { Food pack. } \\
\text { Pac_F_B }\end{array}$ & Pac_F_OR & $\begin{array}{r}N \\
\text { Pac_nF_2D }\end{array}$ & $\begin{array}{l}\text { n-food pa } \\
\text { Pac_nF_B }\end{array}$ & $\begin{array}{l}\text { ck. } \\
\text { Pac_nF_OR }\end{array}$ & Agro_2L & $\begin{array}{l}\text { Agricultu } \\
\text { D Agro_P }\end{array}$ & $\begin{array}{l}\text { ure } \\
P \text { Agro_OR }\end{array}$ & $\begin{array}{r}\text { Autc } \\
\text { Auto_2 }\end{array}$ & $\begin{array}{l}\text { motive } \\
\text { Auto_OR }\end{array}$ & & $\begin{array}{r}\text { B\&C } \\
\text { BC_P }\end{array}$ & & $\begin{array}{l}\text { Elect } \\
\text { Electro_2D }\end{array}$ & $\begin{array}{l}\text { ronics } \\
\text { Electro_OR }\end{array}$ & \begin{tabular}{|l|} 
Fibers \\
Fibers
\end{tabular} & & $\begin{array}{l}\text { Others } \\
\text { Other_Fu }\end{array}$ & & SUM \\
\hline Recycled & Trade & & & & & & & & & & & & & & & & & & & & & 0 \\
\hline Virgin & Trade & 179630 & 622840 & 1245681 & 131973 & 956073 & 478036 & 0 & 6871 & 0 & 0 & 2131 & 0 & 0 & 0 & 0 & 9590 & 1800000 & 0 & 0 & 16725 & 5449551 \\
\hline Import & Trade & 0 & 0 & 0 & 0 & 0 & 0 & 0 & 0 & 0 & 0 & 0 & 0 & 0 & 0 & 0 & 4492 & 1035100 & 0 & 0 & 3752 & 1043343 \\
\hline Trade & Use & 151133 & 524031 & 1048062 & 111037 & 804398 & 402199 & 0 & 6404 & 0 & 0 & 1698 & 0 & 0 & 0 & 0 & 13515 & 2709100 & 0 & 0 & 19306 & 5790884 \\
\hline Trade & Exports & 13947 & 48359 & 96719 & 10247 & 74233 & 37116 & 0 & 0 & 0 & 0 & 312 & 0 & 0 & 0 & 0 & 0 & 0 & 0 & 0 & 0 & 280933 \\
\hline Trade & Source-separation & 14550 & 50450 & 100900 & 10690 & 77442 & 38721 & 0 & 467 & 0 & 0 & 121 & 0 & 0 & 0 & 0 & 566 & 126000 & 0 & 0 & 1171 & 421078 \\
\hline Use & Source-separation & 151133 & 524031 & 1048062 & 111037 & 804398 & 402199 & 0 & 1864 & 0 & 0 & 1286 & 0 & 0 & 0 & 0 & 1699 & 2199384 & 0 & 0 & 14253 & 5259346 \\
\hline Use & Stock & 0 & 0 & 0 & 0 & 0 & 0 & 0 & 4540 & 0 & 0 & 411 & 0 & 0 & 0 & 0 & 11816 & 509716 & 0 & 0 & 5053 & 531537 \\
\hline Source-separation & Separate collection & 136020 & 471628 & 943256 & 99933 & 723958 & 361979 & 0 & 1677 & 0 & 0 & 1158 & 0 & 0 & 0 & 0 & 1530 & 1979446 & 0 & 0 & 12828 & 4733412 \\
\hline Source-separation & Residual collection & 15113 & 52403 & 104806 & 11104 & 80440 & 40220 & 0 & 186 & 0 & 0 & 129 & 0 & 0 & 0 & 0 & 170 & 219938 & 0 & 0 & 1425 & 525935 \\
\hline Separate collection & Exports & 39807 & 138023 & 276046 & 29246 & 211868 & 105934 & 0 & 11 & 0 & 0 & 0 & 0 & 0 & 0 & 0 & 0 & 168763 & 0 & 0 & 87 & 969785 \\
\hline Separate collection & Plastic sorting & 96213 & 333605 & 667209 & 70687 & 512090 & 256045 & 0 & 1666 & 0 & 0 & 1158 & 0 & 0 & 0 & 0 & 1529 & 1810683 & 0 & 0 & 12741 & 3763626 \\
\hline Plastic sorting & Incineration & 25560 & 42299 & 310189 & 18779 & 64929 & 119037 & 0 & 523 & 0 & 0 & 1158 & 0 & 0 & 0 & 0 & 268 & 1093242 & 0 & 0 & 3769 & 1679753 \\
\hline Plastic sorting & Landfill & 16774 & 27758 & 203562 & 12324 & 42610 & 78118 & 0 & 343 & 0 & 0 & 0 & 0 & 0 & 0 & 0 & 176 & 717440 & 0 & 0 & 2474 & 1101578 \\
\hline Prod_con_w & Prod_con_w & 14550 & 50450 & 100900 & 10690 & 77442 & 38721 & 0 & 467 & 0 & 0 & 121 & 0 & 0 & 0 & 0 & 566 & 126000 & 0 & 0 & 1171 & 421078 \\
\hline Plastic sorting & Recycling & 53879 & 263548 & 153458 & 39585 & 404551 & 58890 & 0 & 800 & 0 & 0 & 0 & 0 & 0 & 0 & 0 & 1086 & 0 & 0 & 0 & 6498 & 982295 \\
\hline Residual collection & Incineration & 9125 & 31640 & 63279 & 6704 & 48567 & 24284 & 0 & 113 & 0 & 0 & 129 & 0 & 0 & 0 & 0 & 103 & 132793 & 0 & 0 & 861 & 317596 \\
\hline Residual collection & Landfill & 5988 & 20763 & 41527 & 4400 & 31872 & 15936 & 0 & 74 & 0 & 0 & 0 & 0 & 0 & 0 & 0 & 67 & 87145 & 0 & 0 & 565 & 208338 \\
\hline Residual collection & Recycling & 0 & 0 & 0 & 0 & 0 & 0 & 0 & 0 & 0 & 0 & 0 & 0 & 0 & 0 & 0 & 0 & 0 & 0 & 0 & 0 & 0 \\
\hline Recycling & Landfill & 5337 & 21929 & 15809 & 3921 & 33662 & 6067 & 0 & 247 & 0 & 0 & 0 & 0 & 0 & 0 & 0 & 129 & 0 & 0 & 0 & 2575 & 89676 \\
\hline Prod_con_w & Prod_con_w & 14550 & 50450 & 100900 & 10690 & 77442 & 38721 & 0 & 467 & 0 & 0 & 121 & 0 & 0 & 0 & 0 & 566 & 126000 & 0 & 0 & 1171 & 421078 \\
\hline
\end{tabular}

Table S5.32 Detailed PET flow values [ton] in year 50 in S3: Increased collection. Prod_con_w: Pre-consumer waste. Flow abbreviations are provided in Table S1.1 and on page 53.

\begin{tabular}{|c|c|c|c|c|c|c|c|c|c|c|c|c|c|c|c|c|c|c|c|c|c|c|}
\hline \multirow[b]{2}{*}{ From } & \multirow[b]{2}{*}{ To } & \multicolumn{3}{|c|}{ Food pack. } & \multicolumn{3}{|c|}{ Non-food pack. } & \multicolumn{3}{|c|}{ Agriculture } & \multicolumn{2}{|c|}{ Automotive } & \multicolumn{3}{|c|}{$B \& C$} & \multirow{2}{*}{\multicolumn{2}{|c|}{$\begin{array}{c}\text { Electronics } \\
\text { ctro_2D Electro_OR }\end{array}$}} & \multirow{2}{*}{\begin{tabular}{|l|} 
Fibers \\
Fibers \\
\end{tabular}} & \multirow{2}{*}{\multicolumn{3}{|c|}{$\begin{array}{c}\text { Others } \\
\text { Other_2D Other_Fu Other_OR }\end{array}$}} & \multirow{2}{*}{ SUM } \\
\hline & & Pac_F_2D & Pac_F_B & Pac_F_OR & Pac_nF_2 & D Pac_nF_B & Pac_nF_OR & Agro_2D & D Agro_P & Agro_of & Auto_2D & Auto_OR & BC_2D & BC_P & BC_OR & & & & & & & \\
\hline Recycled & Trade & 81633 & 408091 & 1358722 & 59975 & 784114 & 1361629 & 0 & 7708 & 0 & 0 & 681 & 0 & 0 & 0 & 0 & 22843 & 956324 & 0 & 0 & 6569 & 5048289 \\
\hline Virgin & Trade & 506025 & 1536260 & 5443880 & 371774 & 2200506 & 1248905 & 0 & 60565 & 0 & 0 & 20493 & 0 & 0 & 0 & 0 & 34604 & 16128640 & 0 & 0 & 82676 & 27634328 \\
\hline Import & Trade & 0 & 0 & 0 & 0 & 0 & 0 & 0 & 0 & 0 & 0 & 0 & 0 & 0 & 0 & 0 & 4492 & 1035100 & 0 & 0 & 3752 & 1043343 \\
\hline Trade & Use & 494431 & 1635893 & 5723416 & 363255 & 2511130 & 2196390 & 0 & 63630 & 0 & 0 & 16868 & 0 & 0 & 0 & 0 & 58549 & $\mid 16924117$ & 0 & 0 & 86749 & 30074428 \\
\hline Trade & Exports & 45628 & 150966 & 528176 & 33522 & 231735 & 202690 & 0 & 0 & 0 & 0 & 3099 & 0 & 0 & 0 & 0 & 0 & 0 & 0 & 0 & 0 & 1195816 \\
\hline Trade & Source-separation & 47600 & 157492 & 551011 & 34972 & 241754 & 211453 & 0 & 4643 & 0 & 0 & 1207 & 0 & 0 & 0 & 0 & 3389 & \begin{tabular}{|l|l|}
1195947 \\
\end{tabular} & 0 & 0 & 6247 & 2455716 \\
\hline Use & Source-separation & 494431 & 1635893 & 5723416 & 363255 & 2511130 & 2196390 & 0 & 56523 & 0 & 0 & 9373 & 0 & 0 & 0 & 0 & 45475 & 13934605 & 0 & 0 & 70231 & 27040722 \\
\hline Use & Stock & 0 & 0 & 0 & 0 & 0 & 0 & 0 & 7107 & 0 & 0 & 7495 & 0 & 0 & 0 & 0 & 13074 & 2989512 & 0 & 0 & 16519 & 3033706 \\
\hline Source-separation & Prod_con_w & 47600 & 157492 & 551011 & 34972 & 241754 & 211453 & 0 & 4643 & 0 & 0 & 1207 & 0 & 0 & 0 & 0 & 3389 & $\mid 1195947$ & 0 & 0 & 6247 & 2455716 \\
\hline Source-separation & Residual collection & 49443 & 163589 & 572342 & 36326 & 251113 & 219639 & 0 & 5652 & 0 & 0 & 937 & 0 & 0 & 0 & 0 & 4548 & $\mid 1393461$ & 0 & 0 & 7023 & 2704072 \\
\hline Separate collection & Exports & 130227 & 430874 & 1507476 & 95677 & 661400 & 578502 & 0 & 344 & 0 & 0 & 0 & 0 & 0 & 0 & 0 & 3 & 1069229 & 0 & 0 & 427 & 4474157 \\
\hline Separate collection & Plastic sorting & 314761 & 1041430 & 3643598 & 231253 & 1598617 & 1398249 & 0 & 50527 & 0 & 0 & 8436 & 0 & 0 & 0 & 0 & 40925 & 11471916 & 0 & 0 & 62781 & 19862492 \\
\hline Plastic sorting & Incineration & 83619 & 132045 & 1693929 & 61435 & 202693 & 650054 & 0 & 15864 & 0 & 0 & 8436 & 0 & 0 & 0 & 0 & 7166 & \begin{tabular}{|l|}
6926440 \\
\end{tabular} & 0 & 0 & 18574 & 9800254 \\
\hline Plastic sorting & Landfill & 54875 & 86655 & 1111641 & 40317 & 133017 & 426598 & 0 & 10411 & 0 & 0 & 0 & 0 & 0 & 0 & 0 & 4703 & $\mid 4545476$ & 0 & 0 & 12189 & 6425881 \\
\hline Prod_con_w & Prod_con_w & 47600 & 157492 & 551011 & 34972 & 241754 & 211453 & 0 & 4643 & 0 & 0 & 1207 & 0 & 0 & 0 & 0 & 3389 & $\mid 1195947$ & 0 & 0 & 6247 & 2455716 \\
\hline Plastic sorting & Recycling & 176266 & 822730 & 838028 & 129502 & 1262907 & 321597 & 0 & 24253 & 0 & 0 & 0 & 0 & 0 & 0 & 0 & 29057 & 0 & 0 & 0 & 32018 & 3636357 \\
\hline Residual collection & Incineration & 29852 & 98771 & 345565 & 21932 & 151615 & 132612 & 0 & 3413 & 0 & 0 & 937 & 0 & 0 & 0 & 0 & 2746 & 841335 & 0 & 0 & 4240 & 1633019 \\
\hline Residual collection & Landfill & 19591 & 64818 & 226777 & 14393 & 99498 & 87027 & 0 & 2240 & 0 & 0 & 0 & 0 & 0 & 0 & 0 & 1802 & 552126 & 0 & 0 & 2783 & 1071053 \\
\hline Residual collection & Recycling & 0 & 0 & 0 & 0 & 0 & 0 & 0 & 0 & 0 & 0 & 0 & 0 & 0 & 0 & 0 & 0 & 0 & 0 & 0 & 0 & 0 \\
\hline Recycling & Incineration & 26606 & 104316 & 131555 & 19547 & 160127 & 50485 & 0 & 11422 & 0 & 0 & 0 & 0 & 0 & 0 & 0 & 5263 & 0 & 0 & 0 & 19332 & 528653 \\
\hline Recycling & Landfill & 17460 & 68457 & 86333 & 12828 & 105083 & 33131 & 0 & 7496 & 0 & 0 & 0 & 0 & 0 & 0 & 0 & 3454 & 0 & 0 & 0 & 12686 & 346928 \\
\hline Prod_con_w & Prod_con_w & 84855 & 294223 & 588447 & 62343 & 451639 & 225819 & 0 & 2725 & 0 & 0 & 708 & 0 & 0 & 0 & 0 & 3300 & 734828 & 0 & 0 & 6828 & 2455716 \\
\hline
\end{tabular}




\begin{tabular}{|c|c|c|c|c|c|c|c|c|c|c|c|c|c|c|c|c|c|c|c|c|c|c|}
\hline From & To & \multicolumn{3}{|c|}{ Food pack. } & \multicolumn{3}{|c|}{ Non-food pack. } & \multicolumn{3}{|c|}{ Agriculture } & \multicolumn{2}{|c|}{ Automotive } & \multicolumn{3}{|c|}{$B \& C$} & \multicolumn{2}{|c|}{ Electronics } & \multirow[t]{2}{*}{$\begin{array}{l}\text { Fibers } \\
\text { Fibers }\end{array}$} & \multicolumn{3}{|c|}{ Others } & SUM \\
\hline Recycled & Trade & & & & & & & & & & & & & & & & & & & & & 0 \\
\hline Virgin & Trade & 4497128 & 397936 & 161611 & 2407793 & 1760749 & 118994 & 365360 & 77688 & 60790 & 0 & 517785 & 548048 & 1201236 & 0 & 0 & 421489 & 0 & 0 & 255741 & 1742712 & 14535062 \\
\hline Import & Trade & 0 & 0 & 0 & 0 & 0 & 0 & 0 & 0 & 0 & 0 & 0 & 6579 & 14421 & 0 & 0 & 197000 & 1035100 & 0 & 57378 & 390998 & 1701477 \\
\hline Trade & Use & \begin{tabular}{|l|}
3797268 \\
\end{tabular} & 336008 & 136460 & 2033083 & 1486734 & 100476 & \begin{tabular}{|l}
340516 \\
\end{tabular} & 72405 & 56656 & 0 & 412484 & 516812 & 1132772 & 0 & 0 & 593621 & 1035100 & 0 & 295217 & 2011721 & 14357335 \\
\hline Trade & Exports & 335593 & 29696 & 12060 & 179679 & 131394 & 8880 & 0 & 0 & 0 & 0 & 75787 & 0 & 0 & 0 & 0 & 0 & 0 & 0 & 0 & 0 & 773088 \\
\hline Trade & Source-separation & 364267 & 32233 & 13090 & 195031 & 142621 & 9639 & 24844 & 5283 & 4134 & 0 & 29514 & 37815 & 82885 & 0 & 0 & 24868 & 0 & 0 & 17902 & 121990 & 1106116 \\
\hline Use & Source-separation & \begin{tabular}{|l|}
3797267 \\
\end{tabular} & 336008 & 136460 & 2033083 & 1486734 & 100476 & 303062 & 65499 & 49178 & 0 & 177242 & 20233 & 45036 & 0 & 0 & 304765 & 840346 & 0 & 237430 & 1679990 & 11612809 \\
\hline Use & Stock & 1 & 0 & 0 & 1 & 0 & 0 & 37454 & 6906 & 7479 & 0 & 235242 & 496579 & 1087736 & 0 & 0 & 288856 & 194754 & 0 & 57787 & 331731 & 2744526 \\
\hline Source-separation & Separate collection & 3417540 & 302407 & 122814 & 1829774 & 1338061 & 90428 & 272755 & 58949 & 44260 & 0 & 159518 & 18210 & 40532 & 0 & 0 & 274289 & 756312 & 0 & 213687 & 1511991 & 10451528 \\
\hline Source-separation & Residual collection & 379727 & 33601 & 13646 & 203308 & 148673 & 10048 & 30306 & 6550 & 4918 & 0 & 17724 & 2023 & 4504 & 0 & 0 & 30477 & 84035 & 0 & 23743 & 167999 & 1161281 \\
\hline Separate collection & Exports & \begin{tabular}{|l|}
1296178 \\
\end{tabular} & 114695 & 46580 & 693983 & 507489 & 34297 & 2353 & 509 & 382 & 0 & 0 & 0 & 0 & 0 & 0 & 24 & 0 & 0 & 1844 & 13046 & 2711380 \\
\hline Separate collection & Plastic sorting & 2121362 & 187712 & 76234 & 1135792 & 830571 & 56131 & 270402 & 58441 & 43878 & 0 & 159518 & 18210 & 40532 & 0 & 0 & 274265 & 756312 & 0 & 211843 & 1498944 & 7740147 \\
\hline Plastic sorting & Incineration & 563562 & 32867 & 45568 & 301735 & 145428 & 33552 & 93059 & 22582 & 19869 & 0 & 39880 & 3297 & 6537 & 0 & 0 & 125851 & 756312 & 0 & 67790 & 479662 & 2737551 \\
\hline Plastic sorting & Landfill & 369837 & 21569 & 29904 & 198013 & 95437 & 22018 & 61070 & 14820 & 13039 & 0 & 0 & 1256 & 3596 & 0 & 0 & 82590 & 0 & 0 & 44487 & 314778 & 1272415 \\
\hline Prod_con_w & Prod_con_w & 364267 & 32233 & 13090 & 195031 & 142621 & 9639 & 24844 & 5283 & 4134 & 0 & 29514 & 37815 & 82885 & 0 & 0 & 24868 & 0 & 0 & 17902 & 121990 & 1106116 \\
\hline Plastic sorting & Recycling & 1187963 & 133276 & 762 & 636043 & 589706 & 561 & 116273 & 21039 & 10970 & 0 & 119639 & 13658 & 30399 & 0 & 0 & 65824 & 0 & 0 & 99566 & 704504 & 3730181 \\
\hline Residual collection & Incineration & 227836 & 20160 & 8188 & 121985 & 89204 & 6029 & 18184 & 3930 & 2951 & 0 & 15952 & 1465 & 2906 & 0 & 0 & 18286 & 84035 & 0 & 14246 & 100799 & 736154 \\
\hline Residual collection & Landfill & 151891 & 13440 & 5458 & 81323 & 59469 & 4019 & 12122 & 2620 & 1967 & 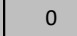 & 1772 & 558 & 1598 & 0 & 0 & 12191 & 0 & 0 & 9497 & 67200 & 425127 \\
\hline Residual collection & Recycling & 0 & 0 & 0 & 0 & 0 & 0 & 0 & 0 & 0 & 0 & 0 & 0 & 0 & 0 & 0 & 0 & 0 & 0 & 0 & 0 & 0 \\
\hline Recycling & Recycled raw material & 0 & 0 & 0 & 642072 & 314497 & 0 & 12790 & 4628 & 2413 & 0 & 84943 & 4848 & 10792 & 0 & 0 & 54634 & 0 & 0 & 236190 & 724209 & 2092016 \\
\hline Recycling & Landfill & 145918 & 6865 & 79 & 78125 & 30375 & 58 & 35935 & 6502 & 3390 & 0 & 0 & 1093 & 3128 & 0 & 0 & 4434 & 0 & 0 & 39451 & 279143 & 634495 \\
\hline Prod_con_w & Prod_con_w & 364267 & 32233 & 13090 & 195031 & 142621 & 9639 & 24844 & 5283 & 4134 & 0 & 29514 & 37815 & 82885 & 0 & 0 & 24868 & 0 & 0 & 17902 & 121990 & 1106116 \\
\hline
\end{tabular}

Table S5.34 Detailed PE flow values [ton] in year 50 in S3: Increased collection. Prod_con_w: Pre-consumer waste. Flow abbreviations are provided in Table S1.1 and on page 53.

\begin{tabular}{|c|c|c|c|c|c|c|c|c|c|c|c|c|c|c|c|c|c|c|c|c|c|c|}
\hline \multirow[b]{2}{*}{ From } & \multirow[b]{2}{*}{ To } & \multicolumn{3}{|c|}{ Food pack. } & \multicolumn{3}{|c|}{ Non-food pack. } & \multicolumn{3}{|c|}{ Agriculture } & \multirow{2}{*}{\multicolumn{2}{|c|}{$\begin{array}{l}\text { Automotive } \\
\text { ato 2D Auto OR }\end{array}$}} & \multicolumn{3}{|c|}{$B \& C$} & \multirow{2}{*}{\multicolumn{2}{|c|}{$\begin{array}{l}\text { Electronics } \\
\text { ro 2D Electro OR }\end{array}$}} & \multirow{2}{*}{$\begin{array}{l}\text { Fibers } \\
\text { Fibers }\end{array}$} & \multirow{2}{*}{\multicolumn{3}{|c|}{$\begin{array}{c}\text { Others } \\
\text { Other_2D Other_Fu }\end{array}$}} & \multirow{2}{*}{ SUM } \\
\hline & & Pac_F_2D & Pac_F_B & Pac_F_OR & Pac_nF_2D & Pac_nF_B & Pac_nF_OF & gro_2D & Agro_P & Agro_OR & & & BC_2D & BC_P & BC_OR & & & & & & & \\
\hline Recycled & Trade & 1769076 & 156540 & 63574 & 3788394 & 2679576 & 46810 & 196265 & 52575 & 34703 & 0 & 1183823 & 361216 & 791854 & 0 & 0 & 324199 & 0 & 0 & 1276154 & 4726969 & 17451728 \\
\hline Virgin & Trade & 18627664 & 2458112 & 669411 & 7132160 & 8889474 & 492889 & 1992475 & 412825 & 329469 & 0 & 3961030 & 1701732 & 3729807 & 0 & 0 & 873725 & 0 & 0 & 88445 & 4571911 & 55931129 \\
\hline Import & Trade & 0 & 0 & 0 & 0 & 0 & 0 & 0 & 0 & 0 & 0 & 0 & 6579 & 14421 & 0 & 0 & 197000 & 1035100 & 0 & 57378 & 390998 & 1701477 \\
\hline Trade & Exports & 1522083 & 195115 & 54698 & 4934 & 863327 & 40274 & 0 & 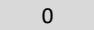 & 0 & 0 & 753041 & 0 & 0 & 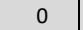 & 0 & 0 & 0 & 0 & 0 & 0 & 4243473 \\
\hline Trade & Source-separation & 1652136 & 211787 & 59372 & 884565 & 937093 & 43716 & 148834 & 31647 & 24764 & 0 & 293257 & 142343 & 311995 & 0 & 0 & 70678 & 0 & 0 & 95522 & 650922 & 5558629 \\
\hline Use & Source-separation & 17222521 & 2207750 & 618915 & 9221056 & 9768630 & 455709 & 1859597 & 395413 & 309408 & 0 & 2277459 & 761526 & 1669520 & 0 & 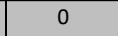 & 1155422 & 1035100 & 0 & 1073876 & 7317794 & 57349694 \\
\hline Use & Stock & 0 & 0 & 0 & 0 & 0 & 0 & 180308 & 38340 & 30001 & 0 & 1821097 & 1165658 & 2554568 & 0 & 0 & 168825 & 0 & 0 & 252578 & 1721163 & 7932538 \\
\hline Source-separation & Separate collection & 15500269 & 1986975 & 557024 & 8298950 & 8791767 & 410138 & 1673637 & 355872 & 278467 & 0 & 2049713 & 685373 & 1502568 & 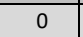 & 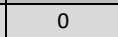 & 1039880 & \begin{tabular}{|l|}
931590 \\
\end{tabular} & 0 & 966489 & 6586014 & 51614725 \\
\hline Source-separation & Residual collection & 1722252 & 220775 & 61892 & 922106 & 976863 & 45571 & 185960 & 39541 & 30941 & 0 & 227746 & 76153 & 166952 & 0 & 0 & 115542 & 103510 & 0 & 107388 & 731779 & 5734969 \\
\hline Separate collection & Exports & 5878823 & 753605 & 211264 & 3147562 & 3334474 & 155554 & 14441 & 3071 & 2403 & 0 & 0 & 0 & 0 & 0 & 0 & 92 & 0 & 0 & 8339 & 56827 & 13566455 \\
\hline Separate collection & Plastic sorting & 9621446 & 1233370 & 345760 & 5151388 & 5457293 & 254584 & 1659196 & 352801 & 276064 & 0 & 2049713 & 685373 & 1502567 & 0 & 0 & 1039788 & 931590 & 0 & 958149 & 6529187 & 38048270 \\
\hline Plastic sorting & Incineration & 2556037 & 215956 & 206673 & 1368520 & 955541 & 152174 & 571014 & 136328 & 125010 & 0 & 512428 & 124076 & 242350 & 0 & 0 & 477125 & \begin{tabular}{|l|}
931590 \\
\end{tabular} & 0 & 306608 & 2089340 & 10970770 \\
\hline Plastic sorting & Landfill & 1677399 & 141721 & 135629 & 898091 & 627074 & 99864 & 374728 & 89465 & 82038 & 0 & 0 & 47267 & 133292 & 0 & 0 & 313114 & 0 & 0 & 201211 & 1371129 & 6192023 \\
\hline Prod_con_w & Prod_con_w & 1652136 & 211787 & 59372 & 884565 & 937093 & 43716 & 148834 & 31647 & 24764 & 0 & 293257 & 142343 & 311995 & 0 & 0 & 70678 & 0 & 0 & 95522 & 650922 & 5558629 \\
\hline Plastic sorting & Recycling & 5388010 & 875693 & 3458 & 2884777 & 3874678 & 2546 & 713454 & 127008 & 69016 & 0 & 1537285 & 514030 & 1126925 & 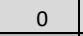 & O & 249549 & 0 & 0 & 450330 & 3068718 & 20885477 \\
\hline Residual collection & Incineration & 1033351 & 132465 & 37135 & 553263 & 586118 & 27343 & 111576 & 23725 & 18564 & 0 & 204971 & 55145 & 107711 & 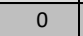 & 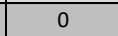 & 69325 & 103510 & 0 & 64433 & 439068 & 3567703 \\
\hline Residual collection & Landfill & 688901 & 88310 & 24757 & 368842 & 390745 & 18228 & 74384 & 15817 & 12376 & 0 & 22775 & 21008 & 59241 & 0 & 0 & 46217 & 0 & 0 & 42955 & 292712 & 2167267 \\
\hline Residual collection & Recycling & 0 & 0 & 0 & 0 & 0 & 0 & 0 & o & 0 & 0 & 0 & 0 & 0 & 0 & 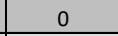 & 0 & 0 & 0 & 0 & 0 & 0 \\
\hline Recycling & Recycled raw material & 0 & 0 & 0 & 2932591 & 2066411 & 0 & 78480 & 27942 & 15184 & 0 & 1091472 & 182481 & 400059 & 0 & 0 & 207126 & 0 & 0 & 1231241 & 4276263 & 12509250 \\
\hline Recycling & Landfill & 661810 & 45106 & 356 & 354338 & 199582 & 262 & 220498 & 39253 & 21330 & 0 & 0 & 41122 & 115964 & 0 & 0 & 16809 & 0 & 0 & 178433 & 1215907 & 3110771 \\
\hline Prod_con_w & Prod_con_w & 1830574 & 161982 & 65784 & 980102 & 716720 & 48437 & 124852 & 26548 & 20773 & 0 & 148317 & 190036 & 416528 & 0 & 0 & 124970 & 0 & 0 & 89963 & 613043 & 5558629 \\
\hline
\end{tabular}




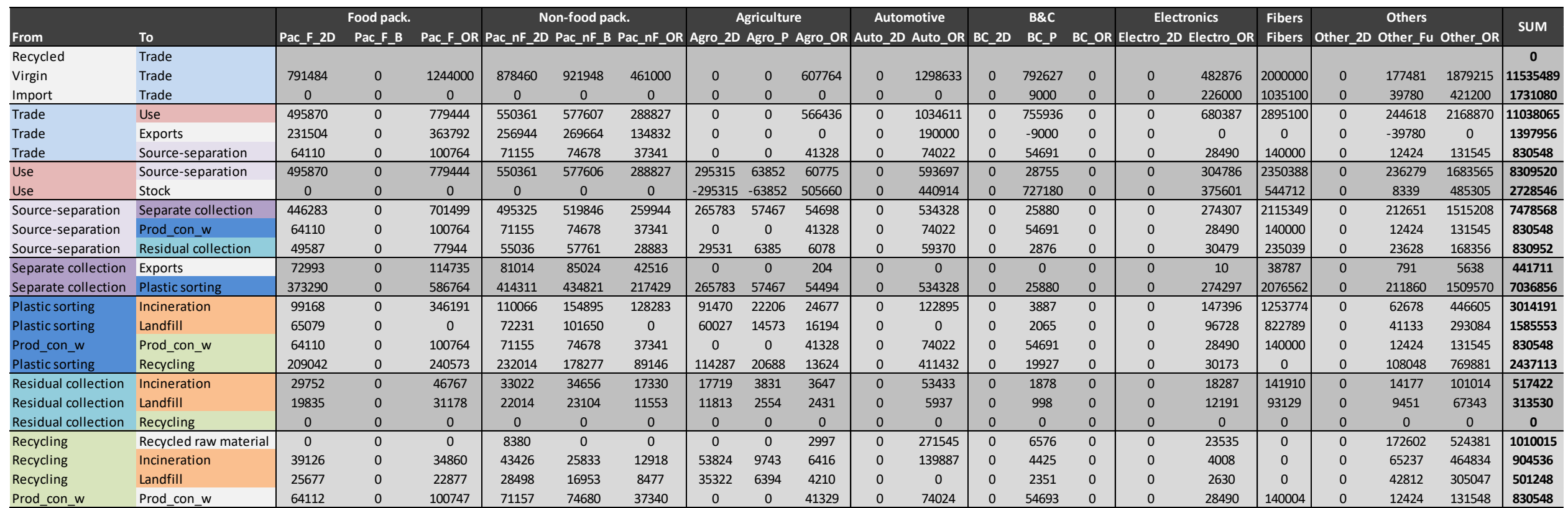

Table S5.36 Detailed PP flow values [ton] in year 50 in S3: Increased collection. Prod_con_w: Pre-consumer waste. Flow abbreviations are provided in Table S1.1 and on page 53.

\begin{tabular}{|c|c|c|c|c|c|c|c|c|c|c|c|c|c|c|c|c|c|c|c|c|c|c|}
\hline \multirow{2}{*}{ From } & \multirow[b]{2}{*}{ To } & \multicolumn{3}{|c|}{ Food pack. } & \multicolumn{3}{|c|}{ Non-food pack. } & \multicolumn{3}{|c|}{ Agriculture } & \multirow{2}{*}{\multicolumn{2}{|c|}{\begin{tabular}{|c|} 
Automotive \\
Auto 2D Auto OR
\end{tabular}}} & \multicolumn{3}{|c|}{$B \& C$} & \multicolumn{2}{|c|}{ Electronics } & \multirow{2}{*}{$\begin{array}{l}\text { Fibers } \\
\text { Fibers }\end{array}$} & \multirow{2}{*}{\multicolumn{2}{|c|}{$\begin{array}{c}\text { Others } \\
\text { Other 2D Other Fu }\end{array}$}} & \multirow{2}{*}{ Other_OR } & \multirow{2}{*}{ SUM } \\
\hline & & Pac_F_2D & Pac_F_B & Pac_F_OR & Pac_nF_2 & D Pac_nF_B & Pac_nF_OR & gro_2D & Agro_ & Agro_OR & & & BC_2D & BC_P & BC_OR & Electro_2D & Electro_OR & & & Other_Fu & & \\
\hline Recycled & Trade & 383623 & 0 & 602837 & 425780 & 446858 & 223429 & 0 & 0 & 482344 & 0 & 2933638 & 0 & 575067 & 0 & 0 & 341449 & 837734 & 0 & 820638 & 3273838 & 11347237 \\
\hline Virgin & Trade & 3206155 & 0 & 4782791 & 3558480 & 3734642 & 1772370 & 0 & 0 & 5556560 & 0 & 9969936 & 0 & 2408517 & 0 & 0 & 2551288 & $|18145560|$ & 0 & 126379 & 6753401 & 62566078 \\
\hline Import & Trade & 0 & 0 & 0 & 0 & 0 & 0 & 0 & 0 & 0 & 0 & 0 & 0 & 9000 & 0 & 0 & 226000 & $\mid$\begin{tabular}{|l|}
$\mid 1035100$ \\
\end{tabular} & 0 & 39780 & 421200 & 1731080 \\
\hline Trade & Exports & 1049987 & 0 & 1574958 & 1165370 & 1223062 & 583726 & 0 & 0 & 0 & 促 & 1887892 & 0 & -33878 & 0 & 0 & 0 & 0 & 0 & -212261 & 0 & 7238857 \\
\hline Trade & Source-separation & 290772 & 0 & 436236 & 322725 & 338702 & 161660 & 0 & 0 & 410645 & 0 & 735504 & 0 & 205867 & 0 & 0 & 170672 & 1328831 & 0 & 66291 & 701907 & 5169811 \\
\hline Use & Source-separation & 2249019 & 0 & 3374433 & 2496164 & 2619737 & 1250414 & 0 & 0 & 4999660 & 0 & 5712424 & 0 & 1113751 & 0 & 0 & 2289721 & 15367883 & 0 & 915235 & 7890554 & 50278996 \\
\hline Use & Stock & 0 & 0 & 0 & 0 & 0 & 0 & 0 & 0 & 628598 & 0 & 4567755 & 0 & 1706843 & 0 & 0 & 658344 & \begin{tabular}{|l|}
3321680 \\
\end{tabular} & 0 & 217532 & 1855978 & 12956731 \\
\hline Source-separation & Separate collection & 2024117 & 0 & 3036990 & 2246548 & 2357763 & 1125372 & 0 & 0 & 4499694 & 0 & 5141182 & 0 & 1002376 & 0 & 0 & 2060749 & 13831095 & 0 & 823711 & 7101499 & 45251097 \\
\hline Source-separation & Residual collection & 224902 & 0 & 337443 & 249616 & 261974 & 125041 & 0 & 0 & 499966 & 0 & 571242 & 0 & 111375 & 0 & 0 & 228972 & 1536788 & 0 & 91523 & 789055 & 5027900 \\
\hline Separate collection & Exports & 331058 & 0 & 496720 & 367438 & 385628 & 184062 & 0 & 0 & 16743 & 0 & 0 & 0 & 0 & 0 & 0 & 78 & 253606 & 0 & 3065 & 26424 & 2064824 \\
\hline Separate collection & Plastic sorting & 1693059 & 0 & 2540270 & 1879110 & 1972135 & 941310 & 0 & 0 & 4482951 & 0 & 5141182 & 0 & 1002376 & 0 & 0 & 2060671 & 13577489 & 0 & 820646 & 7075075 & 43186273 \\
\hline Plastic sorting & Incineration & 449779 & 0 & 1498759 & 499205 & 702527 & 555373 & 0 & 0 & 2030016 & 0 & 1182472 & 0 & 150561 & 0 & 0 & 1107319 & \begin{tabular}{|l|}
8197729 \\
\end{tabular} & 0 & 242787 & 2093154 & 18709680 \\
\hline Plastic sorting & Landfill & 295167 & 0 & 0 & 327603 & 461033 & 0 & 0 & 0 & 1332198 & 0 & 0 & 0 & 79986 & 0 & 0 & 726678 & $\mid 5379760$ & 0 & 159329 & 1373632 & 10135386 \\
\hline Prod_con_w & Prod_con_w & 290772 & 0 & 436236 & 322725 & 338702 & 161660 & 0 & 0 & 410645 & 0 & 735504 & 0 & 205867 & 0 & 0 & 170672 & 1328831 & 0 & 66291 & 701907 & 5169811 \\
\hline Plastic sorting & Recycling & 948113 & 0 & 1041511 & 1052301 & 808575 & 385937 & 0 & 0 & 1120738 & 0 & 3958710 & 0 & 771830 & 0 & 0 & 226674 & 0 & 0 & 418530 & 3608288 & 14341206 \\
\hline Residual collection & Incineration & 134941 & 0 & 202466 & 149770 & 157184 & 75025 & 0 & 0 & 299980 & 0 & 514118 & 0 & 72735 & 0 & 0 & 137383 & 927872 & 0 & 54914 & 473433 & 3199821 \\
\hline Residual collection & Landfill & 89961 & 0 & 134977 & 99847 & 104789 & 50017 & 0 & 0 & 199986 & 0 & 57124 & 0 & 38640 & 0 & 0 & 91589 & 608916 & 0 & 36609 & 315622 & 1828078 \\
\hline Residual collection & Recycling & 0 & 0 & 0 & 0 & 0 & 0 & 0 & 0 & 0 & 0 & 0 & 0 & 0 & 0 & 0 & 0 & 0 & 0 & 0 & 0 & 0 \\
\hline Recycling & Recycled raw material & 0 & 0 & 0 & 0 & 0 & 0 & 0 & 0 & 246562 & 0 & 2612748 & 0 & 254704 & 0 & 0 & 176806 & 0 & 0 & 769916 & 2564451 & 6625187 \\
\hline Recycling & Landfill & 116457 & 0 & 99042 & 129254 & 76891 & 36700 & 0 & 0 & 346371 & 0 & 0 & 0 & 91044 & 0 & 0 & 19759 & 0 & 0 & 165832 & 1429699 & 2511051 \\
\hline Prod_con_w & Prod_con_w & 399069 & 0 & 627109 & 442923 & 464850 & 232425 & 0 & 0 & 257256 & 0 & 460768 & 0 & 340439 & 0 & 0 & 177341 & 871463 & 0 & 77334 & 818833 & 5169811 \\
\hline
\end{tabular}


S5.7 State-of-the-art EOL technology (S4)

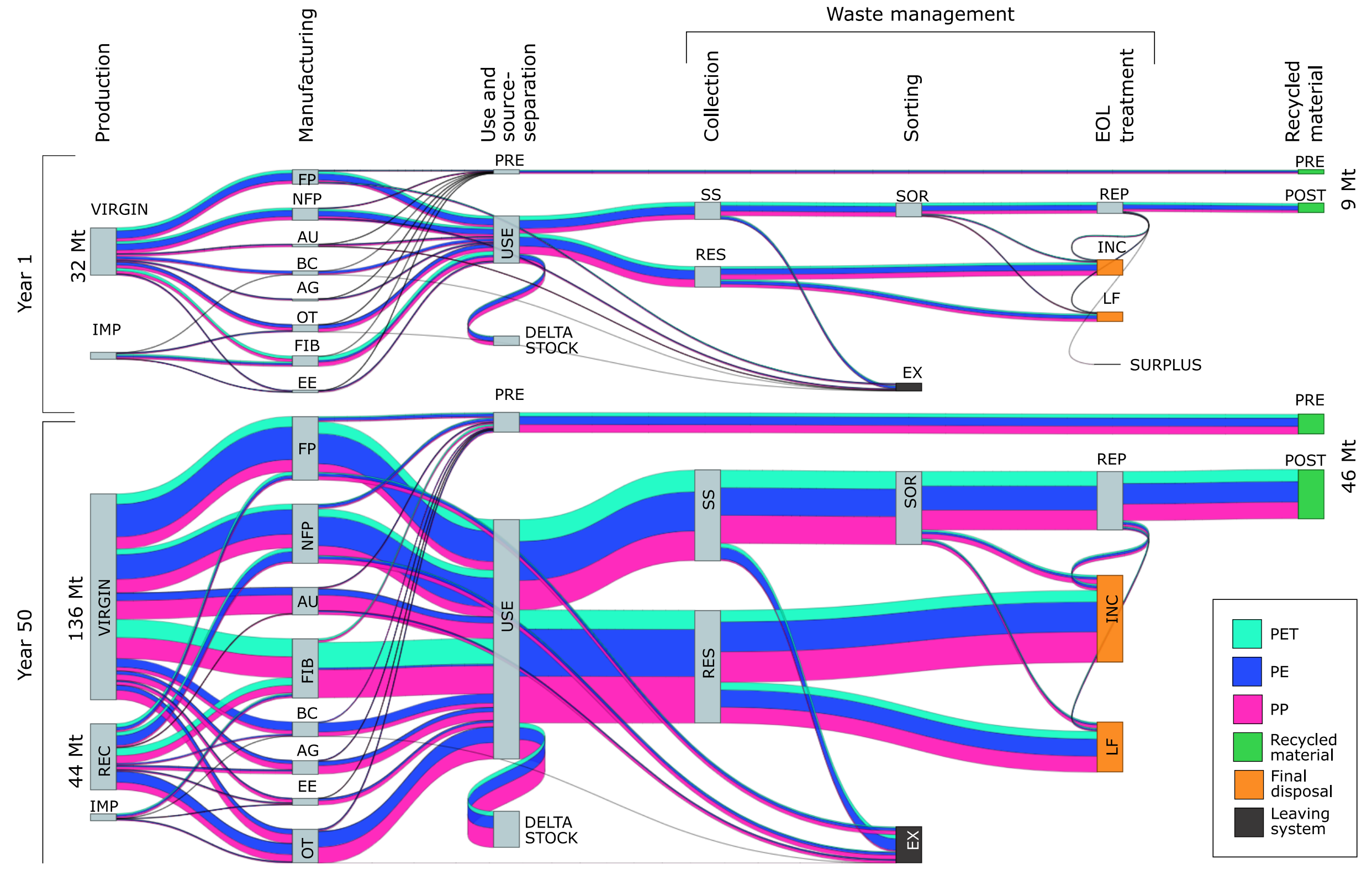

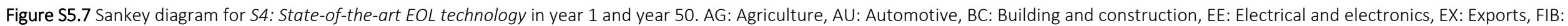

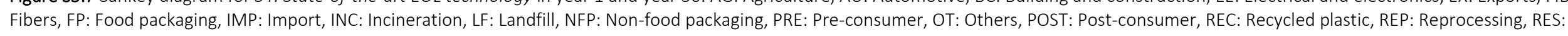
Residual waste, SOR: Sorting, SS: Source-separated waste. 


\begin{tabular}{|c|c|c|c|c|c|c|c|c|c|c|c|c|c|c|c|c|c|c|c|c|c|c|c|}
\hline From & To & Pac F 2D & $\begin{array}{l}\text { Food pack. } \\
\text { Pac F B }\end{array}$ & & $=\mathrm{nF}^{1}$ & $\begin{array}{l}\text { on-food pa } \\
\text { Pac nF B }\end{array}$ & $\begin{array}{l}\text { ck. } \\
\text { Pac nF OR }\end{array}$ & & $\begin{array}{l}\text { Agricultt } \\
\text { 2D Agro F }\end{array}$ & $\begin{array}{l}\text { ure } \\
\text { P Agro C }\end{array}$ & & $\begin{array}{r}\text { Autc } \\
\text { Auto } 21\end{array}$ & $\begin{array}{l}\text { omotive } \\
\text { D Auto OR }\end{array}$ & C $2 \mathrm{D}$ & $\begin{array}{l}B \& C \\
B C P\end{array}$ & & $\begin{array}{r}\text { Elect } \\
\text { Electro } 2 \mathrm{D}\end{array}$ & $\begin{array}{l}\text { Elonics } \\
\text { Electro OR }\end{array}$ & \begin{tabular}{|l|} 
Fibers \\
Fibers
\end{tabular} & Other 20 & $\begin{array}{c}\text { Others } \\
\text { Other Fu }\end{array}$ & Other $\mathrm{OR}$ & SUM \\
\hline Recycled & Trade & & & & & & & & & & & & & & & & & & & & & & \\
\hline Virgin & Trade & 179630 & 622840 & 1245681 & 131973 & 956073 & 478036 & 0 & 6871 & 0 & & 0 & 2131 & 0 & 0 & 0 & 0 & 9590 & 1800000 & 0 & 0 & 16725 & $\begin{array}{c}0 \\
5449551\end{array}$ \\
\hline Import & Trade & 0 & 0 & 0 & 0 & 0 & 0 & 0 & 0 & 0 & & 0 & 0 & 0 & 0 & 0 & 0 & 4492 & 1035100 & 0 & 0 & 3752 & 1043343 \\
\hline Trade & Use & 151133 & 524031 & 1048062 & 111037 & 804398 & 402199 & 0 & 6404 & 0 & & 0 & 1698 & 0 & 0 & 0 & 0 & 13515 & 2709100 & 0 & 0 & 19306 & 5790884 \\
\hline Trade & Exports & 13947 & 48359 & 96719 & 10247 & 74233 & 37116 & 0 & 0 & 0 & & 0 & 312 & 0 & 0 & 0 & 0 & 0 & 0 & 0 & 0 & 0 & 280933 \\
\hline Trade & Source-separation & 14550 & 50450 & 100900 & 10690 & 77442 & 38721 & 0 & 467 & 0 & & 0 & 121 & 0 & 0 & 0 & 0 & 566 & 126000 & 0 & 0 & 1171 & 421078 \\
\hline Use & Source-separation & 151133 & 524031 & 1048062 & 111037 & 804398 & 402199 & 0 & 1864 & 0 & & 0 & 1286 & 0 & 0 & 0 & 0 & 1699 & 2199384 & 0 & 0 & 14253 & 5259346 \\
\hline Use & Stock & 0 & 0 & 0 & 0 & 0 & 0 & 0 & 4540 & 0 & & 0 & 411 & 0 & 0 & 0 & 0 & 11816 & 509716 & 0 & 0 & 5053 & 531537 \\
\hline Source-separation & Separate collection & 105038 & 304462 & 572242 & 77170 & 467355 & 219601 & 0 & 1118 & 0 & & 0 & 0 & 0 & 0 & 0 & 0 & 586 & 1099692 & 0 & 0 & 4433 & 2851697 \\
\hline Source-separation & Residual collection & 46096 & 219569 & 475820 & 33866 & 337043 & 182598 & 0 & 745 & 0 & & 0 & 1286 & 0 & 0 & 0 & 0 & 1113 & 1099692 & 0 & 0 & 9820 & 2407649 \\
\hline Separate collection & Exports & 30740 & 89102 & 167468 & 22584 & 136773 & 64267 & 0 & 8 & 0 & & 0 & 0 & 0 & 0 & 0 & 0 & 0 & \begin{tabular}{|c|c|}
93757 \\
\end{tabular} & 0 & 0 & 30 & 604728 \\
\hline Separate collection & Plastic sorting & 74298 & 215360 & 404774 & 54586 & 330583 & 155334 & 0 & 1111 & 0 & & 0 & 0 & 0 & 0 & 0 & 0 & 586 & 1005935 & 0 & 0 & 4403 & 2246969 \\
\hline Plastic sorting & Incineration & 7626 & 22105 & 41547 & 5603 & 33931 & 15944 & 0 & 114 & 0 & & 0 & 0 & 0 & 0 & 0 & 0 & 60 & 103251 & 0 & 0 & 452 & 230632 \\
\hline Plastic sorting & Landfill & 5005 & 14506 & 27265 & 3677 & 22268 & 10463 & 0 & 75 & 0 & & 0 & 0 & 0 & 0 & 0 & 0 & 39 & 67758 & 0 & 0 & 297 & 151352 \\
\hline Prod_con_w & Prod_con_w & 14550 & 50450 & 100900 & 10690 & 77442 & 38721 & 0 & 467 & 0 & & 0 & 121 & 0 & 0 & 0 & 0 & 566 & 126000 & 0 & 0 & 1171 & 421078 \\
\hline Plastic sorting & Recycling & 61667 & 178749 & 335962 & 45307 & 274384 & 128927 & 0 & 922 & 0 & & 0 & 0 & 0 & 0 & 0 & 0 & 487 & 834926 & 0 & 0 & 3654 & 1864984 \\
\hline Residual collection & Incineration & 27831 & 132570 & 287288 & 20447 & 203498 & 110248 & 0 & 450 & 0 & & 0 & 1286 & 0 & 0 & 0 & 0 & 672 & 663965 & 0 & 0 & 5929 & 1454185 \\
\hline Residual collection & Landfill & 18264 & 86999 & 188532 & 13419 & 133545 & 72350 & 0 & 295 & 0 & & 0 & 0 & 0 & 0 & 0 & 0 & 441 & 435727 & 0 & 0 & 3891 & 953465 \\
\hline Residual collection & Recycling & 0 & 0 & 0 & 0 & 0 & 0 & 0 & 0 & 0 & & 0 & 0 & 0 & 0 & 0 & 0 & 0 & 0 & 0 & 0 & 0 & 0 \\
\hline Recycling & Landfill & 4154 & 12040 & 22630 & 3052 & 18482 & 8684 & 0 & 62 & 0 & & 0 & 0 & 0 & 0 & 0 & 0 & 33 & 56239 & 0 & 0 & 246 & 125623 \\
\hline Prod_con_w & Prod_con_w & 14550 & 50450 & 100900 & 10690 & 77442 & 38721 & 0 & 467 & 0 & & 0 & 121 & 0 & 0 & 0 & 0 & 566 & 126000 & 0 & 0 & 1171 & 421078 \\
\hline
\end{tabular}

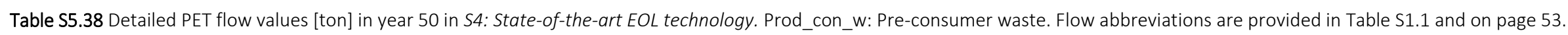

\begin{tabular}{|c|c|c|c|c|c|c|c|c|c|c|c|c|c|c|c|c|c|c|c|c|c|c|}
\hline \multirow[b]{2}{*}{ From } & \multirow[b]{2}{*}{ To } & \multicolumn{3}{|c|}{ Food pack. } & \multicolumn{3}{|c|}{ Non-food pack. } & \multicolumn{3}{|c|}{ Agriculture } & \multicolumn{2}{|c|}{ Automotive } & \multicolumn{3}{|c|}{$B \& C$} & \multicolumn{2}{|c|}{ Electronics } & \multirow{2}{*}{$\begin{array}{l}\text { Fibers } \\
\text { Fibers }\end{array}$} & \multicolumn{3}{|c|}{ Others } & \multirow{2}{*}{ SUM } \\
\hline & & Pac_F_2D & Pac_F_B & Pac_F_OR & Pac_nF_2D & Pac_nF_B & Pac_nF_OR & Agro_2D & Agro_p & Agro_OR & Auto_2D & Auto_OR & BC_2D & BC_P & BC_OR & R Electro_2D & Electro_OR & & Other_2D & Other_Fu & 1 Other_OR & \\
\hline Recycled & Trade & 81633 & 372152 & 2069895 & 59975 & 683625 & 1661381 & 0 & 24743 & 0 & 0 & 681 & 0 & 0 & 0 & 0 & 13625 & \begin{tabular}{|l|}
5089043 \\
\end{tabular} & 0 & 0 & 21029 & 10077785 \\
\hline Virgin & Trade & 506025 & 1572199 & 4732707 & 371774 & 2300994 & 949152 & 0 & 43529 & 0 & 0 & 20493 & 0 & 0 & 0 & 0 & 43822 & 11995921 & 0 & 0 & 68216 & 22604832 \\
\hline Import & Trade & 0 & 0 & 0 & 0 & 0 & 0 & 0 & 0 & 0 & 0 & 0 & 0 & 0 & 0 & 0 & 4492 & 1035100 & 0 & 0 & 3752 & 1043343 \\
\hline Trade & Use & 494431 & 1635893 & 5723416 & 363255 & 2511130 & 2196390 & 0 & 63630 & 0 & 0 & 16868 & 0 & 0 & 0 & 0 & 58549 & $\mid 16924117$ & 0 & 0 & 86749 & 30074428 \\
\hline Trade & Exports & 45628 & 150966 & 528176 & 33522 & 231735 & 202690 & 0 & 0 & 0 & 0 & 3099 & 0 & 0 & 0 & 0 & 0 & 0 & 0 & 0 & 0 & 1195816 \\
\hline Trade & Source-separation & 47600 & 157492 & 551011 & 34972 & 241754 & 211453 & 0 & 4643 & 0 & 0 & 1207 & 0 & 0 & 0 & 0 & 3389 & $\mid 1195947$ & 0 & 0 & 6247 & 2455716 \\
\hline Use & Source-separation & 494431 & 1635893 & 5723416 & 363255 & 2511130 & 2196390 & 0 & 56523 & 0 & 0 & 9373 & 0 & 0 & 0 & 0 & 45475 & 13934605 & 0 & 0 & 70231 & 27040722 \\
\hline Use & Stock & 0 & 0 & 0 & 0 & 0 & 0 & 0 & 7107 & 0 & 0 & 7495 & 0 & 0 & 0 & 0 & 13074 & 2989512 & 0 & 0 & 16519 & 3033706 \\
\hline Source-separation & Separate collection & 343629 & 950454 & 3124985 & 252462 & 1458966 & 1199229 & 0 & 33914 & 0 & 0 & 0 & 0 & 0 & 0 & 0 & 15689 & \begin{tabular}{|l|}
6967303 \\
\end{tabular} & 0 & 0 & 21842 & 14368473 \\
\hline Source-separation & Residual collection & 150801 & 685439 & 2598431 & 110793 & 1052163 & 997161 & 0 & 22609 & 0 & 0 & 9373 & 0 & 0 & 0 & 0 & 29786 & \begin{tabular}{|l|}
6967303 \\
\end{tabular} & 0 & 0 & 48389 & 12672249 \\
\hline Separate collection & Exports & 100564 & 278153 & 914536 & 73884 & 426971 & 350958 & 0 & 229 & 0 & 0 & 0 & 0 & 0 & 0 & 0 & 1 & \begin{tabular}{|l|}
594016 \\
\end{tabular} & 0 & 0 & 147 & 2739458 \\
\hline Separate collection & Plastic sorting & 243065 & 672301 & 2210449 & 178578 & 1031996 & 848271 & 0 & 33685 & 0 & 0 & 0 & 0 & 0 & 0 & 0 & 15688 & $\mid 6373287$ & 0 & 0 & 21694 & 11629015 \\
\hline Plastic sorting & Incineration & 24949 & 69006 & 226884 & 18330 & 105926 & 87068 & 0 & 3457 & 0 & 0 & 0 & 0 & 0 & 0 & 0 & 1610 & 654164 & 0 & 0 & 2227 & 1193620 \\
\hline Plastic sorting & Landfill & 16373 & 45285 & 148893 & 12029 & 69514 & 57138 & 0 & 2269 & 0 & 0 & 0 & 0 & 0 & 0 & 0 & 1057 & 429295 & 0 & 0 & 1461 & 783313 \\
\hline Prod_con_w & Prod_con_w & 47600 & 157492 & 551011 & 34972 & 241754 & 211453 & 0 & 4643 & 0 & 0 & 1207 & 0 & 0 & 0 & 0 & 3389 & $\mid 1195947$ & 0 & 0 & 6247 & 2455716 \\
\hline Plastic sorting & Recycling & 201744 & 558010 & 1834673 & 148220 & 856557 & 704065 & 0 & 27959 & 0 & 0 & 0 & 0 & 0 & 0 & 0 & 13021 & 5289828 & 0 & 0 & 18006 & 9652082 \\
\hline Residual collection & Incineration & 91050 & 413850 & 1568864 & 66894 & 635268 & 602060 & 0 & 13651 & 0 & 0 & 9373 & 0 & 0 & 0 & 0 & 17984 & \begin{tabular}{|l|}
4206673 \\
\end{tabular} & 0 & 0 & 29216 & 7654883 \\
\hline Residual collection & Landfill & 59751 & 271589 & 1029567 & 43899 & 416895 & 395102 & 0 & 8958 & 0 & 0 & 0 & 0 & 0 & 0 & 0 & 11802 & 2760629 & 0 & 0 & 19173 & 5017366 \\
\hline Residual collection & Recycling & 0 & 0 & 0 & 0 & 0 & 0 & 0 & 0 & 0 & 0 & 0 & 0 & 0 & 0 & 0 & 0 & 0 & 0 & 0 & 0 & 0 \\
\hline Recycling & Landfill & 13589 & 37587 & 123581 & 9984 & 57696 & 47425 & 0 & 1883 & 0 & 0 & 0 & 0 & 0 & 0 & 0 & 877 & 356315 & 0 & 0 & 1213 & 650150 \\
\hline Prod_con_w & Prod_con_w & 84855 & 294223 & 588447 & 62343 & 451639 & 225819 & 0 & 2725 & 0 & 0 & 708 & 0 & 0 & 0 & 0 & 3300 & 734828 & 0 & 0 & 6828 & 2455716 \\
\hline
\end{tabular}




\begin{tabular}{|c|c|c|c|c|c|c|c|c|c|c|c|c|c|c|c|c|c|c|c|c|c|c|}
\hline From & To & \multicolumn{3}{|c|}{ Food pack. } & \multicolumn{3}{|c|}{ Non-food pack. } & \multicolumn{3}{|c|}{ Agriculture } & \multicolumn{2}{|c|}{$\begin{array}{l}\text { Automotive } \\
\text { uto_2D Auto_OR }\end{array}$} & \multicolumn{3}{|c|}{$B \& C$} & \multicolumn{2}{|c|}{ Electronics } & $\begin{array}{ll}\text { Fibers } \\
\text { Fibers } \\
\end{array}$ & \multicolumn{3}{|c|}{ Others } & SUM \\
\hline Recycled & Trade & & & & & & & & & & & & & & & & & & & & & $\begin{array}{lll}0 & & \\
\end{array}$ \\
\hline Virgin & Trade & 197128 & 397936 & 161611 & 2407793 & 1760749 & 118994 & 365360 & 77688 & 60790 & 0 & 517785 & 548048 & 1201236 & 0 & 0 & 421489 & 0 & 0 & 255741 & 1742712 & 14535062 \\
\hline Import & Trade & 0 & 0 & 0 & 0 & 0 & 0 & 0 & 0 & 0 & 0 & 0 & 6579 & 14421 & 0 & 0 & 197000 & 1035100 & 0 & 57378 & 390998 & 1701477 \\
\hline $\begin{array}{l}\text { Trade } \\
\text {. }\end{array}$ & Use & 997268 & 336008 & 136460 & 2033083 & 1486734 & 100476 & 340516 & 72405 & 56656 & 0 & 412484 & 516812 & 1132772 & 0 & 0 & 593621 & 1035100 & 0 & 295217 & 2011721 & 14357335 \\
\hline Trade & Exports & 5593 & 29696 & 12060 & 79679 & 131394 & 8880 & 0 & 0 & 0 & 0 & 75787 & 0 & 0 & 0 & 0 & 0 & 0 & c & 0 & 0 & 773088 \\
\hline Trade & Source-separation & 4267 & 32233 & 13090 & 95031 & 142621 & 9639 & 24844 & 5283 & 4134 & 0 & 29514 & 37815 & 82885 & 0 & 0 & 24868 & 0 & 0 & 17902 & 121990 & 1106116 \\
\hline Use & Source-separation & \begin{tabular}{|l|}
3797267 \\
\end{tabular} & 336008 & 136460 & 2033083 & 1486734 & 100476 & 303062 & 65499 & 49178 & 8 & 177242 & 20233 & 45036 & 0 & 0 & 304765 & 840346 & & 237430 & 1679990 & 11612809 \\
\hline Use & Stock & 1 & 0 & 0 & 1 & 0 & 0 & 37454 & 6906 & 7479 & 0 & 235242 & 496579 & 1087736 & $c$ & 0 & 288856 & 194754 & & 57787 & 331731 & 2744526 \\
\hline Source-separation & Separate colle & 2126469 & 149869 & 28873 & 1138526 & 663124 & 21259 & 181837 & 39299 & 29507 & 0 & 0 & \begin{tabular}{|l|}
5564 \\
\end{tabular} & 10133 & 0 & 0 & 105144 & 420173 & c & 73841 & 522477 & 5516095 \\
\hline ource & Prod_con_w & 4267 & 32233 & 13090 & 95031 & 142621 & 9639 & 24844 & 5283 & 4134 & 0 & 29514 & 37815 & 82885 & 0 & 0 & 24868 & 0 & c & 17902 & 121990 & 1106116 \\
\hline Source-separation & Residual colle & 70797 & 186139 & 107587 & 94556 & 823610 & 79217 & 121225 & 26200 & 19671 & 0 & 177242 & 14669 & 34903 & c & 0 & 199621 & 420173 & c & 163589 & 1157513 & 6096714 \\
\hline Separate collection & Exports & 06511 & 56841 & 10951 & 31812 & 251504 & 8063 & 1569 & 339 & 255 & 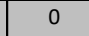 & 0 & 0 & 0 & 0 & 0 & 9 & 0 & 0 & 637 & 4508 & 1572999 \\
\hline eparate collection & Plastic sor & 1319958 & 93028 & 17922 & 06715 & 411619 & 13196 & 180268 & 38960 & 29252 & 0 & 0 & 5564 & 10133 & 0 & 0 & 105135 & 420173 & & 73204 & 517969 & 3943096 \\
\hline Plastic sorting & Incineratic & 95635 & 6740 & 1299 & 51203 & 29823 & 956 & 13061 & 2823 & 2119 & 0 & 0 & 484 & 784 & 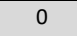 & 0 & 7617 & 50421 & & 5304 & 37528 & 305797 \\
\hline Plastic & Landfill & & 4423 & 852 & 3602 & 19571 & 627 & 8571 & 1852 & 1391 & 0 & 0 & 184 & 431 & 0 & 0 & 4999 & 0 & c & 3481 & 24628 & 167374 \\
\hline Prod_con_w & Prod_con_w & 64267 & 32233 & 13090 & 195031 & 142621 & 9639 & 24844 & 5283 & 4134 & 0 & 29514 & 37815 & 82885 & 0 & 0 & 24868 & 0 & 6 & 17902 & 121990 & 1106116 \\
\hline Plastic sorting & Recycling & 1161563 & 81864 & 15771 & 621909 & 362225 & 11613 & 158636 & 34285 & 25742 & 0 & 0 & 4896 & 8917 & 0 & 0 & 92519 & 369752 & 0 & 64419 & 455812 & 3469924 \\
\hline Residual collection & Incineratio & \begin{tabular}{|l|}
1002478 \\
\end{tabular} & 111684 & 64552 & 536734 & 494166 & 47530 & 72735 & 15720 & 11803 & 0 & 159518 & 10623 & 22518 & c & 0 & 119773 & 420173 & & 98154 & 694508 & 3882668 \\
\hline Residual collection & Landfill & 68319 & 74456 & 43035 & 357823 & 329444 & 31687 & 48490 & 10480 & 7868 & 0 & 17724 & 4047 & 12385 & ( & 0 & 79849 & 0 & c & 65436 & 463005 & 2214046 \\
\hline Residual collection & Recycling & 0 & 0 & 0 & 0 & 0 & 0 & 0 & 0 & 0 & 0 & 0 & 0 & 0 & 0 & 0 & 0 & 0 & 0 & 0 & 0 & 0 \\
\hline Recycling & Recycled raw material & 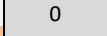 & 0 & 0 & 825396 & 188738 & 0 & 67420 & 29142 & 21881 & 0 & 0 & 2081 & 3790 & ( & 0 & 78641 & 314290 & & 242497 & 1175560 & 2949436 \\
\hline Recy & & 105198 & 7414 & 1428 & 50324 & 32805 & 1052 & 14367 & 3105 & 2331 & 0 & 0 & 532 & 863 & c & 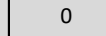 & 8379 & 55463 & 0 & 5834 & 41281 & 336377 \\
\hline Recycling & Landfill & 69036 & 4866 & 937 & 36963 & 21528 & 690 & 9428 & 2038 & 1530 & 0 & 0 & 203 & 475 & 0 & 0 & 5499 & 0 & 0 & 3829 & 27091 & 184112 \\
\hline Prod_con_w & Prod_con_w & 364267 & 32233 & 13090 & 195031 & 142621 & 9639 & 24844 & 5283 & 4134 & 0 & 29514 & 37815 & 82885 & 0 & 0 & 24868 & 0 & 0 & 17902 & 121990 & 1106116 \\
\hline
\end{tabular}

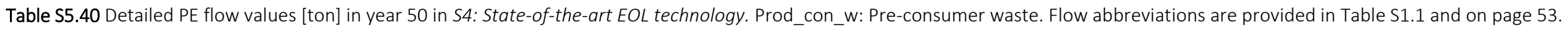

\begin{tabular}{|c|c|c|c|c|c|c|c|c|c|c|c|c|c|c|c|c|c|c|c|c|c|c|}
\hline \multirow{2}{*}{ From } & \multirow{2}{*}{ To } & \multicolumn{3}{|c|}{ Food pack. } & \multicolumn{3}{|c|}{ Non-food pack. } & \multicolumn{3}{|c|}{ Agriculture } & \multirow{2}{*}{\multicolumn{2}{|c|}{$\begin{array}{c}\text { Automotive } \\
\text { Auto 2D Auto OR }\end{array}$}} & \multicolumn{3}{|c|}{$B \& C$} & \multirow{2}{*}{\multicolumn{2}{|c|}{$\begin{array}{l}\text { Electronics } \\
\text { tro 2D Electro OR }\end{array}$}} & \multirow{2}{*}{$\begin{array}{l}\text { Fibers } \\
\text { Fibers }\end{array}$} & \multirow{2}{*}{\multicolumn{2}{|c|}{$\begin{array}{c}\text { Others } \\
\text { Other_2D Other_Fu }\end{array}$}} & \multirow{2}{*}{ Other_OR } & \multirow{2}{*}{ SUM } \\
\hline & & Pac_F_2D & & C_F_OR & & & c_nf_OP & & & ro_OR & & D Auto_OR & BC_2D & BC_P & BC_OR & & D Electro_OR & & & & & \\
\hline Recycled & Trade & $\mid 1769076$ & 156540 & 63574 & 4676928 & 1885053 & 46810 & 519206 & 195145 & 152700 & 0 & 143334 & 259864 & 539254 & 0 & 0 & 413590 & 0 & 0 & 1243419 & 6147304 & 18211798 \\
\hline Virgin & Trade & 18627664 & 2458112 & 669411 & 6243627 & 9683997 & 492889 & 1669533 & 270254 & 211472 & 0 & 5001519 & 1803084 & 3982407 & 0 & 0 & 784334 & 0 & 0 & 121179 & 3151577 & 55171060 \\
\hline Import & Trade & 0 & 0 & 0 & 0 & 0 & 0 & 0 & 0 & 0 & 0 & 0 & 6579 & 14421 & 0 & 0 & 197000 & 1035100 & 0 & 57378 & 390998 & 1701477 \\
\hline Trade & Use & 17222521 & 2207750 & 618915 & 9221056 & 9768630 & 455709 & 2039905 & 433752 & 339408 & 0 & 4098556 & 1927184 & 4224087 & 0 & 0 & 1324247 & 1035100 & 0 & 1326455 & 9038957 & 65282233 \\
\hline Trade & Exports & 1522083 & 195115 & 54698 & 814934 & 863327 & 40274 & 0 & 0 & 0 & 0 & 753041 & 0 & 0 & 0 & 0 & 0 & 0 & 0 & 0 & 0 & 4243473 \\
\hline Trade & Source-separation & 1652136 & 211787 & 59372 & 884565 & 937093 & 43716 & 148834 & 31647 & 24764 & 0 & 293257 & 142343 & 311995 & 0 & 0 & 70678 & 0 & 0 & 95522 & 650922 & 5558629 \\
\hline Use & Source-separation & 17222521 & 2207750 & 618915 & 9221056 & 9768630 & 455709 & 1859597 & 395413 & 309408 & 0 & 2277459 & 761526 & 1669520 & 0 & 0 & 1155422 & 1035100 & 0 & 1073876 & 7317794 & 57349694 \\
\hline Use & Stock & 0 & 0 & 0 & 0 & 0 & 0 & 180308 & 38340 & 30001 & 0 & 1821097 & 1165658 & 2554568 & 0 & 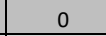 & 168825 & 0 & 0 & 252578 & 1721163 & 7932538 \\
\hline Source-separation & Separate collection & 9644612 & 984716 & 130952 & 5163791 & 4357073 & 96420 & 1115758 & 237248 & 185645 & 0 & 0 & 209420 & 375642 & S & 0 & 398621 & 17550 & 0 & 333976 & 2275834 & 26027256 \\
\hline Source-separation & Residual collection & 7577909 & 1223034 & 487963 & 4057264 & 5411557 & 359289 & 743839 & 158165 & 123763 & 0 & 2277459 & 552106 & 1293878 & 0 & 0 & 756801 & 517550 & 0 & 739901 & 5041960 & 31322439 \\
\hline Separate collection & Exports & 3657934 & 373476 & 49666 & 1958483 & 1652517 & 36569 & 9627 & 2047 & 1602 & 0 & 0 & 0 & 0 & 0 & 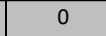 & 35 & 0 & 0 & 2882 & 19637 & 7764476 \\
\hline Separate collection & Plastic sorting & 5986677 & 611240 & 81285 & 3205308 & 2704556 & 59851 & 1106131 & 235201 & 184043 & 0 & 0 & 209420 & 375642 & 0 & 0 & 398585 & 517550 & 0 & 331094 & 2256197 & 18262779 \\
\hline Plastic sorting & Incineration & 433752 & 44286 & 5889 & 232234 & 195953 & 4336 & 80142 & 17041 & 13334 & 0 & 0 & 18198 & 29082 & 0 & 0 & 28879 & 62106 & 0 & 23989 & 163468 & 1352689 \\
\hline Plastic sorting & Landfill & 284650 & 29063 & 3865 & 152403 & 128594 & 2846 & 52593 & 11183 & 8751 & 0 & 0 & 6933 & 15995 & 0 & 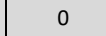 & 18952 & 0 & 0 & 15743 & 107276 & 838845 \\
\hline Prod_con_w & Prod_con_w & 1652136 & 211787 & 59372 & 884565 & 937093 & 43716 & 148834 & 31647 & 24764 & 0 & 293257 & 142343 & 311995 & 0 & 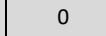 & 70678 & 0 & 0 & 95522 & 650922 & 5558629 \\
\hline Plastic sorting & Recycling & 5268276 & 537892 & 71531 & 2820671 & 2380009 & 52669 & 973395 & 206977 & 161958 & 0 & 0 & 184289 & 330565 & 0 & 0 & 350755 & 455444 & 0 & 291363 & 1985453 & 16071246 \\
\hline Residual collection & Incineration & 4546745 & 733820 & 292778 & 2434359 & 3246934 & 215573 & 446303 & 94899 & 74258 & 0 & 2049713 & 399801 & 834760 & 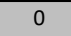 & 0 & 454081 & 517550 & 0 & 443940 & 3025176 & 19810691 \\
\hline Residual collection & Landfill & 3031164 & 489213 & 195185 & 1622906 & 2164623 & 143716 & 297535 & 63266 & 49505 & 0 & 227746 & 152305 & 459118 & 0 & 0 & 302721 & 0 & 0 & 295960 & 2016784 & 11511747 \\
\hline Residual collection & Recyclin & 0 & 0 & 0 & 0 & 0 & 0 & 0 & 0 & 0 & 0 & 0 & 0 & 0 & 0 & 0 & 0 & 0 & 0 & 0 & 0 & 0 \\
\hline Recycling & Recycled raw material & 0 & 0 & 0 & 3851495 & 1240108 & 0 & 413693 & 175930 & 137664 & 0 & 0 & 78323 & 140490 & 0 & 0 & 298142 & 387127 & 0 & 1195870 & 5741716 & 13660559 \\
\hline Recycling & Landfill & 313115 & 31969 & 4251 & 167644 & 141453 & 3130 & 57853 & 12301 & 9626 & 0 & 0 & 7626 & 17595 & 0 & 0 & 20847 & 0 & 0 & 17317 & 118003 & 922730 \\
\hline Prod_con_w & Prod_con_w & 1830574 & 161982 & 65784 & 980102 & 716720 & 48437 & 124852 & 26548 & 20773 & 0 & 148317 & 190036 & 416528 & 0 & 0 & 124970 & 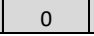 & 0 & 89963 & 613043 & 5558629 \\
\hline
\end{tabular}




\begin{tabular}{|c|c|c|c|c|c|c|c|c|c|c|c|c|c|c|c|c|c|c|c|c|c|c|}
\hline From & To & Pac_F_2D & $\begin{array}{l}\text { Food pack. } \\
\text { Pac_F_B }\end{array}$ & Pac_F_OR & $\begin{array}{r}N \\
\text { Pac_nF_2D }\end{array}$ & $\begin{array}{l}\text { on-food pa } \\
\text { Pac_nF_B }\end{array}$ & K. & Agro_2L & $\begin{array}{l}\text { Agricultur } \\
\text { Agro_P }\end{array}$ & Agro_OR & $\begin{array}{r}\text { Auto } \\
\text { Auto_2D }\end{array}$ & $\begin{array}{l}\text { motive } \\
\text { Auto_OR }\end{array}$ & BC_2D & $\begin{array}{l}\text { B\&C } \\
B C \_P\end{array}$ & BC_OR & $\begin{array}{r}\text { Ele } \\
\text { Electro_2 }\end{array}$ & $\begin{array}{l}\text { onics } \\
\text { Electro_OR }\end{array}$ & \begin{tabular}{|l|} 
Fibers \\
Fibers
\end{tabular} & Other_2D & $\begin{array}{c}\text { Others } \\
\text { Other_Fu }\end{array}$ & Other_OR & SUM \\
\hline Recycled & Trade & & & & & & & & & & & & & & & & & & & & & \\
\hline Virgin & Trade & 791484 & 0 & 1244000 & 878460 & 921948 & 461000 & 0 & 0 & 607764 & 0 & 1298633 & 0 & 792627 & 0 & 0 & 482876 & 2000000 & 0 & 177481 & 1879215 & 11535489 \\
\hline Import & Trade & 0 & 0 & 0 & 0 & 0 & 0 & 0 & 0 & 0 & 0 & 0 & 0 & 9000 & 0 & 0 & 226000 & 1035100 & 0 & 39780 & 421200 & 1731080 \\
\hline Trade & Use & 495870 & 0 & 779444 & 550361 & 577607 & 288827 & 0 & 0 & 566436 & 0 & 1034611 & 0 & 755936 & 0 & 0 & 680387 & 2895100 & 0 & 244618 & 2168870 & 11038065 \\
\hline Trade & Exports & 231504 & 0 & 363792 & 256944 & 269664 & 134832 & 0 & 0 & 0 & 0 & 190000 & 0 & -9000 & 0 & 0 & 0 & 0 & 0 & -39780 & 0 & 1397956 \\
\hline Trade & Source-separation & 64110 & 0 & 100764 & 71155 & 74678 & 37341 & 0 & 0 & 41328 & 0 & 74022 & 0 & 54691 & 0 & 0 & 28490 & 140000 & 0 & 12424 & 131545 & 830548 \\
\hline Use & Source-separation & 495870 & 0 & 779444 & 550361 & 577606 & 288827 & 295315 & 63852 & 60775 & 0 & 593697 & 0 & 28755 & 0 & 0 & 304786 & 2350388 & 0 & 236279 & 1683565 & 8309520 \\
\hline Use & Stock & 0 & 0 & 0 & 0 & 0 & 0 & -295315 & -63852 & 505660 & 0 & 440914 & 0 & 727180 & 0 & 0 & 375601 & 544712 & 0 & 8339 & 485305 & 2728546 \\
\hline Source-separation & Separate collection & 344629 & 0 & 0 & 382501 & 258768 & 0 & \begin{tabular}{|l|l}
177189 \\
\end{tabular} & 38311 & 36465 & 0 & 0 & 0 & 20129 & 0 & 0 & 105151 & 1175194 & 0 & 73483 & 523589 & 3135408 \\
\hline Source-separation & Prod_con_w & 64110 & 0 & 100764 & 71155 & 74678 & 37341 & 0 & 0 & 41328 & 0 & 74022 & 0 & 54691 & 0 & 0 & 28490 & 140000 & 0 & 12424 & 131545 & 830548 \\
\hline Source-separation & Residual collection & 151240 & 0 & 779444 & 167860 & 318839 & 288827 & 118126 & 25541 & 24310 & 0 & 593697 & 0 & 8627 & 0 & 0 & 199635 & 1175194 & 0 & 162796 & 1159976 & 5174111 \\
\hline Separate collection & Exports & 56366 & 0 & 0 & 62561 & 42323 & 0 & 0 & 0 & 136 & 0 & 0 & 0 & 0 & 0 & 0 & 4 & 21548 & 0 & 273 & 1948 & 185160 \\
\hline Separate collection & Plastic sorting & 288263 & 0 & 0 & 319940 & 216444 & 0 & 177189 & 38311 & 36330 & 0 & 0 & 0 & 20129 & 0 & 0 & 105147 & 1153646 & 0 & 73209 & 521640 & 2950248 \\
\hline Plastic sorting & Incineration & 52214 & 0 & 0 & 57951 & 39205 & 0 & 32095 & 6939 & 6580 & 0 & 0 & 0 & 3944 & 0 & 0 & 19045 & 208962 & 0 & 13261 & 94486 & 534682 \\
\hline Plastic sorting & Landfill & 34265 & 0 & 0 & 38031 & 25728 & 0 & 21062 & 4554 & 4318 & 0 & 0 & 0 & 2095 & 0 & 0 & 12499 & 137131 & 0 & 8702 & 62006 & 350392 \\
\hline Prod_con_w & Prod_con_w & 64110 & 0 & 100764 & 71155 & 74678 & 37341 & 0 & 0 & 41328 & 0 & 74022 & 0 & 54691 & 0 & 0 & 28490 & 140000 & 0 & 12424 & 131545 & 830548 \\
\hline Plastic sorting & Recycling & 201784 & 0 & 0 & 223958 & 151511 & 0 & 124032 & 26818 & 25431 & 0 & 0 & 0 & 14090 & 0 & 0 & 73603 & 807552 & 0 & 51247 & 365148 & 2065174 \\
\hline Residual collection & Incineration & 90744 & 0 & 467666 & 100716 & 191303 & 173296 & 70876 & 15324 & 14586 & 0 & 534328 & 0 & 5634 & 0 & 0 & 119781 & \begin{tabular}{|l|}
709551 \\
\end{tabular} & 0 & 97678 & 695986 & 3287468 \\
\hline Residual collection & Landfill & 60496 & 0 & 311778 & 67144 & 127536 & 115531 & 47250 & 10216 & 9724 & 0 & 59370 & 0 & 2993 & 0 & 0 & 79854 & 465643 & 0 & 65118 & 463990 & 1886643 \\
\hline Residual collection & Recycling & 0 & 0 & 0 & 0 & 0 & 0 & 0 & 0 & 0 & 0 & 0 & 0 & 0 & 0 & 0 & 0 & 0 & 0 & 0 & 0 & 0 \\
\hline Recycling & Recycled raw material & 0 & 0 & 0 & 34726 & 0 & 0 & 0 & 0 & 21362 & 0 & 0 & 0 & 5918 & 0 & 0 & 61826 & $\mid 678344$ & 0 & 121223 & 719359 & 1642758 \\
\hline Recycling & Landfill & 12792 & 0 & 0 & 14198 & 9605 & 0 & 7866 & 1700 & 1612 & 0 & 0 & 0 & 782 & 0 & 0 & 4666 & 0 & 0 & 3249 & 23149 & 79620 \\
\hline Prod_con_w & Prod_con_w & 64112 & 0 & 100747 & 71157 & 74680 & 37340 & 0 & 0 & 41329 & 0 & 74024 & 0 & 54693 & 0 & 0 & 28490 & 140004 & 0 & 12424 & 131548 & 830548 \\
\hline Recycling & Surplus/loss & & & & & & & & & & & & & & & & & & & & & 91981 \\
\hline
\end{tabular}

Table S5.42 Detailed PP flow values [ton] in year 50 in S4: State-of-the-art EOL technology. Prod_con_w: Pre-consumer waste. Flow abbreviations are provided in Table S1.1 and on page 53.

\begin{tabular}{|c|c|c|c|c|c|c|c|c|c|c|c|c|c|c|c|c|c|c|c|c|c|c|}
\hline \multirow[b]{2}{*}{ From } & \multirow[b]{2}{*}{ To } & \multicolumn{3}{|c|}{ Food pack. } & \multicolumn{3}{|c|}{ Non-food pack. } & \multicolumn{3}{|c|}{ Agriculture } & \multicolumn{2}{|c|}{ Automotive } & \multicolumn{3}{|c|}{$B \& C$} & \multirow{2}{*}{\multicolumn{2}{|c|}{$\begin{array}{l}\text { Electronics } \\
\text { ro 2D Electro OR }\end{array}$}} & \multirow{2}{*}{$\begin{array}{l}\text { Fibers } \\
\text { Fibers }\end{array}$} & \multicolumn{3}{|c|}{ Others } & \multirow{2}{*}{ SUM } \\
\hline & & Pac_F_2D & & Pac_F_OR & Pac_nF_2D & Pac_nF_B & Pac_nF_OF & Agro_2D & Agro & P Agro_OR & Auto_2D & Auto_OR & BC_2D & BC_P & BC_OR & & & & Other_2 & Other_Fu & Other_OR & \\
\hline Recycled & Trade & 383623 & 0 & 602837 & 425780 & 446858 & 223429 & 0 & 0 & 1922529 & 0 & 442934 & 0 & 550264 & 0 & 0 & 619627 & 5083586 & 0 & 607101 & 4160607 & 15469176 \\
\hline Virgin & Trade & 3206155 & 0 & 4782791 & 3558480 & 3734642 & 1772370 & 0 & 0 & 4116375 & 0 & 12460640 & 0 & 2433320 & 0 & 0 & 2273111 & |13899708 & 0 & 339916 & 5866632 & 58444139 \\
\hline Import & Trade & 0 & 0 & 0 & 0 & 0 & 0 & 0 & 0 & 0 & 0 & 0 & 0 & 9000 & 0 & 0 & 226000 & $\mid 1035100$ & 0 & 39780 & 421200 & 1731080 \\
\hline Trade & Use & 2249019 & 0 & 3374433 & 2496164 & 2619737 & 1250414 & 0 & 0 & 5628259 & 0 & 10280179 & 0 & 2820594 & 0 & 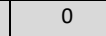 & 2948066 & 18689563 & 0 & 1132767 & 9746532 & 63235727 \\
\hline Trade & Exports & 1049987 & 0 & 1574958 & 1165370 & 1223062 & 583726 & 0 & 0 & 0 & 0 & 1887892 & 0 & -33878 & 0 & 促 & 0 & 0 & 0 & -212261 & 0 & 7238857 \\
\hline Trade & Source-separation & 290772 & 0 & 436236 & 322725 & 338702 & 161660 & 0 & 0 & 410645 & 0 & 735504 & 0 & 205867 & 0 & 0 & 170672 & 1328831 & 0 & 66291 & 701907 & 5169811 \\
\hline Use & Source-separation & 2249019 & 0 & 3374433 & 2496164 & 2619737 & 1250414 & 0 & 0 & 4999660 & 0 & 5712424 & 0 & 1113751 & 0 & 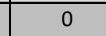 & 2289721 & 15367883 & 0 & 915235 & 7890554 & 50278996 \\
\hline Use & Stock & 0 & 0 & 0 & 0 & 0 & 0 & 0 & 0 & 628598 & 0 & 4567755 & 0 & 1706843 & 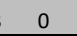 & 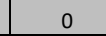 & 658344 & 3321680 & 0 & 217532 & 1855978 & 12956731 \\
\hline Source-separation & Separate collection & 1563068 & 0 & 0 & 1734834 & 1173642 & 0 & 0 & 0 & 2999796 & 0 & 0 & 0 & 779626 & 0 & 0 & 789954 & 7683942 & 0 & 284638 & 2453962 & 19463463 \\
\hline Source-separation & Prod_con_w & 290772 & 0 & 436236 & 322725 & 338702 & 161660 & 0 & 0 & 410645 & 0 & 735504 & 0 & 205867 & 0 & 0 & 170672 & $\mid 1328831$ & 0 & 66291 & 701907 & 5169811 \\
\hline Source-separation & Residual collection & 685951 & 0 & 3374433 & 761330 & 1446095 & 1250414 & 0 & 0 & 1999864 & O & 5712424 & 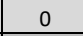 & 334125 & 0 & 0 & 1499767 & 7683942 & 0 & 630597 & 5436592 & 30815534 \\
\hline Separate collection & Exports & 255650 & 0 & 0 & 283744 & 191957 & 0 & 0 & 0 & 11162 & 0 & 0 & 0 & 0 & 0 & 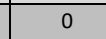 & 30 & 140892 & 0 & 1059 & 9131 & 893626 \\
\hline Separate collection & Plastic sorting & 1307418 & 0 & 0 & 1451090 & 981685 & 0 & 0 & 0 & 2988634 & 0 & 0 & 0 & 779626 & 0 & 0 & 789924 & 7543049 & 0 & 283579 & 2444831 & 18569837 \\
\hline Plastic sorting & Incineration & 236815 & 0 & 0 & 262839 & 177815 & 0 & 0 & 0 & 541338 & 0 & 0 & 0 & 152743 & 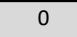 & 0 & 143081 & 1366288 & 0 & 51365 & 442837 & 3375121 \\
\hline Plastic sorting & Landfill & 155410 & 0 & 0 & 172488 & 116691 & 0 & 0 & 0 & 355253 & 0 & 0 & 0 & 81145 & 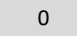 & 0 & 93897 & 896627 & 0 & 33708 & 290612 & 2195830 \\
\hline Prod_con_w & Prod_con_w & 290772 & 0 & 436236 & 322725 & 338702 & 161660 & 0 & 0 & 410645 & 0 & 735504 & 0 & 205867 & 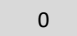 & c & 170672 & 1328831 & 0 & 66291 & 701907 & 5169811 \\
\hline Plastic sorting & Recycling & 915193 & 0 & 0 & 1015763 & 687179 & 0 & 0 & 0 & 2092044 & 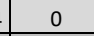 & 0 & 0 & 545738 & 0 & 0 & 552947 & 5280135 & 0 & 198505 & 1711382 & 12998886 \\
\hline Residual collection & Incineration & 411571 & 0 & 2024660 & 456798 & 867657 & 750248 & 0 & 0 & | 1199918 & 0 & 5141182 & 0 & 218204 & 0 & c & 899860 & \begin{tabular}{|l|}
4639361 \\
\end{tabular} & 0 & 378358 & 3261955 & 20249773 \\
\hline Residual collection & Landfill & 274380 & 0 & 349773 & 304532 & 578438 & 500165 & 0 & 0 & 799946 & 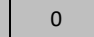 & 571242 & 0 & 115921 & 0 & c & 599907 & 3044581 & 0 & 252239 & 2174637 & 10565761 \\
\hline Residual collection & Recycling & 0 & 0 & 0 & 0 & 0 & 0 & 0 & 0 & 0 & 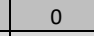 & 0 & 0 & 0 & 0 & 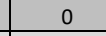 & 0 & 0 & 0 & 0 & 0 & 0 \\
\hline Recycling & Recycled raw mater & 0 & 0 & 0 & 0 & 0 & 0 & 0 & 0 & 1757317 & 0 & 0 & 0 & 229210 & 0 & 0 & 464475 & 4435313 & 0 & 549808 & 3482940 & 10919064 \\
\hline Recycling & In & 88411 & 0 & 0 & 98127 & 66384 & 0 & 0 & 0 & 202099 & 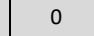 & 0 & 0 & 57024 & 0 & 0 & 53417 & 844822 & 0 & 19176 & 165326 & 1594786 \\
\hline Recycling & Landfill & 58020 & 0 & 0 & 64396 & 43565 & 0 & 0 & 0 & 132628 & 0 & 0 & 0 & 30294 & 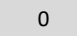 & 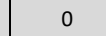 & 35055 & 0 & 0 & 12584 & 108495 & 485036 \\
\hline Prod_con_w & Prod_con_w & 399069 & 0 & 627109 & 442923 & 464850 & 232425 & 0 & 0 & 257256 & 0 & 460768 & 0 & 340439 & 0 & 0 & 177341 & 871463 & 0 & 77334 & 818833 & 5169811 \\
\hline
\end{tabular}


S5.8 All initiatives, increasing demand (S5a)
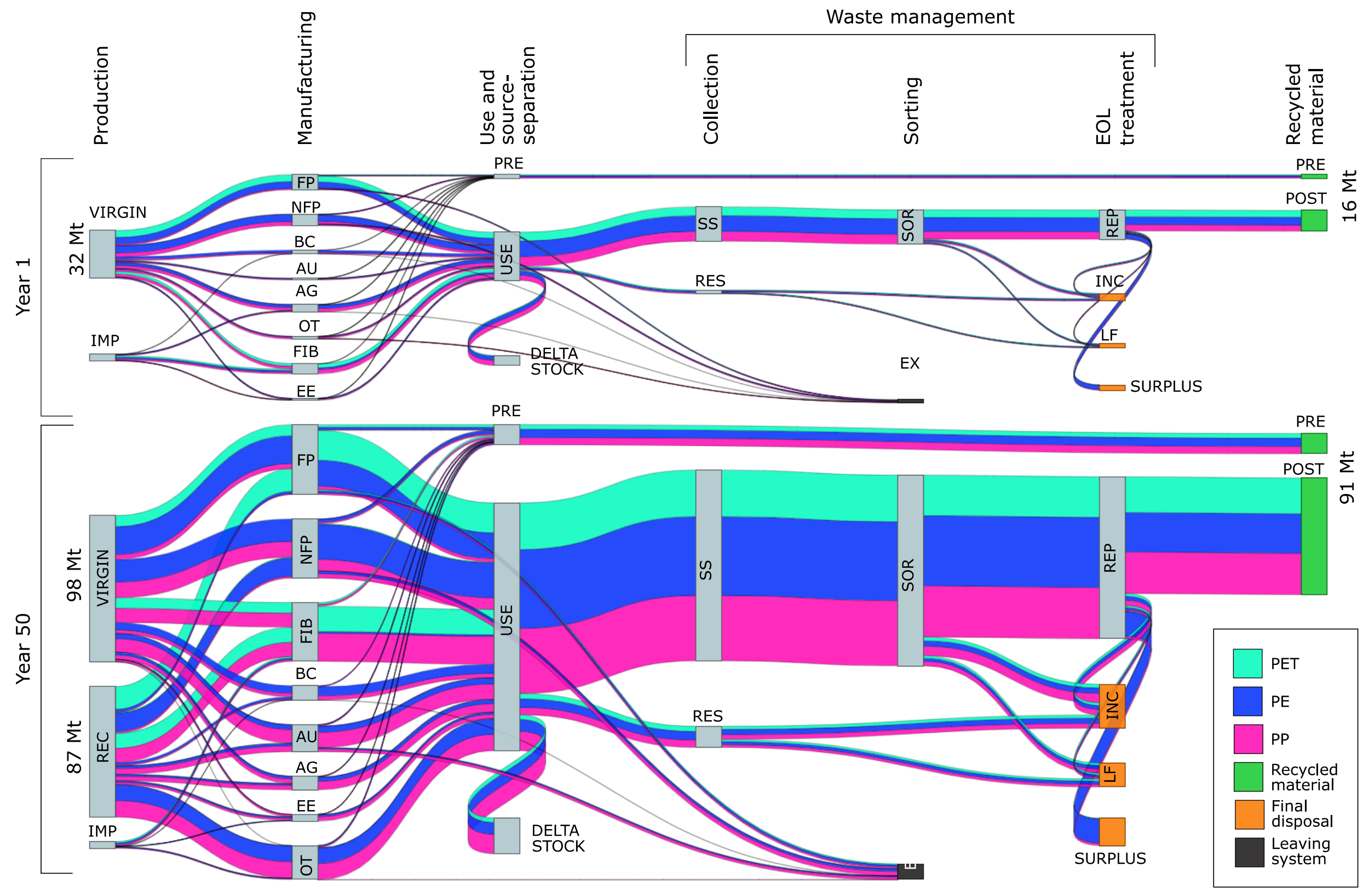

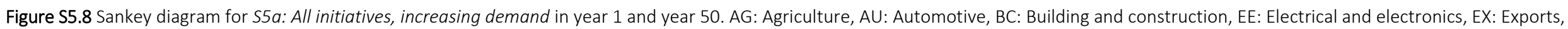

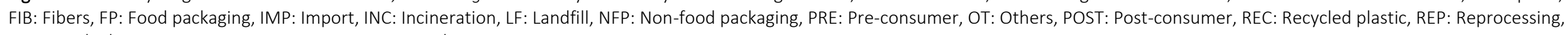
RES: Residual waste, SOR: Sorting, SS: Source-separated waste. 
Table S5.43 Detailed PET flow values [ton] in year 1 in S5a: All initiatives, increasing demand. Prod_con_w: Pre-consumer waste. Flow abbreviations are provided in Table S1.1 and on page 53.

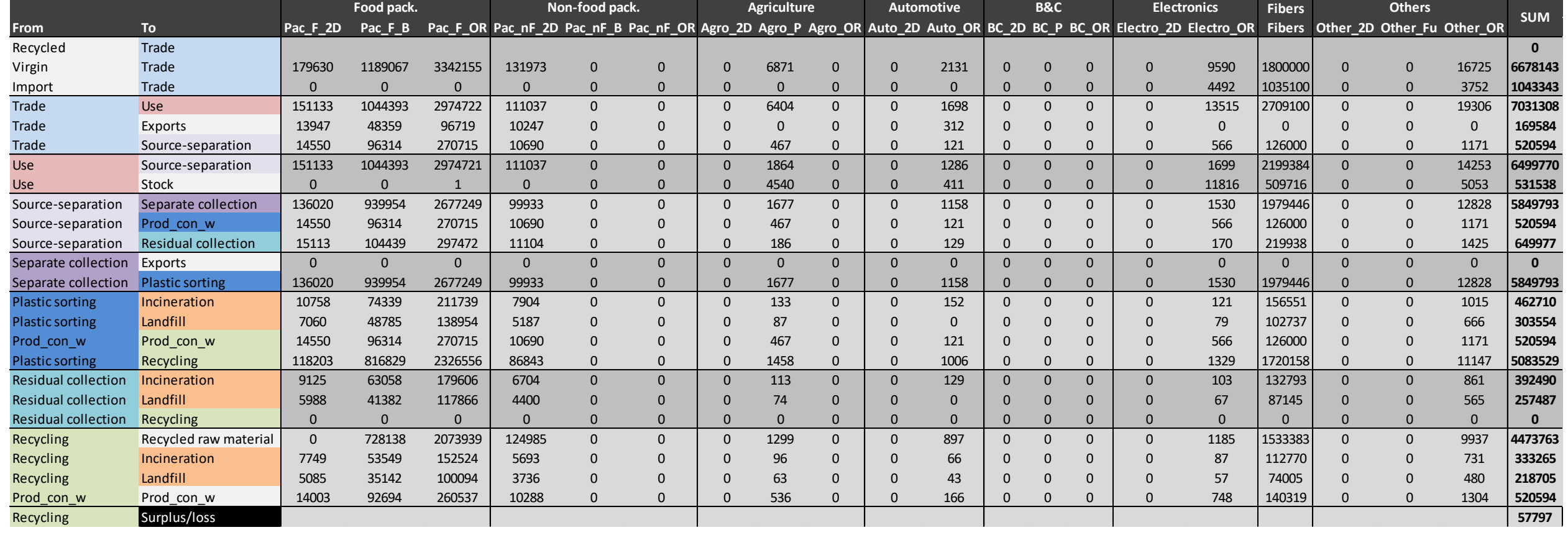

Table S5.44 Detailed PET flow values [ton] in year 50 in S5a: All initiatives, increasing demand. Prod_con_w: Pre-consumer waste. Flow abbreviations are provided in Table S1.1 and on page 53.

\begin{tabular}{|c|c|c|c|c|c|c|c|c|c|c|c|c|c|c|c|c|c|c|c|c|c|c|}
\hline \multirow[b]{2}{*}{ From } & \multirow[b]{2}{*}{ To } & \multicolumn{3}{|c|}{ Food pack. } & \multicolumn{3}{|c|}{ Non-food pack. } & \multirow{2}{*}{\multicolumn{3}{|c|}{ Agriculture }} & \multirow{2}{*}{\multicolumn{2}{|c|}{$\begin{array}{c}\text { Automotive } \\
\text { Auto_2D Auto_OR }\end{array}$}} & \multirow{2}{*}{ BC_2D } & \multirow{2}{*}{\multicolumn{2}{|c|}{$\begin{array}{l}B \& C \\
B C P B C \text { OR }\end{array}$}} & \multirow{2}{*}{\multicolumn{2}{|c|}{$\begin{array}{c}\text { Electronics } \\
\text { R Electro_2D Electro_OR }\end{array}$}} & \multirow{2}{*}{\begin{tabular}{|l|} 
Fibers \\
Fibers
\end{tabular}} & \multirow{2}{*}{\multicolumn{3}{|c|}{$\begin{array}{c}\text { Others } \\
\text { Other 2D Other Fu Other OR }\end{array}$}} & \multirow{2}{*}{ SUM } \\
\hline & & Pac_F_2D & Pac_F_B & Pac_F_OR & Pac_nF_2D & Pac_nF_B & B Pac_nF_OR & & & Agro_OR & & & & & & & & & & & & \\
\hline Recycled & Trade & 79544 & 2746332 & 12412096 & 431749 & 0 & 0 & 0 & 40609 & 0 & 0 & 7173 & 0 & 0 & 0 & 0 & 34905 & 10100199 & 0 & 0 & 54781 & 25907389 \\
\hline Virgin & Trade & 508115 & 965637 & 5839249 & 0 & 0 & 0 & 0 & 27663 & 0 & 0 & 14001 & 0 & 0 & 0 & 0 & 22542 & 6984765 & 0 & 0 & 34464 & 14396435 \\
\hline Import & Trade & 0 & 0 & 0 & 0 & 0 & 0 & 0 & 0 & 0 & 0 & 0 & 0 & 0 & 0 & 0 & 4492 & 1035100 & 0 & 0 & 3752 & 1043343 \\
\hline Trade & Exports & 45628 & 150966 & 528176 & 33522 & 0 & 0 & 0 & 0 & 0 & 0 & 3099 & 0 & 0 & 0 & 0 & 0 & 0 & 0 & 0 & 0 & 761391 \\
\hline Trade & Source-separation & 47600 & 300669 & 1478359 & 34972 & 0 & 0 & 0 & 4643 & 0 & 0 & 1207 & 0 & 0 & 0 & 0 & 3389 & 1195947 & 0 & 0 & 6247 & 3073034 \\
\hline Use & Source-separation & 494431 & 3260334 & 16244810 & 363255 & 0 & 0 & 0 & 56523 & 0 & 0 & 9373 & 0 & 0 & 0 & 0 & 45475 & 13934605 & 0 & 0 & 70231 & 34479037 \\
\hline Use & Stock & 0 & 0 & 0 & 0 & 0 & 0 & 0 & 7107 & 0 & 0 & 7495 & 0 & 0 & 0 & 0 & 13074 & 2989512 & 0 & 0 & 16519 & 3033706 \\
\hline Source-separation & Separate collection & 444987 & 2934300 & 14620329 & 326930 & 0 & 0 & 0 & 50871 & 0 & 0 & 8436 & 0 & 0 & 0 & 0 & 40928 & 12541145 & 0 & 0 & 63208 & 31031133 \\
\hline Source-separation & Residual collection & 49443 & 326033 & 1624481 & 36326 & 0 & 0 & 0 & 5652 & 0 & 0 & 937 & 0 & 0 & 0 & 0 & 4548 & 1393461 & 0 & 0 & 7023 & 3447904 \\
\hline Separate collection & Exports & 0 & 0 & 0 & 0 & 0 & 0 & 0 & 0 & 0 & 0 & 0 & 0 & 0 & 0 & 0 & 0 & 0 & 0 & 0 & 0 & 0 \\
\hline Separate collection & Plastic sorting & 444987 & 2934300 & 14620329 & 326930 & 0 & 0 & 0 & 50871 & 0 & 0 & 8436 & 0 & 0 & 0 & 0 & 40928 & 12541145 & 0 & 0 & 63208 & 31031133 \\
\hline Plastic sorting & Incineration & 35193 & 232069 & 1156297 & 25856 & 0 & 0 & 0 & 4023 & 0 & 0 & 1105 & 0 & 0 & 0 & 0 & 3237 & 991858 & 0 & 0 & 4999 & 2454637 \\
\hline Plastic sorting & Landfill & 23096 & 152295 & 758820 & 16968 & 0 & 0 & 0 & 2640 & 0 & 0 & 0 & 0 & 0 & 0 & 0 & 2124 & 650907 & 0 & 0 & 3281 & 1610131 \\
\hline Prod_con_w & Prod_con_w & 47600 & 300669 & 1478359 & 34972 & 0 & 0 & 0 & 4643 & 0 & 0 & 1207 & 0 & 0 & 0 & 0 & 3389 & 1195947 & 0 & 0 & 6247 & 3073034 \\
\hline Plastic sorting & Recycling & 386699 & 2549936 & 12705212 & 284105 & 0 & 0 & 0 & 44207 & 0 & 0 & 7331 & 0 & 0 & 0 & 0 & 35567 & 10898380 & 0 & 0 & 54928 & 26966365 \\
\hline Residual collection & Incineration & 29852 & 196850 & 980819 & 21932 & 0 & 0 & 0 & 3413 & 0 & 0 & 937 & 0 & 0 & 0 & 0 & 2746 & 841335 & 0 & 0 & 4240 & 2082125 \\
\hline Residual collection & Landfill & 19591 & 129183 & 643662 & 14393 & 0 & 0 & 0 & 2240 & 0 & 0 & 0 & 0 & 0 & 0 & 0 & 1802 & 552126 & 0 & 0 & 2783 & 1365779 \\
\hline Residual collection & Recycling & 0 & 0 & 0 & 0 & 0 & 0 & 0 & 0 & 0 & 0 & 0 & 0 & 0 & 0 & 0 & 0 & 0 & 0 & 0 & 0 & 0 \\
\hline Recycling & Landfill & 16637 & 109704 & 546607 & 12223 & 0 & 0 & 0 & 1902 & 0 & 0 & 315 & 0 & 0 & 0 & 0 & 1530 & 468873 & 0 & 0 & 2363 & 1160154 \\
\hline Prod_con_w & Prod_con_w & 82659 & 547165 & 1537936 & 60729 & 0 & 0 & 0 & 3162 & 0 & 0 & 981 & 0 & 0 & 0 & 0 & 4413 & 828293 & 0 & 0 & 7696 & 3073034 \\
\hline Recycling & Surplus/loss & & & & & & & & & & & & & & & & & & & & & 216154 \\
\hline
\end{tabular}




\begin{tabular}{|c|c|c|c|c|c|c|c|c|c|c|c|c|c|c|c|c|c|c|c|c|c|c|}
\hline From & To & Pac_F_2D & $\begin{array}{l}\text { Food pack. } \\
\text { Pac_F_B }\end{array}$ & Pac_F_OR & \begin{tabular}{|l} 
No \\
Pac_nF_2D
\end{tabular} & $\begin{array}{l}\text { on-food pa } \\
\text { Pac_nF_B }\end{array}$ & $\begin{array}{l}\text { k. } \\
\text { Pac_nF_OR }\end{array}$ & Agro_2D & $\begin{array}{l}\text { Agricultur } \\
\text { Agro_P }\end{array}$ & $\begin{array}{l}\text { e } \\
\text { Agro_OR }\end{array}$ & $\begin{array}{r}\text { Auto } \\
\text { Auto_2D }\end{array}$ & $\begin{array}{l}\text { notive } \\
\text { Auto_OR }\end{array}$ & BC_2D & $\begin{array}{l}B \& C \\
B C \_P\end{array}$ & BC_OR & $\begin{array}{r}\text { Elec } \\
\text { Electro_2D }\end{array}$ & $\begin{array}{l}\text { onics } \\
\text { Electro_OR }\end{array}$ & \begin{tabular}{l|} 
Fibers \\
Fibers
\end{tabular} & Other_2D & $\begin{array}{l}\text { Others } \\
\text { Other_Fu }\end{array}$ & Other_OR & SUM \\
\hline Recycled & Trade & & & & & & & & & & & & & & & & & & & & & 0 \\
\hline Virgin & Trade & 4497128 & 0 & 0 & 2407793 & 2432720 & 118994 & 365360 & 77688 & 60790 & 0 & 517785 & 548048 & 1201236 & 0 & 0 & 421489 & 0 & 0 & 255741 & 1742712 & 14647486 \\
\hline Import & Trade & 0 & 0 & 0 & 0 & 0 & 0 & 0 & 0 & 0 & 0 & 0 & 6579 & 14421 & 0 & 0 & 197000 & 1035100 & 0 & 57378 & 390998 & 1701477 \\
\hline Trade & Use & 3797268 & 0 & 0 & 2033083 & 2104276 & 100476 & 340516 & 72405 & 56656 & 0 & 412484 & 516812 & 1132772 & 0 & 0 & 593621 & 1035100 & 0 & 295217 & 2011721 & 14502408 \\
\hline Trade & Exports & 335593 & 0 & 0 & 179679 & 131394 & 8880 & 0 & 0 & 0 & 0 & 75787 & 0 & 0 & 0 & 0 & 0 & 0 & 0 & 0 & 0 & 731333 \\
\hline Trade & Source-separation & 364267 & 0 & 0 & 195031 & 197050 & 9639 & 24844 & 5283 & 4134 & 0 & 29514 & 37815 & 82885 & 0 & 0 & 24868 & 0 & 0 & 17902 & 121990 & 1115222 \\
\hline Use & Source-separation & 3797267 & 0 & 0 & 2033083 & 2104275 & 100476 & 303062 & 65499 & 49178 & 0 & 177242 & 20233 & 45036 & 0 & 0 & 304765 & 840346 & 0 & 237430 & 1679990 & 11757882 \\
\hline Use & Stock & 1 & 0 & 0 & 1 & 1 & 0 & 37454 & 6906 & 7479 & 0 & 235242 & 496579 & 1087736 & 0 & 0 & 288856 & 194754 & 0 & 57787 & 331731 & 2744526 \\
\hline Source-separation & Separate collection & 3417540 & 0 & 0 & 1829774 & 1893848 & 90428 & 272755 & 58949 & 44260 & 0 & 159518 & 18210 & 40532 & 0 & 0 & 274289 & 756312 & 0 & 213687 & 1511991 & 10582094 \\
\hline Source-separation & Prod_con_w & 364267 & 0 & 0 & 195031 & 197050 & 9639 & 24844 & 5283 & 4134 & 0 & 29514 & 37815 & 82885 & 0 & 0 & 24868 & 0 & 0 & 17902 & 121990 & 1115222 \\
\hline Source-separation & Residual collection & 379727 & 0 & 0 & 203308 & 210428 & 10048 & 30306 & 6550 & 4918 & 0 & 17724 & 2023 & 4504 & 0 & 0 & 30477 & 84035 & 0 & 23743 & 167999 & 1175788 \\
\hline Separate collection & Exports & 0 & 0 & 0 & 0 & 0 & 0 & 0 & 0 & 0 & 0 & 0 & 0 & 0 & 0 & 0 & 0 & 0 & 0 & 0 & 0 & 0 \\
\hline Separate collection & Plastic sorting & 3417540 & 0 & 0 & 1829774 & 1893848 & 90428 & 272755 & 58949 & 44260 & 0 & 159518 & 18210 & 40532 & 0 & 0 & 274289 & 756312 & 0 & 213687 & 1511991 & 10582094 \\
\hline Plastic sorting & Incineration & 225821 & 0 & 0 & 120906 & 125140 & 5975 & 18023 & 3895 & 2925 & 0 & 17458 & 1443 & 2862 & 0 & 0 & 18124 & 82771 & 0 & 14120 & 99908 & 739369 \\
\hline Plastic sorting & Landfill & 148195 & 0 & 0 & 79345 & 82123 & 3921 & 11827 & 2556 & 1919 & 0 & 0 & 550 & 1574 & 0 & 0 & 11894 & 0 & 0 & 9266 & 65564 & 418735 \\
\hline Prod_con_w & Prod_con_w & 364267 & 0 & 0 & 195031 & 197050 & 9639 & 24844 & 5283 & 4134 & 0 & 29514 & 37815 & 82885 & 0 & 0 & 24868 & 0 & 0 & 17902 & 121990 & 1115222 \\
\hline Plastic sorting & Recycling & 3043525 & 0 & 0 & 1629524 & 1686585 & 80532 & 242905 & 52498 & 39416 & 0 & 142060 & 16217 & 36096 & 0 & 0 & 244271 & 673541 & 0 & 190301 & 1346518 & 9423989 \\
\hline Residual collection & Incineration & 227836 & 0 & 0 & 121985 & 126257 & 6029 & 18184 & 3930 & 2951 & 0 & 15952 & 1465 & 2906 & 0 & 0 & 18286 & 84035 & 0 & 14246 & 100799 & 744859 \\
\hline Residual collection & Landfill & 151891 & 0 & 0 & 81323 & 84171 & 4019 & 12122 & 2620 & 1967 & 0 & 1772 & 558 & 1598 & 0 & 0 & 12191 & 0 & 0 & 9497 & 67200 & 430930 \\
\hline Residual collection & Recycling & 0 & 0 & 0 & 0 & 0 & 0 & 0 & 0 & 0 & 0 & 0 & 0 & 0 & 0 & 0 & 0 & 0 & 0 & 0 & 0 & 0 \\
\hline Recycling & Recycled raw material & 0 & 0 & 0 & 1307582 & 766974 & 0 & 85956 & 47747 & 35849 & 0 & 129204 & 7375 & 16415 & 0 & 0 & 222164 & 612586 & 0 & 284189 & 1936571 & 5452611 \\
\hline Recycling & Landfill & 109136 & 0 & 0 & 58432 & 60478 & 2888 & 8710 & 1882 & 1413 & 0 & 0 & 405 & 1159 & 0 & 0 & 8759 & 0 & 0 & 6824 & 48284 & 308372 \\
\hline Prod_con_w & Prod_con_w & 342400 & 0 & 0 & 183323 & 185221 & 9060 & 27818 & 5915 & 4628 & 0 & 39423 & 41727 & 91459 & 0 & 0 & 32091 & 0 & 0 & 19471 & 132686 & 1115222 \\
\hline Recycling & Surplus/loss & & & & & & & & & & & & & & & & & & & & & 3118507 \\
\hline
\end{tabular}

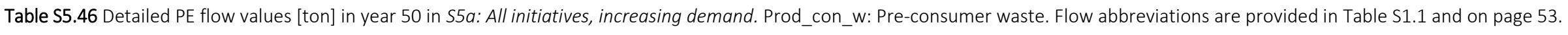

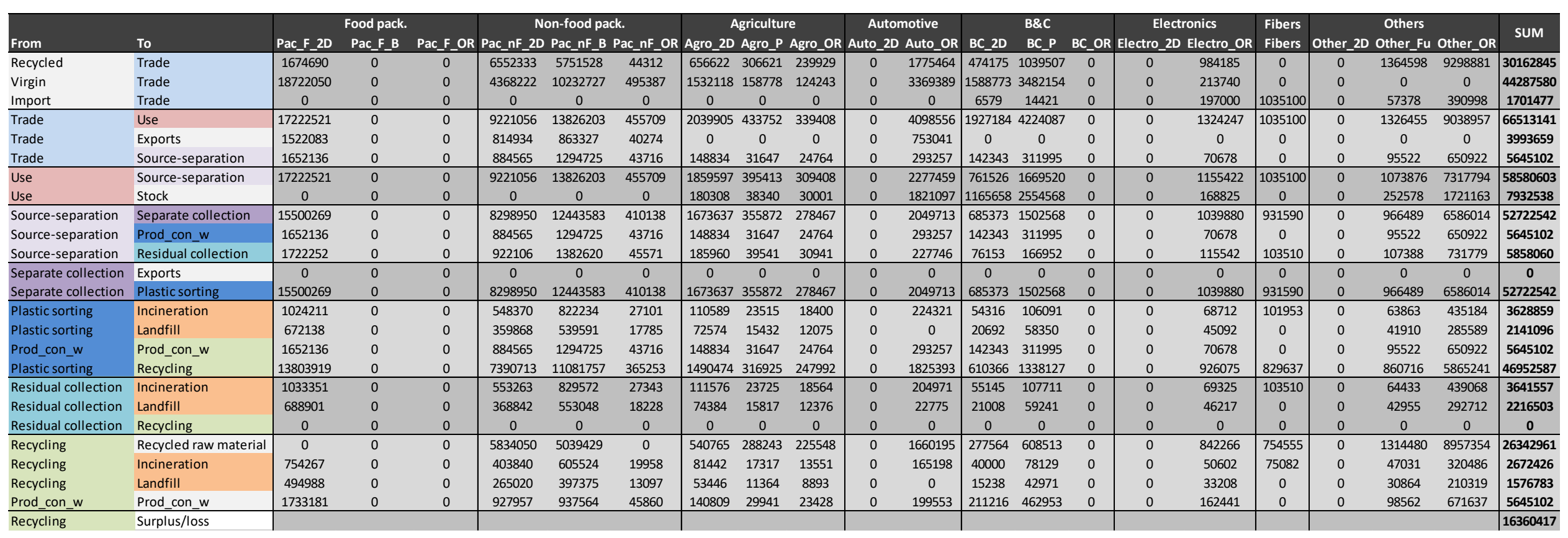




\begin{tabular}{|c|c|c|c|c|c|c|c|c|c|c|c|c|c|c|c|c|c|c|c|c|c|c|}
\hline & & & Food pack. & & & on-food p & & & Agricultur & & & motive & & $B \& C$ & & Elect & ronics & Fibers & & Others & & SUM \\
\hline From & To & Pac_F_2D & Pac_F_B & Pac_F_OR & Pac_nF_2D & Pac_nF_B & Pac_nF_OR & Agro_2D & Agro_P & Agro_OR & Auto_2 & Auto_OR & BC_2D & BC_P & BC_OR & Electro_2D & Electro_OR & Fibers & Other_2D & Other_Fu & Other_OR & \\
\hline Recycled & Trade & & & & & & & & & & & & & & & & & & & & & 0 \\
\hline Virgin & Trade & 791484 & 0 & 0 & 878460 & 921948 & 780000 & 0 & 0 & 607764 & 0 & 1298633 & 0 & 792627 & 0 & 0 & $482876 \quad 2$ & 2000000 & 0 & 177481 & 1879215 & 10610489 \\
\hline Import & Trade & 0 & 0 & 0 & 0 & 0 & 0 & 0 & 0 & 0 & 0 & 0 & 0 & 9000 & 0 & 0 & 226000 & 1035100 & 0 & 39780 & 421200 & 1731080 \\
\hline Trade & Use & 495870 & 0 & 0 & 550361 & 577607 & 581988 & 0 & 0 & 566436 & 0 & 1034611 & 0 & 755936 & 0 & 0 & 680387 & 2895100 & 0 & 244618 & 2168870 & 10551782 \\
\hline Trade & Exports & 231504 & 0 & 0 & 256944 & 269664 & 134832 & 0 & 0 & 0 & 0 & 190000 & 0 & -9000 & 0 & 0 & 0 & 0 & 0 & -39780 & 0 & 1034164 \\
\hline Trade & Source-separation & 64110 & 0 & 0 & 71155 & 74678 & 63180 & 0 & 0 & 41328 & 0 & 74022 & 0 & 54691 & 0 & 0 & 28490 & 140000 & 0 & 12424 & 131545 & 755623 \\
\hline Use & Source-separation & 495870 & 0 & 0 & 550361 & 577606 & 581988 & 295315 & 63852 & 60775 & 0 & 593697 & 0 & 28755 & 0 & 0 & 304786 & 1610775 & 0 & 236279 & 1683565 & 7083624 \\
\hline Use & Stock & 0 & 0 & 0 & 0 & 0 & 0 & -295315 & -63852 & 505660 & 0 & 440914 & 0 & 727180 & 0 & 0 & \begin{tabular}{l|l}
375601 & 1
\end{tabular} & 1284325 & 0 & 8339 & 485305 & 3468158 \\
\hline Source-separation & Separate collection & 446283 & 0 & 0 & 495325 & 519846 & 523789 & 265783 & 57467 & 54698 & 0 & 534328 & 0 & 25880 & 0 & 0 & 274307 & 1449698 & 0 & 212651 & 1515208 & 6375262 \\
\hline Source-separation & Residual collection & 49587 & 0 & 0 & 55036 & 57761 & 58199 & 29531 & 6385 & 6078 & 0 & 59370 & 0 & 2876 & 0 & 0 & 30479 & 161078 & 0 & 23628 & 168356 & 708362 \\
\hline Separate collection & Exports & 0 & 0 & 0 & 0 & 0 & 0 & 0 & 0 & 0 & 0 & 0 & 0 & 0 & 0 & 0 & 0 & 0 & 0 & 0 & 0 & 0 \\
\hline Separate collection & Plastic sorting & 446283 & 0 & 0 & 495325 & 519846 & 523789 & 265783 & 57467 & 54698 & 0 & 534328 & 0 & 25880 & 0 & 0 & 274307 & 1449698 & 0 & 212651 & 1515208 & 6375262 \\
\hline Plastic sorting & Incineration & 58391 & 0 & 0 & 64807 & 68015 & 113505 & 34774 & 7519 & 7157 & 0 & 115789 & 0 & 3380 & 0 & 0 & 35890 & \begin{tabular}{|l|}
189675 \\
\end{tabular} & 0 & 27823 & 198246 & \begin{tabular}{|l|}
924971 \\
\end{tabular} \\
\hline Plastic sorting & Landfill & 38319 & 0 & 0 & 42530 & 44635 & 0 & 22821 & 4934 & 4696 & 0 & 0 & 0 & 1796 & 0 & 0 & 23553 & 124474 & 0 & 18259 & 130099 & 456116 \\
\hline Prod_con_w & Prod_con_w & 64110 & 0 & 0 & 71155 & 74678 & 63180 & 0 & 0 & 41328 & 0 & 74022 & 0 & 54691 & 0 & 0 & 28490 & 140000 & 0 & 12424 & 131545 & 755623 \\
\hline Plastic sorting & Recycling & 349573 & 0 & 0 & 387988 & 407195 & 410284 & 208188 & 45014 & 42845 & 0 & 418539 & 0 & 20704 & 0 & 0 & 214865 & 1135548 & 0 & 166570 & 1186863 & 4994175 \\
\hline Residual collection & Incineration & 29752 & 0 & 0 & 33022 & 34656 & 34919 & 17719 & 3831 & 3647 & 0 & 53433 & 0 & 1878 & 0 & 0 & 18287 & 97254 & 0 & 14177 & 101014 & 443589 \\
\hline Residual collection & Landfill & 19835 & 0 & 0 & 22014 & 23104 & 23280 & 11813 & 2554 & 2431 & 0 & 5937 & 0 & 998 & 0 & 0 & 12191 & 63823 & 0 & 9451 & 67343 & 264774 \\
\hline Residual collection & Recycling & 0 & 0 & 0 & 0 & 0 & 0 & 0 & 0 & 0 & 0 & 0 & 0 & 0 & 0 & 0 & 0 & 0 & 0 & 0 & 0 & 0 \\
\hline Recycling & Recycled raw material & 0 & 0 & 0 & 59627 & 0 & 0 & 0 & 0 & 36817 & 0 & 359659 & 0 & 8896 & 0 & 0 & 184638 & 975799 & 0 & 239250 & 2097084 & 3961771 \\
\hline Recycling & Landfill & 19486 & 0 & 0 & 21627 & 22698 & 22870 & 11610 & 2509 & 2388 & 0 & 0 & 0 & 1010 & 0 & 0 & 11977 & 0 & 0 & 9285 & 66157 & 191616 \\
\hline Prod_con_w & Prod_con_w & 56365 & 0 & 0 & 62559 & 65656 & 55547 & 0 & 0 & 43282 & 0 & 92482 & 0 & 56447 & 0 & 0 & 34388 & 142429 & 0 & 12639 & 133828 & 755623 \\
\hline Recycling & Surplus/loss & & & & & & & & & & & & & & & & & & & & & 329811 \\
\hline
\end{tabular}

Table S5.48 Detailed PP flow values [ton] in year 50 in S5a: All initiatives, increasing demand. Prod_con_w: Pre-consumer waste. Flow abbreviations are provided in Table S1.1 and on page 53.

\begin{tabular}{|c|c|c|c|c|c|c|c|c|c|c|c|c|c|c|c|c|c|c|c|c|c|c|}
\hline \multirow[b]{2}{*}{ From } & \multirow[b]{2}{*}{ To } & \multicolumn{3}{|c|}{ Food pack. } & \multicolumn{3}{|c|}{ Non-food pack. } & \multicolumn{3}{|c|}{ Agriculture } & \multirow{2}{*}{\multicolumn{2}{|c|}{$\begin{array}{c}\text { Automotive } \\
\text { Auto_2D Auto_OR }\end{array}$}} & \multicolumn{3}{|c|}{ B\&C } & \multicolumn{2}{|c|}{ Electronics } & \multirow{2}{*}{\begin{tabular}{|l} 
Fibers \\
Fibers
\end{tabular}} & \multirow{2}{*}{\multicolumn{3}{|c|}{ Others }} & \multirow[b]{2}{*}{ SUM } \\
\hline & & Pac_F_2D & Pac_F_B & Pac_F_OR & Pac_nF_2D & Pac_nF_B & Pac_nF_OR & Agro_2D & Agro_t & P Agro_OR & & & BC_2D & BC_P & BC_OR & Electro_2D & Electro_OR & & & & & \\
\hline Recycled & Trade & 347245 & 0 & 0 & 385403 & 404483 & 342206 & 0 & 0 & 3019452 & 0 & 3868655 & 0 & 682959 & 0 & 0 & 1474033 & \begin{tabular}{|l|}
9491647 \\
\end{tabular} & 0 & 947017 & 10027239 & 30990338 \\
\hline Virgin & Trade & 3242534 & 0 & 0 & 3598856 & 3777017 & 3034634 & 0 & 0 & 3019452 & 0 & 9034920 & 0 & 2300625 & 0 & 0 & 1418704 & \begin{tabular}{|l|l|} 
& 9491647 \\
\end{tabular} & 0 & 0 & 0 & 38918390 \\
\hline Import & Trade & 0 & 0 & 0 & 0 & 0 & 0 & 0 & 0 & 0 & 0 & 0 & 0 & 9000 & 0 & 0 & 226000 & $\mid 1035100$ & 0 & 39780 & 421200 & 1731080 \\
\hline Trade & Exports & 1049987 & 0 & 0 & 1165370 & 1223062 & 583726 & 0 & 0 & 0 & 0 & 1887892 & 0 & -33878 & 0 & 0 & 0 & 0 & 0 & -212261 & 0 & 5663898 \\
\hline Trade & Source-separation & 290772 & 0 & 0 & 322725 & 338702 & 273524 & 0 & 0 & 410645 & 0 & 735504 & 0 & 205867 & 0 & 0 & 170672 & 1328831 & 0 & 66291 & 701907 & 4845439 \\
\hline Use & Source-separation & 2249019 & 0 & 0 & 2496164 & 2619737 & 2519590 & 0 & 0 & 4999660 & 0 & 5712424 & 0 & 1113751 & 0 & 0 & 2289721 & 15367883 & 0 & 915235 & 7890554 & 48173740 \\
\hline Use & Stock & 0 & 0 & 0 & 0 & 0 & 0 & 0 & 0 & 628598 & 0 & 4567755 & 0 & 1706843 & 0 & 0 & 658344 & \begin{tabular}{|l|}
3321680 \\
\end{tabular} & 0 & 217532 & 1855978 & 12956731 \\
\hline Source-separation & Separate collection & 2024117 & 0 & 0 & 2246548 & 2357763 & 2267631 & 0 & 0 & 4499694 & 0 & 5141182 & 0 & 1002376 & 0 & 0 & 2060749 & 13831095 & 0 & 823711 & 7101499 & 43356366 \\
\hline Source-separation & Residual collection & 224902 & 0 & 0 & 249616 & 261974 & 251959 & 0 & 0 & 499966 & 0 & 571242 & 0 & 111375 & 0 & 0 & 228972 & 1536788 & 0 & 91523 & 789055 & 4817374 \\
\hline Separate collection & Exports & 0 & 0 & 0 & 0 & 0 & 0 & 0 & 0 & 0 & 0 & 0 & 0 & 0 & 0 & 0 & 0 & 0 & 0 & 0 & 0 & 0 \\
\hline Separate collection & Plastic sorting & 2024117 & 0 & 0 & 2246548 & 2357763 & 2267631 & 0 & 0 & 4499694 & 0 & 5141182 & 0 & 1002376 & 0 & 0 & 2060749 & 13831095 & 0 & 823711 & 7101499 & 43356366 \\
\hline Plastic sorting & Incineration & 264831 & 0 & 0 & 293933 & 308484 & 491396 & 0 & 0 & 588730 & 0 & 1114094 & 0 & 130923 & 0 & 0 & 269624 & \begin{tabular}{|l|}
1809629 \\
\end{tabular} & 0 & 107772 & 929144 & 6308560 \\
\hline Plastic sorting & Landfill & 173795 & 0 & 0 & 192894 & 202443 & 0 & 0 & 0 & 386354 & 0 & 0 & 0 & 69553 & 0 & 0 & 176941 & $\mid 1187569$ & 0 & 70726 & 609751 & 3070025 \\
\hline Prod_con_w & Prod_con_w & 290772 & 0 & 0 & 322725 & 338702 & 273524 & 0 & 0 & 410645 & 0 & 735504 & 0 & 205867 & 0 & 0 & 170672 & $\mid 1328831$ & 0 & 66291 & 701907 & 4845439 \\
\hline Plastic sorting & Recycling & 1585491 & 0 & 0 & 1759721 & 1846836 & 1776236 & 0 & 0 & 3524611 & 0 & 4027088 & 0 & 801901 & 0 & 0 & 1614185 & 10833897 & 0 & 645213 & 5562604 & 33977781 \\
\hline Residual collection & Incineration & 134941 & 0 & 0 & 149770 & 157184 & 151175 & 0 & 0 & 299980 & 0 & 514118 & 0 & 72735 & 0 & 0 & 137383 & \begin{tabular}{|l|}
927872 \\
\end{tabular} & 0 & 54914 & 473433 & 3073506 \\
\hline Residual collection & Landfill & 89961 & 0 & 0 & 99847 & 104789 & 100784 & 0 & 0 & 199986 & 0 & 57124 & 0 & 38640 & 0 & 0 & 91589 & 608916 & 0 & 36609 & 315622 & 1743868 \\
\hline Residual collection & Recycling & 0 & 0 & 0 & 0 & 0 & 0 & 0 & 0 & 0 & 0 & 0 & 0 & 0 & 0 & 0 & 0 & 0 & 0 & 0 & 0 & 0 \\
\hline Recycling & Recycled raw material & 0 & 0 & 0 & 0 & 0 & 0 & 0 & 0 & 2889861 & 0 & 3460557 & 0 & 344545 & 0 & 0 & 1305239 & \begin{tabular}{|l|}
9033916 \\
\end{tabular} & 0 & 1090518 & 9525035 & 27649670 \\
\hline Recycling & Landfill & 88377 & 0 & 0 & 98089 & 102945 & 99009 & 0 & 0 & 196466 & 0 & 0 & 0 & 39139 & 0 & 0 & 89976 & 0 & 0 & 35965 & 310066 & 1060032 \\
\hline Prod_con_w & Prod_con_w & 361443 & 0 & 0 & 401162 & 421022 & 356199 & 0 & 0 & 277544 & 0 & 593040 & 0 & 361965 & 0 & 0 & 220513 & 913330 & 0 & 81050 & 858172 & 4845439 \\
\hline Recycling & Surplus/loss & & & & & & & & & & & & & & & & & & & & & 1548117 \\
\hline
\end{tabular}


S5.9 All initiatives, constant demand (S5b)

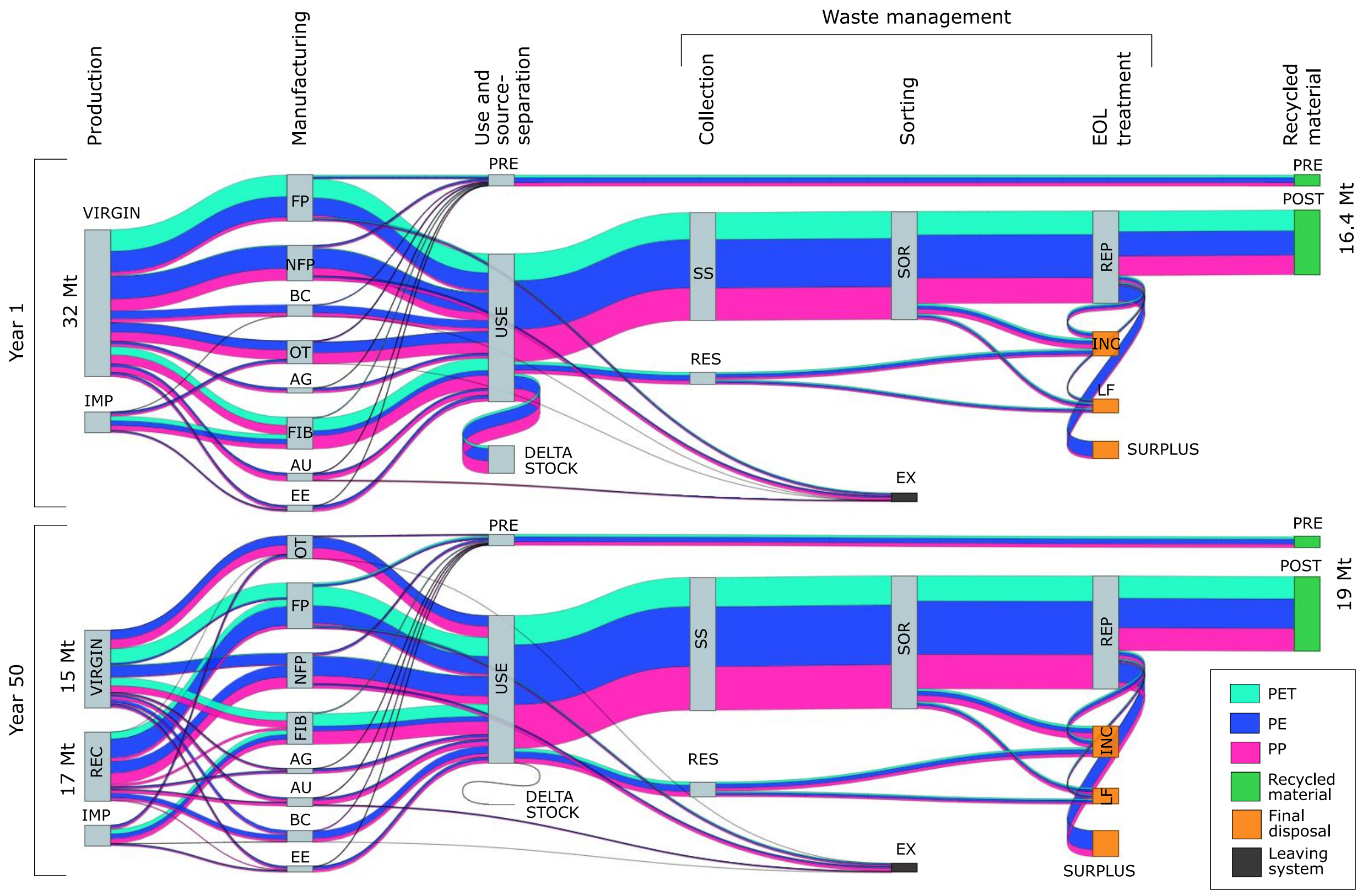

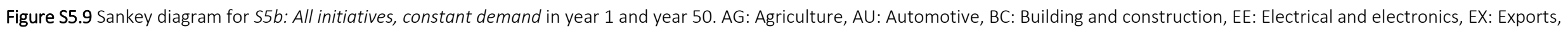

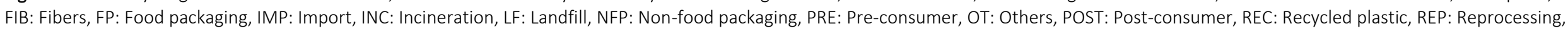
RES: Residual waste, SOR: Sorting, SS: Source-separated waste. 
Table S5.49 Detailed PET flow values [ton] in year 1 in S5b: All initiatives, constant demand. Prod_con_w: Pre-consumer waste. Flow abbreviations are provided in Table S1.1 and on page 53.

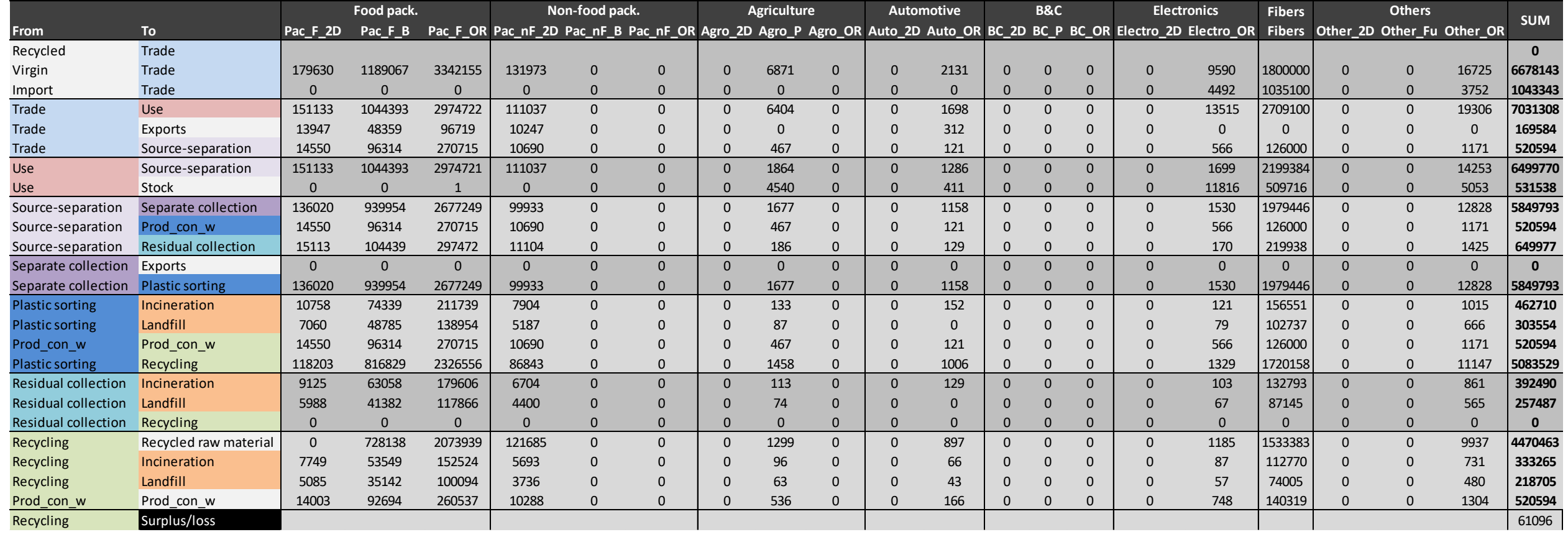

Table S5.50 Detailed PET flow values [ton] in year 50 in S5b: All initiatives, constant demand. Prod_con_w: Pre-consumer waste. Flow abbreviations are provided in Table S1.1 and on page 53.

\begin{tabular}{|c|c|c|c|c|c|c|c|c|c|c|c|c|c|c|c|c|c|c|c|c|c|c|}
\hline From & To & Pac F 2D & $\begin{array}{l}\text { Food pack. } \\
\text { Pac F B }\end{array}$ & Pac F OR & $\begin{array}{r}N \\
\text { Pac nF 2D }\end{array}$ & $\begin{array}{l}\text { on-food pa } \\
\text { Pac nF B }\end{array}$ & $\begin{array}{l}\text { ack. } \\
\text { B Pac nF OR }\end{array}$ & Agro 2D & $\begin{array}{l}\text { Agricultur } \\
\text { Agro P }\end{array}$ & ure & $\begin{array}{l}\text { Auton } \\
\text { Auto 2D }\end{array}$ & $\begin{array}{l}\text { motive } \\
\text { Auto } O R\end{array}$ & BC 2D & $\begin{array}{l}B \& C \\
B C P\end{array}$ & $B C O R$ & $\begin{array}{l}\text { Electr } \\
\text { Electro 2D }\end{array}$ & $\begin{array}{l}\text { ronics } \\
\text { Electro OR }\end{array}$ & \begin{tabular}{|l|} 
Fibers \\
Fibers
\end{tabular} & Other $2 \mathrm{D}$ & $\begin{array}{l}\text { Others } \\
\text { Other Fu }\end{array}$ & Other OR & sum \\
\hline Recycled & Trade & 14003 & 820832 & 2334477 & 131973 & 0 & 0 & 0 & 5000 & 0 & 0 & 1350 & 0 & 0 & 0 & 0 & 9590 & 1800000 & 0 & 0 & 14764 & 5131988 \\
\hline Virgin & Trade & 165627 & 368235 & 1007678 & 0 & 0 & 0 & 0 & 1871 & 0 & 0 & 781 & 0 & 0 & 0 & 0 & 0 & 0 & 0 & 0 & 1962 & 1546155 \\
\hline Import & Trade & 0 & 0 & 0 & 0 & 0 & 0 & 0 & 0 & 0 & 0 & 0 & 0 & 0 & 0 & 0 & 4492 & 1035100 & 0 & 0 & 3752 & 1043343 \\
\hline Trade & Exports & 13947 & 48359 & 96719 & 10247 & 0 & 0 & 0 & 0 & 0 & 0 & 312 & 0 & 0 & 0 & 0 & 0 & 0 & 0 & 0 & 0 & 169584 \\
\hline Trade & Source-separation & 14550 & 96314 & 270715 & 10690 & 0 & 0 & 0 & 467 & 0 & 0 & 121 & 0 & 0 & 0 & 0 & 566 & 126000 & 0 & 0 & 1171 & 520594 \\
\hline Use & Source-separation & 151133 & 1044393 & 2974722 & 111037 & 0 & 0 & 0 & 6404 & 0 & 0 & 1698 & 0 & 0 & 0 & 0 & 13515 & 2709100 & 0 & 0 & 19306 & 7031308 \\
\hline Use & Stock & 0 & 0 & 0 & 0 & 0 & 0 & 0 & 0 & 0 & 0 & 0 & 0 & 0 & 0 & 0 & 0 & 0 & 0 & 0 & 0 & 0 \\
\hline Source-separation & Separate collection & 136020 & 939954 & 2677250 & 99933 & 0 & 0 & 0 & 5763 & 0 & 0 & 1528 & 0 & 0 & 0 & 0 & 12164 & 2438190 & 0 & 0 & 17376 & 6328177 \\
\hline Source-separation & Residual collection & 15113 & 104439 & 297472 & 11104 & 0 & 0 & 0 & 640 & 0 & 0 & 170 & 0 & 0 & 0 & 0 & 1352 & 270910 & 0 & 0 & 1931 & 703131 \\
\hline Separate collection & Exports & 0 & 0 & 0 & 0 & 0 & 0 & 0 & 0 & 0 & 0 & 0 & 0 & 0 & 0 & 0 & 0 & 0 & 0 & 0 & 0 & 0 \\
\hline Separate collection & Plastic sorting & 136020 & 939954 & 2677250 & 99933 & 0 & 0 & 0 & 5763 & 0 & 0 & 1528 & 0 & 0 & 0 & 0 & 12164 & 2438190 & 0 & 0 & 17376 & 6328177 \\
\hline Plastic sorting & Incineration & 10758 & 74339 & 211739 & 7904 & 0 & 0 & 0 & 456 & 0 & 0 & 200 & 0 & 0 & 0 & 0 & 962 & 192832 & 0 & 0 & 1374 & 500564 \\
\hline Plastic sorting & Landfill & 7060 & 48785 & 138954 & 5187 & 0 & 0 & 0 & 299 & 0 & 0 & 0 & 0 & 0 & 0 & 0 & 631 & 126546 & 0 & 0 & 902 & 328364 \\
\hline Prod_con_w & Prod_con_w & 14550 & 96314 & 270715 & 10690 & 0 & 0 & 0 & 467 & 0 & 0 & 121 & 0 & 0 & 0 & 0 & 566 & 126000 & 0 & 0 & 1171 & 520594 \\
\hline Plastic sorting & Recycling & 118203 & 816830 & 2326557 & 86843 & 0 & 0 & 0 & 5008 & 0 & 0 & 1328 & 0 & 0 & 0 & 0 & 10570 & 2118811 & 0 & 0 & 15100 & 5499249 \\
\hline Residual collection & Incineration & 9125 & 63058 & 179606 & 6704 & 0 & 0 & 0 & 387 & 0 & 0 & 170 & 0 & 0 & 0 & 0 & 816 & 163568 & 0 & 0 & 1166 & 424599 \\
\hline Residual collection & Landfill & 5988 & 41382 & 117866 & 4400 & 0 & 0 & 0 & 254 & 0 & 0 & 0 & 0 & 0 & 0 & 0 & 536 & 107342 & 0 & 0 & 765 & 278532 \\
\hline Residual collection & Recycling & 0 & 0 & 0 & 0 & 0 & 0 & 0 & 0 & 0 & 0 & 0 & 0 & 0 & 0 & 0 & 0 & 0 & 0 & 0 & 0 & 0 \\
\hline Recycling & Landfill & 5085 & 35142 & 100094 & 3736 & 0 & 0 & 0 & 215 & 0 & 0 & 57 & 0 & 0 & 0 & 0 & 455 & 91156 & 0 & 0 & 650 & 236590 \\
\hline Prod_con_w & Prod_con_w & 14003 & 92694 & 260537 & 10288 & 0 & 0 & 0 & 536 & 0 & 0 & 166 & 0 & 0 & 0 & 0 & 748 & 140319 & 0 & 0 & 1304 & 520594 \\
\hline Recycling & Surplus/loss & & & & & & & & & & & & & & & & & & & & & 61096 \\
\hline
\end{tabular}




\begin{tabular}{|c|c|c|c|c|c|c|c|c|c|c|c|c|c|c|c|c|c|c|c|c|c|c|}
\hline & & & Food pack. & & & on-food pa & & & gricultur & & & motive & & B\&C & & Electrc & ronics & Fibers & & Others & & SUM \\
\hline From & To & Pac_F_2D & Pac_F_B & Pac_F_OR & Pac_nF_2D & Pac_nf_B & Pac_nF_OR & Agro_2D & Agro_P & Agro_OR & Auto_2 & Auto_OR & BC_2D & BC_P & BC_OR & Electro_2D & Electro_OR & Fibers & Other_2D & Other_Fu & Other_OR & \\
\hline Recycled & Trade & & & & & & & & & & & & & & & & & & & & & 0 \\
\hline Virgin & Trade & 4497128 & 0 & 0 & 2407793 & 2432720 & 118994 & 365360 & 77688 & 60790 & 0 & 517785 & 548048 & 1201236 & 0 & 0 & 421489 & 0 & 0 & 255741 & 1742712 & 14647486 \\
\hline Import & Trade & 0 & 0 & 0 & 0 & 0 & 0 & 0 & 0 & 0 & 0 & 0 & 6579 & 14421 & 0 & 0 & 197000 & 1035100 & 0 & 57378 & 390998 & 1701477 \\
\hline Trade & Use & 3797268 & 0 & 0 & 2033083 & 2104276 & 100476 & 340516 & 72405 & 56656 & 0 & 412484 & 516812 & 1132772 & 0 & 0 & 593621 & 1035100 & 0 & 295217 & 2011721 & 14502408 \\
\hline Trade & Exports & 335593 & 0 & 0 & 179679 & 131394 & 8880 & 0 & 0 & 0 & 0 & 75787 & 0 & 0 & 0 & 0 & 0 & 0 & 0 & 0 & 0 & 731333 \\
\hline Trade & Source-separation & 364267 & 0 & 0 & 195031 & 197050 & 9639 & 24844 & 5283 & 4134 & 0 & 29514 & 37815 & 82885 & 0 & 0 & 24868 & 0 & 0 & 17902 & 121990 & 1115222 \\
\hline Use & Source-separation & \begin{tabular}{|l|}
3797267 \\
\end{tabular} & 0 & 0 & 2033083 & 2104275 & 100476 & 303062 & 65499 & 49178 & 0 & 177242 & 20233 & 45036 & 0 & 0 & 304765 & 840346 & 0 & 237430 & 1679990 & 11757882 \\
\hline Use & Stock & 1 & 0 & 0 & 1 & 1 & 0 & 37454 & 6906 & 7479 & 0 & 235242 & 496579 & 1087736 & 0 & 0 & 288856 & 194754 & 0 & 57787 & 331731 & 2744526 \\
\hline Source-separation & Separate collection & 3417540 & 0 & 0 & 1829774 & 1893848 & 90428 & 272755 & 58949 & 44260 & 0 & 159518 & 18210 & 40532 & 0 & 0 & 274289 & 756312 & 0 & 213687 & 1511991 & 10582094 \\
\hline Source-separation & Residual collection & 379727 & 0 & 0 & 203308 & 210428 & 10048 & 30306 & 6550 & 4918 & 0 & 17724 & 2023 & 4504 & 0 & 0 & 30477 & 84035 & 0 & 23743 & 167999 & 1175788 \\
\hline Separate collection & Exports & 0 & 0 & 0 & 0 & 0 & 0 & 0 & 0 & 0 & 0 & 0 & 0 & 0 & 0 & 0 & 0 & 0 & 0 & 0 & 0 & 0 \\
\hline Separate collection & Plastic sorting & 3417540 & 0 & 0 & 1829774 & 1893848 & 90428 & 272755 & 58949 & 44260 & 0 & 159518 & 18210 & 40532 & 0 & 0 & 274289 & 756312 & 0 & 213687 & 1511991 & 10582094 \\
\hline Plastic sorting & Incineration & 225821 & 0 & 0 & 120906 & 125140 & 5975 & 18023 & 3895 & 2925 & 0 & 17458 & 1443 & 2862 & 0 & 0 & 18124 & 82771 & 0 & 14120 & 99908 & 739369 \\
\hline Plastic sorting & Landfill & 148195 & 0 & 0 & 79345 & 82123 & 3921 & 11827 & 2556 & 1919 & 0 & 0 & 550 & 1574 & 0 & 0 & 11894 & 0 & 0 & 9266 & 65564 & 418735 \\
\hline Prod_con_w & Prod_con_w & 364267 & 0 & 0 & 195031 & 197050 & 9639 & 24844 & 5283 & 4134 & 0 & 29514 & 37815 & 82885 & 0 & 0 & 24868 & 0 & 0 & 17902 & 121990 & 1115222 \\
\hline Plastic sorting & Recycling & 3043525 & 0 & 0 & 1629524 & 1686585 & 80532 & 242905 & 52498 & 39416 & 0 & 142060 & 16217 & 36096 & 0 & 0 & 244271 & 673541 & 0 & 190301 & 1346518 & 9423989 \\
\hline Residual collection & Incineration & 227836 & 0 & 0 & 121985 & 126257 & 6029 & 18184 & 3930 & 2951 & 0 & 15952 & 1465 & 2906 & 0 & 0 & 18286 & 84035 & 0 & 14246 & 100799 & 744859 \\
\hline Residual collection & Landfill & 151891 & 0 & 0 & 81323 & 84171 & 4019 & 12122 & 2620 & 1967 & 0 & 1772 & 558 & 1598 & 0 & 0 & 12191 & 0 & 0 & 9497 & 67200 & 430930 \\
\hline Residual collection & Recycling & 0 & 0 & 0 & 0 & 0 & 0 & 0 & 0 & 0 & 0 & 0 & 0 & 0 & 0 & 0 & 0 & 0 & 0 & 0 & 0 & 0 \\
\hline Recycling & Recycled raw material & 0 & 0 & 0 & 1261353 & 766974 & 0 & 81790 & 47747 & 35849 & 0 & 129204 & 7375 & 16415 & 0 & 0 & 222164 & 612586 & 0 & 275746 & 1879035 & 5336238 \\
\hline Recycling & Landfill & 109136 & 0 & 0 & 58432 & 60478 & 2888 & 8710 & 1882 & 1413 & 0 & 0 & 405 & 1159 & 0 & 0 & 8759 & 0 & 0 & 6824 & 48284 & 308372 \\
\hline Prod_con_w & Prod_con_w & 342400 & 0 & 0 & 183323 & 185221 & 9060 & 27818 & 5915 & 4628 & 0 & 39423 & 41727 & 91459 & 0 & 0 & 32091 & 0 & 0 & 19471 & 132686 & 1115222 \\
\hline Recycling & Surplus/loss & & & & & & & & & & & & & & & & & & & & & 3234881 \\
\hline
\end{tabular}

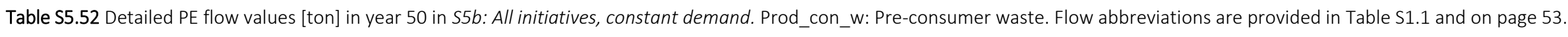

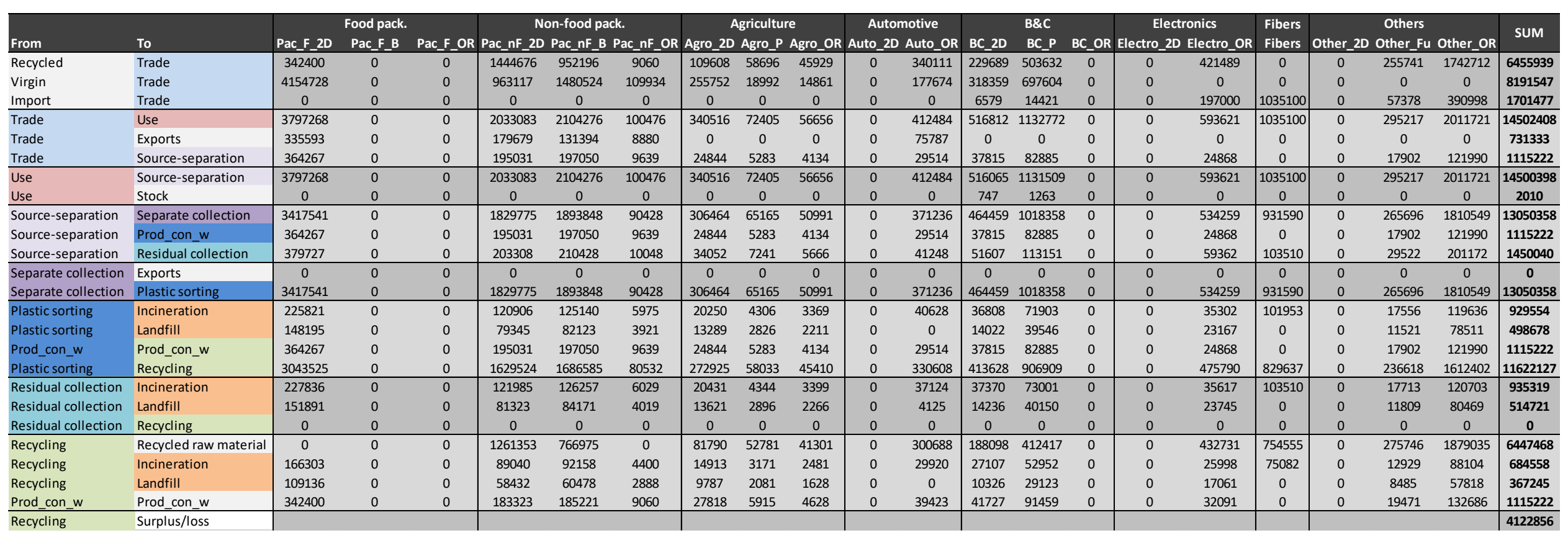




\begin{tabular}{|c|c|c|c|c|c|c|c|c|c|c|c|c|c|c|c|c|c|c|c|c|c|c|}
\hline & & & Food pack. & & & on-food p & & & Agricultur & & & motive & & $B \& C$ & & Electr & ronics & Fibers & & Others & & SUM \\
\hline From & To & Pac_F_2D & Pac_F_B & Pac_F_OR & Pac_nF_2D & Pac_nF_B & Pac_nF_OR & Agro_2D & Agro_P & Agro_OR & Auto_2 & Auto_OR & BC_2D & BC_P & BC_OR & Electro_2D & Electro_OR & Fibers & Other_2D & Other_Fu & Other_OR & \\
\hline Recycled & Trade & & & & & & & & & & & & & & & & & & & & & 0 \\
\hline Virgin & Trade & 791484 & 0 & 0 & 878460 & 921948 & 780000 & 0 & 0 & 607764 & 0 & 1298633 & 0 & 792627 & 0 & 0 & $482876 \quad 2$ & 2000000 & 0 & 177481 & 1879215 & 10610489 \\
\hline Import & Trade & 0 & 0 & 0 & 0 & 0 & 0 & 0 & 0 & 0 & 0 & 0 & 0 & 9000 & 0 & 0 & 226000 & 1035100 & 0 & 39780 & 421200 & 1731080 \\
\hline Trade & Use & 495870 & 0 & 0 & 550361 & 577607 & 581988 & 0 & 0 & 566436 & 0 & 1034611 & 0 & 755936 & 0 & 0 & 680387 & 2895100 & 0 & 244618 & 2168870 & 10551782 \\
\hline Trade & Exports & 231504 & 0 & 0 & 256944 & 269664 & 134832 & 0 & 0 & 0 & 0 & 190000 & 0 & -9000 & 0 & 0 & 0 & 0 & 0 & -39780 & 0 & 1034164 \\
\hline Trade & Source-separation & 64110 & 0 & 0 & 71155 & 74678 & 63180 & 0 & 0 & 41328 & 0 & 74022 & 0 & 54691 & 0 & 0 & 28490 & 140000 & 0 & 12424 & 131545 & 755623 \\
\hline Use & Source-separation & 495870 & 0 & 0 & 550361 & 577606 & 581988 & 295315 & 63852 & 60775 & 0 & 593697 & 0 & 28755 & 0 & 0 & 304786 & 2350388 & 0 & 236279 & 1683565 & 7823237 \\
\hline Use & Stock & 0 & 0 & 0 & 0 & 0 & 0 & -295315 & -63852 & 505660 & 0 & 440914 & 0 & 727180 & 0 & 0 & 375601 & 544712 & 0 & 8339 & 485305 & 2728545 \\
\hline Source-separation & Separate collection & 446283 & 0 & 0 & 495325 & 519846 & 523789 & 265783 & 57467 & 54698 & 0 & 534328 & 0 & 25880 & 0 & 0 & 274307 & 2115349 & 0 & 212651 & 1515208 & 7040913 \\
\hline Source-separation & Residual collection & 49587 & 0 & 0 & 55036 & 57761 & 58199 & 29531 & 6385 & 6078 & 0 & 59370 & 0 & 2876 & 0 & 0 & 30479 & 235039 & 0 & 23628 & 168356 & 782324 \\
\hline Separate collection & Exports & 0 & 0 & 0 & 0 & 0 & 0 & 0 & 0 & 0 & 0 & 0 & 0 & 0 & 0 & 0 & 0 & 0 & 0 & 0 & 0 & 0 \\
\hline Separate collection & Plastic sorting & 446283 & 0 & 0 & 495325 & 519846 & 523789 & 265783 & 57467 & 54698 & 0 & 534328 & 0 & 25880 & 0 & 0 & 274307 & 2115349 & 0 & 212651 & 1515208 & 7040913 \\
\hline Plastic sorting & Incineration & 58391 & 0 & 0 & 64807 & 68015 & 113505 & 34774 & 7519 & 7157 & 0 & 115789 & 0 & 3380 & 0 & 0 & 35890 & 276768 & 0 & 27823 & 198246 & 1012064 \\
\hline Plastic sorting & Landfill & 38319 & 0 & 0 & 42530 & 44635 & 0 & 22821 & 4934 & 4696 & 0 & 0 & 0 & 1796 & 0 & 0 & 23553 & 181629 & 0 & 18259 & 130099 & 513270 \\
\hline Prod_con_w & Prod_con_w & 64110 & 0 & 0 & 71155 & 74678 & 63180 & 0 & 0 & 41328 & 0 & 74022 & 0 & 54691 & 0 & 0 & 28490 & 140000 & 0 & 12424 & 131545 & 755623 \\
\hline Plastic sorting & Recycling & 349573 & 0 & 0 & 387988 & 407195 & 410284 & 208188 & 45014 & 42845 & 0 & 418539 & 0 & 20704 & 0 & 0 & 214865 & 1656953 & 0 & 166570 & 1186863 & 5515579 \\
\hline Residual collection & Incineration & 29752 & 0 & 0 & 33022 & 34656 & 34919 & 17719 & 3831 & 3647 & 0 & 53433 & 0 & 1878 & 0 & 0 & 18287 & 141910 & 0 & 14177 & 101014 & 488245 \\
\hline Residual collection & Landfill & 19835 & 0 & 0 & 22014 & 23104 & 23280 & 11813 & 2554 & 2431 & 0 & 5937 & 0 & 998 & 0 & 0 & 12191 & 93129 & 0 & 9451 & 67343 & 294079 \\
\hline Residual collection & Recycling & 0 & 0 & 0 & 0 & 0 & 0 & 0 & 0 & 0 & 0 & 0 & 0 & 0 & 0 & 0 & 0 & 0 & 0 & 0 & 0 & 0 \\
\hline Recycling & Recycled raw material & 0 & 0 & 0 & 59627 & 0 & 0 & 0 & 0 & 36817 & 0 & 359659 & 0 & 8896 & 0 & 0 & 184638 & 1305121 & 0 & 231978 & 2035042 & 4221778 \\
\hline Recycling & Landfill & 19486 & 0 & 0 & 21627 & 22698 & 22870 & 11610 & 2509 & 2388 & 0 & 0 & 0 & 1010 & 0 & 0 & 11977 & 0 & 0 & 9285 & 66157 & 191616 \\
\hline Prod_con_w & Prod_con_w & 56365 & 0 & 0 & 62559 & 65656 & 55547 & 0 & 0 & 43282 & 0 & 92482 & 0 & 56447 & 0 & 0 & 34388 & 142429 & 0 & 12639 & 133828 & 755623 \\
\hline Recycling & Surplus/loss & & & & & & & & & & & & & & & & & & & & & 517858 \\
\hline
\end{tabular}

Table S5.54 Detailed PP flow values [ton] in year 50 in S5b: All initiatives, constant demand. Prod_con_w: Pre-consumer waste. Flow abbreviations are provided in Table S1.1 and on page 53.

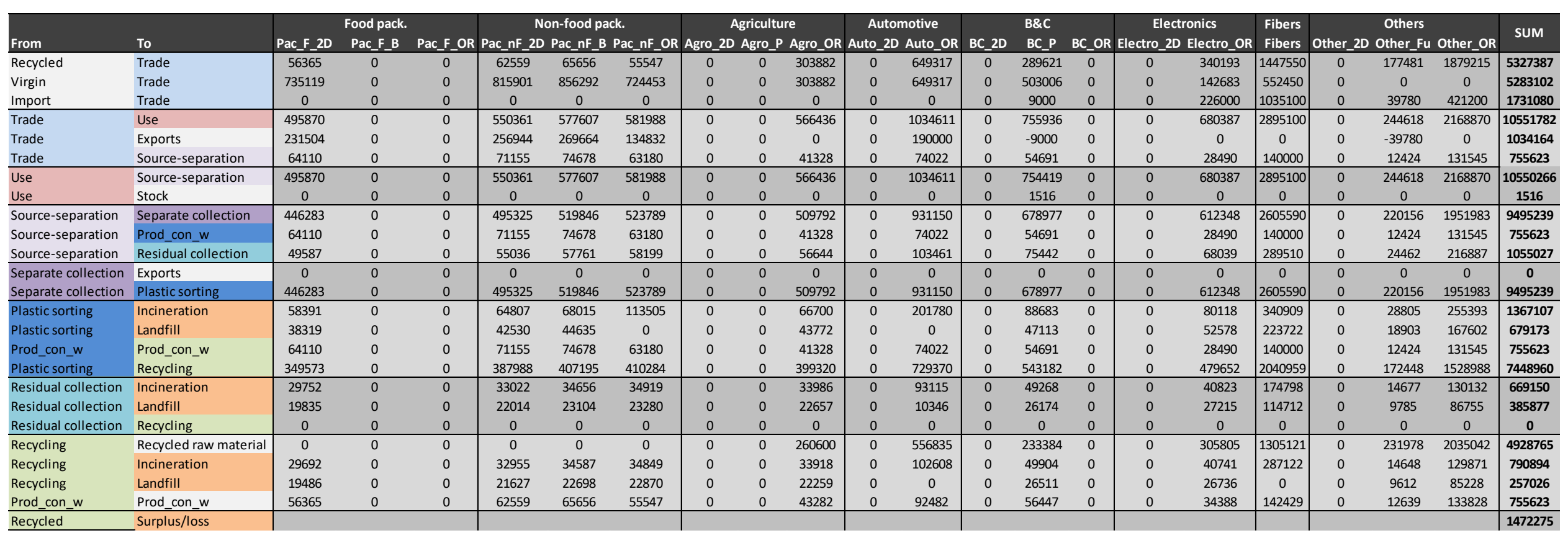




\section{S6 Results: Stock values for SO: Baseline}

Table S6.1 Overview of delta stock and total accumulated quantities in the stock for SO: Baseline [Mt]

\begin{tabular}{|c|c|c|c|c|}
\hline \multirow[b]{2}{*}{ Year } & \multicolumn{2}{|c|}{ Delta stock } & \multicolumn{2}{|c|}{ Total accumulated stock } \\
\hline & {$[\mathrm{Mt}]$} & {$[\mathrm{kg} / \mathrm{cap}]$} & {$[\mathrm{Mt}]$} & [kg/cap] \\
\hline $1(2016)$ & 5.3 & 10.3 & 116 & 228 \\
\hline 2 & 5.4 & 10.5 & 118 & 232 \\
\hline 3 & 5.5 & 10.8 & 121 & 236 \\
\hline 4 & 5.7 & 11.1 & 123 & 241 \\
\hline 5 & 5.8 & 11.3 & 125 & 245 \\
\hline 6 & 5.8 & 11.4 & 127 & 248 \\
\hline 7 & 5.8 & 11.4 & 129 & 252 \\
\hline 8 & 5.8 & 11.4 & 130 & 255 \\
\hline 9 & 5.8 & 11.4 & 132 & 258 \\
\hline 10 & 5.9 & 11.5 & 133 & 261 \\
\hline 11 & 6.0 & 11.7 & 135 & 264 \\
\hline 12 & 6.2 & 12.1 & 136 & 267 \\
\hline 13 & 6.3 & 12.4 & 138 & 270 \\
\hline 14 & 6.6 & 12.9 & 139 & 273 \\
\hline 15 & 6.8 & 13.3 & 141 & 276 \\
\hline 16 & 7.0 & 13.8 & 143 & 280 \\
\hline 17 & 7.3 & 14.2 & 144 & 283 \\
\hline 18 & 7.5 & 14.7 & 146 & 287 \\
\hline 19 & 7.8 & 15.2 & 148 & 290 \\
\hline 20 & 8.0 & 15.7 & 150 & 294 \\
\hline 21 & 8.3 & 16.2 & 152 & 298 \\
\hline 22 & 8.6 & 16.8 & 154 & 302 \\
\hline 23 & 8.9 & 17.4 & 156 & 306 \\
\hline 24 & 9.2 & 18.0 & 158 & 310 \\
\hline 25 & 9.5 & 18.6 & 160 & 315 \\
\hline 26 & 9.8 & 19.3 & 163 & 319 \\
\hline 27 & 10.2 & 20.0 & 165 & 324 \\
\hline 28 & 10.6 & 20.7 & 168 & 329 \\
\hline 29 & 11.0 & 21.5 & 171 & 334 \\
\hline 30 & 11.4 & 22.3 & 173 & 340 \\
\hline 31 & 11.8 & 23.2 & 176 & 346 \\
\hline 32 & 12.3 & 24.1 & 180 & 352 \\
\hline 33 & 12.7 & 25.0 & 183 & 358 \\
\hline 34 & 13.2 & 25.9 & 186 & 365 \\
\hline 35 & 13.8 & 27.0 & 190 & 372 \\
\hline 36 & 14.3 & 28.0 & 194 & 380 \\
\hline 37 & 14.9 & 29.1 & 198 & 388 \\
\hline 38 & 15.4 & 30.3 & 202 & 397 \\
\hline 39 & 16.1 & 31.5 & 207 & 406 \\
\hline 40 & 16.7 & 32.8 & 212 & 416 \\
\hline 41 & 17.4 & 34.1 & 217 & 426 \\
\hline 42 & 18.1 & 35.5 & 223 & 437 \\
\hline 43 & 18.8 & 36.9 & 229 & 449 \\
\hline 44 & 19.6 & 38.4 & 235 & 461 \\
\hline 45 & 20.4 & 40.0 & 242 & 474 \\
\hline 46 & 21.2 & 41.6 & 249 & 489 \\
\hline 47 & 22.1 & 43.3 & 257 & 504 \\
\hline 48 & 23.0 & 45.1 & 265 & 520 \\
\hline 49 & 23.9 & 46.9 & 274 & 537 \\
\hline 50 & 24.9 & 48.8 & 283 & 556 \\
\hline
\end{tabular}


Table S6.1 provides data on the change of stock ( $\Delta$ Stock), as well as how much plastic is accumulating in the stock, for each year, when including data from 1991.

The data suggest that $116 \mathrm{Mt}$, corresponding to $228 \mathrm{~kg} / \mathrm{cap}$ PET, PE and PP, was stored in in-use stocks in 2016. This is slightly lower than what was found for PVC in Europe in $2012{ }^{65}$, and as PVC only accounts for $10 \%$ of European plastic production, and PET, PE and PP accounts for $56 \%^{3}$, this might seem very low. However, despite the considerably smaller quantities of PVC produced in 2016, the quantities of PVC for construction purposes, $3.7 \mathrm{Mt}$, exceeded the quantities of PET, PE and PP produced for construction purposes, $2.5 \mathrm{Mt}^{3}$. As products from the Building and Construction sector are assumed to have the longest lifetime, thereby specifically adding to the stock formation, the estimated stock in 2016 seem reliable.

\section{S7 Results: Combination scenarios with $R C^{\max }=100 \%$}
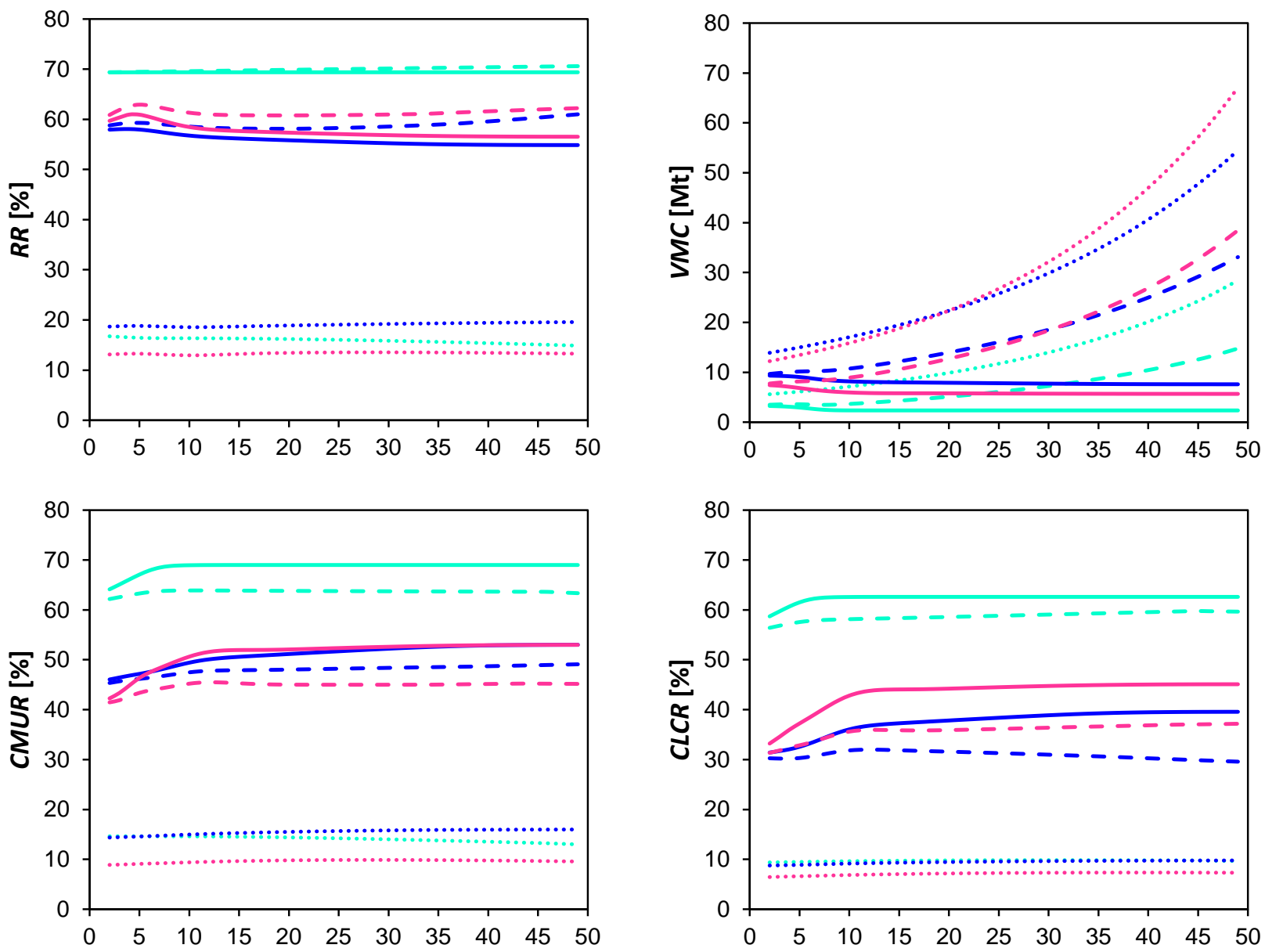

\begin{tabular}{|c|c|c|}
\hline PET: & PE: & PP: \\
\hline - - .S5a: Increasing demand & - - . S5a: Increasing demc & - = - S5a: Increasir \\
\hline $\begin{array}{l}\text { S5b: Constant de } \\
\text { SO:... Baseline }\end{array}$ & $\begin{array}{l}\text { S5b: Constant demand } \\
\text {........ SO: Baseline }\end{array}$ & $\begin{array}{l}\text { S5b: Constan } \\
\ldots . . . . . . .50 \text { SO Baseline }\end{array}$ \\
\hline
\end{tabular}

Figure S7.1 Recycling rate $(R R)$, circular material use rate $(C M U R)$, closed-loop circularity rate $(C L R C)$ and virgin material consumption (VMC) [Mt] of PET, PE and PP for S5a: All initiatives, increasing demand, S5b: All initiatives, constant demand and SO: Baseline. 


\section{S8 References}

1. Eriksen, M. K., Damgaard, A., Boldrin, A. \& Astrup, T. F. T. F. T. F. Quality assessment and circularity potential of recovery systems for household plastic waste. J. Ind. Ecol. 23, 1-13 (2018).

2. Kawecki, D., Scheeder, P. R. W. W. \& Nowack, B. Probabilistic Material Flow Analysis of Seven Commodity Plastics in Europe. Environ. Sci. Technol. 52, 9874-9888 (2018).

3. PlasticsEurope. Plastics - the Facts 2017: Analysis of European plastics production, demand and waste data. 16 (2017). doi:10.1016/j.marpolbul.2013.01.015

4. Van Eygen, E., Laner, D. \& Fellner, J. Circular economy of plastic packaging: Current practice and perspectives in Austria. Waste Manag. 72, 55-64 (2017).

5. PlasticsEurope. Plastics - the Facts 2016 An analysis of European plastics production, demand and waste data. (2016). Available at: https://www.plasticseurope.org/application/files/4315/1310/4805/plastic-the-fact-2016.pdf. (Accessed: 6th September 2019)

6. Faraca, G., Martinez-Sanchez, V. \& Astrup, T. F. Environmental life cycle cost assessment: Recycling of hard plastic waste collected at Danish recycling centres. Resour. Conserv. Recycl. 143, 299-309 (2019).

7. Briassoulis, D. et al. Review, mapping and analysis of the agricultural plastic waste generation and consolidation in Europe. Waste Manag. Res. 31, 1262-1278 (2013).

8. Eriksen, M. K. \& Astrup, T. F. Characterisation of source-separated, rigid plastic waste and evaluation of recycling initiatives: Effects of product design and source-separation system. Waste Manag. 87, 161-172 (2019).

9. Faraca, G. \& Astrup, T. Plastic waste from recycling centres: Characterisation and evaluation of plastic recyclability. Waste Manag. 95, 388-398 (2019).

10. PlasticsEurope. Plastics the Facts 2019 - An analysis of European plastics production, demand and waste data. (2019). Available at: https://www. plasticseurope.org/en/resources/market-data. (Accessed: 4th June 2020)

11. PlasticsEurope. Plastics in Europe: An Analysis of Plastics Consumption and Recovery in Europe 2002 \& 2003. PlasticsEurope 1-20 (2004). doi:10.1109/RAWCON.2002.1030146

12. European Commission. A European Strategy for Plastics in a Circular Economy. Communications of 16.01.2018 (2018).

13. World Economic Forum. the New Plastics Economy- Rethinking the Future of Plastics. 1-120 (2016).

14. Hestin, M., Faninger, T. \& Milios, L. Increased EU Plastics Recycling Targets : Environmental, Economic and Social Impact Assessment. 1-54 (2015).

15. Downey, R. Global Packaging: Sizing Demand and Opportunities for PET Bottles. (2016). Available at: https://www.slideshare.net/Euromonitor/global-packaging-sizing-demand-and-opportunitiesfor-pet-bottles. (Accessed: 24th August 2020) 
16. Euromonitor International. PET Plastic Bottle Consumption Set to Grow by 3.9\% Over the Next Five Years - Packaging Europe. (2017). Available at: https://packagingeurope.com/pet-plastic-bottleconsumption-set-to-grow/. (Accessed: 24th August 2020)

17. Hestin, M. et al. Blueprint for Plastics Packaging Waste: Quality Sorting \& Recycling - Final report. (2017).

18. Future Market Insights. Global Polyester Straps Market Expected to Witness 2.1X Growth in Terms of Value During the Assessment Period 2017 - 2027. (2017). Available at:

https://www.futuremarketinsights.com/press-release/polyester-straps-market. (Accessed: 27th August 2020)

19. Plastic Recyclers Europe. Technical Plastic Parts Strategy Paper - The Way Ahead for Automotive and Electrical and Electronic Plastics Waste. (2020). Available at: https://743c8380-22c6-44579895-11872f2a708a.filesusr.com/ugd/dda42a_6644d71e69704a33afe012418e159094.pdf. (Accessed: 21st August 2020)

20. PlasticsToday. Plastics use in vehicles to grow $75 \%$ by 2020 , says industry watcher. (2015). Available at: https://www.plasticstoday.com/automotive-and-mobility/plastics-use-vehicles-grow75-2020-says-industry-watcher. (Accessed: 21st August 2020)

21. Wrap. UK Plastics Waste-A review of supplies for recycling, global market demand, future trends and associated risks. (2006).

22. Statista. Chemical fiber global production by type 2000-2018 | Statista. (2020). Available at: https://www.statista.com/statistics/271651/global-production-of-the-chemical-fiber-industry/. (Accessed: 27th August 2020)

23. Geyer, R., Jambeck, J. R. \& Law, K. L. Production, use, and fate of all plastics ever made. Sci. Adv. 3, 1-5 (2017).

24. PlasticsEurope. Publications. (2020). Available at: https://www.plasticseurope.org/en/resources/publications. (Accessed: 31st August 2020)

25. Eriksen, M. K., Christiansen, J. D., Daugaard, A. E. \& Astrup, T. F. Closing the loop for PET, PE and PP waste from households: Influence of material properties and product design for plastic recycling. Waste Manag. 96, 75-85 (2019).

26. Petcore Europe. 2017 Survey on European PET Recycle Industry - $58.2 \%$ of PET bottles collected. (2018). Available at: https://petcore-europe.prezly.com/2017-survey-on-european-pet-recycleindustry-582--of-pet-bottles-collected. (Accessed: 4th June 2020)

27. Dansk Retursystem. Closed loop: Brug materialerne igen og igen - danskretursystem.dk. (2020). Available at: https://danskretursystem.dk/miljoe-viden/closed-loop-brug-materialerne-igen-ogigen/. (Accessed: 13th August 2020)

28. Ragaert, K., Delva, L. \& Geem, K. Van. Mechanical and chemical recycling of solid plastic waste. Waste Manag. 69, 24-58 (2017).

29. Briassoulis, D., Hiskakis, M. \& Babou, E. Technical specifications for mechanical recycling of agricultural plastic waste. Waste Manag. 33, 1516-1530 (2013).

30. AmericaRecyclesDay. Plastic Bag \& Film Recycling. (2012). Available at: 
https://www.youtube.com/watch?v=7zEBEXPB4c0. (Accessed: 21st August 2020)

31. Earth911TV. How Plastic Bags Get Recycled - YouTube. Hilec Poly plant, North Vernon, Indianan, USA (2011). Available at: https://www.youtube.com/watch?v=Q6hzhKmw4EY. (Accessed: 21st August 2020)

32. Huysman, S., De Schaepmeester, J., Ragaert, K., Dewulf, J. \& De Meester, S. Performance indicators for a circular economy: A case study on post-industrial plastic waste. Resour. Conserv. Recycl. 120, 46-54 (2017).

33. Teknologisk Institut. Ekstruderingsvirksomhed omdanner plastaffald til nye produkter - Ydelser Teknologisk Institut. (2020). Available at: https://www.teknologisk.dk/ydelser/ekstruderingsvirksomhed-omdanner-plastaffald-til-nyeprodukter/39946. (Accessed: 21st August 2020)

34. Sari, P. S., Sharika, T., Bicy, K. \& Thomas, S. Recycling of Polyolefin Materials. in Polyolefin Compounds and Materials (eds. Al-Ali AlMa'adeed, M. \& Krupa, I.) 315-339 (Springer International Publishing, 2016). doi:10.1007/978-3-319-25982-6_13

35. European Food Safety Authority. Register of Questions. Unit filter: Food ingredients and packaging, key-word: Recycling (2020). Available at: http://registerofquestions.efsa.europa.eu/roqFrontend/ListOfQuestionsNoLogin?2. (Accessed: 13th August 2020)

36. Kozlowski, M. Recycling of Food Packaging Materials. in Functional Polymers in Food Science 355399 (John Wiley \& Sons, Inc., 2015). doi:10.1002/9781119109785.ch11

37. Rieckmann, T., Frei, F. \& Völker, S. Modelling of PET Quality Parameters for a Closed-Loop Recycling System for Food Contact. Macromol. Symp. 302, 34-45 (2011).

38. Welle, F. The Facts about PET. (2018).

39. Lynggaard, T. \& Anders, H. B. Personal communication with Færch Plast - 17/01/2019. (2019).

40. British Plastic Federation. Recycled content used in plastic packaging applications. (2020). Available at: https://www.fdf.org.uk/publicgeneral/recycled-content-used-plastic-packagingapplications.pdf. (Accessed: 18th August 2020)

41. MOSCA. Sustainability \& Resources: Strap Production. (2020). Available at: https://www.mosca.com/en-en/company/strap-production/sustainability-resources/. (Accessed: 18th August 2020)

42. PETcore Europe. Recycled Products. (2020). Available at: https://www.petcoreeurope.org/recycled-products.html. (Accessed: 18th August 2020)

43. Eriksen, M. K., Pivnenko, K., Olsson, M. E. E. \& Astrup, T. F. F. Contamination in plastic recycling: Influence of metals on the quality of reprocessed plastic. Waste Manag. 79, 595-606 (2018).

44. Unilever. Dove moves to $100 \%$ recycled plastic bottles. (2019). Available at: https://www.unilever.com/news/news-and-features/Feature-article/2019/dove-moves-to-100per-cent-recycled-plastic-bottles.html. (Accessed: 18th August 2020)

45. Unilever. Rethinking plastic packaging - towards a circular economy | Sustainable Living | Unilever 
global company website. (2020). Available at: https://www.unilever.com/sustainableliving/reducing-environmental-impact/waste-and-packaging/rethinking-plastic-packaging/.

(Accessed: 18th August 2020)

46. CalRecycle. Ban on Single-Use Carryout Bags (SB 270 / Proposition 67) Frequently Asked Questions (revised April 2017). (2017). Available at: https://www.calrecycle.ca.gov/plastics/carryoutbags/faq. (Accessed: 18th August 2020)

47. Novolex. Recycled Content in Our Bags . (2015). Available at: https://accutechfilms.com/news/recycled-content-in-our-bags/. (Accessed: 18th August 2020)

48. Leblanck, R. An Introduction to Polypropylene Recycling. (2019). Available at: https://www.thebalancesmb.com/an-overview-of-polypropylene-recycling-2877863. (Accessed: 18th August 2020)

49. ACEA. The Automobile Industry Pocket Guide. European Automobile Manufacturer's Association (ACEA). (2017).

50. Rouilloux, G. Plastics. The future for automakers and chemical companies - - Article - Kearney. (2020). Available at: https://www.kearney.com/chemicals/article?/a/plastics-the-future-forautomakers-and-chemical-companies. (Accessed: 10th September 2020)

51. Conversio. Processing residues from five industrial sectors (personal communication). Conversio Market \& Strategy GmbH. (2017).

52. Clarke, C., Williams, I. D. \& Turner, D. A. Evaluating the carbon footprint of WEEE management in the UK. Resour. Conserv. Recycl. 141, 465-473 (2019).

53. PlastEurope. AGRICULTURAL FILMS RECYCLING: European Parliament's draft report on fertilising products / Potential to create distortions in mulch films market. (2017). Available at: https://www.plasteurope.com/news/AGRICULTURAL_FILMS_RECYCLING_t238095/. (Accessed: 10th September 2020)

54. Tojo, N., Kogg, B., Kiørboe, N., Kjær, B. \& Aalto, K. Prevention of Textile Waste Material flows of textiles in three Nordic countries and suggestions on policy instruments. (2012).

doi:10.6027/TN2012-545

55. UM Comtrade. United Nations Comtrade Database - International Trade Statistics - Import/Export Data. New York, United States. (2016).

56. Faraca, G., Edjabou, V. M., Boldrin, A. \& Astrup, T. Combustible waste collected at Danish recycling centres: Characterisation, recycling potentials and contribution to environmental savings. Waste Manag. 89, 354-365 (2019).

57. Eurostat. How much plastic packaging waste do we recycle? (2019). Available at: https://ec.europa.eu/eurostat/web/products-eurostat-news/-/DDN-20191105-2. (Accessed: 7th September 2020)

58. PlasticsEurope. Automotives 2013.

59. Fiore, S., Ruffino, B. \& Zanetti, M. C. Automobile Shredder Residues in Italy: Characterization and valorization opportunities. Waste Manag. 32, 1548-1559 (2012). 
60. PlasticsEurope. Overview Plastic Waste from Building \& Construction by Polymer and by Recycling, Energy Recovery and Disposal. (2017). Available at:

https://www.plasticseurope.org/application/files/2715/1714/0155/BuildingConstruction_plasticse urope_report_23012017.pdf. (Accessed: 21st August 2020)

61. Nordin, H. L. et al. Kartläggning av plastflöden i Sverige. (2019).

62. Buekens, A. \& Yang, J. Recycling of WEEE plastics: A review. J. Mater. Cycles Waste Manag. 16, 415-434 (2014).

63. COWI. Forsøg på nyt testsorteringsanlæg for kildesorterede/kildeopdelte materialer. (2017).

64. Haupt, M., Waser, E., Würmli, J. C. C. \& Hellweg, S. Is there an environmentally optimal separate collection rate? Waste Manag. 77, 220-224 (2018).

65. Ciacci, L., Passarini, F. \& Vassura, I. The European PVC cycle: In-use stock and flows. Resour. Conserv. Recycl. 123, 108-116 (2017). 